Prepared in cooperation with the City of Philadelphia, Water Department

Determination of Time-of-Travel, Dispersion Characteristics, and Oxygen Reaeration Coefficients during Low Streamflows: Lower Tacony/Frankford Creek, Philadelphia, Pennsylvania
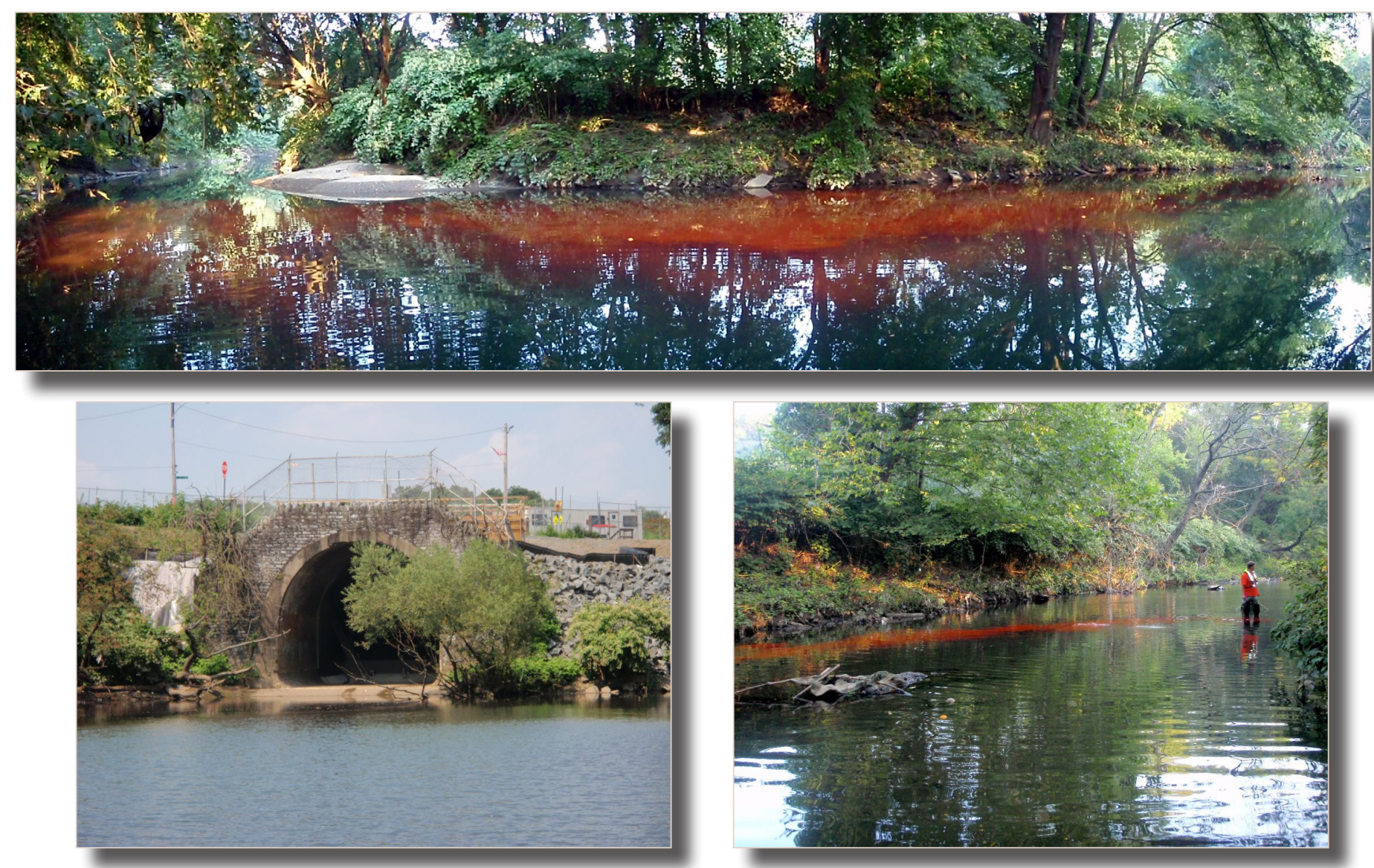

Scientific Investigations Report 2010-5195 


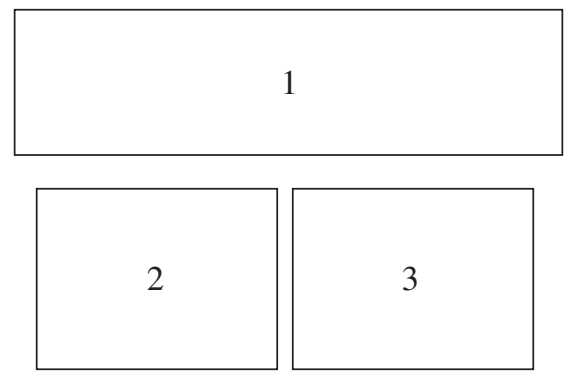

\section{Cover.}

1. View of dye traveling downstream from injection location on Tacony/Frankford Creek, Philadelphia, Pa., on August 18, 2009.

2. Outlet of T14 combined sewer overflow (CSO) at confluence of the former Wingohocking Creek with Frankford Creek, Philadelphia, Pa., on August 18, 2009.

3. Dye injection and propane gas diffusers at injection location on Tacony/Frankford Creek, Philadelphia, Pa., on August 18, 2009.

Photographs by Jason Cruz, Philadelphia Water Department, August 18, 2009.

\section{Back cover:}

Looking downstream at sampling site TAC0263, where dye is traveling along the right bank of the stream, Frankford Creek, Philadelphia, Pa., on August 20, 2009. Debris in trees upstream from exposed bedrock on the right bank marks recent high streamflow. 


\section{Determination of Time-of-Travel, Dispersion Characteristics, and Oxygen Reaeration Coefficients During Low Streamflows: Lower Tacony/Frankford Creek, Philadelphia, Pennsylvania}

By Lisa A. Senior and Matthew C. Gyves

Prepared in cooperation with the City of Philadelphia, Water Department

Scientific Investigations Report 2010-5195 


\section{U.S. Department of the Interior \\ KEN SALAZAR, Secretary \\ U.S. Geological Survey \\ Marcia K. McNutt, Director}

U.S. Geological Survey, Reston, Virginia: 2010

For more information on the USGS - the Federal source for science about the Earth, its natural and living resources, natural hazards, and the environment, visit http://www.usgs.gov or call 1-888-ASK-USGS

For an overview of USGS information products, including maps, imagery, and publications, visit http://www.usgs.gov/pubprod

To order this and other USGS information products, visit http://store.usgs.gov

Any use of trade, product, or firm names is for descriptive purposes only and does not imply endorsement by the U.S. Government.

Although this report is in the public domain, permission must be secured from the individual copyright owners to reproduce any copyrighted materials contained within this report.

Suggested citation:

Senior, L.A., and Gyves, M.C., 2010, Determination of time-of-travel, dispersion characteristics, and oxygen reaeration coefficients during low streamflows - Lower Tacony/Frankford Creek, Philadelphia, Pennsylvania: U.S. Geological Survey Scientific Investigations Report 2010-5195, 90 p. 


\section{Contents}

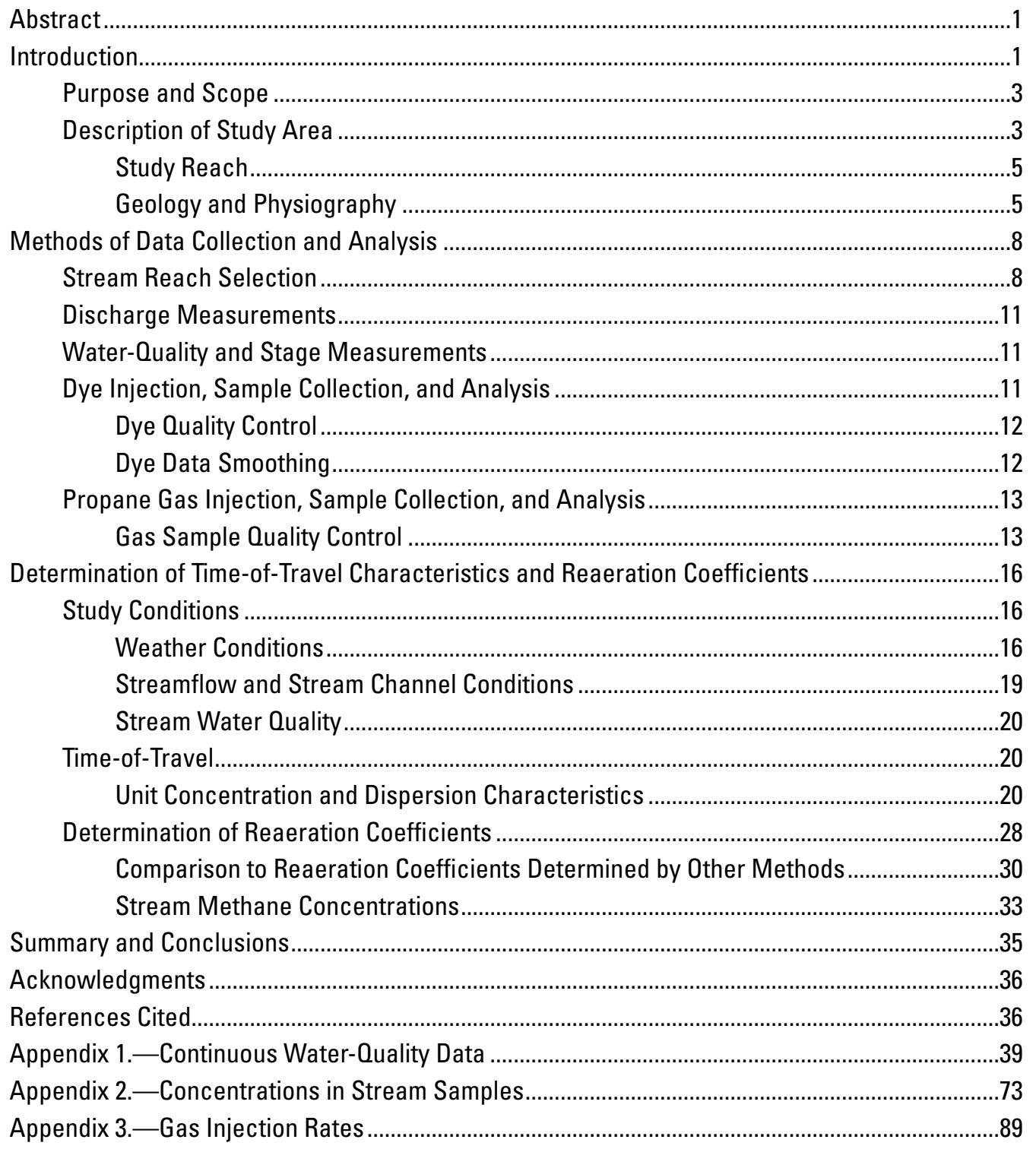




\section{Figures}

1. Map showing location of Tacony/Frankford Creek, adjacent park land, combined sewer overflows (CSOs), selected streamgages, and underlying geologic units in and near Philadelphia, Pennsylvania...

2. Aerial photograph showing study reach of Tacony/Frankford Creek and estimated location of nearby buried stream valleys in Philadelphia, $\mathrm{Pa}$.....

3. Photographs showing backwater conditions in Frankford Creek at the dam in the Juniata Golf Course, Philadelphia, $\mathrm{Pa}$., $(A)$ when the dam notch was open on July 18,2009 , and $(B)$ when the dam notch was completely blocked on August 18, 2009.......7

4. Aerial photograph showing configuration of gravel bar at outlet of pool below T14 combined sewer overflow outfall on Tacony/Frankford Creek, Philadelphia, Pa., 2008

5. Photograph showing dye injection and propane gas diffusion on September 3, 2009, in Tacony/Frankford Creek near U.S. Route 1, Philadelphia, $\mathrm{Pa}$

6. Diagram $(A)$ and photograph $(B)$ of the gas sampler used to collect stream samples for gas analysis in the reaeration study on Tacony/Frankford Creek, Philadelphia, Pa., 2009.

7. Graphs showing methane concentrations in relation to propane concentrations in stream samples at each site sampled on (A) August 18, 2009; (B) September 1, 2009; and (C) September 3, 2009

8. Graphs showing wind speed, wind direction, air temperature, and barometric pressure recorded at the Philadelphia International Airport during study periods on (A) August 18, (B) September 1, and (C) September 3, 2009.

9. Graphs showing stream discharge $(A)$ and specific conductance $(B)$ at streamgage 01467087, Frankford Creek at Castor Avenue, Philadelphia, Pa., August 10 through September 10, 2009.

10. Graphs showing stream temperatures and concentrations of dissolved oxygen measured by water-quality sondes at sampling sites in Tacony/Frankford Creek, Philadelphia, Pa., on (A) August 18, 2009; (B) September 1, 2009; and (C) September 3, 2009.

11. Graph showing dye and propane concentrations in relation to time since dye injection at five stream sites on Tacony/Frankford Creek, Philadelphia, Pa., August 18, 2009.

12. Graph showing dye and propane gas concentrations in relation to time since dye injection at three stream sites on Tacony/Frankford Creek, Philadelphia, $\mathrm{Pa}$., September 1, 2009

13. Graph showing dye and propane gas concentrations in relation to time since dye injection at three stream sites on Tacony/Frankford Creek, Philadelphia, Pa., September 3, 2009

14. Graphs showing traveltime of dye cloud in relation to distance from injection in Tacony/Frankford Creek, Philadelphia, Pa., for $(A)$ lower sub-reach from above T14 pool to below T14 pool on August 18, 2009; (B) lower sub-reach from below T14 pool to streamgage at Castor Avenue on September 1, 2009; and (C) upper reach from Route 1 to T14 pool on September 3, 2009.

15. Graph showing unit-peak concentration in relation to time elapsed since dye injection at selected sampling sites, Tacony/Frankford Creek, Philadelphia, Pa., during dye study conducted on August 18, September 1, and September 3, 2009

16. Graphs showing concentrations of propane and methane in stream samples collected at sites in Tacony/Frankford Creek, Philadelphia, Pa., on (A) August 18, (B) September 1, and (C) September 3, 2009.

17. Graph showing average methane concentrations in samples collected at three sites on Tacony/Frankford Creek, Philadelphia, Pa., in both August and September 2009... 


\section{Tables}

1. Sample and injection sites for the time-of-travel and reaeration study of Tacony/Frankford Creek, Philadelphia, Pa., August-September 2009...

2. Stream discharge measured at sites in study reaches, Tacony/Frankford Creek, Philadelphia, Pa., on August 18, September 1, and September 3, 2009.

3. Minimum, maximum, and mean hourly air temperature, wind speed, wind direction, and barometric pressure recorded at the Philadelphia International Airport during study periods on August 18, September 1, and September 3, 2009

4. Mass of dye injected into, and measured at, downstream sites on Tacony/Frankford Creek, Philadelphia, Pa., on August 18, September 1, and September 3, 2009.

5. Summary of time-of-travel characteristics calculated at mid-flowline for dye injected into three reaches of Tacony/Frankford Creek, Philadelphia, Pa., on August 18, September 1, and September 3, 2009

6. Reaeration coefficients determined from field method (constant rate injection of tracer gas) for study sub-reaches in Tacony/Frankford Creek, Philadelphia, Pa., on August 18, September 1, and September 3, 2009

7. Comparison of reaeration coefficients (K2) calculated by theoretical equations based on stream characteristics and coefficients determined by field methods using tracer gases for sub-reaches of Tacony/Frankford Creek, Philadelphia, Pa., August and September 2009

8. Comparison of reaeration coefficients (K2) calculated by time offset of maximum dissolved oxygen method (McBride, 2002) and coefficients determined by field methods using tracer gases, Tacony/Frankford Creek, Philadelphia, Pa., August and September 2009 results 


\section{Conversion Factors and Abbreviations}

\begin{tabular}{|c|c|c|}
\hline Multiply & By & To obtain \\
\hline \multicolumn{3}{|c|}{ Length } \\
\hline inch (in.) & 2.54 & centimeter $(\mathrm{cm})$ \\
\hline inch (in.) & 25.4 & millimeter $(\mathrm{mm})$ \\
\hline foot $(\mathrm{ft})$ & 0.3048 & meter $(\mathrm{m})$ \\
\hline mile (mi) & 1.609 & kilometer $(\mathrm{km})$ \\
\hline \multicolumn{3}{|c|}{ Area } \\
\hline acre & 4,047 & square meter $\left(\mathrm{m}^{2}\right)$ \\
\hline acre & 0.4047 & hectare (ha) \\
\hline acre & 0.004047 & square kilometer $\left(\mathrm{km}^{2}\right)$ \\
\hline square foot $\left(\mathrm{ft}^{2}\right)$ & 929.0 & square centimeter $\left(\mathrm{cm}^{2}\right)$ \\
\hline square foot $\left(\mathrm{ft}^{2}\right)$ & 0.09290 & square meter $\left(\mathrm{m}^{2}\right)$ \\
\hline square mile $\left(\mathrm{mi}^{2}\right)$ & 259.0 & hectare (ha) \\
\hline square mile $\left(\mathrm{mi}^{2}\right)$ & 2.590 & square kilometer $\left(\mathrm{km}^{2}\right)$ \\
\hline \multicolumn{3}{|c|}{ Volume } \\
\hline gallon (gal) & 3.785 & liter $(\mathrm{L})$ \\
\hline gallon (gal) & 0.003785 & cubic meter $\left(\mathrm{m}^{3}\right)$ \\
\hline million gallons (Mgal) & 3,785 & cubic meter $\left(\mathrm{m}^{3}\right)$ \\
\hline cubic inch $\left(\mathrm{in}^{3}\right)$ & 0.01639 & liter (L) \\
\hline cubic foot $\left(\mathrm{ft}^{3}\right)$ & 28.32 & cubic decimeter $\left(\mathrm{dm}^{3}\right)$ \\
\hline cubic foot $\left(\mathrm{ft}^{3}\right)$ & 0.02832 & cubic meter $\left(\mathrm{m}^{3}\right)$ \\
\hline cubic yard $\left(\mathrm{yd}^{3}\right)$ & 0.7646 & cubic meter $\left(\mathrm{m}^{3}\right)$ \\
\hline acre-foot (acre-ft) & 0.001233 & cubic hectometer $\left(\mathrm{hm}^{3}\right)$ \\
\hline \multicolumn{3}{|c|}{ Flow rate } \\
\hline foot per second (ft/s) & 0.3048 & meter per second $(\mathrm{m} / \mathrm{s})$ \\
\hline cubic foot per second $\left(\mathrm{ft}^{3} / \mathrm{s}\right)$ & 0.02832 & cubic meter per second $\left(\mathrm{m}^{3} / \mathrm{s}\right)$ \\
\hline $\begin{array}{l}\text { cubic foot per second per square } \\
\text { mile }\left[\left(\mathrm{ft}^{3} / \mathrm{s}\right) / \mathrm{mi}^{2}\right]\end{array}$ & 0.01093 & $\begin{array}{l}\text { cubic meter per second per square } \\
\text { kilometer }\left[\left(\mathrm{m}^{3} / \mathrm{s}\right) / \mathrm{km}^{2}\right]\end{array}$ \\
\hline cubic foot per day $\left(\mathrm{ft}^{3} / \mathrm{d}\right)$ & 0.02832 & cubic meter per day $\left(\mathrm{m}^{3} / \mathrm{d}\right)$ \\
\hline gallon per minute (gal/min) & 0.06309 & liter per second $(\mathrm{L} / \mathrm{s})$ \\
\hline inch per year (in/yr) & 25.4 & millimeter per year $(\mathrm{mm} / \mathrm{yr})$ \\
\hline mile per hour $(\mathrm{mi} / \mathrm{h})$ & 1.609 & kilometer per hour $(\mathrm{km} / \mathrm{h})$ \\
\hline \multicolumn{3}{|c|}{ Mass } \\
\hline ounce, avoirdupois (oz) & 28.35 & gram $(\mathrm{g})$ \\
\hline pound, avoirdupois (lb) & 0.4536 & kilogram (kg) \\
\hline
\end{tabular}

Temperature in degrees Celsius $\left({ }^{\circ} \mathrm{C}\right)$ may be converted to degrees Fahrenheit $\left({ }^{\circ} \mathrm{F}\right)$ as follows:

$$
{ }^{\circ} \mathrm{F}=\left(1.8 \mathrm{x}^{\circ} \mathrm{C}\right)+32
$$

Temperature in degrees Fahrenheit $\left({ }^{\circ} \mathrm{F}\right)$ may be converted to degrees Celsius $\left({ }^{\circ} \mathrm{C}\right)$ as follows:

$$
{ }^{\circ} \mathrm{C}=\left({ }^{\circ} \mathrm{F}-32\right) / 1.8
$$

Vertical coordinate information is referenced to North American Vertical Datum of 1988 (NAVD 88) except where noted in text as referenced to National Geodetic Vertical Datum of 1929 (NGVD 29).

Horizontal coordinate information is referenced to North American Datum of 1983 (NAD 83).

Elevation, as used in this report, refers to distance above the vertical datum.

Specific conductance is given in microsiemens per centimeter at 25 degrees Celsius $\left(\mu \mathrm{S} / \mathrm{cm}\right.$ at $\left.25^{\circ} \mathrm{C}\right)$.

Concentrations of chemical constituents in water are given either in milligrams per liter (mg/L) or micrograms per liter $(\mu \mathrm{g} / \mathrm{L})$. 


\title{
Determination of Time-of-Travel, Dispersion Characteristics, and Oxygen Reaeration Coefficients during Low Streamflows: Lower Tacony/Frankford Creek, Philadelphia, Pennsylvania
}

\author{
By Lisa A. Senior and Matthew C. Gyves
}

\section{Abstract}

Time-of-travel, dispersion characteristics, and oxygen reaeration coefficients were determined by use of dye and gas tracing for a 2-mile reach of Tacony/Frankford Creek in Philadelphia, southeastern Pennsylvania. The reach frequently has concentrations of dissolved oxygen (DO) below the waterquality standard of 4 milligrams per liter during warm months. Several large combined sewer overflows (CSOs), including one of the largest in Philadelphia (former Wingohocking Creek), discharge to the study reach in this urbanized watershed, affecting water quality and the timing and magnitude of storm peaks. In addition, a dam that commonly results in backwater conditions and reduced natural reaeration is present a few hundred feet from the end of the study reach. Time-oftravel and reaeration data were collected under base-flow conditions in August and September 2009 for three sub-reaches from Roosevelt Boulevard (U.S. Route 1) to Castor Avenue.

Determination of traveltimes to the centroid of the dye cloud were needed for calculation of the reaeration coefficients. Results of the dye study in Tacony/Frankford Creek indicate that traveltimes were affected by the presence of man-made structures, such as the large pool developed at the outfall of the T14 CSO and the dam, both of which reduce stream velocities. Mean stream velocities during the dye-tracer tests ranged from 0.04 to 0.39 foot per second in sub-reaches. The dispersion efficiency of the stream was determined from relations between normalized unit concentrations and time to peak for use in water-quality modeling.

Oxygen reaeration coefficients determined by a constant rate-injection method using propane as the tracer gas were as low as 0.04 unit per hour in a long pool affected by backwater conditions behind a dam. The highest reaeration coefficient was 2.29 units per hour for a steep-gradient sub-reach with multiple winding channels through gravel deposits, just downstream of a large pool developed at the outlet of the T14 CSO. Reaeration coefficients determined from the field tracergas method were compared to values calculated by two other methods, one that is based on theoretical equations using physical properties of the stream as variables and the other that is based on equations using the timing of measured daily maximum DO concentrations in the stream. Reaeration coefficients from the two alternate methods were most similar to values determined from the field tracer-gas method for the upstream portion of the study reach, characterized by free-flowing riffle and pools. Reaeration coefficients determined by the tracer-gas method were 2 to 10 times higher than coefficients determined by two alternate methods for most sub-reaches hydraulically affected by man-made structures.

In addition to the tracer gas, propane, the gas analysis also included methane, ethane, and ethene, of which only methane was measured in concentrations above a few micrograms per liter. Methane, thought to occur naturally or because of ongoing processes in the stream, was measured in concentrations ranging from 6.6 to 78 micrograms per liter; the concentrations were greatest in sub-reaches dominated by pools.

\section{Introduction}

The city of Philadelphia, through the Philadelphia Water Department (PWD), is investigating chronic low dissolvedoxygen (DO) conditions in Tacony/Frankford Creek, a minor tributary of the Delaware River in southeast Pennsylvania (fig. 1). Numerous combined sewer overflows (CSOs) discharge to the creek in Philadelphia, affecting stream water quality, and are likely factors in causing low DO concentrations. One of the largest CSOs in the city is at the mouth of a former tributary to Tacony/Frankford Creek named Wingohocking Creek, which has been buried and channelized since the early $20^{\text {th }}$ century.

Concentrations of DO lower than the Pennsylvania waterquality criterion of an instantaneous minimum of $4.0 \mathrm{mg} / \mathrm{L}$ for the designated use of warm-water fishes (Pennsylvania Department of Environmental Protection, 2009) have been documented in the Tacony/Frankford Creek (Jason Cruz, Philadelphia Water Dept., written commun., Feb. 9, 2009). DO in streams such as Tacony/Frankford Creek is consumed in the water column by biochemical oxygen demand (BOD), sediment oxygen demand (SOD), and metabolism of algae 

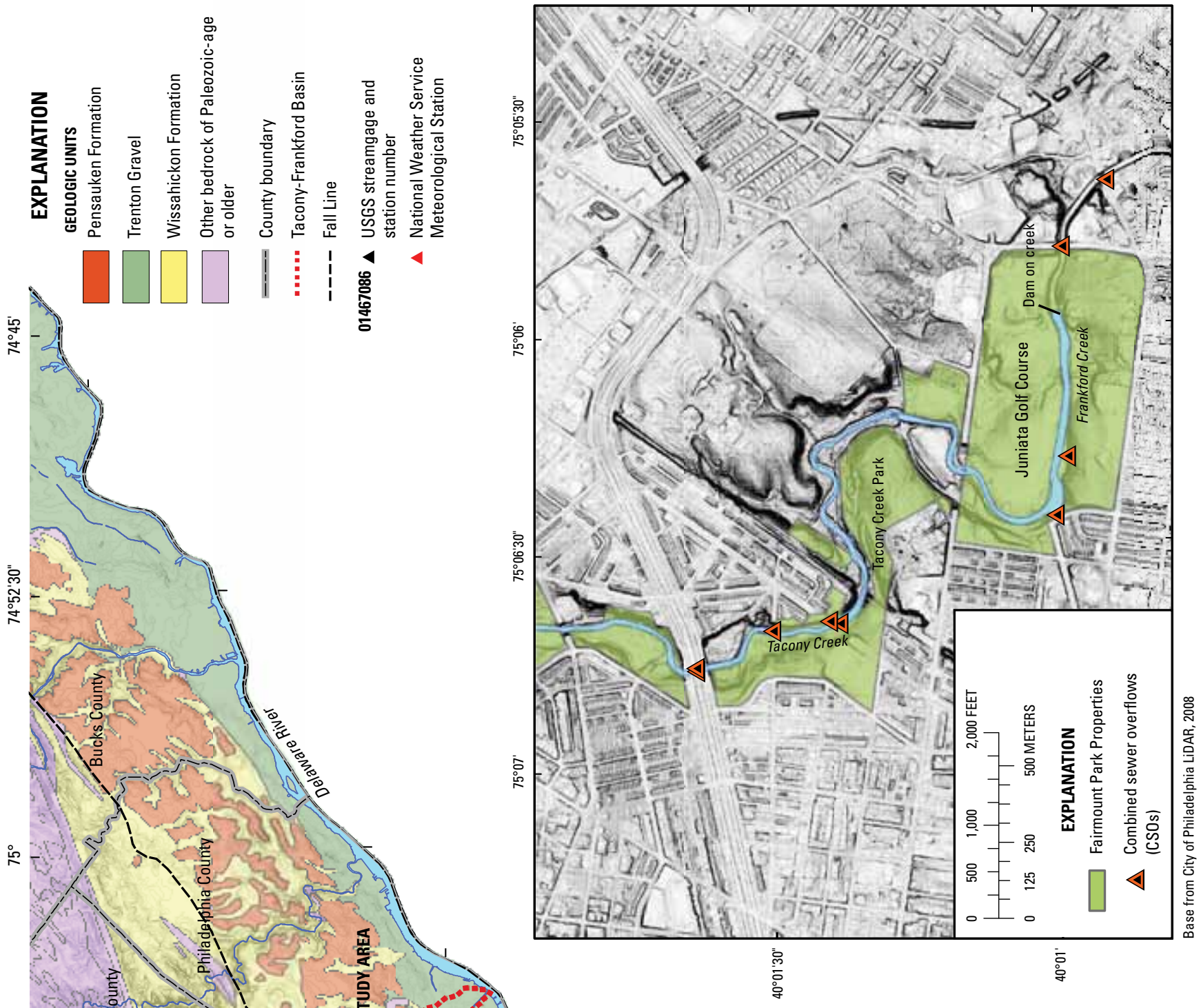

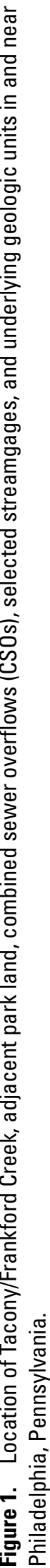


and heterotrophic organisms. DO consumed by these processes can be replenished by reaeration across the air-water interface. Basic physical factors, such as temperature, also affect concentrations of DO in streams. Oxygen solubility is inversely related to temperature. Concentrations of DO are of particular concern during the low-flow periods in summer months, when biological processes are most active and water temperatures are highest. As part of the effort to address the water-quality problem of low concentrations of DO, the PWD needs information about the potential for reaeration in Tacony/ Frankford Creek.

Reaeration coefficients are used in stream waterquality models to estimate concentrations of DO in reaches affected by excessive organic loadings. Stream velocity and dispersion characteristics are important physical properties that affect stream water quality, including DO. Reaeration is directly related to stream velocity, which controls mixing, as well as traveltime through and residence time in, pools and riffles. Dispersion, the scattering of particles in water, determines concentration attenuation as a solute is transported downstream.

Stream velocity, dispersion characteristics, and reaeration coefficients can be determined by time-of-travel studies that use dye- and gas-tracer techniques. Velocity and dispersion data collected from a dye injection can be used to make predictions regarding time of arrival, peak concentration, and duration of a constituent dissolved or suspended in the flow at any given point. Analysis of the loss of a tracer gas from injection site to downstream sites can be used to determine the oxygen reaeration coefficient of stream reaches under the study conditions.

In 2009, the U.S. Geological Survey (USGS), in cooperation with the PWD, conducted a study to determine time-oftravel, dispersion characteristics, and oxygen reaeration coefficients for selected reaches in Tacony/Frankford Creek. The data contained in this report on the results of the study will aid the city of Philadelphia, PWD, as well as State and local officials, planners, and managers in making decisions concerning water-quality management in the Tacony/Frankford Creek Basin. Water resources in the basin are used for many purposes, including recreation and wildlife habitat, as well as municipal and industrial purposes. Managing water resources for such a variety of uses makes an understanding of physical factors such as stream velocity and dispersion characteristics essential. However, this study was conducted at one known streamflow, and therefore, the extension of results from this study to other flow regimes should be made carefully.

\section{Purpose and Scope}

This report documents and presents the analysis of data collected for determination of stream velocity, dispersion characteristics, and oxygen reaeration coefficients for selected reaches of Tacony/Frankford Creek, Philadelphia, Pa., during summertime low-flow conditions. The dye- and gas-tracer studies documented in this report were conducted under baseflow conditions from August 18 through September 3, 2009, on three sub-reaches of the 2-mi study reach.

On the basis of data collected from three dye injections, traveltimes to leading edge, peak, centroid, and trailing edge are presented for downstream sub-reaches. On the basis of the results of the dye tracing and concurrent constant-rate gas injection, reaeration coefficients for the sub-reaches were determined. Values for the reaeration coefficients determined from the field tracer-gas method were compared to values calculated by two alternate methods that use equations relating stream physical characteristics or the timing of daily maximum concentrations of DO to reaeration coefficients.

\section{Description of Study Area}

Tacony/Frankford Creek is a minor tributary to the Delaware River and drains about $30.4 \mathrm{mi}^{2}$ of southern Montgomery and Philadelphia Counties in southeastern Pennsylvania (fig. 1). Originating in Montgomery County, Tookany Creek flows southward and enters Philadelphia County (and also the city of Philadelphia, because the city and county borders are coincident), where it is renamed Tacony Creek (fig. 1). At the confluence of the former Wingohocking Creek, Tacony Creek is renamed Frankford Creek. Sections of the stream above and below this confluence are included in the study area, and for this report, the stream will hereafter be referred to as Tacony/Frankford Creek unless specific reaches are otherwise identified.

In Philadelphia, the urban effect on this stream is dramatic, and most of its natural tributary drainage system has been diverted into pipes and combined sewers. The original stream valleys were leveled with millions of cubic yards of fill to provide sites for development. These buried streams now flow in some of the largest sewers in the city's 3,000-mi drainage system (Levine, 2004). The USGS mapped estimated fill in stream valleys in Philadelphia as part of an analysis of topographic change, for which existing topographic maps were digitized to allow digital comparison of topography during different time periods (Chirico and Epstein, 2000). Since 1931, fill in these valleys has resulted in several instances of subsidence, which resulted in substantial loss of property (Chirico and Epstein, 2000). In most cases, these underground streams were designed as combined sewers, carrying both raw sewage and stormwater runoff, which is typical of many older American cities.

During the late $19^{\text {th }}$ and early half of the $20^{\text {th }}$ centuries, major channel and drainage modifications were made within this basin and throughout the city. By the mid 1920s, Wingohocking Creek, once the major tributary to Tacony/Frankford Creek draining about $13 \mathrm{mi}^{2}$, had been enclosed completely underground. All its base flow has since been diverted to a municipal sewage-treatment plant. Other small tributaries have also been rerouted with combined storm water and sanitary sewers and associated overflow outfalls (CSOs). During rain 
or snowmelt events, runoff from impervious areas is directed to the CSOs. It is likely that these stream modifications and large amounts of impervious area associated with urbanization in the drainage basin have resulted in decreased infiltration and increased runoff and stormflows far exceeding those natural to this basin. By the 1940s, flooding on Frankford Creek became a regular occurrence, and a flooding-prevention program was initiated to determine what channel modifications would reduce flooding on Frankford Creek (Knappen Engineering Company, 1947). Frankford Creek has since been rerouted and channelized below the Wingohocking confluence down to the Delaware River. During storm events, numerous other CSOs discharge directly to the creek between Castor Avenue and the Delaware River. The location of CSOs with National Pollutant Discharge Elimination System (NPDES) stormwater permits as of 2007 in the study reach are shown in figure 1.

Other than the open space flanking Tacony/Frankford Creek and nearby institutional properties, most of the drainage area of the stream in the city of Philadelphia currently is paved or developed. From the border with Montgomery County to Castor Avenue, a narrow strip of land immediately adjacent to, and on both sides of, Tacony/Frankford Creek in Philadelphia (fig. 1) is city-owned open space called Tacony Creek Park and is part of the Fairmount Park system. Tacony Creek Park is generally unpaved and forested with foot trails. Below Wyoming Avenue in the lower part of the study area ending at Castor Avenue, the Juniata Golf Course (part of Tacony Creek Park) flanks the stream (figs. 1 and 2).

The mouth of the former Wingohocking Creek is commonly referred to as the Wingohocking outfall and has been designated as the T14 outfall by the PWD. This CSO outfall is on the west bank of the stream near the Juniata Golf Course in the Juniata neighborhood of the city (fig. 2). Stormflow enters the stream after rising above the level of a gate within the CSO. Below this former confluence, Tacony Creek is renamed Frankford Creek until the stream flows into the Delaware River about 2.8 mi downstream.

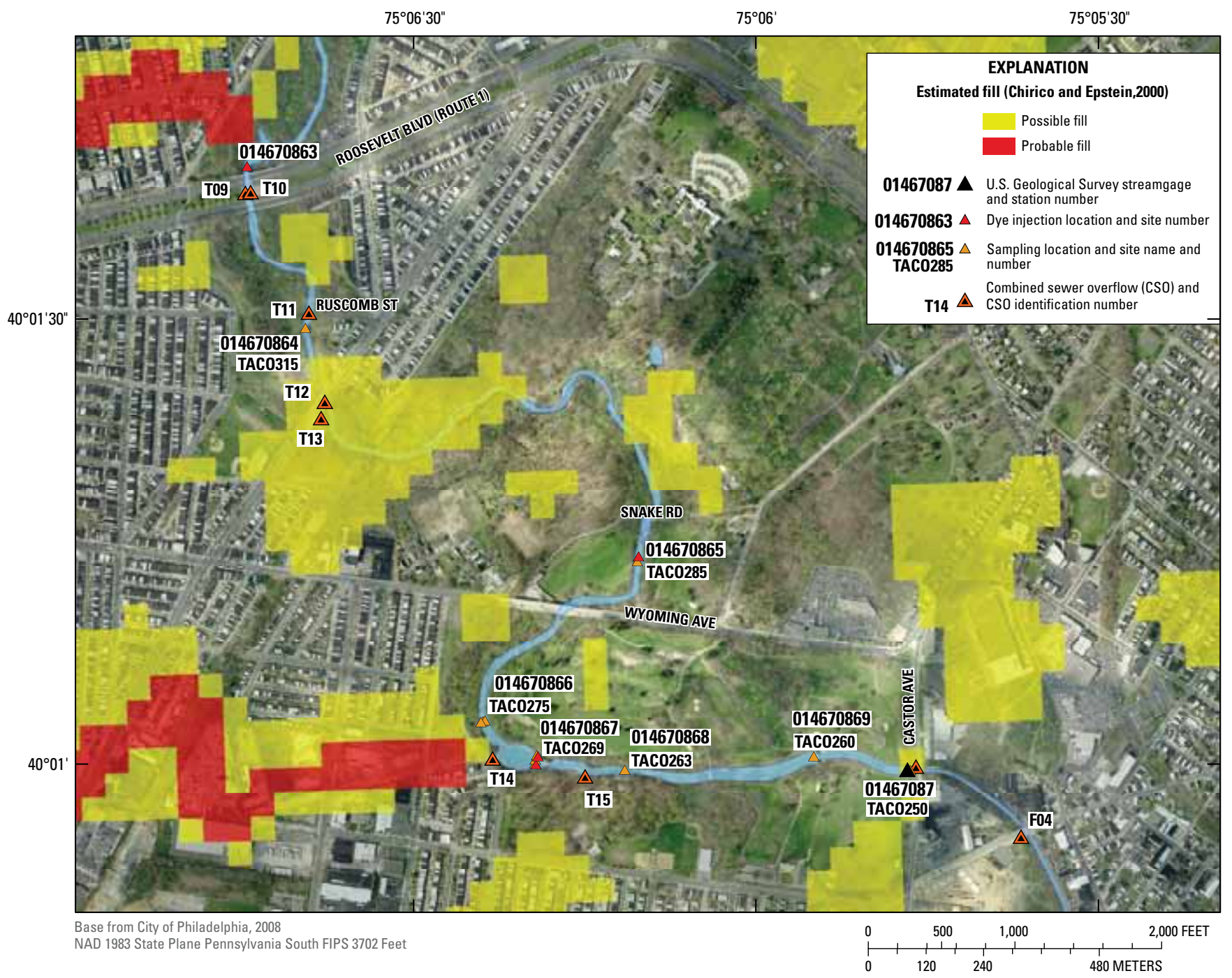

Figure 2. Study reach of Tacony/Frankford Creek and estimated location of nearby buried stream valleys in Philadelphia, Pa. 
The USGS operates two continuous streamgages currently measuring stage and water quality on Tacony/Frankford Creek, 01467086 Tacony Creek above Adams Avenue (Adams streamgage) and 01467087 Frankford Creek at Castor Avenue (Castor streamgage) in cooperation with the PWD (fig. 1). The Adams streamgage, located approximately at the city boundary, has a drainage area of $16.7 \mathrm{mi}^{2}$ and has been active since being restarted September 2005. An historical streamgage, Tacony Creek at County Line, located 1,000 ft upstream from the current Adams streamgage at the same datum, was active from 1965 to 1986. The elevation of the Adams streamgage datum is $61.11 \mathrm{ft}$ above NGVD 29. The Castor streamgage has a drainage area of about $30.4 \mathrm{mi}^{2}$ and has been active since establishment in 1982. The elevation of the Castor streamgage datum is $16.56 \mathrm{ft}$ above NGVD 29. Under base-flow conditions, little to no gain in streamflow typically is measured between the Adams and Castor streamgages because of diverted tributary base flow and low rates of groundwater discharge.

Tookany, Tacony, and Frankford Creeks are relatively low-gradient streams. From topographic maps, the mean slope is estimated to range from 0.001 to $0.007 \mathrm{ft} / \mathrm{ft}$ in the study area.

\section{Study Reach}

The study reach is a 2-mi section of Tacony/Frankford Creek, which extends from just above Roosevelt Boulevard (U.S. Route 1) to the USGS Castor streamgage (01467087) (fig. 2). The PWD has assigned identification numbers to sites on Tacony/Frankford Creek that will be used hereafter to identify the ends of sub-reaches, such as TACO250 for the Castor streamgage (fig. 2; table 1).

The channel of Tacony Creek is relatively natural in the upper part of the study section from Route 1 to above the T14 outfall (fig. 2). Below the confluence of the T14 outfall, Frankford Creek is an urban stream with channels altered by humans. In the lower part of the study section, which flows through the neighborhoods of Juniata and Frankford, the stream has been straightened and, about $680 \mathrm{ft}$ upstream from the Castor streamgage, is dammed and partly lined with concrete. At and downstream from the Castor streamgage, Frankford Creek is an artificially straightened and cleared trapezoidal channel with a concrete bed until the stream empties into the Delaware River. Design capacity of the cutoff channel is $10,000 \mathrm{ft}^{3} / \mathrm{s}$ (Knappen Engineering Company, 1947).

In the stream reaches studied, no streamflow is withdrawn or diverted. However, on the basis of a series of streamflow measurements, the stream appears to lose water in some reaches, perhaps to groundwater or to leaky gravity interceptors within the sewer system (Jason Cruz, Philadelphia Water Department, oral commun., 2009).

Relations between stream stage and flow in the study area are dominated by in-stream section controls, such as weirs and riffles. In the upper sub-reach of the study section from Route 1 to the Snake Road bridge upstream from Wyoming Avenue (fig. 2), the stream appears to flow through a relatively natural series of riffles and pools, with pool depths generally less than $2 \mathrm{ft}$ under base-flow conditions observed in August and September 2009. From the Snake Road bridge to the dam in the golf course (site TACO260, fig. 2), the presence of man-made structures such as the bridges, CSO outfalls, and the dam itself have resulted in scour holes and (or) backwater conditions, and thus greater stream depths, up to about $3 \mathrm{ft}$ or more in places. In backwater conditions, flow typically is restricted (or obstructed) such that stream velocities upstream from the restriction are reduced relative to free-flowing stream velocities, and the amount of water in storage in the reach upstream from the restriction increases as streamflow increases.

The stream follows a natural channel from the Snake Road bridge to the confluence with the T14 CSO outfall (fig. 2), where the stream surface area expands and stream depth increases because of the scouring at the outfall. Immediately downstream from the scour pool at the T14 CSO outfall (hereafter referred to as the T14 pool), a large gravel bar divides the stream into two channels and then multiple winding shallow channels (site TACO269 is at the head of the gravel bar, fig. 2). Large boulders and slabs of concrete are present at the head of the gravel bar. Towards the downstream end of the steep reach associated with the gravel bar, the stream converges to form a single channel near site TACO263 (fig. 2). Another CSO outfall (T15, fig. 2) discharges to this reach from the south side of the stream. About 1,500 ft downstream from the gravel bar is a concrete dam (site TACO260, fig. 2) that obstructs flow, causing backwater conditions and resulting in a large pool that extends about $1,000 \mathrm{ft}$ upstream from the dam. Although the dam is notched, the notch commonly is blocked with debris and trash in the stream, which exacerbates backwater conditions. During summer 2009 base-flow conditions, depths in the pool immediately behind the dam were about $3.5 \mathrm{ft}$ when the notch was blocked and less than $2 \mathrm{ft}$ when the notch was open (fig. 3). Just below the notch in the dam, a concrete slab covers the streambed to a v-notch weir, which causes turbulence and associated reaeration of the stream. Below the weir, the stream flows again through a series of riffles and pools down to the concrete control at the Castor streamgage (site TACO250, fig. 2).

\section{Geology and Physiography}

The city of Philadelphia straddles two physiographic provinces, the Atlantic Coastal Plain and the Piedmont (Sevon, 2000). The Coastal Plain is a flat-lying area consisting of unconsolidated sediments of Tertiary and Cretaceous age that were deposited on older metamorphic rocks of the Piedmont (fig. 1). The surficial contact that separates the Coastal Plain from the rolling topography of the Piedmont is the Fall Line. From the Fall Line, the Coastal Plain deposits dip gently to the southeast, and this orientation partly controls the general flow direction of creeks in the Philadelphia area.

The Piedmont is traversed by many deep narrow stream valleys. Near the Fall Line in Philadelphia, most of these 

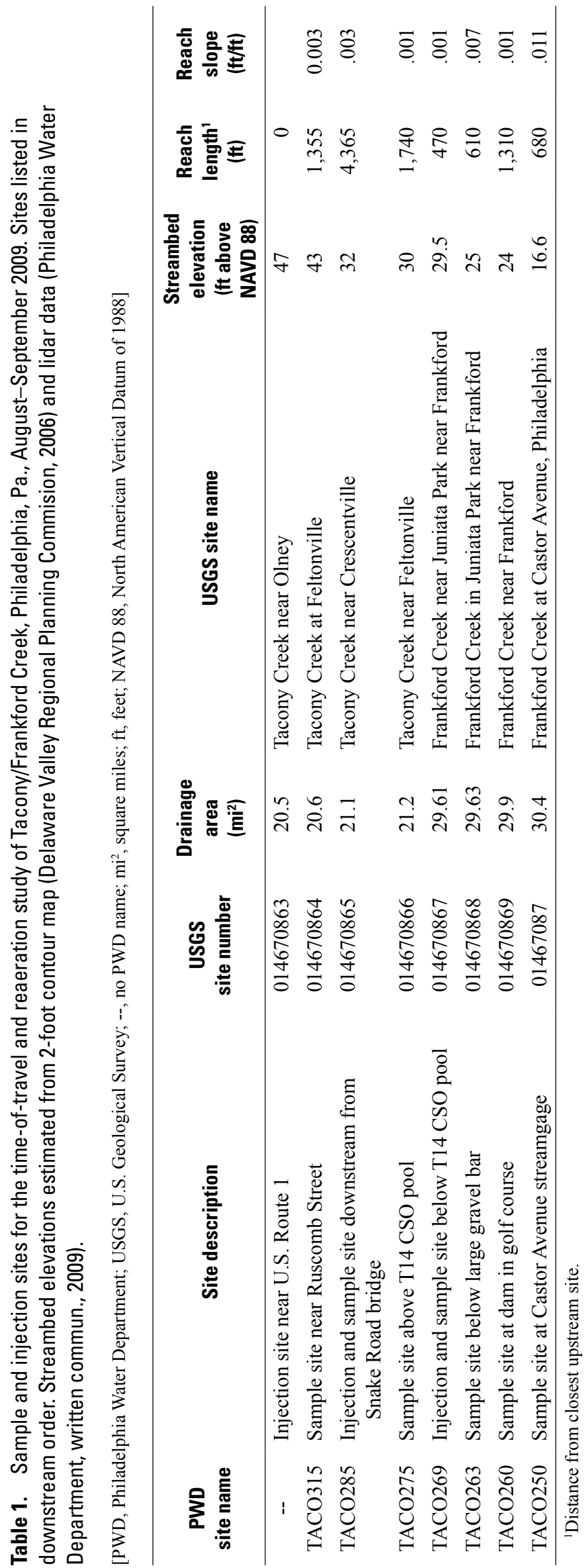

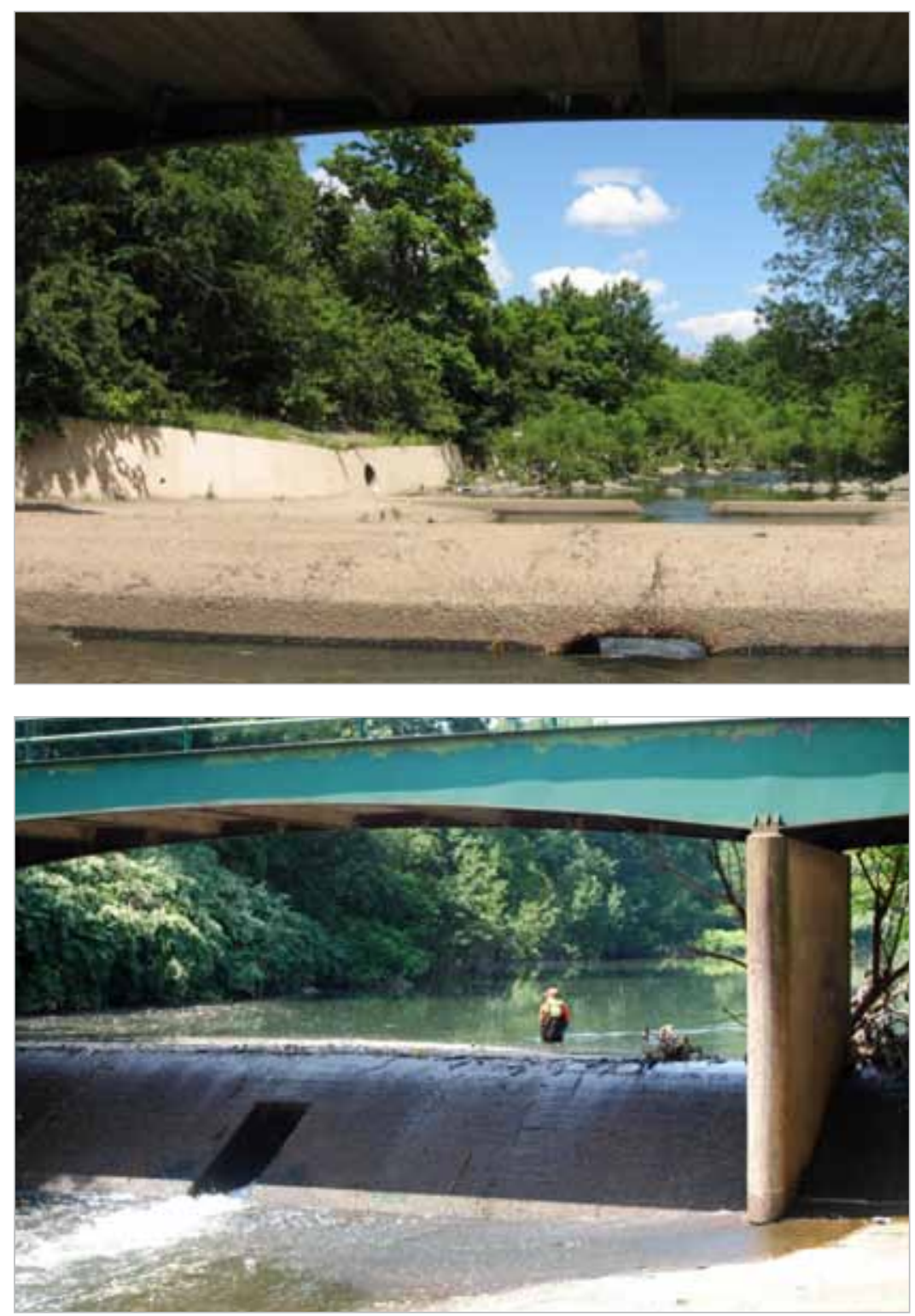

Figure 3. Backwater conditions in Frankford Creek at the dam in the Juniata Golf Course, Philadelphia, $\mathrm{Pa}$., $(A)$ when the dam notch was open on July 18 , 2009, and (B) when the dam notch was completely blocked on August 18, 2009. (Photograph 3B by Hannah Hamilton, U.S. Geological Survey, August 18, 2009. 
valleys have eroded through the Coastal Plain sediments and exposed the underlying rocks of the Wissahickon Formation, a metasedimentary rock of Paleozoic age in the Piedmont (Bobyshell, 2006; Bascom and others, 1909). On the basis of topographic maps of Philadelphia published in the 1890s (Bascom and others, 1909), these stream valleys, some of which were later filled in, averaged about $1,000 \mathrm{ft}$ in width and ranged from depths as much as $60 \mathrm{ft}$ in the Coastal Plain to more than $120 \mathrm{ft}$ in the Piedmont.

The study reach spans the Fall Line. In the upstream section of the study reach, the drainage area of Tacony/Frankford Creek is underlain solely by the Wissahickon Formation (fig. 1). In the middle-to-lower sections of the study reach, the creek has cut down through the Coastal Plain deposits exposing the bedrock in places.

\section{Methods of Data Collection and Analysis}

This study used a single slug injection of the tracer dye and a constant-rate-injection (CRI) of the tracer gas to determine time-of-travel and dispersion characteristics and reaeration coefficients. Time-of-travel and dispersion characteristics were calculated on the basis of documented procedures contained in USGS Techniques of Water Resources Investigations (TWRIs) (Hubbard and others, 1982; Kilpatrick and Cobb, 1985; Kilpatrick and Wilson, 1989) as well as Jobson (1996). In the CRI method, changes in concentrations of the tracer gas (propane) between sampling points are used to determine oxygen reaeration coefficients for the reach. Procedures for the reaeration component of the study are documented in Kilpatrick and others (1989). In general, unless noted, standard procedures described in these reports were followed during the study.

Because the city of Philadelphia was concerned with low concentrations of DO during typical low streamflow in the vicinity of the Castor streamgage during the warm summer months, the study was conducted during base-flow conditions with stable streamflows while water temperatures were warm. All field work was done from mid July through early September 2009.

\section{Stream Reach Selection}

Estimates of stream velocity, in addition to other information, are needed to select practical injection and sample locations that define the ends of sub-reaches. To simplify computation of dye traveltime and dispersion at selected locations downstream from the injection, the dye must be completely mixed vertically and laterally in the streamflow. The length of channel required for optimum mixing depends on stream velocity, width, depth, and slope. Using information collected from preliminary field surveys, or estimated on the basis of historical data, and topographic maps, the distance necessary to ensure mixing at the first downstream sampling section from proposed injection sites on Tacony/Frankford Creek was calculated by standard methods (Kilpatrick and Wilson, 1989)

A preliminary estimate of mean stream velocity was obtained by evaluating specific conductance data from the two USGS continuous-record streamgages (fig. 1), Adams streamgage (station 01467086) and Castor streamgage (station 01467087), that are equipped with water-quality monitors maintained by PWD. Specific conductance minima related to stormflow dilution during small stream rises in July 2009 were used to estimate traveltime and mean velocity for 3.46 stream miles between these two streamgages. Using this approach, the estimated traveltime was about 18 hours, and an estimated mean velocity of approximately $0.28 \mathrm{ft} / \mathrm{s}$ was used to plan initial sampling intervals and injection times.

Field reconnaissance was necessary to refine the estimated time-of-travel, to select actual sampling sites, and to plan logistics for this study. To estimate mean velocity for each individual smaller sub-reach, informal streamflow measurements were made at several locations in July 2009. Reconnaissance of the lower part of the reach included inspection of the T14 pool and individual hydraulic structures to estimate the effects of these features on time-of-travel and reaeration. An Acoustic Doppler Current Profiler (ADCP) was used to determine depths and velocities in the pool just downstream from the T14 CSO outfall where the channel widens and deepens substantially. The pool below the T14 CSO outfall is approximately an acre in size and is clearly visible in aerial photos (fig. 4). Data collected by the ADCP at the T14 pool show that channel depth and cross-sectional area increases dramatically as the stream enters the pool. Under base-flow conditions, stream depths are typically less than $2 \mathrm{ft}$ upstream from the pool, but depths are as great as $12 \mathrm{ft}$ in the pool. Velocity measurements within the pool were extremely low, less than $0.10 \mathrm{ft} / \mathrm{s}$.

To evaluate the extent of stratification of this large pool and its potential effect on traveltime through the pool, a sonde with four water-quality sensors (temperature, DO, specific conductance, and $\mathrm{pH}$ ) was towed behind a kayak and lowered in several locations throughout the pool. The largest differences in water quality with depth were for temperature, which ranged from 2 to $2.5^{\circ} \mathrm{C}$ between readings taken at the surface and near-bottom depths of the pool. Smaller changes in concentrations of DO $(1-2 \mathrm{mg} / \mathrm{L})$ and specific conductance $(600-680 \mu \mathrm{S} / \mathrm{cm})$ were also noted during this brief survey of field conditions. On the basis of this initial survey, stratification of the pool seemed likely, and dye loss due to storage within the pool during the study was expected to be minimal.

The stream constricts again at the outlet of the T14 pool but separates into two main channels at the head of a gravel bar (fig. 4). Because of the possibility that the tracer dye might not be well mixed exiting the pool, plans were made to collect dye and gas samples at three cross-section points representing flowlines $(25,50$, and 75 percent of flow) at sites just upstream from the T14 pool, just downstream from the T14 pool at the 


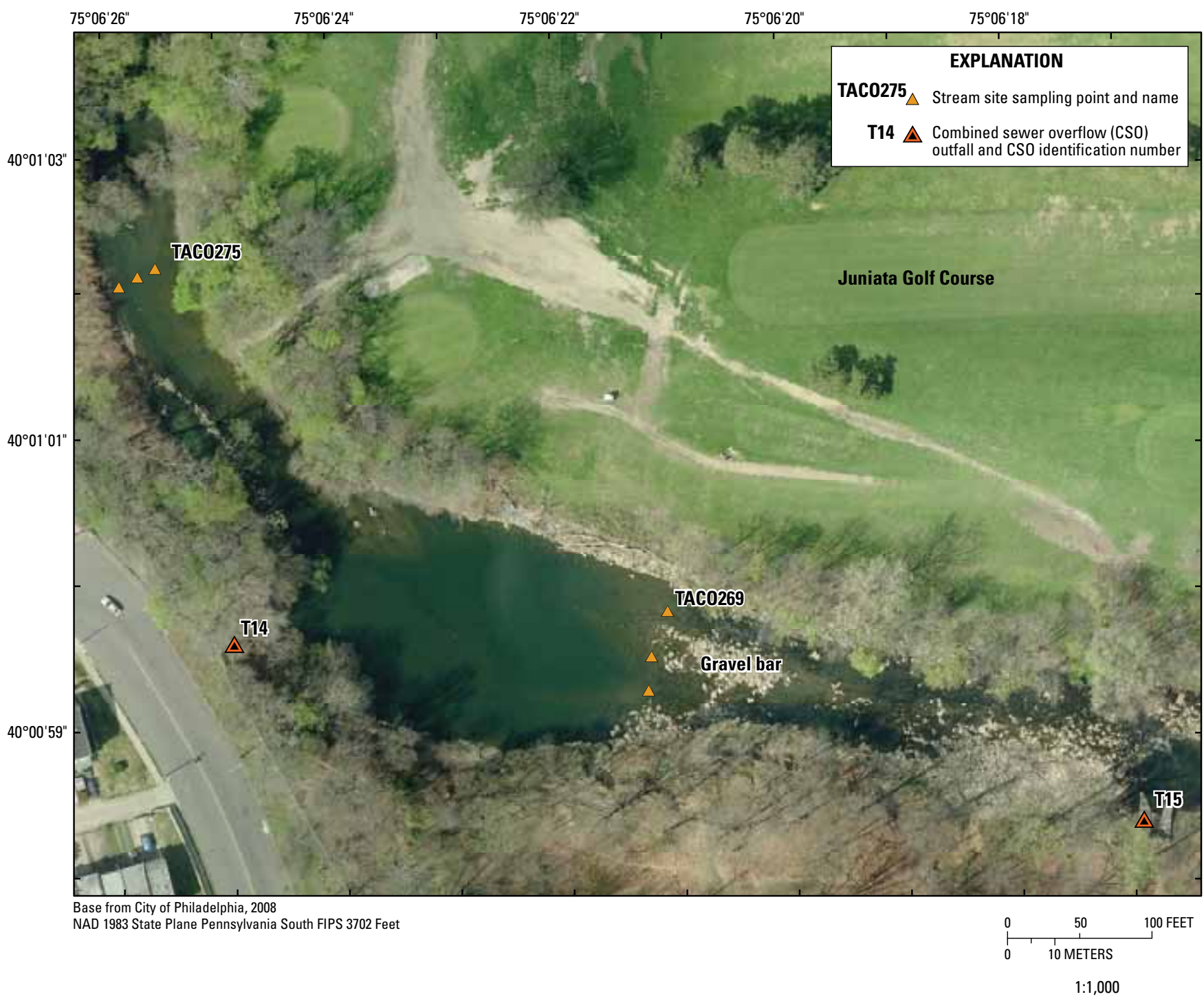

Figure 4. Configuration of gravel bar at outlet of pool below T14 combined sewer overflow outfall on Tacony/Frankford Creek, Philadelphia, Pa., 2008. 
head of the gravel bar, and immediately downstream from the gravel bar where flow converged to form a single channel.

Upon completion of the initial reconnaissance, it was determined that low stream velocities and logistics precluded the entire study from being conducted continuously and that the study reach would be divided into two sub-sections to shorten sampling duration. Safety was largely a concern because of hazardous conditions associated with night-time sampling and because access to the study reaches through the Juniata Golf Course was limited after dark, about 8 p.m. in August. A total of three sub-sections were eventually selected for the overall study, although initially only two (an upper and lower) sub-sections were planned. Sample and injection sites were assigned separate identification names and numbers by PWD and USGS (table 1; fig. 2) to be consistent with both the PWD and USGS databases. In downstream order, the sites were: the injection location at Route 1; sampling site at Ruscomb Street (TACO315); sampling and injection site just below Snake Road bridge (TACO285); sampling site just above the T14 pool (TACO275); sampling and injection site just below the T14 pool at the head of the gravel bar (TACO269); sampling site below gravel bar (TACO263); sampling site in pool just above dam at golf course (TACO260); and sampling site at Castor streamgage (TACO250). The actual sequence of sites sampled on each day is listed in table 2.

The lower sub-section study was conducted first on August 18, 2009, and initially was planned to extend from the injection site below the Snake Road bridge (TACO285) to the Castor streamgage (TACO 250). Because of thunderstorms during the evening on August 18, gas and dye sampling was terminated at about 8 p.m. before the dye cloud had passed completely through the two most downstream sampling sites (TACO260, TACO250) as indicated by dye concentrations collected up to that time. Field conditions, including long traveltimes in the pool behind the dam at the golf course, required that the original lower sub-section (above T14 pool to the Castor streamgage) be sub-divided into two shorter overlapping sections. Gas and dye sampling had to be repeated in the section of the lower reach below the T14 pool to the Castor streamgage.

A supplemental dye study was conducted on August 20, 2009, after the first run on August 18 to evaluate the effects of backwater at a dam on the Juniata Golf Course on traveltime and sampling schedules. These data collected on August 20 underwent only preliminary analysis and are not reported here, although samples were retained for further analysis if warranted. During August 18-20, a shopping cart and excessive

Table 2. Stream discharge measured at sites in study reaches, Tacony/Frankford Creek, Philadelphia, Pa., on August 18, September 1, and September 3, 2009.

[PWD, Philadelphia Water Department; USGS, U.S. Geological Survey; Q, stream discharge; $\mathrm{ft}^{3} / \mathrm{s}$, cubic feet per second; --, no data or not measured]

\begin{tabular}{|c|c|c|c|c|c|c|c|}
\hline Date & $\begin{array}{c}\text { PWD } \\
\text { site name }\end{array}$ & $\begin{array}{c}\text { USGS } \\
\text { site number }\end{array}$ & Site description & $\begin{array}{c}\text { Distance } \\
\text { from } \\
\text { injection } \\
\text { point } \\
\text { (feet) }\end{array}$ & $\begin{array}{c}\mathbf{Q}^{1} \\
\left(\mathbf{f t} \mathbf{t}^{3} / \mathbf{s}\right)\end{array}$ & $\begin{array}{c}\text { Reach gain } \\
\text { (loss) } \\
\left(\mathrm{ft}^{3} / \mathrm{s}\right)\end{array}$ & $\begin{array}{c}\text { Reach gain } \\
\text { (loss) } \\
\text { (percent) }\end{array}$ \\
\hline \multirow[t]{5}{*}{$8 / 18 / 2009$} & TACO285 & 014670865 & Injection/Snake Road bridge & 0 & 15.4 & -- & -- \\
\hline & TACO 275 & 014670866 & Above T14 CSO pool & 2,190 & 14.8 & -0.6 & -3.9 \\
\hline & TACO263 & 014670868 & Below gravel bar/large riffle & 3,270 & 12.1 & -3.1 & -20.4 \\
\hline & TACO 260 & 014670869 & At dam & 4,580 & 13.4 & 1.3 & 10.7 \\
\hline & TACO 250 & 01467087 & Castor streamgage & 5,260 & $\underline{13.0}$ & -.4 & -3.0 \\
\hline $9 / 1 / 2009$ & TACO269 & 014670867 & Injection/below T14 CSO pool & 0 & 15.7 & -- & -- \\
\hline \multirow[t]{5}{*}{$9 / 3 / 2009$} & -- & 014670863 & Injection/Route 1 & 0 & 14.2 & & \\
\hline & TACO315 & 014670864 & Ruscomb Street & 1,355 & 14.9 & .7 & 4.9 \\
\hline & TACO285 & 014670865 & Near Snake Road bridge & 5,270 & 15.2 & .3 & 2.0 \\
\hline & TACO275 & 014670866 & Above T14 CSO pool & 7,460 & 15.0 & -1.3 & -.2 \\
\hline & TACO250 & 01467087 & Castor streamgage & & $\underline{15.0}$ & & \\
\hline
\end{tabular}

${ }^{1}$ Discharge in italics estimated; underlined discharge from gage. 
trash were stuck in the notch at the siltation dam resulting in at least $1 \mathrm{ft}$ of backwater, thus substantially changing transport characteristics of the stream. It was concluded that periodic maintenance of the notch by golf-course personnel reduces backwater conditions, consequently decreasing traveltimes through the impoundment.

The remaining two sub-sections of the time-of-travel and reaeration study were conducted on September 1 and 3, 2009, after golf-course personnel partially cleared the obstruction in the notch in the dam (site TACO260). On September 1, for the study of the most-downstream sub-section, dye was injected just below the large T14 pool (TACO269), and samples were collected at TACO263, TACO260, and TACO250 (fig. 2). On September 3, for the study of the upstream-most sub-section, dye was injected just upstream from Route 1 (Roosevelt Boulevard), and samples were collected at sites TACO315, TACO285, and TACO275 (fig. 2).

\section{Discharge Measurements}

To characterize streamflow conditions and quantify dye recovery, discharge measurements were made at each sampling location. Measurement techniques conformed to standard USGS methods established by Rantz and others (1982). In addition, discharge measurements made prior to the arrival of the dye were used to partition stream cross sections into 25,50 , and 75 percent of flow for locating sample collection points at a stream site.

Discharge measurements were made at all stream sampling locations, except at the Castor streamgage (TACO250) on August 18, 2009, and the site just above the T14 CSO pool (TACO275) on September 3, 2009. Stage data at the Castor streamgage were used to determine discharge for the TACO250 site on August 18, 2009. Stream discharge at TACO275 was assumed to be about the same as the nearest upstream site TACO285 on September 3, 2009, as it was on August 18, 2009. Measurements of discharge made by USGS for the study (table 2) are stored in and available for retrieval from the USGS National Water Information System (NWIS) database.

\section{Water-Quality and Stage Measurements}

Multi-parameter water-quality sondes (model YSI 6920 V2 with optical sensor for DO) were placed in the stream at dye sampling sites on each study day to monitor selected characteristics and water depth. The sondes measured and recorded water temperature, $\mathrm{pH}$, specific conductance, concentration of DO, and stream depth continuously at 5-minute intervals, except at the Castor streamgage (TACO250), where an existing sonde installed for long-term measurements recorded data every 30 minutes. The sondes used at sampling sites were provided and calibrated by the PWD a few days before August 18, 2009, using USGS standard procedures (Wagner and others, 2006) and were not recalibrated over the study period.
The sonde at the Castor streamgage was calibrated by PWD on August 5, on the morning of August 18, and on August 25, 2009 (Stanton Popewiny, Philadelphia Water Department, written commun., August 2009). Whenever possible, the same sonde was used at a given site if that site was to be sampled on multiple days. Data from these sondes (listed in appendix 1) were used to evaluate stability of stream stage and variability of water temperature and chemical characteristics at sites during the study.

\section{Dye Injection, Sample Collection, and Analysis}

Standard field procedures (Kilpatrick and Wilson, 1989) and fluorometric procedures (Wilson and others, 1986) for conducting time-of-travel and dispersion studies using dye tracers were followed. The dye tracer used for this study was rhodamine WT, a nontoxic, fluorescent red chemical dye composed of 20 percent raw (active) dye material. Resulting dye concentrations in micrograms per liter or parts per billion were measured over a period of time to define the entire passage of the dye cloud. A total of four dye injections were made while conducting this study. Three of these (on August 18, September 1, and September 3, 2009) are presented in this report.

On August 18, August 20, September 1, and September 3, 2009 , a pre-determined quantity of 20-percent rhodamine WT was injected at the head of each sub-section by rapidly pouring the dye into the stream. Injections were made at midchannel, multipoint, or as a line injection across predominant flowlines (fig. 5, photo of injection). Locations of dye-injection sites and sampling points are shown in figure 2 .

To prevent contamination and interference from background levels of fluorescence, the downstream sub-section was injected first, to be followed by injection on the upstream subsection on a later day. However, as stated earlier in this report, the downstream section needed to be subdivided so that the injection on the most downstream subsection was on September 1 and injection on the most upstream subsection was on September 3, 2009. The mass of dye injected was determined by standard equations described by Hubbard and others (1982). Edges of the stream were not "tagged" with dye during injection to prevent dye from being held up in small eddies near streambanks. The amount of dye to be injected is calculated by considering factors of stream discharge, mean stream velocity, and the distance to and the minimum dye concentration expected at the farthest downstream sampling location. For this study, a target concentration of $10 \mu \mathrm{g} / \mathrm{L}$ at the downstream-most sampling location was used to estimate the amount of dye for injection. Given that dye amounts were so small, the actual mass injected was determined by weight using a specific gravity of 1.08 , a value supplied by the manufacturer (Abbey Color, oral commun., August 2009).

At each sampling site, prior to the arrival of the dye cloud, a sample was collected to determine background fluorescence of the water in the stream that was later subtracted from the sample fluorescence. Subsequently, a series 


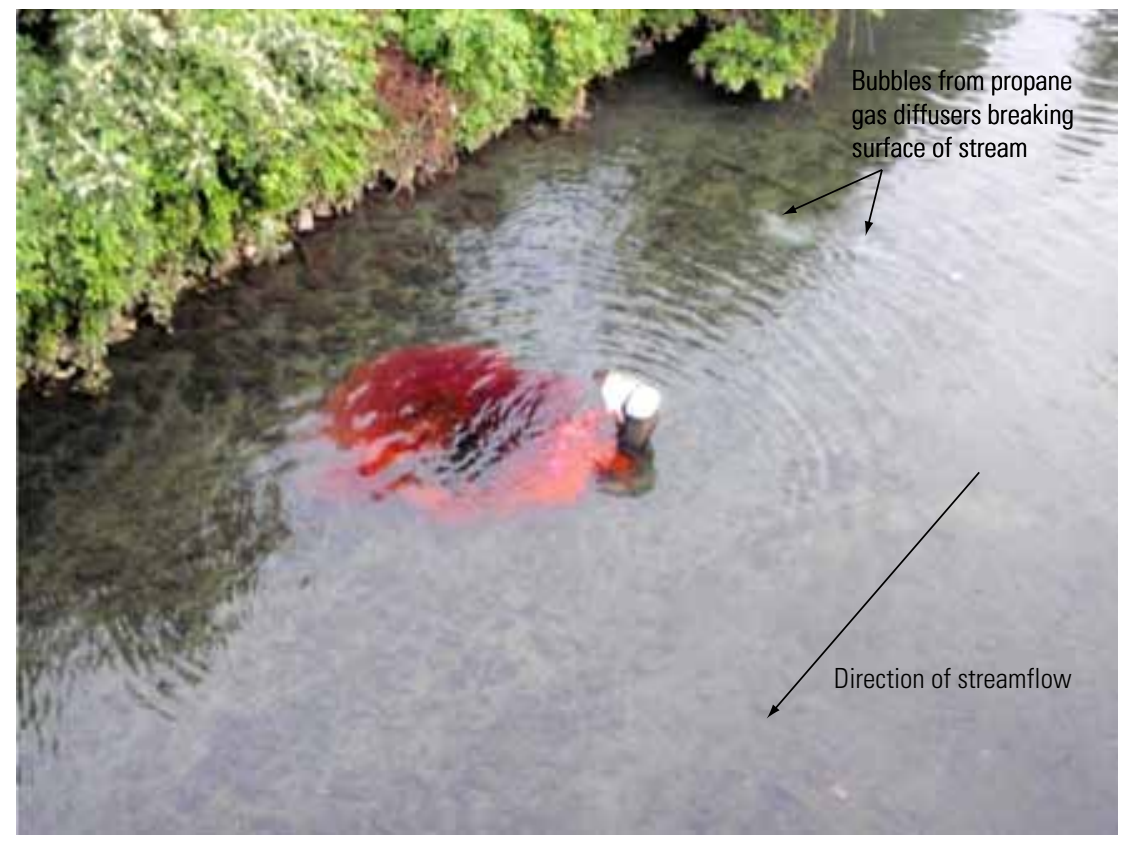

Figure 5. Dye injection and propane gas diffusion on September 3, 2009, in Tacony/Frankford Creek near U.S. Route 1, Philadelphia, $\mathrm{Pa}$.

(Photograph by Jason Cruz, Philadelphia Water Department, on September 3, 2009.) of samples was collected at each site to sufficiently define the passage of the dye cloud, typically to 2 percent of peak concentration.

Water samples were collected and analyzed for dye concentrations using standard methods (Kilpatrick and Wilson, 1989). Samples were collected by dipping a $100-\mathrm{mL}$ polyethylene bottle into the stream at approximately 0.6 depth at the sampling location. Samples were collected at up to three locations in each stream cross section. Typically, the first site downstream from an injection required collecting samples at locations representing the 25,50 , and 75 -percent flowlines (corresponding to measured 25, 50, and 75 percent of flow measured in the cross section) to verify complete mixing. On August 18, however, samples were collected at points representing the 25,50, and 75-percent flowlines at three sampling sites closest downstream from the dye injection to provide data on the extent of mixing, where unknown and possibly incomplete, through the complex sub-reach including the T14 CSO pool and divided channel of the gravel bar (fig. 4). At all other sampling sites, complete mixing was assumed, and only a single sample was collected at a point on the cross section representing the 50-percent flowline (50 percent of total flow).

Dye samples were analyzed in the field to define the progress of the dye cloud and to establish sampling frequency and duration. All samples were retained for subsequent analysis in the laboratory under controlled conditions. Samples for laboratory analysis were stored in closed containers to minimize possible photodegradation of the dye. Because fluorescence is strongly affected by temperature, samples were placed in a $70^{\circ} \mathrm{F}$ water bath in the laboratory and allowed to stabilize before measuring sample fluorescence with the fluorometer.

Results of laboratory analysis of the dye samples are listed in appendix 2.

In the field and laboratory, fluorometer readings were taken within several seconds of placing the sample in the cuvette holder once readings stabilized. Fluorometer readings were made using the most sensitive scale applicable to each sample. Typically, this required the lowest setting on the fluorometer, which read in the range from 0 to $10 \mu \mathrm{g} / \mathrm{L}$. The Turner Model 10-AU fluorometer was calibrated using standards of known concentration from the same dye lot as that injected. All samples were corrected for background levels of fluorescence on the basis of water samples collected before dye arrival.

\section{Dye Quality Control}

Quality control was assured during the study by checking fluorometer calibration in both the field and laboratory before and after field measurements using samples of known concentration from the same dye lot as that injected. Field blanks were collected at every sampling site each day. The fluorescence of distilled water, a laboratory blank, was also measured as a control. The dye standards were checked several times each day to assure calibration stability.

\section{Dye Data Smoothing}

For data analysis, dye concentrations were smoothed using a LOESS utility (Peltier, 2009) for Microsoft Excel. LOESS smoothing is a modern modeling method that builds on classical methods, such as linear and nonlinear least squares regression analysis. Modern regression techniques are designed to address situations in which the classical procedures do not perform well or cannot be effectively applied without excessive work. LOESS combines much of the simplicity of linear least squares regression with the flexibility of nonlinear regression. It does this by fitting simple linear models to localized subsets of the data to build up a function that describes variation in the data, point by point. 
The use of weights is based on the idea that points near each other in the explanatory variable space are more likely to be related to each other in a simple way (linear) than points that are further apart. Following this logic, points that are likely to follow the local model best influence model parameter estimates the most. Points that are less likely to actually conform to the local model have less influence on the estimates (Cleveland and Devlin, 1988).

\section{Propane Gas Injection, Sample Collection, and Analysis}

Standard field procedures (Kilpatrick and others, 1989) for conducting the reaeration component of the study using the constant-rate-injection method for one-dimensional-dispersion state were followed. The tracer gas used for this study was commercially available propane, obtained in 100-lb cylinders. The gas was injected at a nearly constant rate into the stream through two 2-ft long ceramic diffusers placed on the streambed at the dye-injection location. The rate of gas injection was monitored throughout each dye run (appendix 3).

On August 18, September 1, and September 3, 2009, propane gas was injected at the head of each sub-section by adjusting the gas flow until bubbles were just visibly breaking the surface of the stream, as can be seen about $25 \mathrm{ft}$ upstream from the dye injection on September 3 (fig. 5). Injections were made at two points located at approximately 25 and 75 percent of flow in the stream cross section, typically at, or a few feet upstream from, where dye was injected. Locations of dye and gas injection sites and downstream sampling sites for the three study subsections are shown in figure 2 .

Gas samples in triplicate were collected at 20-minute intervals over a period of about 2 hours using a modified DO sampler (fig. 6). The sampler was loaded with three empty glass 40 -mL vials (fig. 6) and plastic tubing was inserted into each vial before screwing on the sampler lid. The sampler was immersed to about 0.6 depth at sampling points at each stream site, and wooden plugs sealing the plastic tubing were removed, allowing stream water to fill the glass vials from the bottom several times. Plugs to the plastic tubes were replaced when all air in the sampler chamber had been displaced, and the sampler was moved to the edge of the stream for sample processing. For sample preservation, $2 \mathrm{~mL}$ of concentrated hydrochloric acid was injected using a syringe into each filled sample vial, and vials were capped underwater and chilled on ice. Samples were shipped overnight to a commercial laboratory (TestAmerica in Austin, Tex). When shipping samples, it was noted in information for the laboratory that a few samples (appendix 2) had small air bubbles in one or two of the three $40-\mathrm{mL}$ vials that comprised a sample so that they could avoid analysis of vials with bubbles. No sample was shipped with bubbles in all three vials. The laboratory reported that all samples were received in good condition except that sample $\mathrm{pH}$ was greater than 2 despite acidification in the field with hydrochloric acid.
Gas concentrations in the water samples were determined by the laboratory method RSKSOP-175 (Hudson, 2004). The minimum reporting level (MRL) for propane concentration was $0.5 \mu \mathrm{g} / \mathrm{L}$ for undiluted samples and was $1.5 \mu \mathrm{g} / \mathrm{L}$ for samples diluted 3-fold. About 30 percent of the environmental samples were not diluted and have the lower MRL of $0.5 \mu \mathrm{g} / \mathrm{L}$; the remainder had the higher MRL of $1.5 \mu \mathrm{g} / \mathrm{L}$.

\section{Gas Sample Quality Control}

Quality control was assured during the study by collection and analysis of field blanks, field replicates, trip blanks, and review of laboratory results. Field blanks of stream water were collected at one sampling site each day, typically in the morning before dye or gas had arrived at the stream site. One trip blank accompanied the environmental samples collected on September 3, 2009. Propane was not detected in any field blank or trip blank. Review of laboratory data included evaluation of gas recovery rates in matrix spike samples and comparison to other gases included in the analysis.

Field replicates were collected by immersing a second gas sampler adjacent to the primary sampler within 1 minute of primary sample collection. Field replicates were collected at one sampling site each day during the 2-hour period of watersample collection for gas analysis. Differences in concentrations between replicate environmental samples ranged from 6 to 8 percent. These differences between concentrations in replicate environmental samples were similar to those reported for matrix spike sample duplicates prepared in the laboratory. Differences in concentrations between five pairs of matrix spike duplicates ranged from about 2 to 10 percent with a median of 5 percent. In contrast, differences in concentrations between six pairs of laboratory check duplicates were lower, ranging from 0 to 5 percent, and were about 2 percent for most (four of six) pairs.

In addition to propane, concentrations of methane, ethane, and ethene gases were reported by the laboratory (appendix 2), although not requested as part of the analyses. Concentrations of methane were consistently above the reporting level and were used to assess relative recovery of the tracer gas propane. The methane gas is produced within the stream and was measured in background samples. Lower reported concentrations of methane generally correspond to lower reported propane concentrations at a given site (fig. 7), suggesting some loss of both gases in sampling and (or) laboratory procedures. The relations between reported concentrations of methane and propane gas at each site also suggest that the highest reported propane concentrations at each site are probably the most accurate. 


\section{$A$}

Lid screws onto lower section of sampler and has tubing to vent displaced air
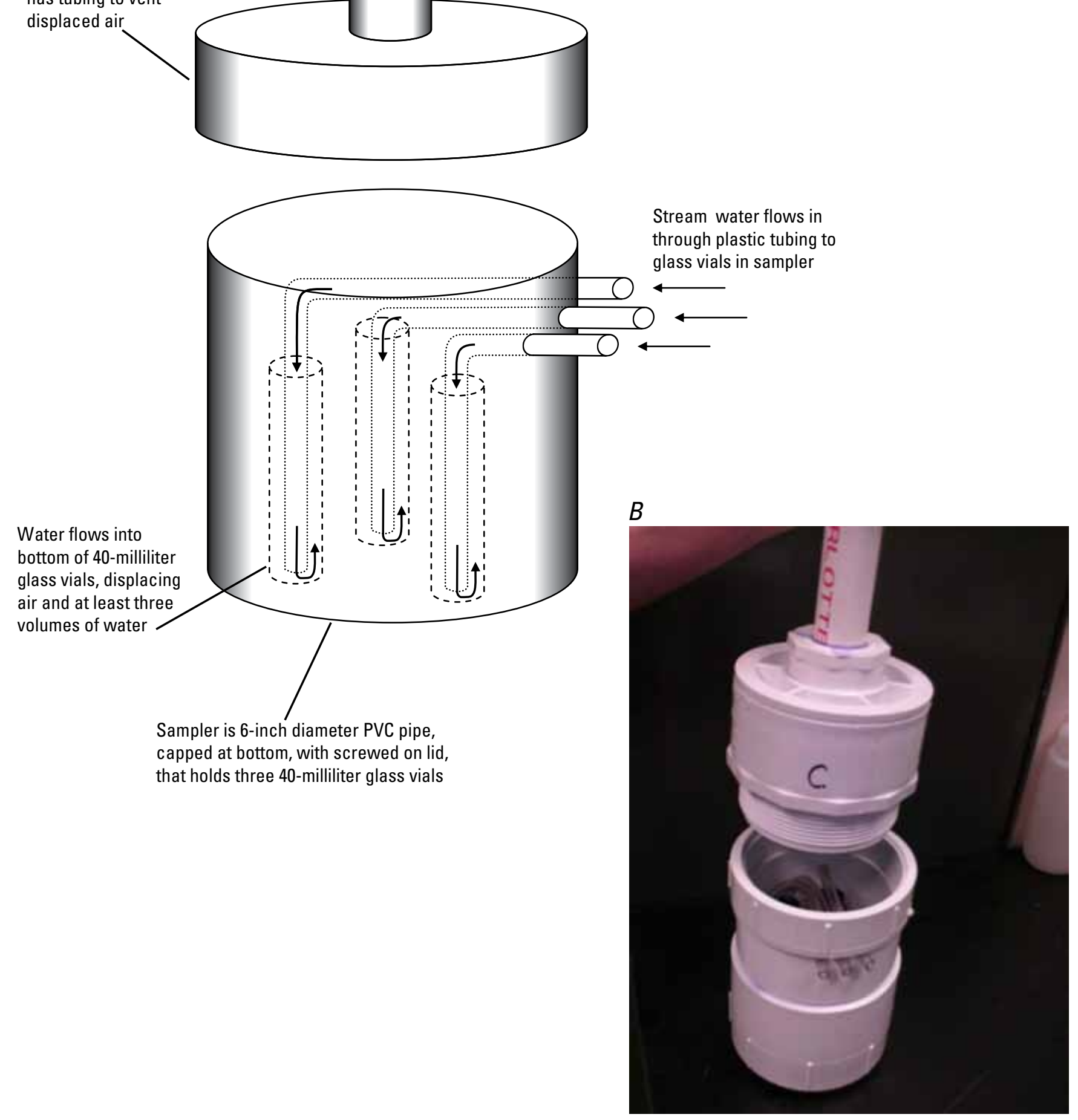

Figure 6. Diagram $(A)$ and photograph $(B)$ of the gas sampler used to collect stream samples for gas analysis in the reaeration study on Tacony/Frankford Creek, Philadelphia, Pa., 2009. (Photograph by Andrew Reif, U.S. Geological Survey) 


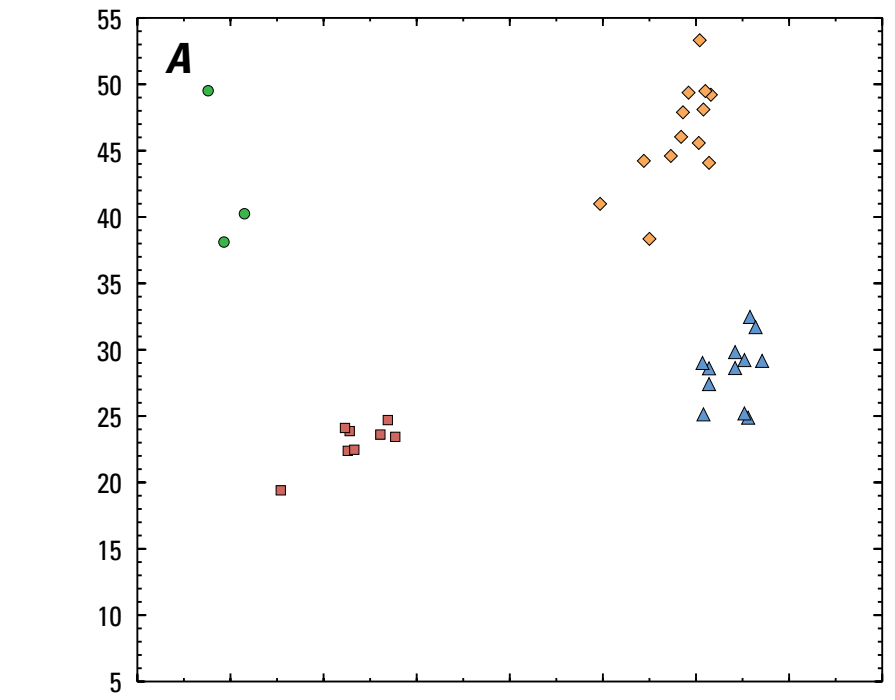

\author{
EXPLANATION \\ Sample sites with designations \\ showing location of sample \\ collection in stream channel, where \\ $\mathrm{R}=$ right, $\mathrm{M}=$ middle, and $\mathrm{L}=$ left \\ $\triangle \operatorname{TACO275}(\mathrm{R}, \mathrm{M}, \mathrm{L})$ \\ $\diamond \operatorname{TAC0269(R,M,L)}$ \\ - $\operatorname{TAC0263(R,M,L)}$ \\ - $\operatorname{TAC0260(M)}$ \\ $\operatorname{TACO263(R,M,L)}$ \\ $\triangle$ TACO250 (M) \\ $\diamond \operatorname{TAC0315(R,M,L)}$ \\ - $\operatorname{TAC0285}(\mathrm{R}, \mathrm{M}, \mathrm{L})$ \\ $\triangle$ TAC0275 (M)
}
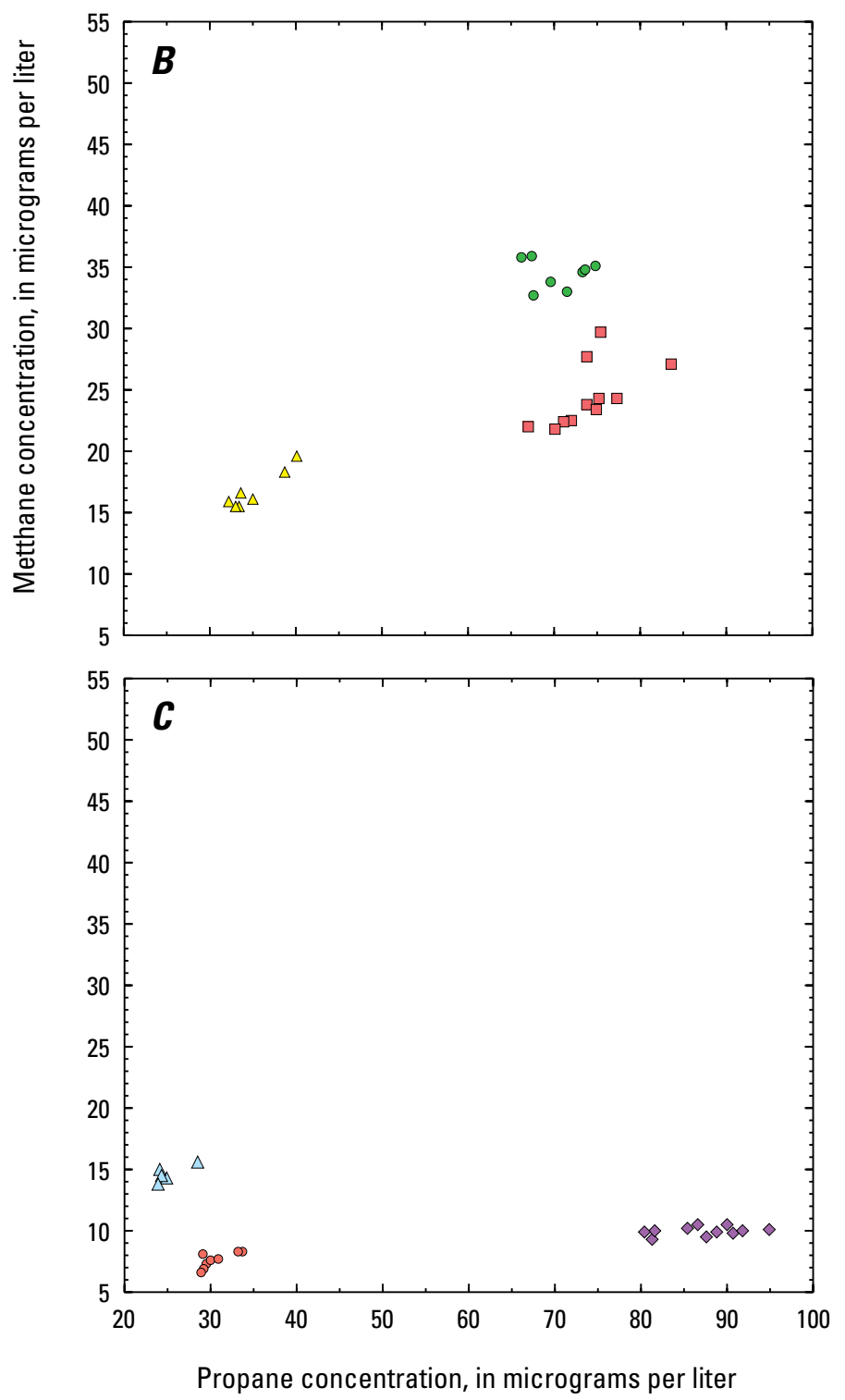

Figure 7. Methane concentrations in relation to propane concentrations in stream samples at each site sampled on (A) August 18, 2009; (B) September 1, 2009; and (C) September 3, 2009. 


\section{Determination of Time-of-Travel Characteristics and Reaeration Coefficients}

Measurements of time-of-travel of a dye tracer are used to define the movement of a solute in a river. The movement (response curve) of the dye tracer slug is used to help determine the reaeration coefficients. The movement of the dye also can be used to determine mean stream velocity and dispersion of a solute. For this study, the time-of-travel characteristics and reaeration coefficients were determined for one set of stream conditions.

\section{Study Conditions}

Ideally, the conditions of constant stream discharge (steady flow) and constant weather (wind speed and direction, air temperature, barometric pressure) need to be met to most simply determine reaeration rates. Equations used to calculate traveltimes for dye and gas (Kilpatrick and others, 1989) for this study assume constant stream discharge and do not include adjustments for any weather conditions except temperature. Weather conditions affect the rate of gas exchange from the creek and thus can affect reaeration rates. For example, rates of propane degassing or reaeration change in relation to the amount of wind shear on the surface of the water. Variable weather conditions during the course of the study may introduce complicating factors in determination of reaeration coefficients.

\section{Weather Conditions}

The study was conducted over three seasonably warm, dry, and relatively calm days in August and September 2009. Hourly air temperature, wind speed, wind direction, and barometric pressure data available for the nearby National Oceanic and Atmospheric Administration (NOAA) weather station at the Philadelphia International Airport (fig. 1) were used to assess weather conditions for the study area. During the study periods on each day, these data show that mean air temperatures ranged from 20.8 to $26.4^{\circ} \mathrm{C}$ and were 4 to $6^{\circ} \mathrm{C}$ higher on August 18 than on September 1 and 3, 2009 (table 3).

Median wind speeds were similar and ranged from about 8 to $10 \mathrm{mi} / \mathrm{h}$ on all study days, but wind directions differed over the study period (fig. 8). On August 18, 2009, the wind direction was predominantly from the southwest, whereas on September 1 and 3, 2009, the wind direction was predominantly from the east (fig. 8). The most downstream reach of the study area is oriented nearly east-west and the surface of the creek was observed to be blown slightly upstream when the wind was coming from the east on September 1, 2009. This lower reach is the widest and the least sheltered by
Table 3. Minimum, maximum, and mean hourly air temperature, wind speed, wind direction, and barometric pressure recorded at the Philadelphia International Airport during study periods on August 18, September 1, and September 3, 2009. Data from National Oceanographic and Atmospheric Administration (NOAA).

[degrees $\mathrm{C}$, degrees Celsius; mi/h, miles per hour; inches $\mathrm{Hg}$, inches of mercury]

\begin{tabular}{lcccc}
\hline & $\begin{array}{c}\text { Air } \\
\text { temperature } \\
\text { (degrees C) }\end{array}$ & $\begin{array}{c}\text { Wind } \\
\text { speed } \\
\text { (mi/h) }\end{array}$ & $\begin{array}{c}\text { Wind } \\
\text { direction' } \\
\text { (degrees) }\end{array}$ & $\begin{array}{c}\text { Barometric } \\
\text { pressure } \\
\text { (inches Hg) }\end{array}$ \\
\hline Minimum & August 18, 2009, from 05:54 to 20:13 & \\
Maximum & 22.0 & 0.0 & 0 & 29.95 \\
Mean & 32.8 & 33.0 & 280 & 30.08 \\
Median & 26.4 & 13.0 & 222 & 30.02 \\
& 25.0 & 10.0 & 220 & 30.01 \\
Minimum & 14.4 & 6.0 & 30 & 30.20 \\
Maximum & 24.4 & 11.0 & 360 & 30.26 \\
Mean & 20.8 & 8.1 & 107 & 30.23 \\
Median & 21.7 & 8.0 & 70 & 30.23 \\
& September 3, 2009, from 05:54 to 19:54 & \\
Minimum & 16.7 & 6.0 & 20 & 30.02 \\
Maximum & 26.7 & 11.0 & 360 & 30.16 \\
Mean & 22.6 & 8.3 & 110 & 30.08 \\
Median & 23.3 & 8.0 & 75 & 30.08 \\
\hline
\end{tabular}

${ }^{1}$ Wind direction of 0 or 360 degrees is due north, 90 degrees is due east, 180 degrees is due south, and 270 degrees is due west.

topography and vegetation compared to the upper reaches in the study area and, therefore, potentially most affected by the wind direction and speed.

Barometric pressure ranged from 29.95 to 30.26 in. over the study periods on August 18, September 1, and September 3, 2009, slightly higher than the estimated average of about 29.92 in. for Philadelphia and well within the historical record minimum and maximum barometric pressures reported in August in Philadelphia of 29.40 and 30.46 in., respectively (National Oceanic and Atmospheric Administration, 2010). On each study day from 6 a.m. to 8 p.m., the range in barometric pressure was $0.14 \mathrm{in}$. or less and, thus, was relatively constant for the day.

On August 18, 2009, a thunderstorm occurred at about 8 p.m. This storm was accompanied by a decrease in air temperature and an increase in barometric pressure (fig. 8). The barometric pressure declined from 30.08 in. at about 6 a.m. to a low of $29.95 \mathrm{in}$. at about 6 p.m. before rising slightly to 30.01 in. at 8 p.m. All dye and gas samples were collected from 6 to 8 p.m. prior to the onset of the storm. 

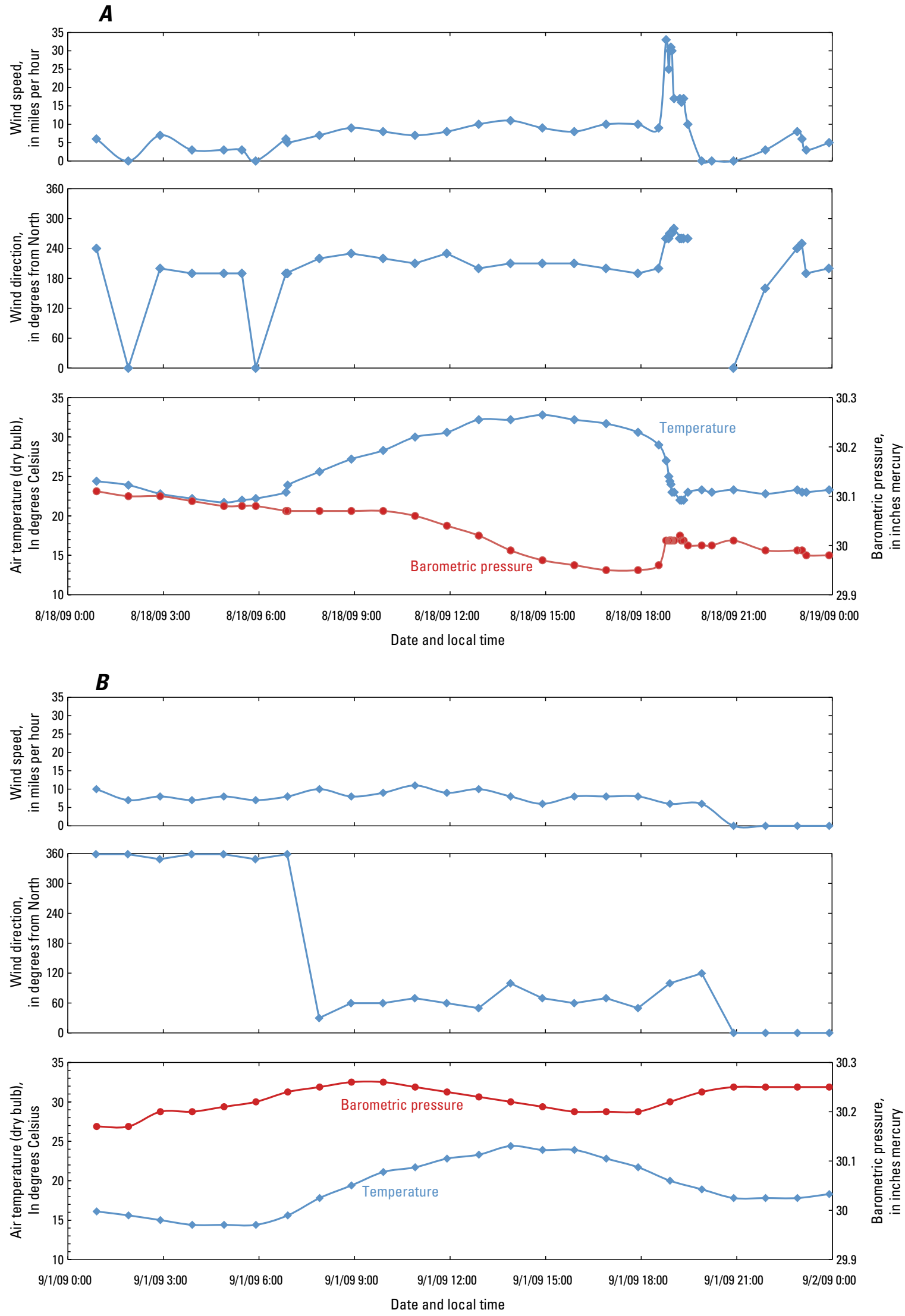

Figure 8. Wind speed, wind direction, air temperature, and barometric pressure recorded at the Philadelphia International Airport during study periods on (A) August 18, (B) September 1, and (C) September 3, 2009. Detailed description of wind direction given in table 3. 

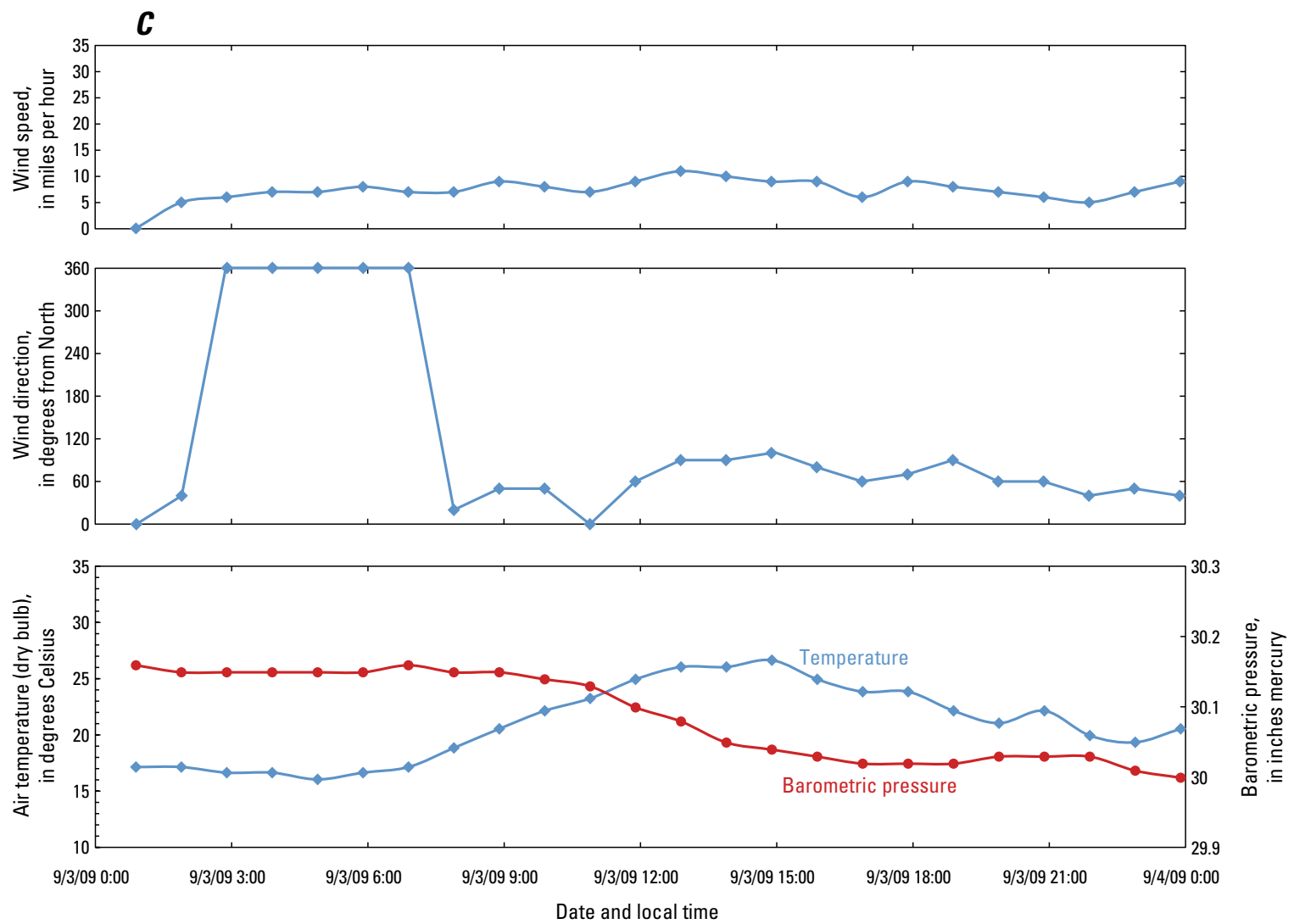

Figure 8. Wind speed, wind direction, air temperature, and barometric pressure recorded at the Philadelphia International Airport during study periods on (A) August 18, (B) September 1, and (C) September 3, 2009.-Continued Detailed description of wind direction given in table 3. 


\section{Streamflow and Stream Channel Conditions}

Knowledge of streamflow velocity is essential for prediction of solute transport. For example, at lower discharges in a stream, the corresponding slower velocities result in longer transport times. Of the two streamgages currently collecting continuous-streamflow information within the basin (fig. 1), the Castor streamgage is considered the index station given its proximity to all sampling locations. The maximum peak on record is 13,900 ft $3 / \mathrm{s}$ for Frankford Creek at Castor Avenue (drainage area of $30.4 \mathrm{mi}^{2}$ ), which equates to a unit discharge of $457 \mathrm{ft}^{3} / \mathrm{s} / \mathrm{mi}^{2}$ and is indicative of the urban signature of this stream. Data from this streamgage were used to determine stream discharge, evaluate stability of discharge each day over the study period, and compare discharge on study days to long-term statistical flows.

Streamflow was relatively steady and at, or approaching, base flow during the periods of sampling on August 18, September 1, and September 3, 2009, as can be seen on the hydrograph showing discharge at the Castor streamgage (fig. 9). Storms between the successive sampling runs resulted in stream rises between the August and September studies (fig. 9), and streamflow was still very slightly in recession on September 1, 2009. Measured discharge under base-flow conditions at the Castor streamgage was about $13 \mathrm{ft}^{3} / \mathrm{s}$ on August 18 and $16 \mathrm{ft}^{3} / \mathrm{s}$ on September 1 and 3, 2009.

Channel geometry changed over the period of study in summer 2009. The gravel bar and stream channel downstream of the bar apparently were rearranged noticeably between August 18 and September 1, 2009, by stormflows on August 21-23 and August 29-30, 2009 (fig. 9). In addition, the notch in the dam at site TACO260 was variably blocked by debris, resulting in different extents of the pool caused by backwater conditions upstream from the dam (fig. 3). On
August 18, 2009, the notch was nearly completely blocked by a shopping cart, trash, and other debris, and the pool depth just upstream from the dam was about $3.5 \mathrm{ft}$. On September 1 and September 3, 2009, the notch was only partially blocked, and the pool depth at the dam was about $2.5 \mathrm{ft}$.

Discharge generally was measured at each sampling and injection site (fig. 2) in the morning of each study day to locate sampling points within the cross section at each stream site and to allow subsequent calculation of dye recoveries. On the basis of this series of discharge measurements, little change in streamflow is apparent between stream sites on each study day except for one reach on August 18, 2009 (table 2). All discharge measurements were rated fair, indicating the measurement was within plus or minus 8 percent of actual flow (Sauer and Meyer, 1992). Differences in discharge of less than 16 percent between sites could be considered within the accuracy of the measurement technique, although differences of greater than 10 percent are probably real. From the site just below the T14 CSO scour hole (TACO269) to the site below the gravel bar (TACO263) on August 18, 2009, about a 20-percent reduction in flow was measured, indicating the stream lost water over the reach. The stream loss may be attributed to leaky gravity interceptors that follow the stream valley and (or) to the gravel bar in the steep sub-reach downstream from the T14 pool. Measurements on September 1, 2009 (table 3), do not indicate stream loss over this sub-reach, suggesting stream conditions differed from those on August 18, perhaps because of the changes in the configurations of the channel and gravel bar during the large storms on August 21-23 and 29-30, 2009. Base flow of 13 and $16 \mathrm{ft}^{3} / \mathrm{s}$ in Frankford Creek at Castor Avenue was about 30 and 74 percent higher than the long-term mean base flow of $10.2 \mathrm{ft}^{3} / \mathrm{s}$ for August and $9.2 \mathrm{ft}^{3} / \mathrm{s}$ for September, respectively. Long-term (1982-2008) means for these months were determined by hydrograph separation

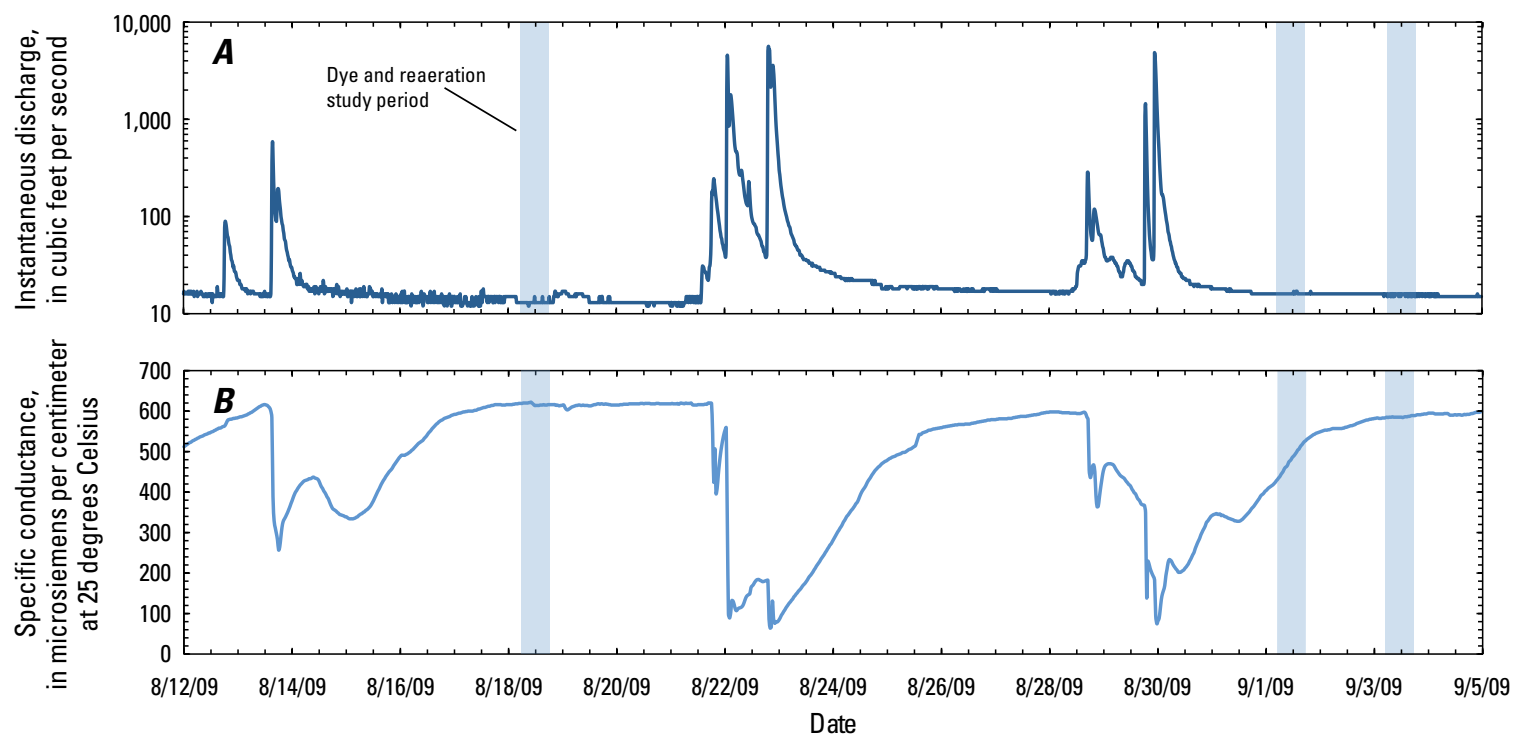

Figure 9. Stream discharge $(A)$ and specific conductance $(B)$ at streamgage 01467087 , Frankford Creek at Castor Avenue, Philadelphia, Pa., August 10 through September 10, 2009. 
of daily values, using HYSEP (Sloto and Crouse, 1996), a base-flow-separation program developed by the USGS. The long-term (1982-2008) annual mean base flow for the Castor streamgage is about $15 \mathrm{ft}^{3} / \mathrm{s}$.

\section{Stream Water Quality}

Data collected from water-quality sondes placed in the stream at each sampling site show that stream temperatures and DO concentrations rose each day from minima in the morning to maxima in the mid to late afternoon (fig. 10), patterns typical of diurnal cycles for these characteristics affected by solar radiation and stream algal activities. Stream $\mathrm{pH}$ also rose from daily minimum in the morning to maximum in the afternoon. Stream discharge and characteristics measured by the sonde, including specific conductance and turbidity, were more stable and indicative of hydraulic conditions. A listing of summary statistics for water-quality characteristics recorded by the sondes are given in appendix 1. Values of specific conductance were generally stable throughout each study day, except on September 1, 2009, when specific conductance gradually increased at all sites because the stream was still slightly in recession from a storm on August 29-30, 2009 (fig. 9).

\section{Time-of-Travel}

Traveltimes of the leading edge, peak concentration, and the trailing edge and other aspects of the dye transport were determined from time-concentration curves. These curves show dye concentrations for each sampling site plotted as a function of time since dye injection for each stream reach studied (figs. 11-13). All traveltime analyses used the Loesssmoothed curves rather than actual data.

Accurate time-of-travel measurements require that the dye cloud is well mixed in the stream before it is sampled. The area under the time-concentration curve is an indicator of stream mixing. Although higher concentrations may be present on one side of the creek, mixing is assumed complete if the areas under the curves are approximately equal. The area under each time-concentration curve was calculated by numerically integrating the Loess-smoothed dye concentrations of the stream samples. The entire area of the curve was integrated through the low concentrations of the trailing edge of the dye cloud, which commonly were measured at less than 2 percent of the peak concentration. At sites TACO260 and TACO 250 on August 18, 2009, the dye-cloud concentrations had just peaked at the time field activities, including sample collection, ended (about 8 p.m.) and the tails for these two curves are extrapolated (fig. 11) to estimate mass recovery. Although small differences in areas of the time-concentration curves are apparent, none of the areas calculated for the three flow-line samples $(25,50,75$ percent of flow) at each stream site differed more than 7 percent from the average area and, therefore, the dye is considered well mixed (table 4). Differences in areas greater than 10 percent of the cross-sectional average time-concentration area would indicate otherwise (White and Kratzer, 1993).

Traveltime to peak concentration $\left(T_{p}\right)$ was determined for peaks of the smoothed dye curves. The traveltimes of the leading edge $\left(T_{L}\right)$ and trailing edge $\left(T_{t 10}\right.$ and $\left.T_{t}\right)$ of the dye cloud from the injection site, where $\mathrm{T}_{\mathrm{t} 10}$ and $\mathrm{T}_{\mathrm{t}}$, are defined as 10 percent and less than or equal to 2 percent of the peak concentration, respectively, were determined by linear interpolation between sample points on the time-concentration curves (figs. 11-13). Traveltime to the centroid ( $\mathrm{T}_{\mathrm{c}}$ ) (or center of mass) of the dye cloud from the injection site also was calculated using the theory of incremental moments by numerically integrating with respect to time and area as outlined by Kilpatrick and others (1989). For the purposes of determining reaeration coefficients, traveltime from injection to the centroid $\left(T_{c}\right)$ of the dye cloud was calculated at each sampling site through the trailing edge $\left(\mathrm{T}_{t}\right)$, defined as less than or equal to 2 percent of the peak concentration. Traveltimes, including traveltime to the centroid $\left(\mathrm{T}_{\mathrm{c}}\right)$, and dye durations determined using the time to trailing edge $\left(\mathrm{T}_{110}\right)$, defined as 10 percent of the peak concentration, are provided in this report to be consistent with other routine time-of-travel studies (Kilpatrick and Wilson, 1989). Summaries of time-of-travel characteristics, including duration of the dye cloud, for each dye study are listed in table 5 and shown in figure 14. Dye-cloud durations were calculated on the basis of the elapsed time between the leading edge $\left(t_{L}\right)$ and trailing edge $\left(t_{t 10}\right)$ of the dye cloud. The maximum determined duration of the dye cloud was about 8.5 hours in the reach that spanned the T14 pool on August 18, 2009 (table 5), although durations at incompletely sampled downstream sites TACO260 and TACO250 were probably greater than 8.5 hours on that day.

The traveltime to the leading edge of the dye cloud can be used to estimate the minimum traveltime between two cross sections. The time required for a tracer cloud to arrive at a specific sampling point is an important factor in determining the concentration that can be expected. Traveltime to the centroid of the dye cloud can be used to estimate mean stream velocity and is required to compute stream reaeration coefficients. Mean traveltime between sampling locations is determined by the difference in centroid time and dividing by stream length.

\section{Unit Concentration and Dispersion Characteristics}

The concept of unit concentration, as described by Hubbard and others (1982) is a method to adjust for factors affecting the time-concentration curves such as 1) the amount of dye injected; 2) losses undergone by the dye; and 3) the discharge that serves to dilute the dye. Unit concentration is the concentration produced in one unit flow rate by the injection of one unit weight of solute, provided that no solute loss occurs. Jobson (1996) later refined this method by developing an equation used to convert any tracer-response curve to a unitresponse (UR) curve. This is a normalized curve that can then 

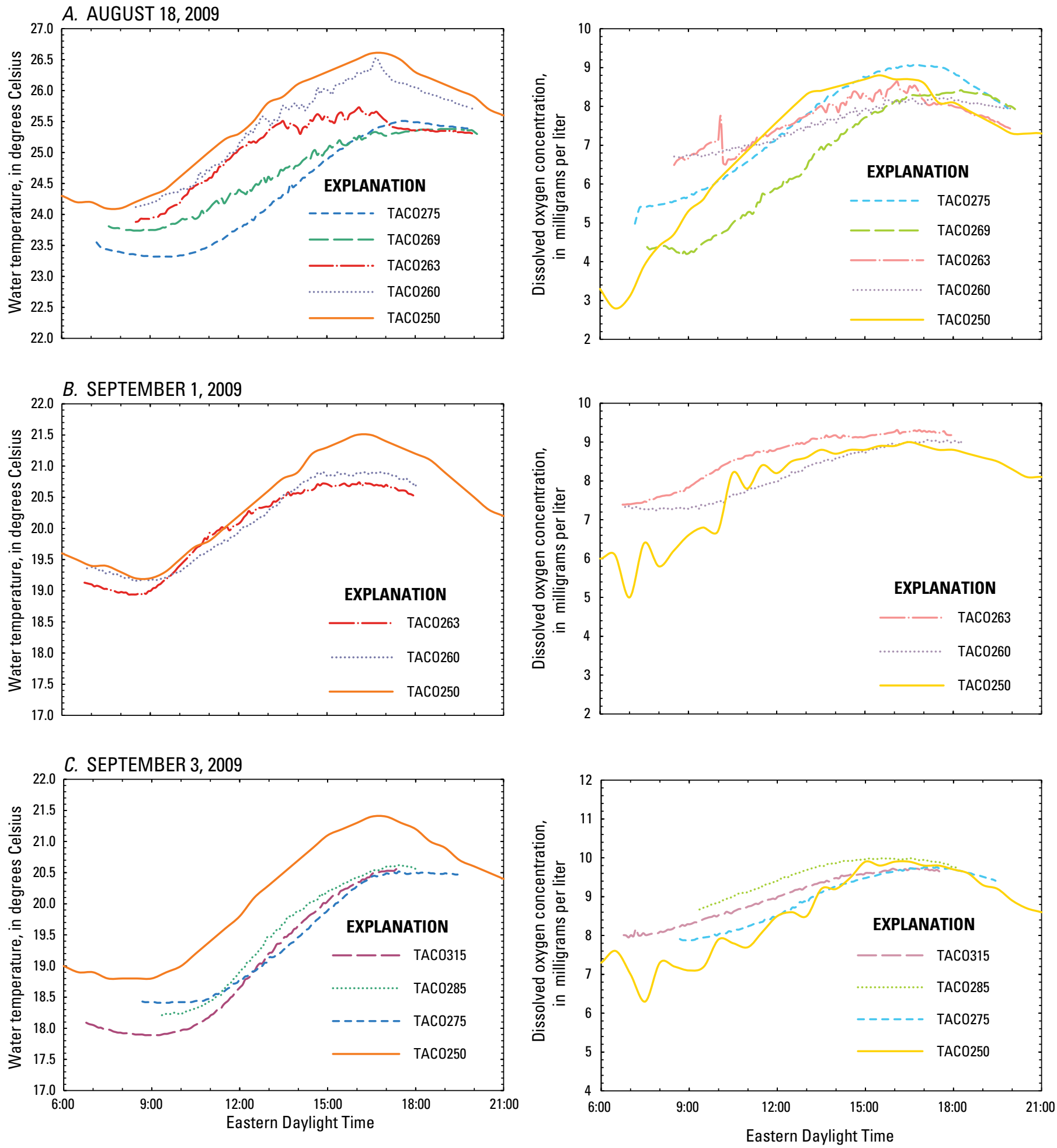

Figure 10. Stream temperatures and concentrations of dissolved oxygen measured by water-quality sondes at sampling sites in Tacony/Frankford Creek, Philadelphia, Pa., on (A) August 18, 2009; (B) September 1, 2009; and (C) September 3, 2009. 


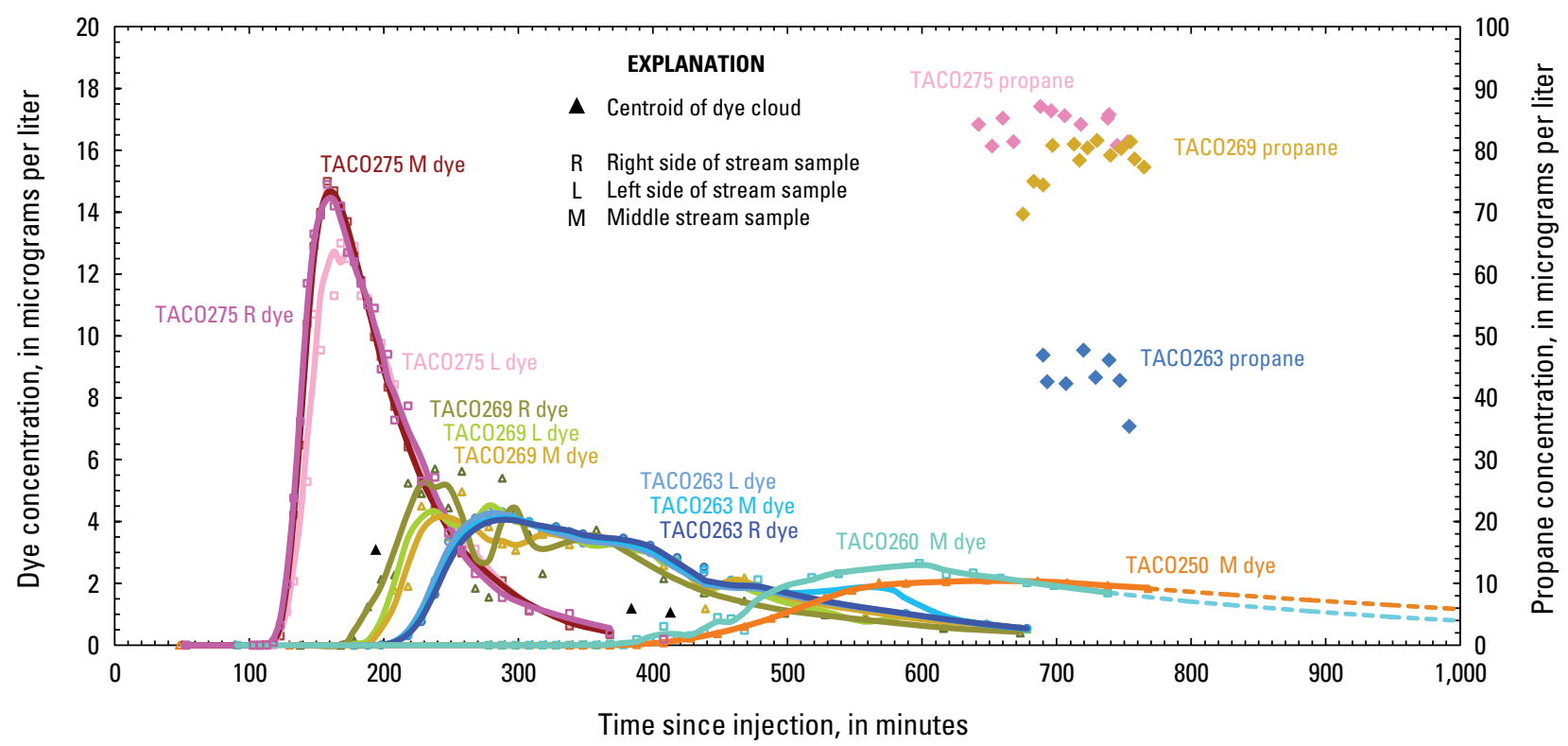

Figure 11. Dye and propane concentrations in relation to time since dye injection at five stream sites on Tacony/Frankford Creek, Philadelphia, Pa., August 18, 2009.

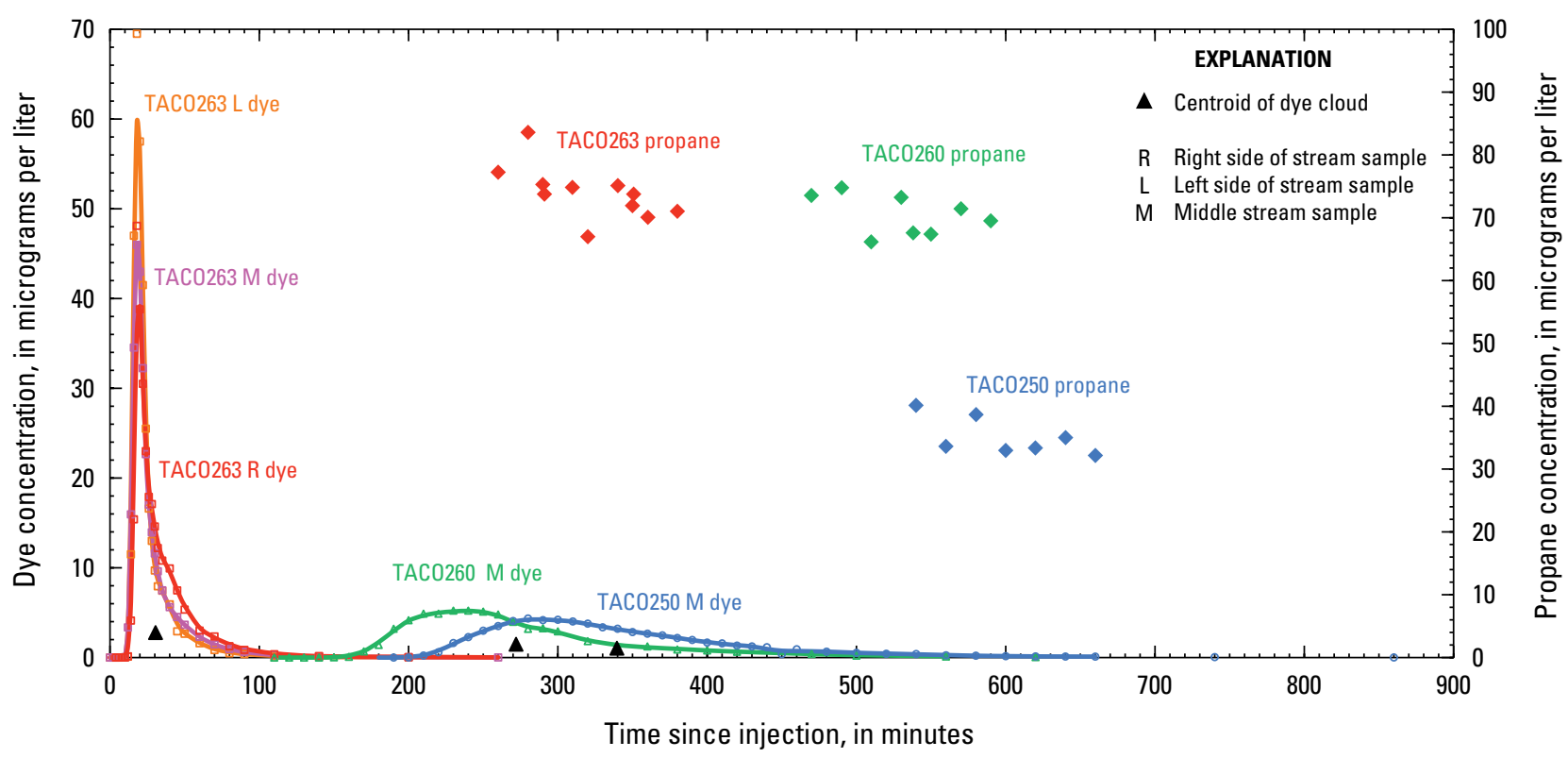

Figure 12. Dye and propane gas concentrations in relation to time since dye injection at three stream sites on Tacony/ Frankford Creek, Philadelphia, Pa., September 1, 2009. 


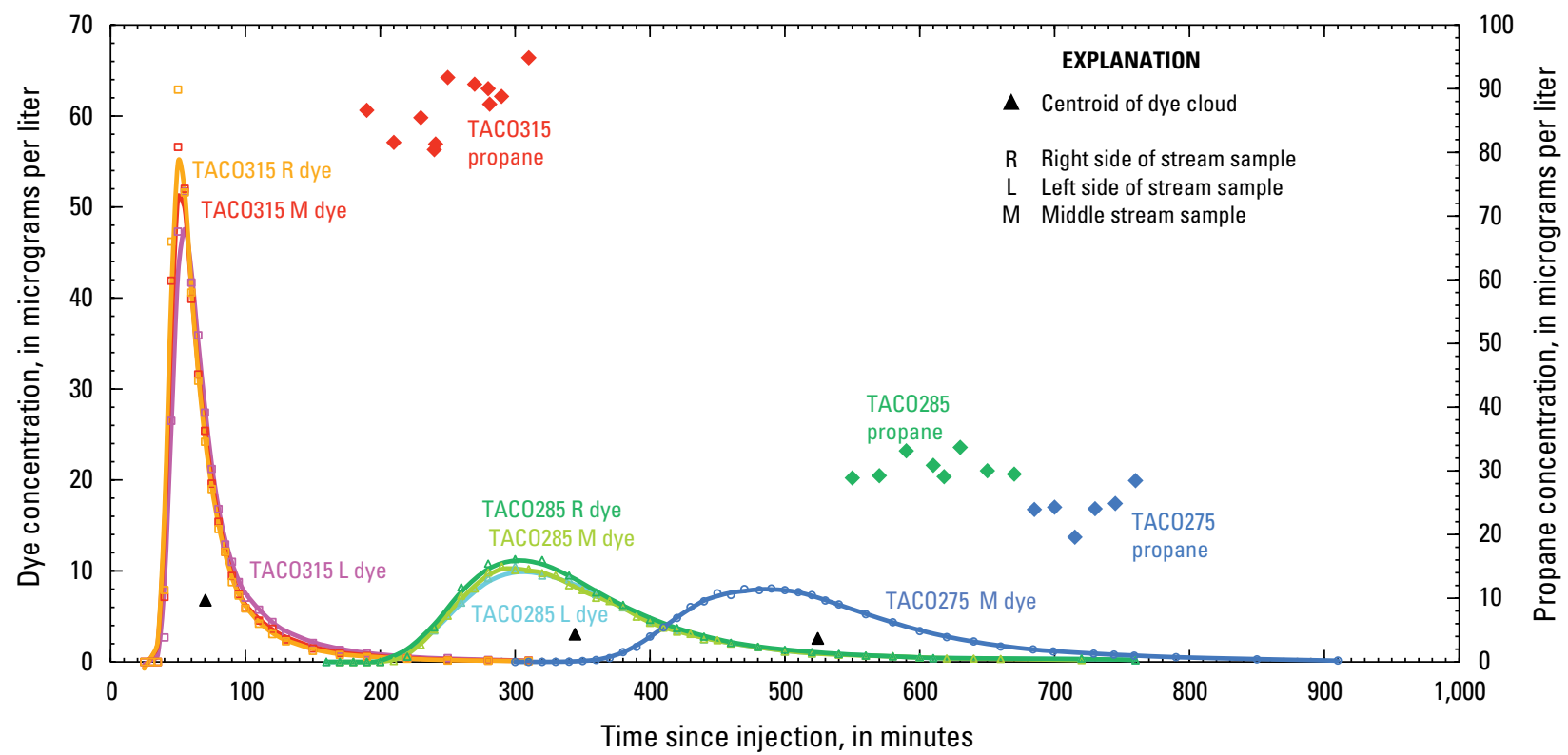

Figure 13. Dye and propane gas concentrations in relation to time since dye injection at three stream sites on Tacony/ Frankford Creek, Philadelphia, Pa., September 3, 2009. 
A. Lower reach from above T14 pool to below T14 pool on August 18, 2009

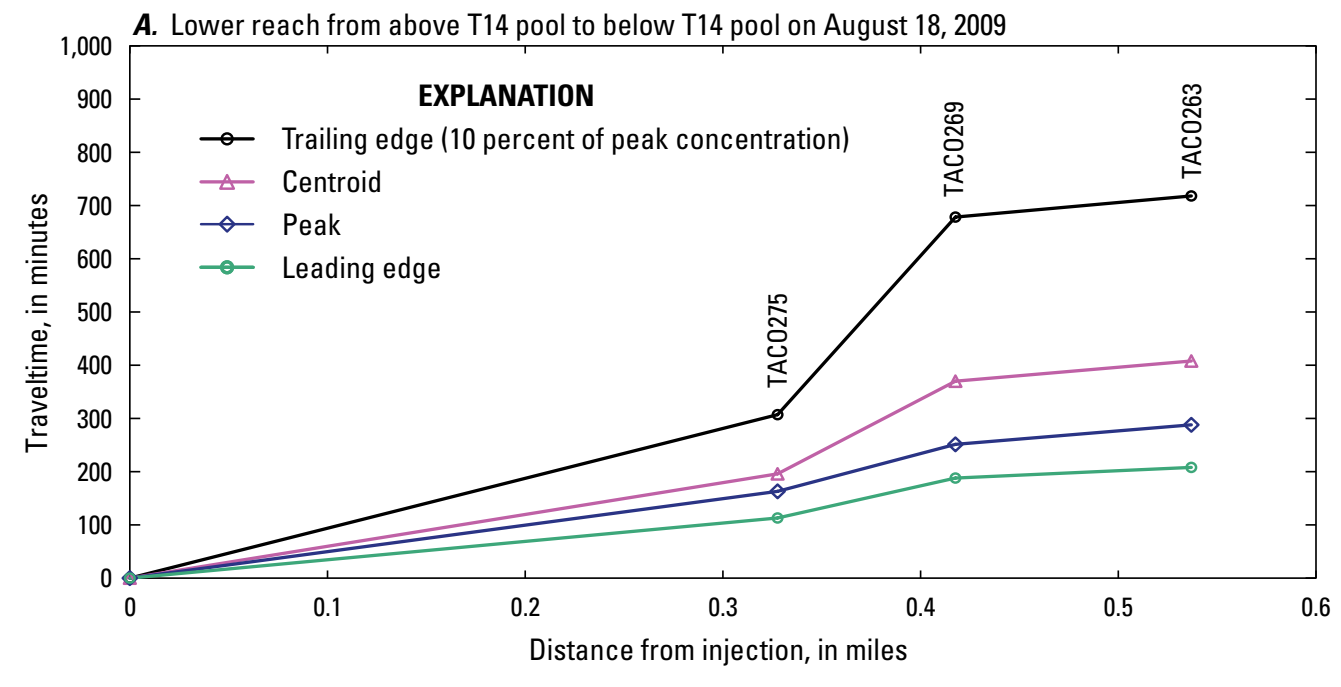

B. Lower reach from below T14 pool to steamgage at Castor Avenue on September 1, 2009

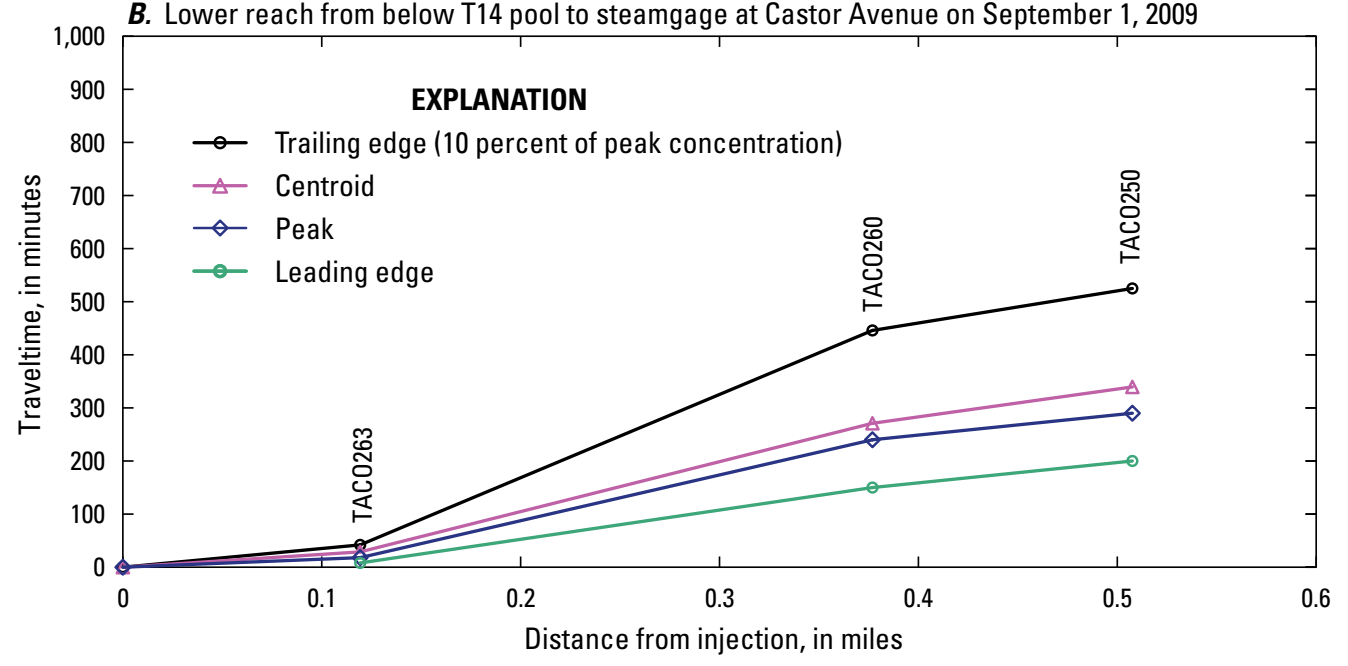

C. Upper reach from Route 1 to T14 pool on September 3, 2009

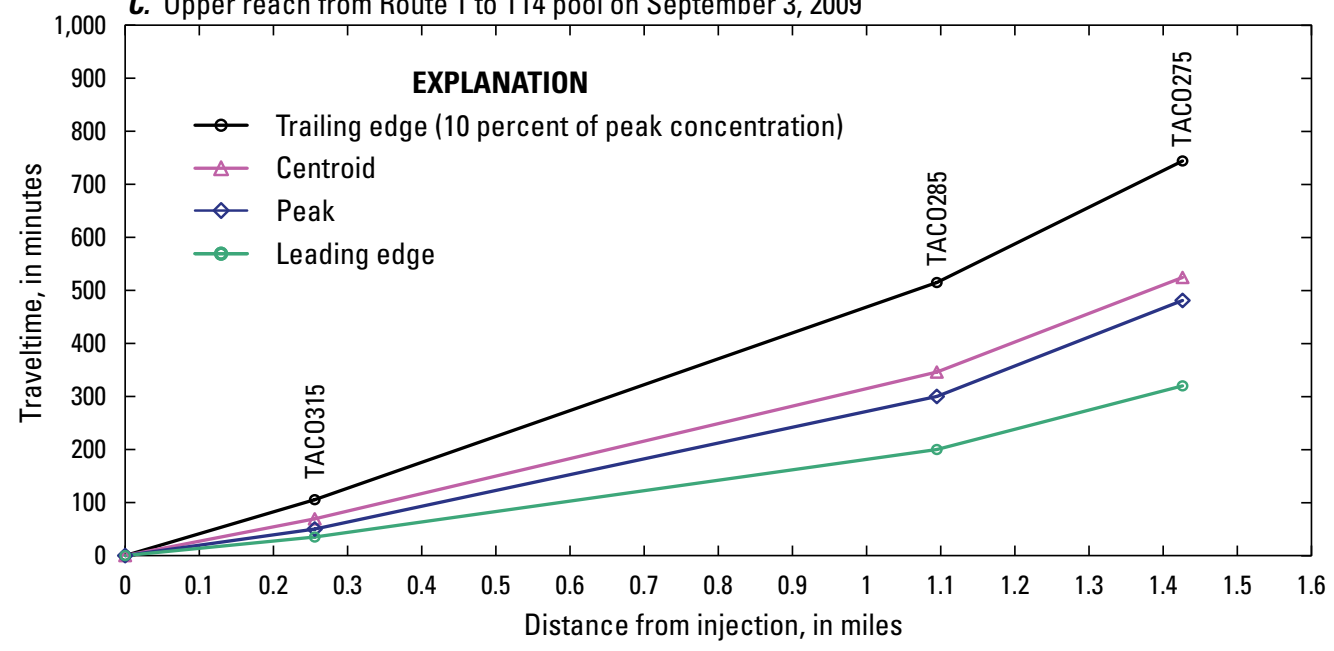

Figure 14. Traveltime of dye cloud in relation to distance from injection in Tacony/Frankford Creek, Philadelphia, Pa., for (A) lower sub-reach from above T14 pool to below T14 pool on August 18, 2009; (B) lower sub-reach from below T14 pool to streamgage at Castor Avenue on September 1, 2009; and (C) upper reach from Route 1 to T14 pool on September 3, 2009. 


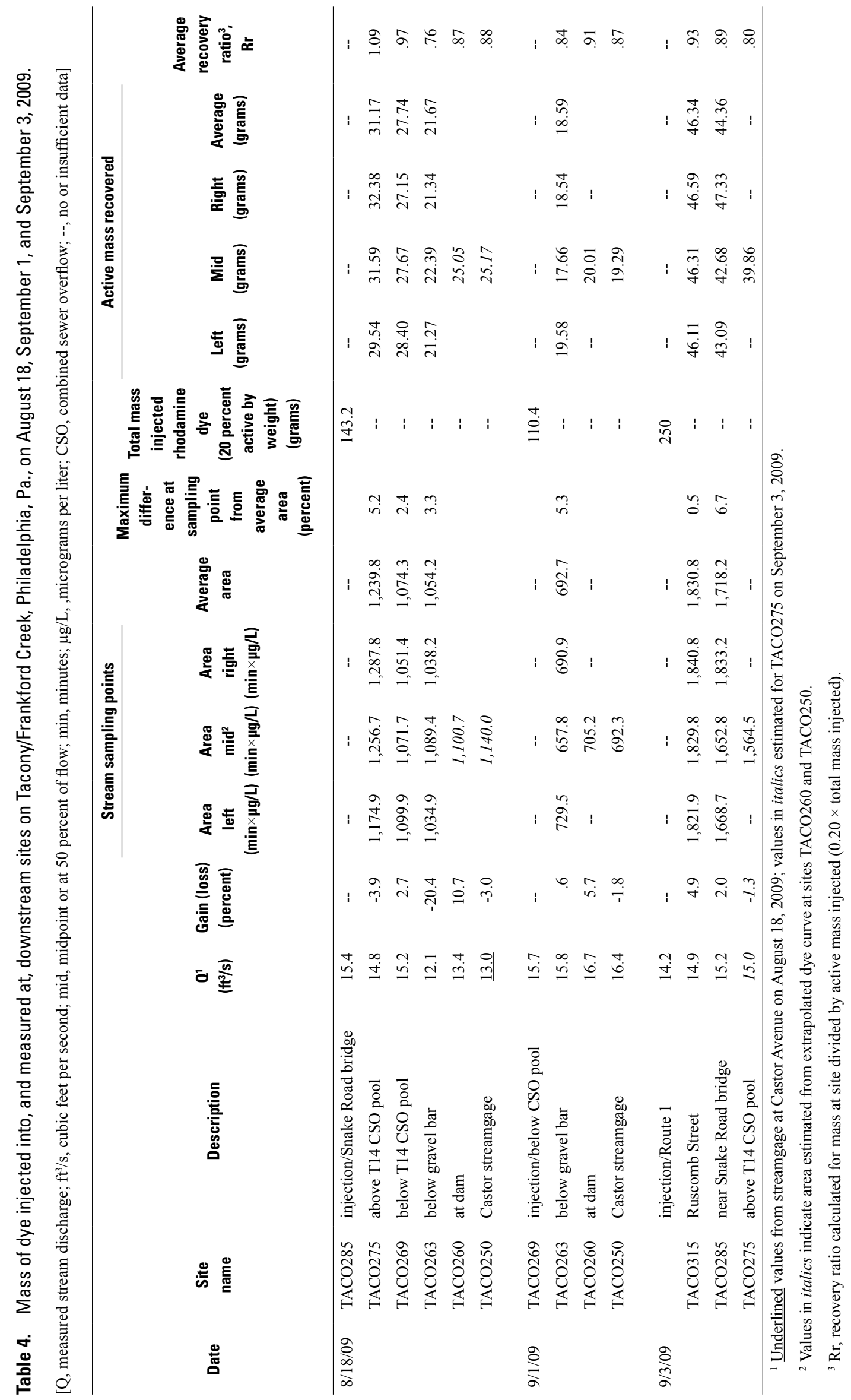




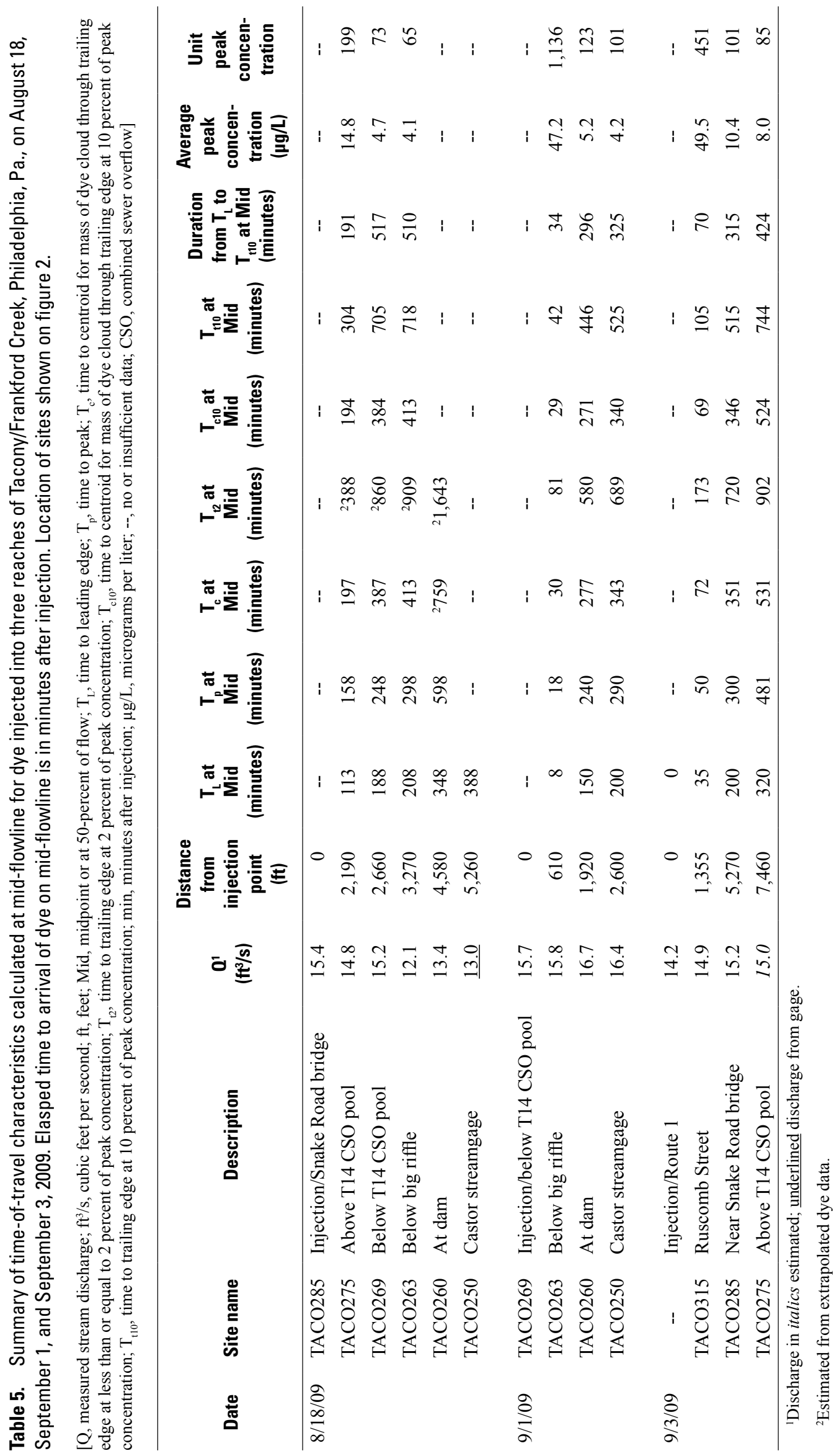


be applied, within limitations, for pollutant or solute loads at different stream discharges. By using unit concentration, only variations due to longitudinal dispersion remain (Hubbard and others, 1982). Unit concentrations obtained during one discharge, therefore, are applicable for a range of discharges limited only by the rate at which the longitudinal dispersion of the dye varies. The unit-peak concentration is determined using the following formula (Jobson, 1996), making adjustments to the measured peak-dye concentration values to determine the conservative unit-peak concentration according to Kilpatrick (1993).

$$
C_{u p}=\frac{Q C_{p k}}{W_{t} R_{r}}=\frac{Q C_{p k}}{W_{r}}
$$

where,

$C_{\text {up }}$ is the unit-peak concentration, in micrograms per liter per pound times cubic feet per second;

$Q \quad$ is the discharge, in cubic feet per second at the cross section;

$C_{\mathrm{pk}} \quad$ is the measured peak concentration;

$R_{\mathrm{r}} \quad$ is the recovery ratio, calculated by dividing the weight of dye recovered $\left(W_{\mathrm{r}}\right)$ by the weight of dye injected $\left(W_{\mathrm{t}}\right)$ or $R_{\mathrm{r}}=W_{\mathrm{r}} / W_{\mathrm{t}}$;

$W_{\mathrm{t}} \quad$ is the weight, in pounds, of tracer dye injected, and

$W_{r} \quad$ is weight, in pounds, of the dye recovered at each cross section calculated by multiplying discharge, $Q$, in cubic feet per second at the cross section, by the area under the time-concentration curve, $A_{c}$, in micrograms per liter multiplied by hours or $W_{r}=Q A_{c}$. (The area under the time-concentration curve is calculated by multiplying the concentration of each sample by the time interval for each sample and summing the sub-areas.)

Note that in equation 1, the measured peak concentration divided by the recovery ratio represents the conservative peak concentration or the peak concentration obtainable had no dye losses occurred.

Dispersion can be depicted as the decrease in unit-peak concentration of a conservative constituent plotted against elapsed time and represents the scattering of particles in water that affects the concentration of a constituent as it is transported downstream. The dye tracer used (rhodamine WT) is a relatively conservative constituent, but adjustments were made to account for dye that was lost due to natural decay or absorbed by stream sediment. Unit concentrations (for a conservative constituent) were computed using measured peak dye concentrations adjusted by the dye-recovery ratio (eqn. 1). The attenuation of the resulting adjusted unit concentrations define longitudinal dispersion of the peak concentration as the dye cloud moves downstream or as time elapses.
The dispersion efficiency of a stream to disperse a solute is defined by the rate of change in unit-peak concentration with respect to elapsed time (Kilpatrick and Taylor, 1986). A simple equation has been developed to relate solute injected and the resulting concentration as a function of time since injection, which theoretically describes the dispersion efficiency of a stream. The general form of the equation is:

$$
C_{u p}=a T^{-b},
$$

where,
$a$ is the unit-peak concentration, at an elapsed time of 1 hour;
$T$ is the time, in hours since injection; and
$b \quad$ is a coefficient.

When plotted on a log-log plot, the slope of the regression line relating elapsed time since injection to peak $(T)$ and unit-concentration $\left(C_{u p}\right)$ is the coefficient $b$ in equation 2 and its value is an indicator of dispersion efficiency. Steeper slopes of the regression line, or larger values of $b$, correspond to larger amounts of longitudinal dispersion.

The log-log plot of unit peak concentration in relation to time to peak for this study shows that peak concentrations decline nearly linearly as time to peak increases (fig. 15). Scatter in points indicates variation in the ability of a particular reach to disperse a solute. The T14 pool serves as a retention and mixing area that attenuates peak concentrations more than other reaches in the study. The slope of the unit-peak regression curve for the study area (fig. 15) is -0.879 , with an $r^{2}$ value of about 0.94 , similar to the slope of -0.887 determined in a regression of unit concentrations for a wide range of rivers in the United States (422 cross sections in 60 rivers) (Jobson, 1996).

In the ideal case of complete vertical and lateral mixing in steady flow in a straight uniform channel, the value for $b$ is 0.5 (slope of -0.5 for log-log plot) (Kilpatrick, 1993). According to Kilpatrick (1993), values of $b$ greater than 1.0 (slope of -1.0 ) indicate incomplete lateral mixing and values equal to 1.5 (slope of -1.5) indicate incomplete lateral and vertical mixing and (or) short distances. The slope on the log-log plot from point TACO275 to TACO269 (fig. 15) is -2.23 , and thus, $b$ is greater than 1.5, which, using these criteria (Kilpatrick, 1993), would indicate incomplete mixing in the T14 pool.

The T14 pool, just below sampling site TACO275, had a notable effect on dye concentrations downstream. As expected, the dye cloud was attenuated substantially and its duration increased, as indicated by data (fig. 14) collected at the outlet of the T14 pool (site TACO269). In addition, dye coming out of this pool behaved erratically, appearing to be stripped off in pulses, as evidenced by fluctuations in concentrations (fig. 11). Use of the dispersion equation developed from data collected at other sampling locations in the study would underestimate dispersion through the pool. The T14 pool has a greater ability to disperse a solute than other sections of the study reaches, as indicated by the greater than predicted change in unit-peak 


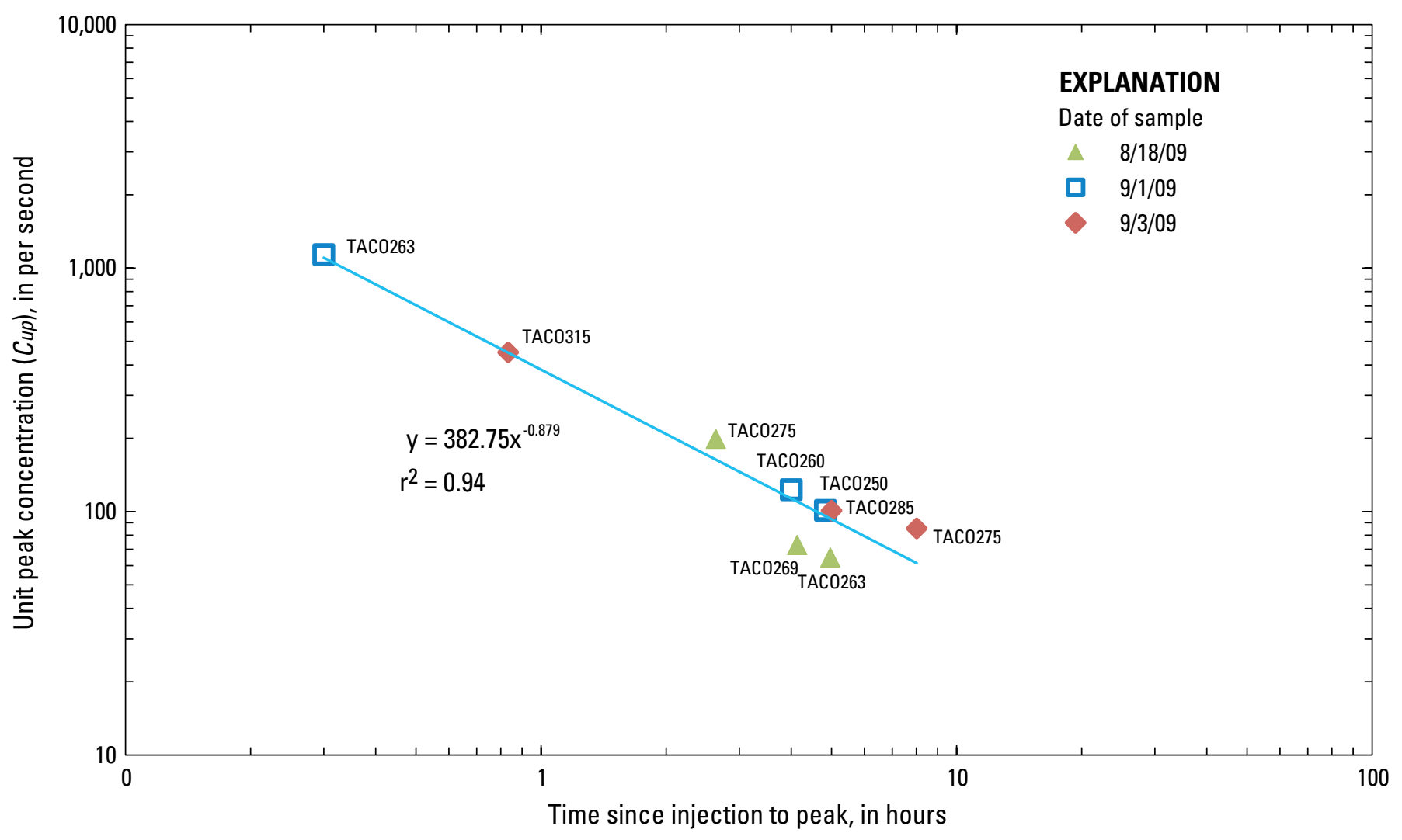

Figure 15. Unit-peak concentration in relation to time elapsed since dye injection at selected sampling sites, Tacony/Frankford Creek, Philadelphia, Pa., during dye study conducted on August 18, September 1, and September 3, 2009.

concentration between the two sites bounding the pool (upstream site TACO275 and downstream site TACO269). The greater relative amount of dispersion in this sub-reach is also indicated by the increased lag in the trailing edge of dye cloud as it passed through the T14 pool (fig. 11). In order to better define transport characteristics of the T14 pool, dye sampling at multiple verticals and at depth would be required. Conditions of 3-dimensional dispersion probably affect movement of dye through the pool, and data contained in this report do not adequately describe the exact processes of advection and dispersion at this location.

\section{Determination of Reaeration Coefficients}

The CRI method (Kilpatrick and others, 1989) selected for this study to determine reaeration coefficients requires that gas be injected at a constant rate over a sufficiently long period to establish plateau gas concentrations downstream. This gas-injection period is equal to or greater than the traveltime for the tail of the dye cloud, as defined by 2 percent of the peak concentration, to reach a stream site. Gas injection was started at least 45 minutes before dye was injected to ensure gas concentration plateaus had developed by the time of sampling. Rates of gas injection throughout each day are listed in appendix 3 .
Reaeration coefficients (table 6) were calculated for reaches on the basis of the time-of-travel for the dye cloud centroid $\left(t_{c}\right)$ to pass between two sites, as described by Kilpatrick and others (1989). For example, the incremental traveltime between site TACO275 and TACO269 is calculated by subtracting the traveltime since injection at the downstream site TACO269 from traveltime since injection at the upstream site, or $\mathrm{t}_{\mathrm{c}}=\mathrm{T}_{\text {cTAC0269 }}-\mathrm{T}_{\text {cTACO275 }}$. Initial rate coefficients are calculated for the degassing of propane $\left(\mathrm{K}_{\mathrm{p}}\right)$, then corrected for stream temperature to $20^{\circ} \mathrm{C}$, and converted to reaeration coefficients for oxygen $\left(\mathrm{K}_{2}\right)$. The value used for the correction of stream temperature was the average stream temperature recorded by the water-quality sondes over the period of the dye and gas injection at each site on each day (from about 6 a.m. to about 8 p.m.).

On August 18, 2009, dye sampling at the downstream sites TACO260 and TACO250 was terminated before the full dye cloud had passed these sites because of field conditions. However, a few gas samples were collected at TACO260 to provide estimates of how much gas might be exchanged in that reach. Because the gas concentrations had not yet reached a plateau at TACO260, the reaeration coefficient $\left(\mathrm{K}_{2}\right)$ presented in table 6 for the reach ending at the dam is higher than the actual coefficient for that day but provides an upper range for reaeration rates in this reach. The apparent difference in gas concentrations between the upstream (TACO263) and 
Table 6. Reaeration coefficients determined from field method (constant rate injection of tracer gas) for study sub-reaches in Tacony/ Frankford Creek, Philadelphia, Pa., on August 18, September 1, and September 3, 2009.

[Q, stream discharge; $\mathrm{ft}^{3} / \mathrm{s}$, cubic feet per second; $\mu \mathrm{g} / \mathrm{L}$, micrograms per liter; $\mathrm{t}_{\mathrm{c}}$, centroid time-of-travel for sub-reach; deg $\mathrm{C}$, degrees Celcius; $\mathrm{K}_{\mathrm{T}}$, reaeration coefficient for propane gas at stream temperature; $\mathrm{K}_{2}$ at $20 \mathrm{deg} \mathrm{C}$, reaeration coeffcient for oxygen at 20 degrees Celsius, --, no data; <, less than; >, greater than]

\begin{tabular}{|c|c|c|c|c|c|c|c|c|}
\hline & $\underset{\left(\mathrm{ft}^{3} / \mathrm{s}\right)}{\mathbf{0}}$ & $\begin{array}{c}\text { Plateau } \\
\text { concen- } \\
\text { tration of } \\
\text { propane } \\
(\mu \mathrm{g} / \mathrm{L})\end{array}$ & $\begin{array}{c}\text { Traveltime of } \\
\text { dye centroid } \\
\left(T_{c}\right) \\
\text { (minutes } \\
\text { since } \\
\text { injection) }\end{array}$ & $\begin{array}{l}\text { Incremental } \\
\text { traveltime of } \\
\text { centroid }\left(\mathbf{t}_{\mathbf{c}}\right)^{1} \\
\text { for sub-reach } \\
\text { (minutes) }\end{array}$ & $\begin{array}{c}\text { Propane gas } \\
\text { reaeration } \\
\text { coefficient, } \\
\mathbf{K}_{\mathrm{T}^{\prime}} \\
\text { (units per } \\
\text { hour) }\end{array}$ & $\begin{array}{c}\text { Average } \\
\text { stream } \\
\text { temperature } \\
(\operatorname{deg} C)\end{array}$ & $\begin{array}{c}\text { Oxygen gas } \\
\text { reaeration } \\
\text { coefficient, } \\
\mathrm{K}_{2} \text { at } 20 \text { deg } \mathrm{C} \\
\text { (units per } \\
\text { hour) }\end{array}$ & $\begin{array}{c}\text { Measure- } \\
\text { ment error } \\
\text { for } K_{2} \\
\text { (percent) }\end{array}$ \\
\hline \multicolumn{9}{|c|}{ Day 1 - August 18, 2009} \\
\hline TACO 263 & 12 & 44 & 413 & 26 & 1.863 & 25.1 & 2.293 & 12.2 \\
\hline TACO260 & 13.3 & ${ }^{3}>30$ & 759 & 346 & $<.0487$ & 25.5 & $<.0594$ & $>35.6$ \\
\hline TACO 250 & 14 & -- & -- & -- & -- & -- & -- & \\
\hline \multicolumn{9}{|c|}{ Day 3 - September 1, 2009} \\
\hline \multicolumn{9}{|c|}{ Day 4 - September 3, 2009} \\
\hline TACO315 & 14.91 & 88 & 72 & 72 & -- & -- & -- & -- \\
\hline TACO 285 & 15.18 & 30.6 & 351 & 279 & .23 & 19.6 & .323 & 9.3 \\
\hline TACO 275 & 15 & 24.2 & 531 & 179 & .083 & 19.5 & .117 & 40.3 \\
\hline
\end{tabular}

${ }^{1}$ Traveltime for sub-reach is time for dye cloud centroid to travel from nearest upstream to downstream sampling site, where centroid calculated for mass of dye cloud through the 2 percent trailing edge.

${ }^{2}$ Measurement error, E, from Parker and Gay (1987) calculated as $\mathrm{E}=\mathrm{Re} /\left[\mathrm{K}_{\mathrm{T}} *\left(\mathrm{~T}_{\mathrm{cd}}-\mathrm{T}_{\mathrm{cu}}\right)\right]$, where Re is the relative combined error of gas-concentration and discharge measurements estimated at 10 percent and $\mathrm{T}_{\mathrm{cd}}$ and $\mathrm{T}_{\mathrm{cu}}$ are traveltimes to upstream and downstream sites, respectively.

${ }^{3}$ Gas concentrations had not reached plateau values at TACO260 when terminated because of field conditions; however, samples collected at that time indicate plateu concentrations would be greater than $30 \mu \mathrm{g} / \mathrm{L}$.

downstream (TACO260) ends of the reach, used to calculate reaeration coefficients, is higher than if the gas plateau concentrations had developed at TACO260.

On September 1, 2009, the propane gas injection rate declined in the late afternoon because the gas amounts in the 100-lb cylinder were declining (see appendix 3 ). However, most gas samples were collected before the decline in injected gas, which began at about 1 p.m., would have reached the sampling sites from the injection site. The traveltimes for gas as determined by the centroid of the dye cloud, were about $0.5,4.5$, and 5.67 hours from injection to the sampling sites TACO263, TACO260, and TACO250, respectively (table 5), and thus the decline of gas at 1 p.m. would have reached each site at about 1:30 p.m., 5:30 p.m., and 6:40 p.m., respectively. Gas samples were collected from noon to $2 \mathrm{p} . \mathrm{m}$. at site TACO250, from 3:30 to 5:30 p.m. at site TACO260, and from 4:40 to 6:40 p.m. at site TACO250. The reaeration coefficient $\left(\mathrm{K}_{2}\right)$ calculated for the reach between TACO263 and TACO260 on September 1 is similar but slightly lower, as can be expected, than the estimated rate coefficient calculated for the incomplete study on August 18, 2009.

Overall, the oxygen reaeration coefficients $\left(\mathrm{K}_{2}\right)$ ranged from a minimum of 0.043 to a maximum of 2.29 units per hour. The lowest reaeration rate (smallest coefficient) is for the sub-reach affected by backwater conditions from the dam, from sites TACO263 to TACO260 (fig. 2). Despite having the lowest estimated stream velocity, the reaeration coefficient of 0.136 unit per hour in the sub-reach including the T14 pool and ending at the head of the gravel bar (site TACO269) is nearly three times that of the sub-reach ending at the dam (site TACO260), perhaps because of the large surface area relative to sub-reach length of the T14 pool.

The highest reaeration rate (largest coefficient, 2.29 units per hour) is for the steep sub-reach that starts at the head of the gravel bar (site TACO269) and travels through the gravel bar in multiple channels before converging to a single channel (near site TACO263). The next highest rate (coefficient of 0.62 unit per hour) is for the sub-reach from the dam to the Castor streamgage (sites TACO260 to TACO250), where 
aeration is enhanced by hydraulic structures (notch and weir). The most natural sub-reach in the study area characterized by a series of riffles and pools, from Ruscomb Street (site TACO315) to just below the Snake Road bridge (site TACO285), had the third highest reaeration rate (coefficient of 0.32 unit per hour).

Estimates of measurement error determined by a method described by Parker and Gay (1987) for the calculated reaeration coefficients ranged from 9.3 to 78.6 percent (table 6). Generally, the estimated measurement error as a percentage is larger for small values than for large values of reaeration coefficients.

The reaeration coefficients listed in table 6 were determined for streamflow conditions similar to annual mean base flow of $15 \mathrm{ft}^{3} / \mathrm{s}$ but were higher than mean base flows for the months of August and September. Reaeration rates will vary on the basis of flow conditions and other factors, and therefore, the reaeration coefficients determined in summer 2009 should be used with caution in application to other flow regimes. In an Illinois study where reaeration coefficients were determined for the same five reaches on three different dates with different base flows, the range in coefficient values for each reach typically was within a factor of three, although the range was as high as an order of magnitude for one reach (Turner, 1996).

\section{Comparison to Reaeration Coefficients Determined by Other Methods}

Several studies, such as Parker and Gay (1987), have compared theoretical reaeration rates calculated using equations with various variables such as stream slope, depth, and velocity to rates determined by field methods using tracer gases. Findings from the Parker and Gay (1987) study indicate theoretical rates calculated using the equation by Owens and others (1964) compared to rates determined from field methods using tracer gases had the lowest absolute error of 53 percent for low gradient streams with slopes less than $0.002 \mathrm{ft} / \mathrm{ft}$. Kilpatrick and others (1989) suggest use of the Owens and others (1964) equation to estimate reaeration coefficients for streams with slopes less than $0.003 \mathrm{ft} / \mathrm{ft}$ and the Tsivoglou and Neal (1976) equation for streams with slopes greater than $0.003 \mathrm{ft} / \mathrm{ft}$.

Owens and others (1964): $\mathrm{K}_{2}=0.906\left(\mathrm{v}^{0.67} / \mathrm{d}^{1.85}\right)$

Tsivoglou and Neal (1976):

$$
\mathrm{K}_{2}=0.054(\mathrm{dh} / \mathrm{dt})
$$

where

$\mathrm{K}_{2} \quad$ is reaeration coefficient, in units per hours;

$\mathrm{v}$ is mean stream velocity, in cubic feet per second;

$\mathrm{d}$ is stream depth, in feet;

dh is change in elevation over reach, in feet; and

dt is traveltime of centroid over reach, in hours.
The theoretical equations typically assume natural channels or simple channel conditions that are not present in the artificially altered reaches of Frankford Creek from the T14 CSO through the dam in the golf course. Comparison of reaeration coefficients calculated from the theoretical equations, such as equations 3 and 4 , to those calculated from the field tracer-gas method is useful to determine where differences from the two approaches differ most. Reaeration coefficients using the two theoretical equations (eqns. 3 and 4) suggested by Kilpatrick and others (1989) were calculated on the basis of reach traveltimes and stream velocities determined from field methods using tracer gases in Tacony/ Frankford Creek in August and September 2009 (table 7). The slope of sub-reaches in the Tacony/Frankford Creek study ranged from 0.0008 to $0.0109 \mathrm{ft} / \mathrm{ft}$. The Owens and others (1964) equation was used for all but two sub-reaches that ended at sites TACO263 and TACO250 (table 8). Theoretical reaeration coefficients were all less than the coefficients determined from field methods using tracer gases and ranged from -10 to -81 percent. The smallest percentage differences (-10 to -13 percent) between coefficients determined by theoretical and field methods were for the upper sub-reaches (between sites TACO315 and TACO285 and TACO275) that are the most natural stream channels in the Tacony/Frankford Creek study. These results suggest that theoretical methods may provide reasonable estimates only for natural sections of the creek.

An alternative approach to estimating reaeration coefficients from DO concentration data was presented by Chapra and DiToro (1991), with solutions to type-fitting curves developed by McBride (2002). This approach uses the time offset of daily maximum (or minimum) DO concentrations from solar noon to estimate the reaeration coefficients. Data on daily maximum DO concentrations at each sampling site in the Tacony/Frankford Creek reaeration study were available from the four-parameter water-quality sondes that continuously recorded values at 5-minute intervals or, at the Castor streamgage, at 30-minute intervals (fig. 10).

Reaeration coefficients calculated using the time offset of the DO concentration generally were similar or smaller in various amounts than those calculated by the CRI tracer-gas method for all sub-reaches, with differences from the tracergas method coefficients ranging from about 1 to 99 percent (table 8), except the sub-reach ending at the dam in the golf course, site TACO260, for which the DO method coefficient was larger than the tracer-gas method coefficient. The reaeration coefficient calculated using the time offset of the DO concentration was nearly identical to the reaeration coefficient determined by the field CRI tracer-gas method for the uppermost sub-reach in the study, from TACO315 to TACO285 (table 8). This uppermost sub-reach is the most natural rifflepool sequence in the study area. The coefficients estimated by the DO and tracer-gas methods were within \pm 12 percent for the sub-reach from site TACO285 to TACO275 in the upstream study section (table 8), which although free-flowing appears to have backwater caused perhaps by alteration of 
Table 7. Comparison of reaeration coefficients $\left(\mathrm{K}_{2}\right)$ calculated by theoretical equations based on stream characteristics and coefficients determined by field methods using tracer gases for sub-reaches of Tacony/Frankford Creek, Philadelphia, Pa., August and September 2009. Values for variables used to calculate $\mathrm{K}_{2}$ are shown for sub-reaches.

[ft, feet; NAVD, North American Vertical Datum of 1988; min, minutes; v, velocity; ft/s, feet per second; Q, stream discharge; ft $\mathrm{ft}^{3} / \mathrm{s}$, cubic feet per second; $\mathrm{ft}^{2}$, square feet; d, depth; w, width; --, no data or not applicable]

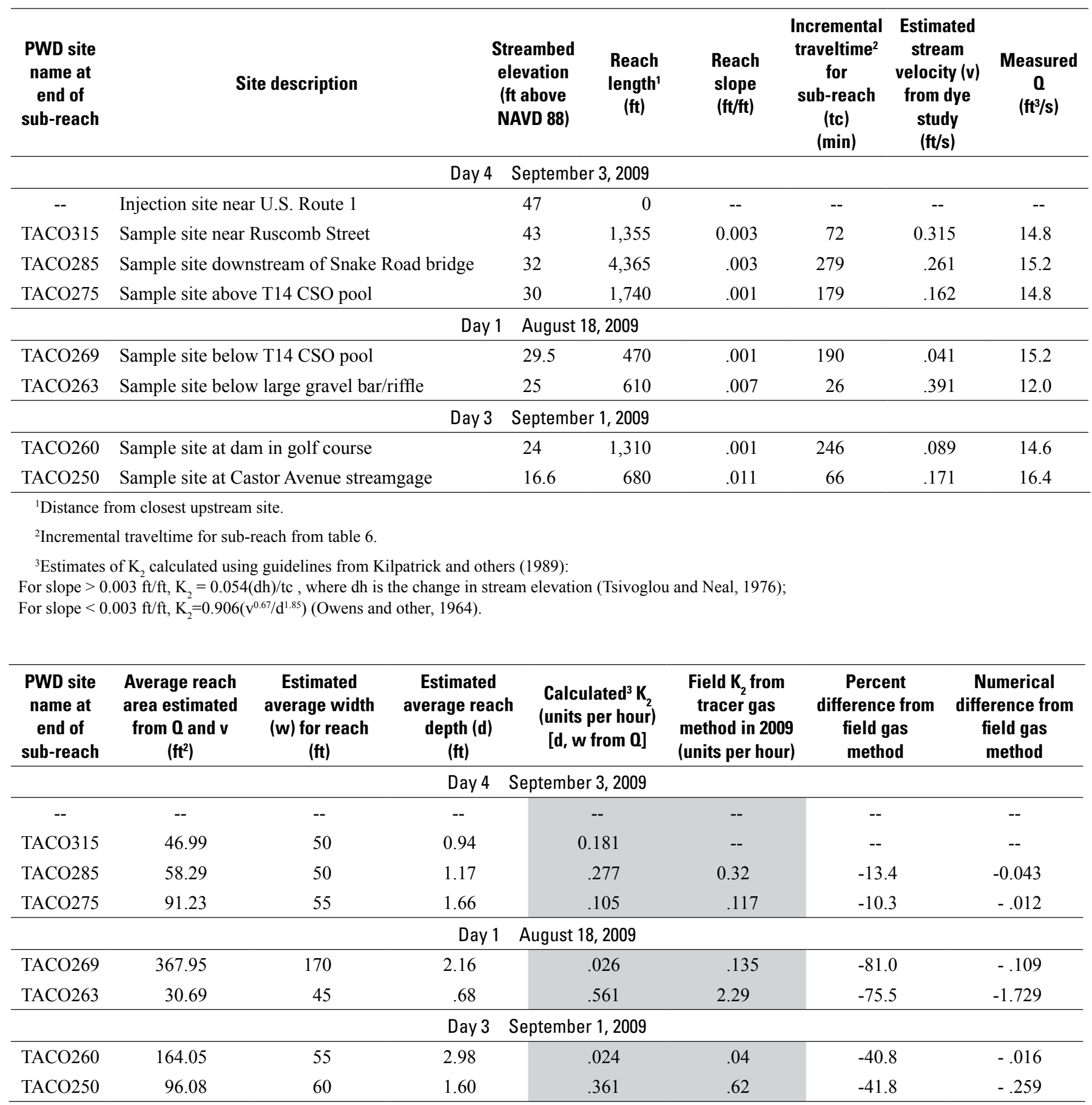




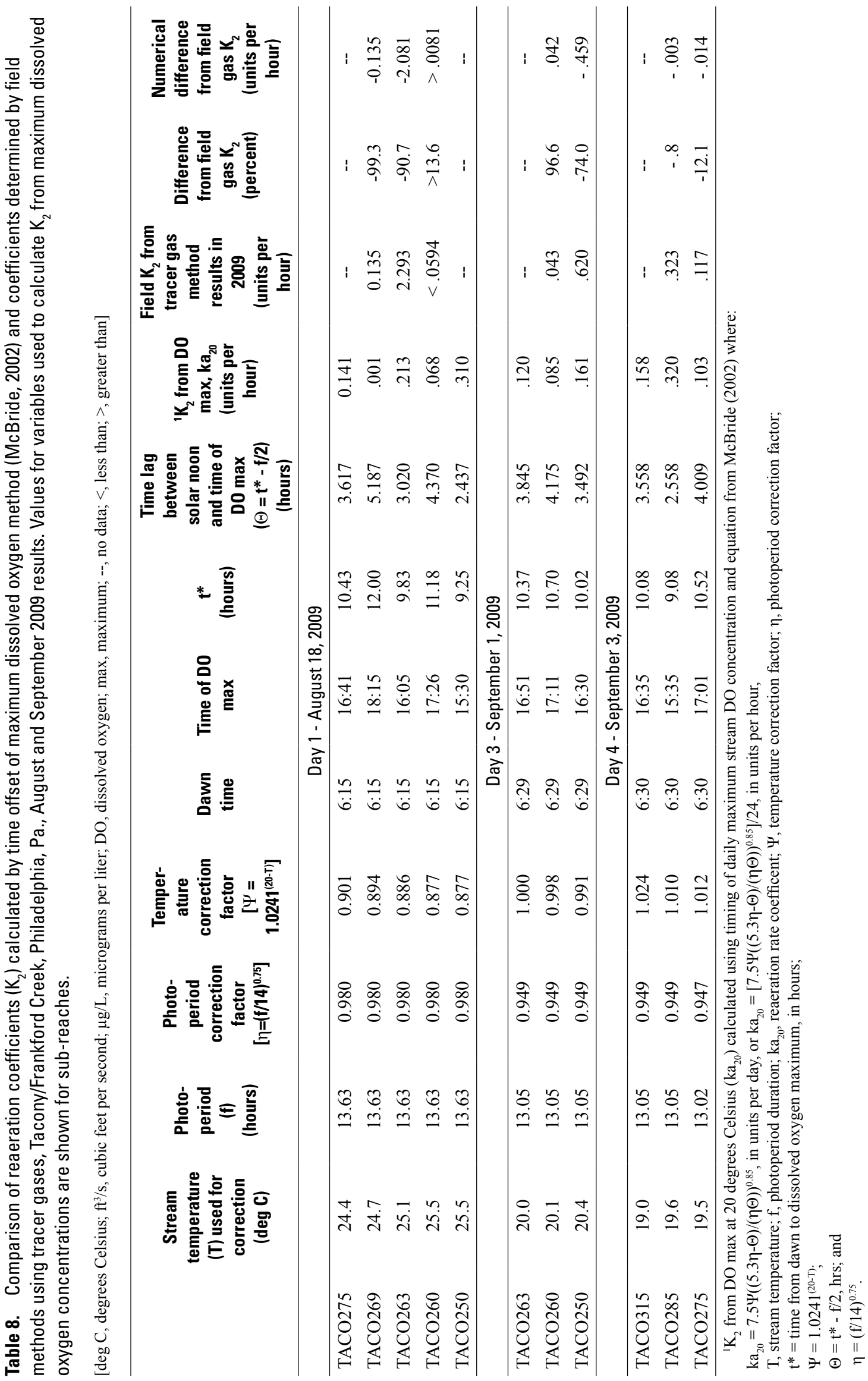


stream gradients near the T14 pool. For another sub-reach with backwater conditions, from site TACO263 to site TACO260 in the downstream study section, the difference between the relatively low reaeration coefficients calculated by both the DO and tracer-gas methods was greater than 13 percent on August 18 and was 96.4 percent on September 3 (tables 6, 8). The differences between $\mathrm{K}_{2}$ determined by different methods for the reach ending at TACO260 on August 3, 2009, can only be estimated as a greater than value (13 percent) because the $\mathrm{K}_{2}$ determined from the tracer-gas method (given as a less than value in tables 6 and 8) was from propane gas concentrations that had not yet reached stable plateau values when samples were collected at that site. The two methods differed most in terms of the magnitude and percentage difference in the sub-reaches where large amounts of aeration occurred because of hydraulic structures (TACO260 to TACO250), channel roughness and steep gradient (TACO269 to TACO263), or large stream surface areas (TACO275 to TACO269). The comparison of the two methods suggest that the time offset of DO maximum method may provide reasonable estimates of reaeration coefficients for relatively natural channels under steady base-flow conditions.

\section{Stream Methane Concentrations}

In addition to the tracer gas, propane, the gas analysis also included methane, ethene, and ethane, of which only methane was measured in concentrations above a few micrograms per liter. Methane, thought to occur naturally or because of ongoing processes in the stream, was measured in concentrations ranging from 6.6 to $78 \mu \mathrm{g} / \mathrm{L}$, and concentrations were greatest in sub-reaches that included relatively deeper pools. Methane concentrations, like the injected tracer gas propane, decreased from upstream to downstream in sub-reaches with relatively large rates of reaeration but increased from upstream to downstream in reaches with relatively low rates of reaeration, deeper slower water, and pools (fig. 16).

During site reconnaissance in July 2009, bubbles of unidentified gas were observed to rise from stream sediments in pools. For the two of three sub-reaches that were sampled on two study days, average methane concentrations were greater in August than in September (fig. 17), perhaps because higher temperatures in August promoted larger production of methane within the stream. Both of these sub-reaches, ending at sites TACO275 and TACO260, include sections where sediment has accumulated and sections that are more than $2.5 \mathrm{ft}$ in depth. Methane concentrations also may vary throughout the day, as indicated by samples collected at different times at one site, TACO260. On August 18, 2009, at this site, the methane concentration in a background gas sample collected at 11:30 a.m. was $78 \mu \mathrm{g} / \mathrm{L}$ and in later samples collected from 7:00 to 7:40 p.m. concentrations ranged from 38.1 to $49.5 \mu \mathrm{g} / \mathrm{L}$. 


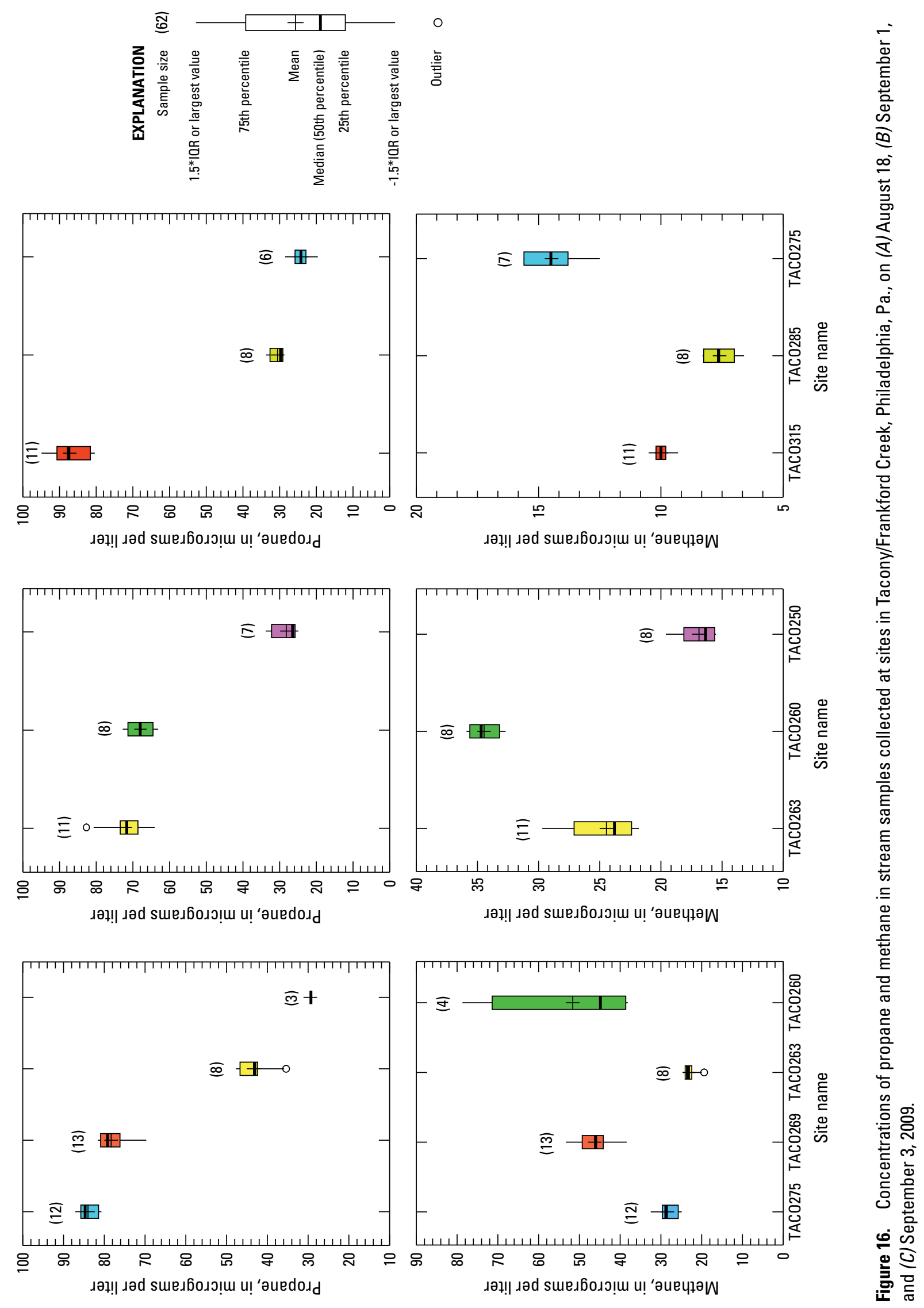




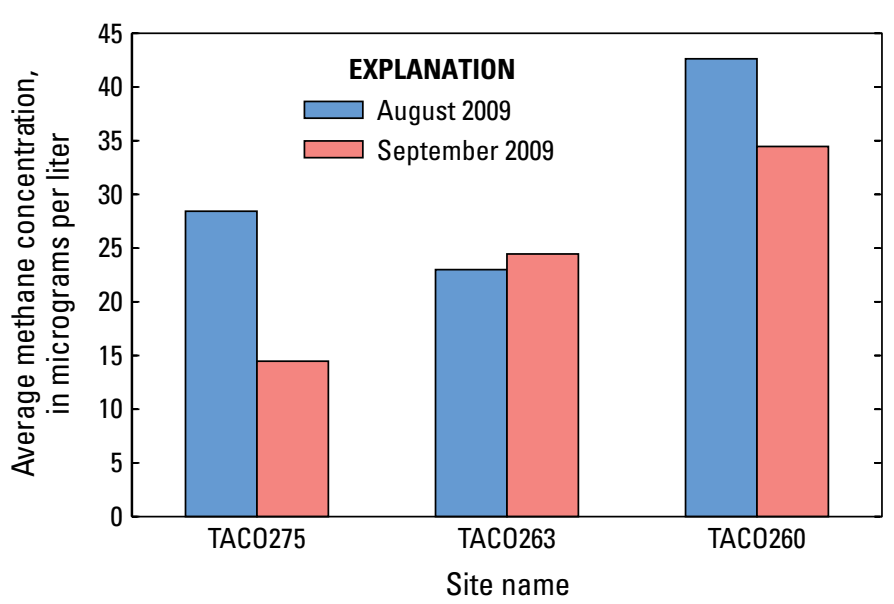

Figure 17. Average methane concentrations in samples collected at three sites on Tacony/Frankford Creek, Philadelphia, $\mathrm{Pa}$., in both August and September 2009.

\section{Summary and Conclusions}

A study to determine time-of-travel, dispersion, and oxygen reaeration rate coefficients on a 2-mi reach of Tacony/ Frankford Creek, Philadelphia, Pa., was conducted by the U.S. Geological Survey (USGS) in cooperation with the Philadelphia Water Department (PWD) in 2009. Several combined sewer overflows (CSOs) discharge to the study reach, which has been altered by man-made structures and ends at a USGS streamgage, Frankford Creek at Castor Avenue (station 01467087). Above this streamgage, Tacony/Frankford Creek drains a 30 -square mile urbanized area underlain principally by metamorphic bedrock in Philadelphia and Montgomery Counties. Water-quality concerns in parts of the study reach include low concentrations of dissolved oxygen (less than $4 \mathrm{mg} / \mathrm{L}$ ), especially during low-flow conditions in the warm summer months as documented by water-quality sensors operated by the PWD at the USGS streamgage at Castor Avenue. The study results will provide the city of Philadelphia with information necessary to help manage water-quality problems and calibrate a water-quality model.

The study reach extended from Roosevelt Boulevard (U.S. Route 1) to the streamgage at Castor Avenue. The upper half of the study reach above a CSO designated T14 by PWD is the most natural, and the lower half of the study reach is most affected by man-made structures. Natural channel widths in the Tacony/Frankford Creek are about 50 to $60 \mathrm{ft}$, and stream depths range from 1 to $2.5 \mathrm{ft}$ under base-flow conditions. The T14 CSO, one of the largest in Philadelphia, is at the mouth of the now buried former Wingohocking Creek, about 2,600 ft upstream from the streamgage at Castor Avenue, and discharges all stormwater from the 13- $\mathrm{mi}^{2}$ Wingohocking Creek drainage area to Tacony/Frankford Creek. A large pool has developed at the T14 CSO outfall and is up to $12 \mathrm{ft}$ in depth and about an acre in surface area. From the T14 CSO to the Castor Avenue streamgage, the stream channel has been straightened and dammed. The dam, about $680 \mathrm{ft}$ upstream from the Castor Avenue streamgage, creates backwater. Below the notch in the dam, the stream flows over a concrete apron to a weir and through a channel with a natural substrate bottom and concrete walls to the streamgage. Slopes ranged from 0.001 to $0.01 \mathrm{ft} / \mathrm{ft}$ for selected sub-reaches in the study area.

Time-of-travel, dispersion, and reaeration coefficients were determined from injection and monitoring of dye and gas tracers during base-flow conditions in August and September 2009 on three sub-reaches of the study reach. A single injection of rhodamine WT dye and constant rate injection of propane gas were made at the top of each of the three sub-reaches followed by sampling at three or more sites downstream. The time-of-travel and dispersion characteristics were determined from dye samples collected at each site and later analyzed in the laboratory under controlled conditions. Propane was used as a conservative tracer to directly measure oxygen reaeration.

Determination of traveltimes to the centroid of the dye cloud were needed for calculation of the reaeration coefficients. In addition, the time-of-travel and dispersion characteristics determined for this study may have other applications, such as use in understanding transport and attenuation of potential contaminants or other constituents in the stream. Results of the dye study in Tacony/Frankford Creek indicate that traveltimes were affected by the presence of man-made structures, such as the large scour pool developed at the outfall of the T14 CSO and the dam, both of which reduce stream velocities. Mean stream velocities during the dye-tracer tests ranged from $0.04 \mathrm{ft} / \mathrm{s}$ through the $\mathrm{T} 14$ pool to a maximum of $0.39 \mathrm{ft} / \mathrm{s}$. Relative to other sub-reaches in the study area, a larger amount of dispersion appears to occur as the stream passes through the T14 pool. The dispersion efficiency was determined through the relation of normalized unit-concentrations and time elapsed to peak and may be of use in waterquality modeling.

Reaeration coefficients ranged from 0.043 to 2.29 units per hour. Man-made structures appear to result in both reducing and elevating natural reaeration rates. The lowest reaeration rate (smallest reaeration coefficient of 0.043 unit per hour) is for the sub-reach affected by backwater conditions, such as reduced velocities and increased depths, above the dam. The sub-reach including the T14 pool has the lowest average estimated stream velocity in the study area but has a reaeration coefficient of 0.136 unit per hour that is nearly three times that of the sub-reach ending at the dam. The reaeration coefficient for the sub-reach with the T14 pool may be larger than that for the sub-reach ending at the dam because of the large surface area of the T14 pool or other factors associated with flow through the T14 pool. The highest reaeration rate (largest coefficient of 2.29 units per hour) is for the sub-reach that starts at the head of the gravel bar at the outlet of the T14 pool and travels through the gravel bar in multiple channels before converging to a single channel. This sub-reach had the highest velocities and shallowest depths of those selected for study. The next highest reaeration rate (coefficient of 0.62 unit 
per hour) is for the sub-reach from the dam to the streamgage at Castor Avenue, where aeration is enhanced by hydraulic structures (notch and weir) that generate turbulence. The most natural sub-reach characterized by a series of riffles and pools had the third highest reaeration rate (coefficient of 0.32 unit per hour) and is in the upstream part of the study area.

Reaeration coefficients determined from the field tracergas method for this study were compared to those determined from theoretical equations using variables such as stream depth and velocity and a method using the timing of maximum stream concentrations of dissolved oxygen. Values of reaeration coefficients determined by the tracer-gas method were 2 to 10 times higher than values determined by the two alternate methods for most sub-reaches hydraulically affected by man-made structures. Generally, the differences between values determined from the three methods were least (less than 15 percent) for the most natural sub-reaches of the study area above the T14 CSO and greatest (up to about 100 percent) for reaches most affected by man-made structures. Results of the comparison suggest that reaeration coefficients may be estimated using theoretical equations or the dissolved-oxygen method with relatively small error only for relatively natural reaches and not for reaches with unusual physical characteristics or those affected by man-made structures.

In addition to the tracer gas, propane, the gas analysis also included methane, ethane, and ethene, of which only methane was measured in concentrations above a few micrograms per liter. Methane, thought to occur naturally or because of ongoing processes in the stream, was measured in concentrations ranging from 6.6 to $78 \mu \mathrm{g} / \mathrm{L}$; concentrations were greatest in sub-reaches dominated by pools. Methane concentrations, like the injected tracer gas propane, decreased from upstream to downstream in sub-reaches with relatively large rates of reaeration but increased from upstream to downstream in reaches with relatively low rates of reaeration, deeper slower water, and deeper pools.

\section{Acknowledgments}

This study could not have been completed without the assistance and cooperation of Jason Cruz, Josef Kardos, Lance Butler, and others of the Philadelphia Water Department (PWD), the staff and volunteers of the Juniata Golf Course, and U.S. Geological Survey (USGS) personnel David Galeone, Arthur Lilienthal, Leif Olson, Andrew Reif, Anthony Trease, and Kirk White. In addition, technical support in the design of samplers was provided by Philip Bird of USGS and public relations and field assistance was provided by Hannah Hamilton and Mary Sites Robic of USGS. Permission to conduct the study in Tacony Creek Park was provided by the Fairmount Park Commission, whose staff member Jacqueline Olson provided background information useful for planning and logistics. The essential contribution of Gene Parker of USGS to the design and planning of the study is gratefully acknowledged.

\section{References Cited}

Bascom, Florence, Clark, W.B., Darton, N.H., Knapp, G.N., Kuemmel, H.B., Miller, B.L., and Salisbury, R.D., 1909, Philadelphia folio, Norristown, Germantown, Chester, and Philadelphia, Pennsylvania-New Jersey-Delaware: U.S. Geological Survey Folios of the Geologic Atlas 162, scale 1:62,500.

Berg, T.M., Edmunds, W.E., Geyer, A.R., and others, comps., 1980, Geologic map of Pennsylvania (2nd ed.): Pennsylvania Geological Survey, 4th ser., Map 1, scale 1:250,000, 3 sheets.

Bosbyshell, Howell, 2006, Bedrock geologic map of the Chester Valley and Piedmont portion of the Germantown, Malvern, Norristown, and Valley Forge quadrangles, Chester, Delaware, Montgomery, and Philadelphia Counties, Pennsylvania: Pennsylvania Geological Survey, 4th ser., Open-File Report OFBM 06-04.0, 16 p., Portable Document Format (PDF).

Chapra, S.C., and DiToro, D.M., 1991, Delta method for estimating primary production, respiration, and reaeration in streams: Journal of Environmental Engineering, v. 117, no. 5, p. 640-655.

Chirico, P.G., and Epstein, J.B., 2000, Geographic information systems analysis of topographic change in Philadelphia, Pennsylvania, during the last century: U.S. Geological Survey Open-File Report 00-224, one CD-ROM, map scale 1:24,000.

Cleveland, W.S., and Devlin, S.J., 1988, Locally weighted regression-An approach to regression analysis by local fitting: Journal of the American Statistical Association, v. 83, p. 596-610.

Hubbard, E.F., Kilpatrick, F.A., Martens, L.A., and Wilson, J.F., Jr., 1982, Measurement of time of travel and dispersion in streams by dye tracing: U.S. Geological Survey Techniques of Water-Resources Investigations, book 3, chap. A9, $44 \mathrm{p}$.

Hudson, Felisa, 2004, Standard operating procedureSample preparation and calculations for dissolved gas analysis in water samples using a GC headspace equilibration technique: U.S. Environmental Protection Agency, RSKSOP-175, Revision No. 2, May 2004, 14 p. accessed March 16, 2010, at http://www.epa.gov/ne/into/testmethods/ pdfs/RSKsop175v2.pdf.

Jobson, H.E., 1996, Predicion of traveltime and longitudinal dispersion in streams: U.S. Geological Survey WaterResources Investigations Report 96-4013, 69 p. 
Kilpatrick, F.A., 1993, Simulation of soluble waste transport and buildup in surface waters using tracers: U.S. Geological Survey Techniques of Water-Resources Investigations, book 3, chap. A20, 37 p.

Kilpatrick, F.A., and Cobb, E.D., 1985, Measurement of discharge using tracers: U.S. Geological Survey Techniques of Water-Resources Investigations, book 3, chap. A16, 52 p.

Kilpatrick, F.A., Rathburn, R.E., Yotsukura, N., Parker, G.W., and DeLong, L.L., 1989, Determination of stream reaeration coefficients by use of tracers: U.S. Geological Survey Techniques of Water-Resources Investigations, book 3, chap. A18, $52 \mathrm{p}$.

Kilpatrick, F.A., and Taylor, K.R., 1986, Applications of dispersion data: Water Resources Bulletin of the American Water Resources Association, v. 22, no. 4, p. 537-548.

Kilpatrick, F.A., and Wilson, J.F., Jr., 1989, Measurement of time of travel in streams by dye tracing: U.S. Geological Survey Techniques of Water-Resources Investigations, book 3, chap. A9, 27 p.

Knappen Engineering Company, 1947, Report on flood control Frankford Creek: City of Philadelphia, Pennsylvania, $102 \mathrm{p}$.

Levine, A., 2004, The sad history of Frankford Creek: accessed January 25, 2010, at http://www.phillyh2o.org/ backpages/FrankfordCreek_SadHistory.htm.

McBride, G.B., 2002, Calculating stream reaeration coefficients from oxygen profiles: Journal of Environmental Engineering, v. 128, p. 384-386.

Miles, C. E., and Whitfield, T. G. ,compilers, 2001, Bedrock geology of Pennsylvania: Pennsylvania Geological Survey, 4th ser., dataset, scale 1:250,000.

National Oceanic and Atmospheric Administration, 2010, Historical weather facts for the Philadelphia/Mount Holly, NJ Forecast Area: National Weather Service Forecast Office, accessed March 23, 2010, at http://www.erh.noaa.gov/phi/ hist_phi.html.

Owens, Moriasis, Edwards, R.W., and Gibbs, J.W., 1964, Some reaeration studies in streams: Oxford, England, International Journal of Air and Water Pollution, v. 8, no. 8/9, p. $469-486$.

Parker, G.W., and Gay, F.B., 1987, A procedure for estimating reaeration coefficients for Masachussets streams: U.S. Geological Survey Water-Resources Investigations Report 86-4111, 34 p.

Peltier, Jon, 2009, LOESS Utility-Awesome Update: Peltier Tech Blog, Peltier Technical Services, Inc., accessed December 21, 2009, at http://peltiertech.com/WordPress/ loess-utility-awesome-update/.
Pennsylvannia Department of Environmental Protection, 2009, Water quality standards: Pennsylvania Code, Title 25, chap. 93, accessed June 1, 2010, at http://www.pacode.com/ secure/data/025/chapter93/chap93toc.html.

Rantz, S.E., and others, 1982, Measurement and computation of streamflow-Volume 1, Measurement of stage and discharge: U.S. Geological Survey Water-Supply Paper 2175, p. 1-284.

Ruhl, K.J., 1987, Mean velocity, longitudinal dispersion, and reaeration characteristics of selected streams in the Kentucky River Basin: U.S. Geological Survey WaterResources Investigations Report 87-4179, 61 p.

Sauer, V.B., and Meyer, R.W., 1992, Determination of error in individual discharge measurements: U.S. Geological Survey Open-File Report 92-144, 21 p.

Sevon, W.D., comp., 2000, Physiographic provinces of Pennsylvania (4th ed.): Pennsylvania Geological Survey, 4th ser., Map 13, Scale 1:2,000,000.

Sloto, R.A., and Crouse, M.Y., 1996, HYSEP_-A computer program for streamflow hydrograph separation and analysis: U.S. Geological Survey Water-Resources Investigations Report 96-4040, 46 p.

Tsivoglou, E.C., and Neal, L.A., 1976, Tracer measurement of stream reaeration, Part 3 , Predicting the reaeration capacity of inland streams: Journal of the Water Pollution Control Federation, v. 48, no. 12, p. 2669-2689.

Turner, M.J., 1996, Traveltime and reaeration characteristics for Salt Creek Basin in Northeastern Illinois, June-October 1995: U.S. Geological Survey Open-File Report 95-771, $14 \mathrm{p}$.

Wagner, R.J., Boulger, R.W., Oblinger, C.J., and Smith, B.A., 2006, Guidelines and standard procedures for continuous water-quality monitors: station operation, record computation, and data reporting: U.S. Geological Survey Techniques and Methods 1-D3, $51 \mathrm{p}$.

White, K.E., and Kratzer, T.W., 1993, Determination of traveltime in the Delaware River, Hancock, New York to the Delaware Water Gap by use of a conservative dye tracer: U.S. Geological Survey Water-Resources Investigations Report 93-4203, 54 p.

Wilson, J.F., Jr., Cobb, E.D., and Kilpatrick, F.A., 1986, Fluorometric procedures for dye tracing: U.S. Geological Survey Techniques of Water-Resources Investigations, book 3, chap. A12, 34 p. 


\section{Appendix 1.-Continuous Water-Quality Data}

Table 1-1. Minimum, maximum, mean, and median values for chemical and physical properties measured by water-quality monitors during the period of dye tracing in Frankford Creek, Philadelphia, Pa. on August 18, September 1, and September 3, 2009.

Table 1-2. Chemical and physical properties measured by water-quality monitors during the period of dye tracing in Tacony/Frankford Creek, Philadelphia, Pa. on August 18, September 1, and September 3, 2009. 
Table 1-1. Minimum, maximum, mean, and median values for chemical and physical properties measured by water-quality monitors during the period of dye tracing in Frankford Creek, Philadelphia, Pa. on August 18, September 1, and September 3, 2009.

[USGS, U.S. Geological Survey; ${ }^{\circ} \mathrm{C}$, degrees Celsius; $\mu \mathrm{S} / \mathrm{cm}$, microsiemens per centimter; FNU, Formazin Nephelometric units; mg/L, milligrams per liter; --, no data]

\begin{tabular}{|c|c|c|c|c|c|c|c|c|c|c|}
\hline \multirow{2}{*}{ Site } & \multirow{2}{*}{$\begin{array}{c}\text { USGS } \\
\text { station } \\
\text { number }\end{array}$} & \multirow{2}{*}{ Date } & \multirow{2}{*}{$\begin{array}{l}\text { Time } \\
\text { period }\end{array}$} & $\begin{array}{c}\text { Temper- } \\
\text { ature } \\
\left({ }^{\circ} \mathrm{C}\right)\end{array}$ & $\begin{array}{c}\text { Specific } \\
\text { Conduc- } \\
\text { tance } \\
(\mu \mathrm{S} / \mathrm{cm})\end{array}$ & $\begin{array}{c}\text { Sonde } \\
\text { depth } \\
\text { or gage } \\
\text { height }^{1} \\
\text { (feet) }\end{array}$ & $\mathbf{p H}$ & $\begin{array}{c}\text { Turbidity } \\
\text { (FNU) }\end{array}$ & $\begin{array}{l}\text { Dissolved } \\
\text { oxygen } \\
\text { saturation } \\
\text { (percent) }\end{array}$ & $\begin{array}{c}\text { Dissolved } \\
\text { oxygen } \\
\text { concen- } \\
\text { tration } \\
\text { (mg/L) }\end{array}$ \\
\hline & & & & $\begin{array}{c}\text { Min } \\
\text { Max } \\
\text { Range } \\
\text { Mean } \\
\text { Median }\end{array}$ & $\begin{array}{c}\text { Min } \\
\text { Max } \\
\text { Range } \\
\text { Mean } \\
\text { Median }\end{array}$ & $\begin{array}{c}\text { Min } \\
\text { Max } \\
\text { Range } \\
\text { Mean } \\
\text { Median }\end{array}$ & $\begin{array}{c}\text { Min } \\
\text { Max } \\
\text { Range } \\
\text { Mean } \\
\text { Median }\end{array}$ & $\begin{array}{c}\text { Min } \\
\text { Max } \\
\text { Range } \\
\text { Mean } \\
\text { Median }\end{array}$ & $\begin{array}{c}\text { Min } \\
\text { Max } \\
\text { Range } \\
\text { Mean } \\
\text { Median }\end{array}$ & $\begin{array}{c}\text { Min } \\
\text { Max } \\
\text { Range } \\
\text { Mean } \\
\text { Median }\end{array}$ \\
\hline \multirow[t]{4}{*}{ TACO275 } & 014670866 & $8 / 18 / 2009$ & 7:11 a.m. & 23.3 & 634 & 2.24 & 7.28 & 0.9 & 58.8 & 5.0 \\
\hline & & & to $7: 51$ p.m. & 25.5 & 640 & 2.37 & 7.75 & 10.1 & 110.9 & 9.1 \\
\hline & & & & 2.2 & 6 & .13 & .47 & 9.2 & 52.1 & 4.1 \\
\hline & & & & $\underline{24.4}$ & $\underline{637}$ & $\underline{2.29}$ & $\underline{7.55}$ & $\underline{1.3}$ & $\underline{90.5}$ & $\underline{7.5}$ \\
\hline & & & to $8: 05$ p.m. & 25.4 & 640 & 1.89 & 7.67 & 4.9 & 102.7 & 8.4 \\
\hline & & & & 1.6 & 7 & .12 & .44 & 3.6 & 53.4 & 4.3 \\
\hline & & & & $\underline{24.7}$ & $\underline{636}$ & $\underline{1.84}$ & $\underline{7.47}$ & $\underline{1.7}$ & $\underline{80.4}$ & $\underline{6.7}$ \\
\hline & & & & 24.8 & 635 & 1.84 & 7.47 & 1.6 & 84.9 & 7.0 \\
\hline \multirow[t]{5}{*}{ TACO263 } & 014670868 & $8 / 18 / 2009$ & 8:30 a.m. & 23.9 & 657 & 1.67 & 7.33 & 1.0 & 77.1 & 6.5 \\
\hline & & & to $7: 55$ p.m. & 25.7 & 671 & 2.26 & 7.72 & 7.3 & 106.1 & 8.6 \\
\hline & & & & 1.9 & 14 & .59 & .39 & 6.3 & 29.0 & 2.2 \\
\hline & & & & $\underline{25.1}$ & $\underline{666}$ & $\underline{2.11}$ & $\underline{7.56}$ & $\underline{1.5}$ & $\underline{93.2}$ & $\underline{7.7}$ \\
\hline & & & & 25.4 & 666 & 2.15 & 7.58 & 1.3 & 94.8 & 7.8 \\
\hline \multirow[t]{5}{*}{ TACO 250} & 01467087 & $8 / 18 / 2009$ & 6:30 a.m. & 24.1 & 614 & 1.57 & 6.9 & -- & -- & 2.8 \\
\hline & & & to $8: 00$ p.m. & 26.6 & 622 & 1.59 & 7.5 & -- & -- & 8.8 \\
\hline & & & & 2.5 & 8 & .02 & .6 & -- & -- & 6.0 \\
\hline & & & & $\underline{25.5}$ & $\underline{617}$ & $\underline{1.58}$ & $\underline{7.3}$ & -- & -- & $\underline{6.9}$ \\
\hline & & & & 25.9 & 616 & 1.58 & 7.4 & -- & -- & 7.9 \\
\hline \multirow[t]{5}{*}{ TACO263 } & 014670868 & $9 / 1 / 2009$ & 6:45 a.m. & 18.9 & 533 & 1.55 & 7.43 & 0.4 & 80.0 & 7.4 \\
\hline & & & to $7: 55$ p.m. & 20.7 & 588 & 1.62 & 7.71 & 2.9 & 104.0 & 9.3 \\
\hline & & & & 1.8 & 55 & .07 & .28 & 2.5 & 24.0 & 1.9 \\
\hline & & & & $\underline{20.0}$ & $\underline{564}$ & $\underline{1.58}$ & $\underline{7.60}$ & .7 & $\underline{95.2}$ & $\underline{8.6}$ \\
\hline & & & & 20.2 & 566 & 1.58 & 7.62 & .5 & 98.4 & 8.9 \\
\hline
\end{tabular}


Table 1-1. Minimum, maximum, mean, and median values for chemical and physical properties measured by water-quality monitors during the period of dye tracing in Frankford Creek, Philadelphia, Pa. on August 18, September 1, and September 3, 2009.—Continued

[USGS, U.S. Geological Survey; ${ }^{\circ} \mathrm{C}$, degrees Celsius; $\mu \mathrm{S} / \mathrm{cm}$, microsiemens per centimter; FNU, Formazin Nephelometric units; mg/L, milligrams per liter; --, no data]

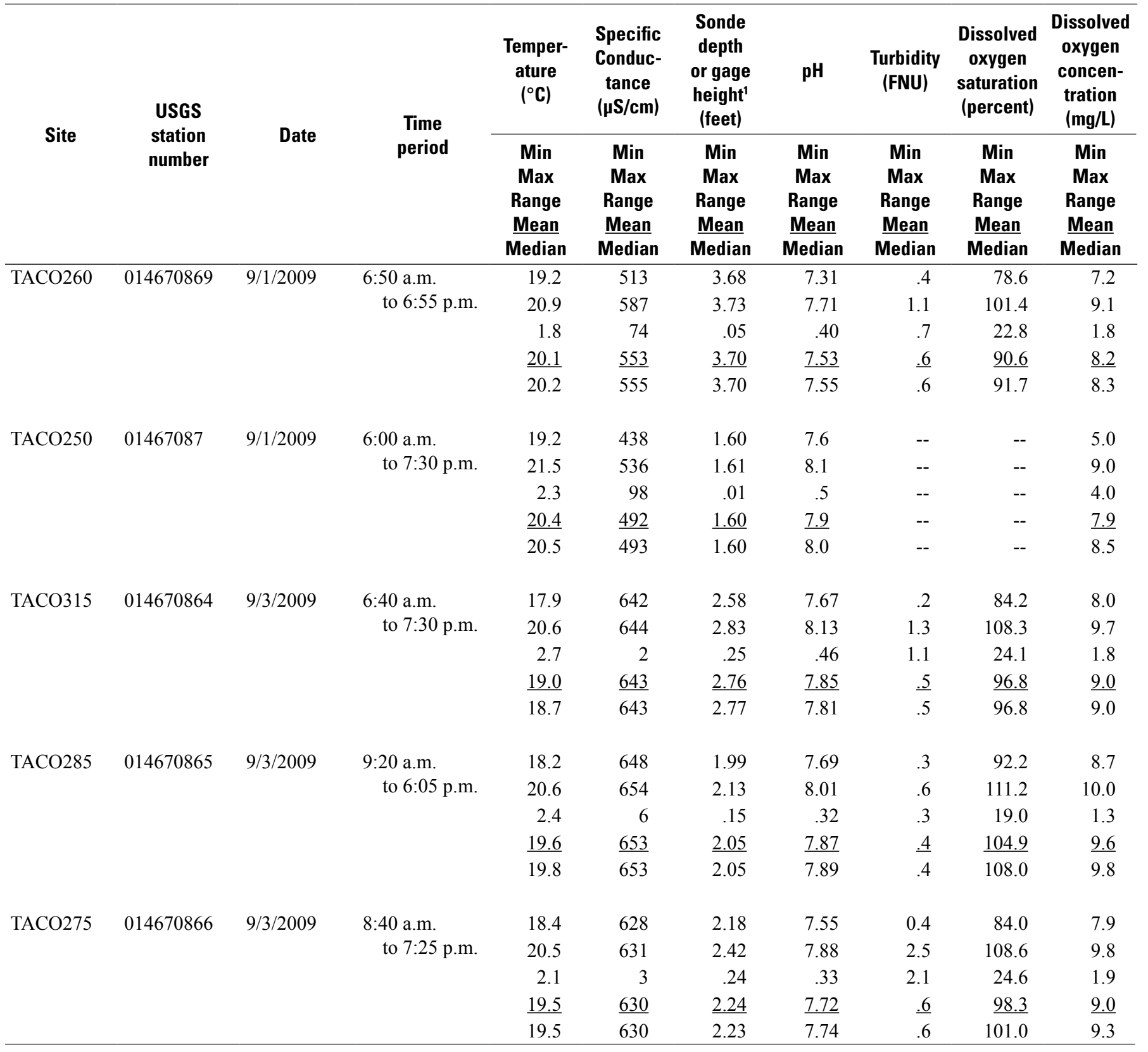

${ }^{1}$ Sonde depth was depth of water over water-quality sonde placed in stream at each site except for TACO250, where gage height is recorded as USGS streamgage 01467087. 
Table 1-2. Chemical and physical properties measured by water-quality monitors during the period of dye tracing in Tacony/ Frankford Creek, Philadelphia, Pa. on August 18, September 1, and September 3, 2009.

$\left[{ }^{\circ} \mathrm{C}\right.$, degrees Celsius; $\mu \mathrm{S} / \mathrm{cm}$, microsiemens per centimter; $\mathrm{mg} / \mathrm{L}$, milligrams per liter; FNU, Formazin Nephelometric units; USGS, U.S. Geological Survey; ,-- no data]

\begin{tabular}{|c|c|c|c|c|c|c|c|c|c|}
\hline Site & Date & Time & $\begin{array}{c}\text { Temper- } \\
\text { ature } \\
\left({ }^{\circ} \mathrm{C}\right)\end{array}$ & $\begin{array}{c}\text { Specific } \\
\text { conduc- } \\
\text { tance } \\
(\mu \mathrm{S} / \mathrm{cm})\end{array}$ & $\begin{array}{c}\text { Sonde depth } \\
\text { or gage } \\
\text { height }^{1} \\
\text { (feet) }\end{array}$ & pH & $\begin{array}{l}\text { Dissolved } \\
\text { oxygen } \\
\text { (DO) } \\
\text { concen- } \\
\text { tration } \\
\text { (mg/L) }\end{array}$ & $\begin{array}{c}\text { DO } \\
\text { saturation } \\
\text { (percent) }\end{array}$ & $\begin{array}{c}\text { Turbidity } \\
\text { (FNU) }\end{array}$ \\
\hline \multicolumn{10}{|c|}{ USGS station number 014670866} \\
\hline \multirow{31}{*}{ TACO275 } & & $7: 21: 04$ & 23.5 & 634 & 2.37 & 7.34 & 5.4 & 63.6 & 1.7 \\
\hline & & $7: 26: 04$ & 23.4 & 634 & 2.37 & 7.35 & 5.4 & 63.7 & 1.2 \\
\hline & & $7: 31: 04$ & 23.4 & 634 & 2.37 & 7.35 & 5.4 & 63.6 & 1.2 \\
\hline & & $7: 36: 04$ & 23.4 & 634 & 2.37 & 7.35 & 5.4 & 63.8 & 1.2 \\
\hline & & $7: 41: 04$ & 23.4 & 634 & 2.37 & 7.35 & 5.4 & 64.0 & 1.2 \\
\hline & & $8: 01: 04$ & 23.4 & 634 & 2.37 & 7.35 & 5.5 & 64.4 & 1.2 \\
\hline & & $8: 06: 04$ & 23.4 & 634 & 2.36 & 7.34 & 5.5 & 64.5 & 1.2 \\
\hline & & $8: 11: 04$ & 23.4 & 634 & 2.36 & 7.35 & 5.5 & 64.6 & 1.2 \\
\hline & & $8: 16: 04$ & 23.4 & 635 & 2.36 & 7.35 & 5.5 & 65.0 & 1.1 \\
\hline & & $8: 21: 04$ & 23.4 & 634 & 2.37 & 7.35 & 5.5 & 65.1 & 1.3 \\
\hline & & $8: 26: 04$ & 23.4 & 634 & 2.36 & 7.34 & 5.5 & 65.0 & 1.2 \\
\hline & & $8: 31: 04$ & 23.4 & 634 & 2.36 & 7.35 & 5.6 & 65.4 & 1.2 \\
\hline & & $8: 36: 04$ & 23.4 & 635 & 2.36 & 7.35 & 5.6 & 65.5 & 1.2 \\
\hline & & $8: 41: 04$ & 23.3 & 634 & 2.36 & 7.35 & 5.6 & 65.9 & 1.1 \\
\hline & & $8: 46: 04$ & 23.3 & 634 & 2.36 & 7.35 & 5.6 & 66.2 & 1.1 \\
\hline & & $9: 26: 04$ & 23.3 & 634 & 2.35 & 7.36 & 5.9 & 68.7 & 1.0 \\
\hline & & $9: 31: 04$ & 23.3 & 634 & 2.35 & 7.36 & 5.9 & 68.8 & 1.1 \\
\hline & & $9: 36: 04$ & 23.3 & 634 & 2.35 & 7.36 & 5.9 & 69.1 & 1.0 \\
\hline & & $9: 41: 04$ & 23.3 & 634 & 2.35 & 7.37 & 5.9 & 69.6 & 1.1 \\
\hline & & $9: 46: 04$ & 23.3 & 634 & 2.35 & 7.37 & 6.0 & 69.9 & 1.1 \\
\hline & & $9: 51: 04$ & 23.3 & 634 & 2.36 & 7.37 & 6.0 & 70.3 & 1.0 \\
\hline & & $9: 56: 04$ & 23.3 & 634 & 2.36 & 7.38 & 6.0 & 71.0 & 1.1 \\
\hline & & 10:01:04 & 23.3 & 634 & 2.36 & 7.38 & 6.1 & 71.5 & 1.4 \\
\hline & & 10:06:04 & 23.3 & 634 & 2.36 & 7.38 & 6.1 & 71.9 & 1.2 \\
\hline & & 10:11:04 & 23.4 & 634 & 2.36 & 7.38 & 6.1 & 72.1 & 1.0 \\
\hline & & $10: 16: 04$ & 23.4 & 634 & 2.36 & 7.39 & 6.2 & 72.9 & 1.2 \\
\hline & & $10: 21: 04$ & 23.4 & 634 & 2.36 & 7.39 & 6.2 & 73.3 & 1.2 \\
\hline & & $10: 26: 04$ & 23.4 & 634 & 2.36 & 7.39 & 6.3 & 74.0 & 1.1 \\
\hline & & $10: 31: 04$ & 23.4 & 634 & 2.36 & 7.40 & 6.3 & 74.3 & 1.1 \\
\hline & & $10: 36: 04$ & 23.4 & 634 & 2.36 & 7.40 & 6.4 & 74.8 & 1.1 \\
\hline & & $10: 41: 04$ & 23.4 & 634 & 2.36 & 7.41 & 6.4 & 75.7 & 1.2 \\
\hline
\end{tabular}


Table 1-2. Chemical and physical properties measured by water-quality monitors during the period of dye tracing in Tacony/ Frankford Creek, Philadelphia, Pa. on August 18, September 1, and September 3, 2009.-Continued

$\left[{ }^{\circ} \mathrm{C}\right.$, degrees Celsius; $\mu \mathrm{S} / \mathrm{cm}$, microsiemens per centimter; mg/L, milligrams per liter; FNU, Formazin Nephelometric units; USGS, U.S. Geological Survey; ,-- no data]

\begin{tabular}{|c|c|c|c|c|c|c|c|c|c|}
\hline Site & Date & Time & $\begin{array}{c}\text { Temper- } \\
\text { ature } \\
\left({ }^{\circ} \mathrm{C}\right)\end{array}$ & $\begin{array}{c}\text { Specific } \\
\text { conduc- } \\
\text { tance } \\
(\mu \mathrm{S} / \mathrm{cm})\end{array}$ & $\begin{array}{c}\text { Sonde depth } \\
\text { or gage } \\
\text { height }^{1} \\
\text { (feet) }\end{array}$ & $\mathrm{pH}$ & $\begin{array}{l}\text { Dissolved } \\
\text { oxygen } \\
\text { (DO) } \\
\text { concen- } \\
\text { tration } \\
\text { (mg/L) }\end{array}$ & $\begin{array}{c}\text { DO } \\
\text { saturation } \\
\text { (percent) }\end{array}$ & $\begin{array}{c}\text { Turbidity } \\
\text { (FNU) }\end{array}$ \\
\hline & & $10: 46: 04$ & 23.4 & 634 & 2.36 & 7.41 & 6.5 & 76.0 & 1.3 \\
\hline & & $10: 51: 04$ & 23.5 & 634 & 2.36 & 7.41 & 6.5 & 76.5 & 1.2 \\
\hline & & $10: 56: 04$ & 23.5 & 634 & 2.36 & 7.42 & 6.5 & 77.0 & 1.4 \\
\hline & & 11:01:04 & 23.5 & 634 & 2.36 & 7.42 & 6.6 & 77.6 & 1.1 \\
\hline & & 11:06:04 & 23.5 & 634 & 2.36 & 7.42 & 6.6 & 78.2 & 1.2 \\
\hline & & 11:11:04 & 23.5 & 634 & 2.35 & 7.43 & 6.7 & 78.7 & 1.1 \\
\hline & & $11: 16: 04$ & 23.6 & 634 & 2.35 & 7.43 & 6.7 & 79.4 & 1.1 \\
\hline & & $11: 21: 04$ & 23.6 & 634 & 2.35 & 7.44 & 6.8 & 79.9 & 1.4 \\
\hline & & $11: 26: 04$ & 23.6 & 634 & 2.35 & 7.44 & 6.8 & 80.5 & 1.3 \\
\hline & & $11: 31: 04$ & 23.6 & 634 & 2.35 & 7.44 & 6.9 & 81.0 & 1.4 \\
\hline & & $11: 36: 04$ & 23.7 & 635 & 2.35 & 7.45 & 6.9 & 81.9 & 1.2 \\
\hline & & 11:41:04 & 23.7 & 634 & 2.35 & 7.45 & 7.0 & 82.2 & 1.2 \\
\hline & & $11: 46: 04$ & 23.7 & 634 & 2.35 & 7.47 & 7.1 & 83.6 & 1.2 \\
\hline & & $11: 51: 04$ & 23.7 & 635 & 2.35 & 7.47 & 7.1 & 83.8 & 1.1 \\
\hline & & $11: 56: 04$ & 23.8 & 635 & 2.34 & 7.47 & 7.1 & 84.3 & 1.0 \\
\hline & & $12: 01: 04$ & 23.8 & 635 & 2.34 & 7.48 & 7.2 & 85.5 & 1.2 \\
\hline & & $12: 06: 04$ & 23.8 & 635 & 2.34 & 7.49 & 7.3 & 86.0 & 1.0 \\
\hline & & $12: 11: 04$ & 23.8 & 635 & 2.34 & 7.49 & 7.3 & 86.6 & 1.0 \\
\hline & & $12: 16: 04$ & 23.8 & 635 & 2.34 & 7.49 & 7.3 & 86.5 & .9 \\
\hline & & $12: 21: 04$ & 23.9 & 635 & 2.34 & 7.50 & 7.4 & 88.0 & 1.0 \\
\hline & & $12: 26: 04$ & 23.9 & 635 & 2.34 & 7.51 & 7.5 & 88.5 & 1.1 \\
\hline & & $12: 31: 04$ & 23.9 & 636 & 2.34 & 7.51 & 7.5 & 89.1 & 1.0 \\
\hline & & $12: 36: 04$ & 24.0 & 635 & 2.34 & 7.52 & 7.5 & 89.6 & 1.1 \\
\hline & & $12: 41: 04$ & 24.0 & 635 & 2.33 & 7.52 & 7.6 & 90.4 & 1.0 \\
\hline & & $12: 46: 04$ & 24.0 & 635 & 2.33 & 7.52 & 7.6 & 90.6 & 1.0 \\
\hline & & $12: 51: 04$ & 24.1 & 635 & 2.33 & 7.53 & 7.7 & 91.7 & .9 \\
\hline & & $12: 56: 04$ & 24.1 & 635 & 2.33 & 7.54 & 7.7 & 92.2 & 1.0 \\
\hline & & 13:01:04 & 24.1 & 636 & 2.33 & 7.54 & 7.8 & 92.9 & .9 \\
\hline & & $13: 06: 04$ & 24.2 & 636 & 2.32 & 7.55 & 7.8 & 93.4 & 1.0 \\
\hline & & 13:11:04 & 24.2 & 636 & 2.32 & 7.56 & 7.9 & 94.0 & 1.0 \\
\hline & & $13: 16: 04$ & 24.2 & 636 & 2.32 & 7.56 & 7.9 & 94.4 & 1.0 \\
\hline & & $13: 21: 04$ & 24.3 & 636 & 2.31 & 7.57 & 8.0 & 96.0 & 1.0 \\
\hline & & $13: 26: 04$ & 24.3 & 636 & 2.31 & 7.58 & 8.1 & 96.5 & 1.0 \\
\hline & & $13: 31: 04$ & 24.3 & 636 & 2.31 & 7.57 & 8.1 & 96.5 & 1.2 \\
\hline & & $13: 36: 04$ & 24.3 & 636 & 2.31 & 7.58 & 8.1 & 97.1 & 1.0 \\
\hline & & $13: 41: 04$ & 24.4 & 636 & 2.31 & 7.60 & 8.2 & 98.2 & 1.0 \\
\hline & & $13: 46: 04$ & 24.5 & 636 & 2.31 & 7.61 & 8.3 & 99.4 & 1.5 \\
\hline & & $13: 51: 04$ & 24.4 & 637 & 2.31 & 7.60 & 8.3 & 99.1 & .9 \\
\hline & & $13: 56: 04$ & 24.5 & 637 & 2.31 & 7.60 & 8.3 & 99.5 & .9 \\
\hline & & 14:01:04 & 24.5 & 637 & 2.30 & 7.62 & 8.4 & 100.3 & 1.0 \\
\hline & & $14: 06: 04$ & 24.5 & 637 & 2.30 & 7.62 & 8.4 & 101.0 & 1.1 \\
\hline & & 14:11:04 & 24.6 & 637 & 2.29 & 7.63 & 8.5 & 101.8 & 1.1 \\
\hline & & $14: 16: 04$ & 24.6 & 637 & 2.29 & 7.64 & 8.5 & 102.0 & 1.0 \\
\hline & & $14: 21: 04$ & 24.7 & 637 & 2.29 & 7.64 & 8.5 & 102.5 & 1.1 \\
\hline
\end{tabular}


Table 1-2. Chemical and physical properties measured by water-quality monitors during the period of dye tracing in Tacony/ Frankford Creek, Philadelphia, Pa. on August 18, September 1, and September 3, 2009.-Continued

$\left[{ }^{\circ} \mathrm{C}\right.$, degrees Celsius; $\mu \mathrm{S} / \mathrm{cm}$, microsiemens per centimter; $\mathrm{mg} / \mathrm{L}$, milligrams per liter; FNU, Formazin Nephelometric units; USGS, U.S. Geological Survey; ,-- no data]

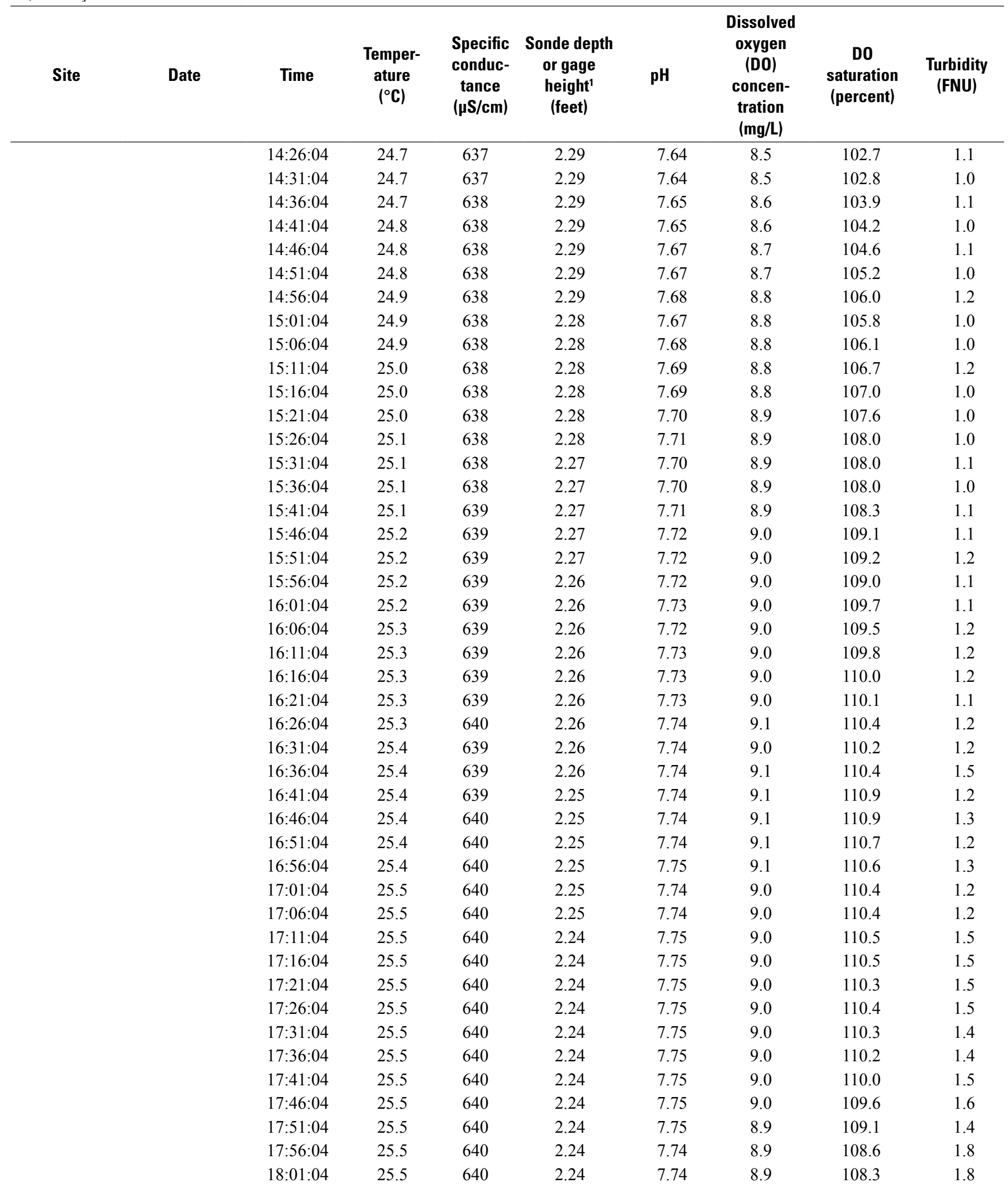


Table 1-2. Chemical and physical properties measured by water-quality monitors during the period of dye tracing in Tacony/ Frankford Creek, Philadelphia, Pa. on August 18, September 1, and September 3, 2009.-Continued

$\left[{ }^{\circ} \mathrm{C}\right.$, degrees Celsius; $\mu \mathrm{S} / \mathrm{cm}$, microsiemens per centimter; mg/L, milligrams per liter; FNU, Formazin Nephelometric units; USGS, U.S. Geological Survey; ,-- no data]

\begin{tabular}{|c|c|c|c|c|c|c|c|c|c|}
\hline Site & Date & Time & $\begin{array}{c}\text { Temper- } \\
\text { ature } \\
\left({ }^{\circ} \mathrm{C}\right)\end{array}$ & 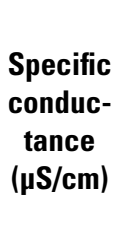 & $\begin{array}{l}\text { Sonde depth } \\
\text { or gage } \\
\text { height }^{1} \\
\text { (feet) }\end{array}$ & pH & $\begin{array}{l}\text { Dissolved } \\
\text { oxygen } \\
\text { (DO) } \\
\text { concen- } \\
\text { tration } \\
\text { (mg/L) }\end{array}$ & $\begin{array}{c}\text { DO } \\
\text { saturation } \\
\text { (percent) }\end{array}$ & $\begin{array}{c}\text { Turbidity } \\
\text { (FNU) }\end{array}$ \\
\hline & & 18:06:04 & 25.5 & 640 & 2.24 & 7.74 & 8.8 & 107.7 & 1.5 \\
\hline & & $18: 21: 04$ & 25.5 & 640 & 2.24 & 7.72 & 8.7 & 106.3 & 2.0 \\
\hline & & $18: 26: 04$ & 25.5 & 640 & 2.24 & 7.72 & 8.7 & 105.7 & 1.3 \\
\hline & & $18: 31: 04$ & 25.5 & 640 & 2.24 & 7.71 & 8.6 & 105.1 & 1.4 \\
\hline & & $18: 36: 04$ & 25.5 & 640 & 2.24 & 7.71 & 8.6 & 104.7 & 1.2 \\
\hline & & $18: 41: 04$ & 25.5 & 640 & 2.24 & 7.70 & 8.5 & 104.1 & 1.3 \\
\hline & & 19:01:04 & 25.4 & 640 & 2.24 & 7.68 & 8.4 & 102.3 & 1.2 \\
\hline & & 19:06:04 & 25.4 & 640 & 2.25 & 7.68 & 8.3 & 101.8 & 1.3 \\
\hline & & 19:11:04 & 25.4 & 640 & 2.24 & 7.67 & 8.3 & 101.4 & 1.3 \\
\hline & & $19: 16: 04$ & 25.4 & 640 & 2.25 & 7.67 & 8.3 & 100.9 & 1.5 \\
\hline & & $19: 21: 04$ & 25.4 & 640 & 2.25 & 7.67 & 8.2 & 100.2 & 1.4 \\
\hline & & $19: 26: 04$ & 25.4 & 640 & 2.24 & 7.66 & 8.2 & 99.6 & 1.3 \\
\hline & & $19: 31: 04$ & 25.4 & 640 & 2.25 & 7.65 & 8.1 & 99.3 & 1.5 \\
\hline & & $19: 36: 04$ & 25.4 & 640 & 2.24 & 7.65 & 8.1 & 98.7 & 1.3 \\
\hline & & 19:41:04 & 25.4 & 640 & 2.25 & 7.65 & 8.1 & 98.3 & 1.5 \\
\hline & & $19: 46: 04$ & 25.4 & 640 & 2.26 & 7.64 & 8.0 & 97.7 & 1.2 \\
\hline & & 19:51:04 & 25.4 & 640 & 2.27 & 7.63 & 8.0 & 97.1 & 1.2 \\
\hline & & $8: 00: 53$ & 23.8 & 634 & 1.89 & 7.25 & 4.4 & 51.7 & 2.0 \\
\hline & & $8: 05: 53$ & 23.8 & 633 & 1.89 & 7.25 & 4.4 & 51.7 & 2.0 \\
\hline & & $8: 10: 53$ & 23.8 & 634 & 1.89 & 7.26 & 4.4 & 52.3 & 1.9 \\
\hline & & $8: 15: 53$ & 23.8 & 634 & 1.89 & 7.25 & 4.4 & 51.8 & 2.1 \\
\hline & & $8: 20: 53$ & 23.8 & 634 & 1.89 & 7.25 & 4.3 & 51.3 & 1.9 \\
\hline & & $8: 25: 53$ & 23.7 & 633 & 1.89 & 7.25 & 4.4 & 51.5 & 2.0 \\
\hline & & $8: 30: 53$ & 23.7 & 634 & 1.89 & 7.25 & 4.3 & 51.0 & 2.0 \\
\hline & & $8: 35: 53$ & 23.7 & 633 & 1.89 & 7.24 & 4.3 & 50.4 & 2.1 \\
\hline & & $8: 40: 53$ & 23.7 & 633 & 1.89 & 7.24 & 4.2 & 50.1 & 2.8 \\
\hline & & $8: 45: 53$ & 23.8 & 634 & 1.89 & 7.23 & 4.2 & 49.3 & 2.5 \\
\hline & & $8: 50: 53$ & 23.8 & 633 & 1.89 & 7.24 & 4.3 & 50.5 & 3.1 \\
\hline & & $8: 55: 53$ & 23.8 & 633 & 1.89 & 7.24 & 4.2 & 49.8 & 2.0 \\
\hline & & 9:00:53 & 23.8 & 633 & 1.88 & 7.24 & 4.2 & 50.0 & 2.2 \\
\hline & & $9: 05: 53$ & 23.8 & 633 & 1.88 & 7.24 & 4.3 & 50.5 & 2.2 \\
\hline & & $9: 10: 53$ & 23.8 & 633 & 1.88 & 7.24 & 4.3 & 50.3 & 2.6 \\
\hline & & $9: 15: 53$ & 23.8 & 633 & 1.88 & 7.25 & 4.3 & 51.1 & 2.4 \\
\hline
\end{tabular}


Table 1-2. Chemical and physical properties measured by water-quality monitors during the period of dye tracing in Tacony/ Frankford Creek, Philadelphia, Pa. on August 18, September 1, and September 3, 2009.-Continued

$\left[{ }^{\circ} \mathrm{C}\right.$, degrees Celsius; $\mu \mathrm{S} / \mathrm{cm}$, microsiemens per centimter; $\mathrm{mg} / \mathrm{L}$, milligrams per liter; FNU, Formazin Nephelometric units; USGS, U.S. Geological Survey; ,-- no data]

\begin{tabular}{|c|c|c|c|c|c|c|c|c|c|}
\hline Site & Date & Time & $\begin{array}{l}\text { Temper- } \\
\text { ature } \\
\left({ }^{\circ} \mathrm{C}\right)\end{array}$ & $\begin{array}{c}\text { Specific } \\
\text { conduc- } \\
\text { tance } \\
(\mu \mathrm{S} / \mathrm{cm})\end{array}$ & $\begin{array}{c}\text { Sonde depth } \\
\text { or gage } \\
\text { height }^{1} \\
\text { (feet) }\end{array}$ & $\mathrm{pH}$ & $\begin{array}{c}\text { Dissolved } \\
\text { oxygen } \\
\text { (DO) } \\
\text { concen- } \\
\text { tration } \\
\text { (mg/L) }\end{array}$ & $\begin{array}{c}\text { DO } \\
\text { saturation } \\
\text { (percent) }\end{array}$ & $\begin{array}{c}\text { Turbidity } \\
\text { (FNU) }\end{array}$ \\
\hline & & $9: 20: 53$ & 23.8 & 634 & 1.88 & 7.25 & 4.4 & 51.9 & 2.0 \\
\hline & & $9: 35: 53$ & 23.8 & 634 & 1.88 & 7.27 & 4.5 & 53.7 & 2.0 \\
\hline & & $9: 40: 53$ & 23.8 & 634 & 1.88 & 7.27 & 4.6 & 54.1 & 2.0 \\
\hline & & $9: 45: 53$ & 23.9 & 634 & 1.88 & 7.27 & 4.6 & 54.2 & 1.9 \\
\hline & & $9: 50: 53$ & 23.9 & 634 & 1.88 & 7.27 & 4.7 & 55.2 & 2.1 \\
\hline & & $9: 55: 53$ & 23.9 & 634 & 1.88 & 7.27 & 4.7 & 55.6 & 1.8 \\
\hline & & $10: 15: 53$ & 23.9 & 634 & 1.88 & 7.28 & 4.8 & 57.0 & 1.9 \\
\hline & & $10: 20: 53$ & 24.0 & 634 & 1.89 & 7.29 & 4.8 & 57.5 & 1.8 \\
\hline & & $10: 25: 53$ & 24.0 & 634 & 1.88 & 7.29 & 4.9 & 58.5 & 1.7 \\
\hline & & $10: 30: 53$ & 23.9 & 634 & 1.89 & 7.30 & 5.0 & 59.5 & 1.9 \\
\hline & & $10: 35: 53$ & 23.9 & 634 & 1.89 & 7.31 & 5.1 & 60.2 & 1.8 \\
\hline & & $10: 40: 53$ & 24.0 & 634 & 1.89 & 7.31 & 5.1 & 60.5 & 1.7 \\
\hline & & $10: 45: 53$ & 24.1 & 634 & 1.89 & 7.31 & 5.1 & 60.8 & 1.8 \\
\hline & & $10: 50: 53$ & 24.0 & 634 & 1.89 & 7.31 & 5.2 & 61.9 & 1.7 \\
\hline & & $10: 55: 53$ & 24.1 & 634 & 1.89 & 7.31 & 5.2 & 61.8 & 1.7 \\
\hline & & 11:00:53 & 24.1 & 634 & 1.89 & 7.32 & 5.3 & 62.8 & 1.8 \\
\hline & & $11: 05: 53$ & 24.2 & 634 & 1.89 & 7.32 & 5.3 & 63.0 & 1.8 \\
\hline & & $11: 40: 53$ & 24.3 & 634 & 1.88 & 7.36 & 5.8 & 69.2 & 1.6 \\
\hline & & $11: 45: 53$ & 24.4 & 634 & 1.88 & 7.36 & 5.8 & 69.2 & 1.5 \\
\hline & & $11: 50: 53$ & 24.3 & 634 & 1.88 & 7.36 & 5.8 & 69.6 & 1.5 \\
\hline & & $11: 55: 53$ & 24.3 & 634 & 1.88 & 7.37 & 5.9 & 70.4 & 1.5 \\
\hline & & $12: 00: 53$ & 24.4 & 634 & 1.88 & 7.37 & 5.9 & 70.5 & 1.7 \\
\hline & & $12: 05: 53$ & 24.4 & 634 & 1.88 & 7.37 & 5.9 & 70.9 & 1.6 \\
\hline & & $12: 10: 53$ & 24.4 & 634 & 1.88 & 7.37 & 6.0 & 71.4 & 1.7 \\
\hline & & $12: 15: 53$ & 24.3 & 634 & 1.88 & 7.39 & 6.1 & 73.3 & 1.8 \\
\hline & & $12: 20: 53$ & 24.4 & 635 & 1.88 & 7.38 & 6.0 & 72.4 & 1.8 \\
\hline & & $12: 25: 53$ & 24.4 & 634 & 1.87 & 7.38 & 6.1 & 73.5 & 1.8 \\
\hline & & $12: 30: 53$ & 24.4 & 634 & 1.87 & 7.38 & 6.1 & 73.5 & 1.5 \\
\hline & & $12: 35: 53$ & 24.5 & 634 & 1.87 & 7.39 & 6.2 & 74.0 & 1.6 \\
\hline & & $12: 40: 53$ & 24.5 & 634 & 1.87 & 7.39 & 6.2 & 74.3 & 1.7 \\
\hline & & $12: 45: 53$ & 24.5 & 634 & 1.87 & 7.39 & 6.2 & 74.6 & 1.7 \\
\hline & & $12: 50: 53$ & 24.6 & 634 & 1.86 & 7.39 & 6.3 & 75.3 & 1.6 \\
\hline & & $12: 55: 53$ & 24.5 & 634 & 1.86 & 7.40 & 6.4 & 76.4 & 1.7 \\
\hline
\end{tabular}


Table 1-2. Chemical and physical properties measured by water-quality monitors during the period of dye tracing in Tacony/ Frankford Creek, Philadelphia, Pa. on August 18, September 1, and September 3, 2009.-Continued

$\left[{ }^{\circ} \mathrm{C}\right.$, degrees Celsius; $\mu \mathrm{S} / \mathrm{cm}$, microsiemens per centimter; mg/L, milligrams per liter; FNU, Formazin Nephelometric units; USGS, U.S. Geological Survey; ,-- no data]

\begin{tabular}{|c|c|c|c|c|c|c|c|c|c|}
\hline Site & Date & Time & $\begin{array}{c}\text { Temper- } \\
\text { ature } \\
\left({ }^{\circ} \mathrm{C}\right)\end{array}$ & $\begin{array}{c}\text { Specific } \\
\text { conduc- } \\
\text { tance } \\
(\mu \mathrm{S} / \mathrm{cm})\end{array}$ & $\begin{array}{c}\text { Sonde depth } \\
\text { or gage } \\
\text { height }^{1} \\
\text { (feet) }\end{array}$ & pH & $\begin{array}{l}\text { Dissolved } \\
\text { oxygen } \\
\text { (DO) } \\
\text { concen- } \\
\text { tration } \\
\text { (mg/L) } \\
\end{array}$ & $\begin{array}{c}\text { DO } \\
\text { saturation } \\
\text { (percent) }\end{array}$ & $\begin{array}{c}\text { Turbidity } \\
\text { (FNU) }\end{array}$ \\
\hline & & $13: 00: 53$ & 24.6 & 634 & 1.86 & 7.41 & 6.4 & 77.4 & 1.7 \\
\hline & & $13: 15: 53$ & 24.6 & 635 & 1.85 & 7.45 & 6.8 & 81.4 & 1.5 \\
\hline & & $13: 20: 53$ & 24.6 & 635 & 1.85 & 7.46 & 6.8 & 82.2 & 1.5 \\
\hline & & $13: 25: 53$ & 24.7 & 635 & 1.85 & 7.46 & 6.9 & 83.0 & 1.4 \\
\hline & & $13: 30: 53$ & 24.7 & 635 & 1.85 & 7.47 & 7.0 & 83.9 & 1.4 \\
\hline & & $13: 35: 53$ & 24.8 & 635 & 1.84 & 7.46 & 6.9 & 83.1 & 1.5 \\
\hline & & $13: 55: 53$ & 24.8 & 635 & 1.84 & 7.48 & 7.1 & 85.8 & 1.7 \\
\hline & & $14: 00: 53$ & 24.8 & 635 & 1.84 & 7.48 & 7.1 & 85.8 & 1.4 \\
\hline & & $14: 05: 53$ & 24.8 & 635 & 1.84 & 7.49 & 7.2 & 86.5 & 1.4 \\
\hline & & $14: 10: 53$ & 24.9 & 636 & 1.83 & 7.50 & 7.3 & 88.0 & 1.5 \\
\hline & & $14: 15: 53$ & 24.9 & 636 & 1.83 & 7.50 & 7.3 & 88.2 & 1.4 \\
\hline & & $14: 20: 53$ & 24.9 & 636 & 1.83 & 7.51 & 7.3 & 88.9 & 1.4 \\
\hline & & $14: 25: 53$ & 24.9 & 636 & 1.83 & 7.51 & 7.4 & 90.1 & 1.4 \\
\hline & & $14: 30: 53$ & 25.0 & 636 & 1.83 & 7.52 & 7.5 & 90.3 & 1.5 \\
\hline & & $14: 35: 53$ & 25.0 & 636 & 1.83 & 7.53 & 7.5 & 90.6 & 1.4 \\
\hline & & $14: 40: 53$ & 25.0 & 636 & 1.83 & 7.53 & 7.5 & 91.3 & 1.5 \\
\hline & & $14: 45: 53$ & 25.0 & 636 & 1.82 & 7.53 & 7.5 & 91.5 & 1.4 \\
\hline & & $15: 20: 53$ & 25.2 & 637 & 1.81 & 7.57 & 7.9 & 95.5 & 1.4 \\
\hline & & $15: 25: 53$ & 25.2 & 637 & 1.81 & 7.57 & 7.8 & 95.4 & 1.5 \\
\hline & & $15: 30: 53$ & 25.1 & 637 & 1.81 & 7.57 & 7.9 & 95.5 & 1.4 \\
\hline & & $15: 35: 53$ & 25.1 & 637 & 1.80 & 7.57 & 7.9 & 95.9 & 1.4 \\
\hline & & $15: 40: 53$ & 25.1 & 637 & 1.80 & 7.59 & 8.0 & 96.9 & 1.4 \\
\hline & & $15: 45: 53$ & 25.2 & 637 & 1.80 & 7.59 & 8.0 & 97.5 & 1.4 \\
\hline & & $15: 50: 53$ & 25.2 & 637 & 1.80 & 7.60 & 8.0 & 97.7 & 1.5 \\
\hline & & $15: 55: 53$ & 25.2 & 637 & 1.80 & 7.60 & 8.1 & 98.3 & 1.4 \\
\hline & & $16: 00: 53$ & 25.2 & 637 & 1.80 & 7.60 & 8.1 & 98.9 & 1.4 \\
\hline & & $16: 05: 53$ & 25.3 & 637 & 1.80 & 7.61 & 8.2 & 99.5 & 1.5 \\
\hline & & $16: 10: 53$ & 25.2 & 637 & 1.80 & 7.61 & 8.1 & 98.7 & 1.5 \\
\hline & & $16: 15: 53$ & 25.2 & 637 & 1.79 & 7.62 & 8.2 & 99.5 & 1.7 \\
\hline & & $16: 20: 53$ & 25.2 & 638 & 1.79 & 7.62 & 8.2 & 99.7 & 1.7 \\
\hline & & $16: 25: 53$ & 25.3 & 638 & 1.79 & 7.63 & 8.3 & 100.5 & 1.4 \\
\hline & & $16: 30: 53$ & 25.3 & 638 & 1.79 & 7.63 & 8.3 & 100.7 & 1.4 \\
\hline & & $16: 35: 53$ & 25.3 & 638 & 1.79 & 7.63 & 8.3 & 101.1 & 1.5 \\
\hline
\end{tabular}


Table 1-2. Chemical and physical properties measured by water-quality monitors during the period of dye tracing in Tacony/ Frankford Creek, Philadelphia, Pa. on August 18, September 1, and September 3, 2009.-Continued

$\left[{ }^{\circ} \mathrm{C}\right.$, degrees Celsius; $\mu \mathrm{S} / \mathrm{cm}$, microsiemens per centimter; mg/L, milligrams per liter; FNU, Formazin Nephelometric units; USGS, U.S. Geological Survey; ,-- no data]

\begin{tabular}{|c|c|c|c|c|c|c|c|c|c|}
\hline Site & Date & Time & $\begin{array}{c}\text { Temper- } \\
\text { ature } \\
\left({ }^{\circ} \mathrm{C}\right)\end{array}$ & $\begin{array}{c}\text { Specific } \\
\text { conduc- } \\
\text { tance } \\
(\mu \mathrm{S} / \mathrm{cm})\end{array}$ & $\begin{array}{c}\text { Sonde depth } \\
\text { or gage } \\
\text { height }^{1} \\
\text { (feet) }\end{array}$ & pH & $\begin{array}{c}\text { Dissolved } \\
\text { oxygen } \\
\text { (DO) } \\
\text { concen- } \\
\text { tration } \\
\text { (mg/L) }\end{array}$ & $\begin{array}{c}\text { DO } \\
\text { saturation } \\
\text { (percent) }\end{array}$ & $\begin{array}{c}\text { Turbidity } \\
\text { (FNU) }\end{array}$ \\
\hline & & $16: 40: 53$ & 25.3 & 638 & 1.79 & 7.63 & 8.3 & 101.0 & 1.4 \\
\hline & & $16: 45: 53$ & 25.3 & 638 & 1.79 & 7.63 & 8.3 & 101.0 & 1.4 \\
\hline & & $16: 55: 53$ & 25.3 & 638 & 1.79 & 7.63 & 8.3 & 100.9 & 1.5 \\
\hline & & $17: 00: 53$ & 25.3 & 638 & 1.79 & 7.63 & 8.3 & 101.0 & 1.7 \\
\hline & & $17: 05: 53$ & 25.3 & 638 & 1.79 & 7.63 & 8.3 & 100.9 & 1.5 \\
\hline & & $17: 10: 53$ & 25.3 & 638 & 1.78 & 7.64 & 8.3 & 101.0 & 1.8 \\
\hline & & $17: 15: 53$ & 25.3 & 638 & 1.78 & 7.64 & 8.3 & 101.3 & 1.3 \\
\hline & & $17: 40: 53$ & 25.3 & 638 & 1.77 & 7.65 & 8.3 & 101.8 & 1.8 \\
\hline & & $17: 45: 53$ & 25.3 & 638 & 1.77 & 7.65 & 8.4 & 101.8 & 1.6 \\
\hline & & $17: 50: 53$ & 25.4 & 638 & 1.77 & 7.65 & 8.4 & 101.8 & 1.5 \\
\hline & & $17: 55: 53$ & 25.4 & 638 & 1.78 & 7.65 & 8.4 & 101.8 & 1.6 \\
\hline & & $18: 00: 53$ & 25.4 & 638 & 1.78 & 7.66 & 8.4 & 101.9 & 1.6 \\
\hline & & $18: 05: 53$ & 25.4 & 638 & 1.78 & 7.66 & 8.4 & 102.5 & 1.4 \\
\hline & & $18: 10: 53$ & 25.4 & 638 & 1.78 & 7.67 & 8.4 & 102.4 & 1.4 \\
\hline & & $18: 15: 53$ & 25.4 & 638 & 1.78 & 7.67 & 8.4 & 102.7 & 1.4 \\
\hline & & $18: 20: 53$ & 25.4 & 639 & 1.77 & 7.67 & 8.4 & 102.3 & 1.5 \\
\hline & & $18: 25: 53$ & 25.4 & 639 & 1.77 & 7.67 & 8.4 & 102.2 & 1.5 \\
\hline & & 19:00:53 & 25.4 & 639 & 1.78 & 7.66 & 8.3 & 101.6 & 1.7 \\
\hline & & $19: 05: 53$ & 25.4 & 639 & 1.78 & 7.66 & 8.3 & 101.3 & 1.6 \\
\hline & & $19: 10: 53$ & 25.4 & 639 & 1.78 & 7.66 & 8.3 & 101.2 & 1.8 \\
\hline & & $19: 15: 53$ & 25.4 & 639 & 1.78 & 7.66 & 8.3 & 100.9 & 1.7 \\
\hline & & $19: 20: 53$ & 25.4 & 639 & 1.78 & 7.65 & 8.2 & 100.2 & 1.5 \\
\hline & & $19: 25: 53$ & 25.4 & 639 & 1.78 & 7.65 & 8.2 & 100.3 & 1.6 \\
\hline & & $19: 30: 53$ & 25.4 & 639 & 1.78 & 7.65 & 8.2 & 99.7 & 1.6 \\
\hline & & $19: 35: 53$ & 25.4 & 640 & 1.78 & 7.64 & 8.1 & 99.0 & 1.5 \\
\hline & & $19: 40: 53$ & 25.4 & 640 & 1.78 & 7.63 & 8.1 & 98.7 & 1.6 \\
\hline & & $19: 45: 53$ & 25.4 & 639 & 1.79 & 7.64 & 8.1 & 98.4 & 1.8 \\
\hline & & $19: 50: 53$ & 25.4 & 639 & 1.80 & 7.64 & 8.0 & 97.8 & 1.5 \\
\hline & & $19: 55: 53$ & 25.4 & 639 & 1.83 & 7.63 & 8.0 & 97.7 & 1.5 \\
\hline & & $20: 00: 53$ & 25.3 & 640 & 1.84 & 7.63 & 8.0 & 97.3 & 2.9 \\
\hline & & $20: 05: 53$ & 25.3 & 639 & 1.84 & 7.62 & 7.9 & 96.6 & 2.5 \\
\hline
\end{tabular}


Table 1-2. Chemical and physical properties measured by water-quality monitors during the period of dye tracing in Tacony/ Frankford Creek, Philadelphia, Pa. on August 18, September 1, and September 3, 2009.-Continued

$\left[{ }^{\circ} \mathrm{C}\right.$, degrees Celsius; $\mu \mathrm{S} / \mathrm{cm}$, microsiemens per centimter; mg/L, milligrams per liter; FNU, Formazin Nephelometric units; USGS, U.S. Geological Survey; ,-- no data]

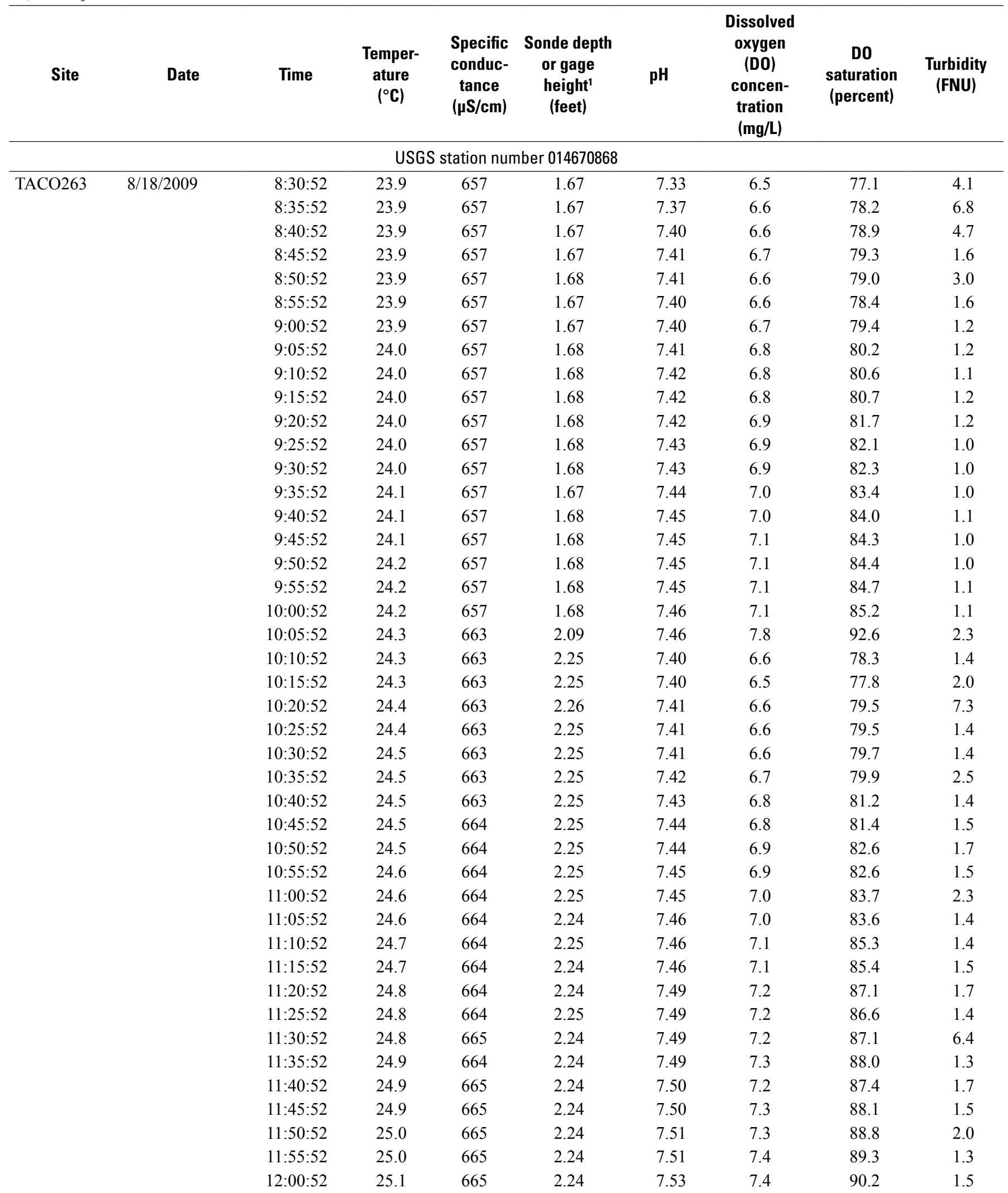


Table 1-2. Chemical and physical properties measured by water-quality monitors during the period of dye tracing in Tacony/ Frankford Creek, Philadelphia, Pa. on August 18, September 1, and September 3, 2009.-Continued

$\left[{ }^{\circ} \mathrm{C}\right.$, degrees Celsius; $\mu \mathrm{S} / \mathrm{cm}$, microsiemens per centimter; mg/L, milligrams per liter; FNU, Formazin Nephelometric units; USGS, U.S. Geological Survey; ,-- no data]

\begin{tabular}{|c|c|c|c|c|c|c|c|c|c|}
\hline Site & Date & Time & $\begin{array}{c}\text { Temper- } \\
\text { ature } \\
\left({ }^{\circ} \mathrm{C}\right)\end{array}$ & $\begin{array}{c}\text { Specific } \\
\text { conduc- } \\
\text { tance } \\
(\mu \mathrm{S} / \mathrm{cm})\end{array}$ & $\begin{array}{c}\text { Sonde depth } \\
\text { or gage } \\
\text { height }^{1} \\
\text { (feet) }\end{array}$ & $\mathrm{pH}$ & $\begin{array}{l}\text { Dissolved } \\
\text { oxygen } \\
\text { (DO) } \\
\text { concen- } \\
\text { tration } \\
\text { (mg/L) }\end{array}$ & $\begin{array}{c}\text { DO } \\
\text { saturation } \\
\text { (percent) }\end{array}$ & $\begin{array}{c}\text { Turbidity } \\
\text { (FNU) }\end{array}$ \\
\hline & & $12: 05: 52$ & 25.1 & 665 & 2.23 & 7.52 & 7.4 & 90.1 & 1.4 \\
\hline & & $12: 20: 52$ & 25.2 & 665 & 2.23 & 7.54 & 7.5 & 91.7 & 1.4 \\
\hline & & $12: 25: 52$ & 25.2 & 665 & 2.23 & 7.53 & 7.5 & 91.3 & 1.3 \\
\hline & & $12: 30: 52$ & 25.2 & 665 & 2.23 & 7.54 & 7.5 & 91.7 & 1.3 \\
\hline & & $12: 35: 52$ & 25.2 & 665 & 2.22 & 7.54 & 7.6 & 92.0 & 1.4 \\
\hline & & $12: 40: 52$ & 25.2 & 665 & 2.22 & 7.54 & 7.6 & 92.9 & 1.3 \\
\hline & & $13: 00: 52$ & 25.4 & 666 & 2.21 & 7.57 & 7.8 & 94.7 & 1.5 \\
\hline & & $13: 05: 52$ & 25.4 & 665 & 2.21 & 7.57 & 7.8 & 95.3 & 1.5 \\
\hline & & $13: 10: 52$ & 25.4 & 665 & 2.21 & 7.58 & 7.8 & 95.2 & 1.4 \\
\hline & & $13: 15: 52$ & 25.4 & 666 & 2.21 & 7.58 & 7.9 & 95.9 & 1.3 \\
\hline & & $13: 20: 52$ & 25.5 & 666 & 2.20 & 7.60 & 7.9 & 96.9 & 1.3 \\
\hline & & $13: 25: 52$ & 25.5 & 666 & 2.20 & 7.60 & 8.0 & 97.7 & 1.3 \\
\hline & & $13: 30: 52$ & 25.5 & 666 & 2.20 & 7.61 & 8.0 & 98.0 & 1.4 \\
\hline & & $13: 35: 52$ & 25.4 & 666 & 2.20 & 7.60 & 7.9 & 96.9 & 1.4 \\
\hline & & $13: 40: 52$ & 25.4 & 666 & 2.19 & 7.59 & 7.9 & 95.8 & 1.6 \\
\hline & & $13: 45: 52$ & 25.5 & 665 & 2.19 & 7.60 & 8.1 & 98.4 & 1.2 \\
\hline & & $13: 50: 52$ & 25.5 & 666 & 2.19 & 7.60 & 8.0 & 98.0 & 1.3 \\
\hline & & $14: 25: 52$ & 25.5 & 666 & 2.18 & 7.62 & 8.3 & 101.2 & 1.1 \\
\hline & & $14: 30: 52$ & 25.5 & 666 & 2.17 & 7.63 & 8.2 & 100.6 & 1.5 \\
\hline & & $14: 35: 52$ & 25.6 & 666 & 2.18 & 7.64 & 8.4 & 102.5 & 1.0 \\
\hline & & $14: 40: 52$ & 25.6 & 667 & 2.18 & 7.66 & 8.4 & 102.7 & 1.0 \\
\hline & & $14: 45: 52$ & 25.6 & 667 & 2.18 & 7.67 & 8.3 & 101.9 & 1.1 \\
\hline & & $14: 50: 52$ & 25.5 & 667 & 2.17 & 7.65 & 8.2 & 100.5 & 1.4 \\
\hline & & $14: 55: 52$ & 25.6 & 667 & 2.17 & 7.65 & 8.3 & 102.1 & 1.4 \\
\hline & & $15: 00: 52$ & 25.6 & 667 & 2.17 & 7.66 & 8.3 & 101.5 & 1.2 \\
\hline & & $15: 05: 52$ & 25.5 & 667 & 2.16 & 7.65 & 8.2 & 100.4 & 1.1 \\
\hline & & $15: 10: 52$ & 25.5 & 667 & 2.17 & 7.65 & 8.2 & 100.3 & 3.4 \\
\hline & & $15: 15: 52$ & 25.5 & 667 & 2.17 & 7.62 & 8.1 & 99.4 & 1.9 \\
\hline & & $15: 20: 52$ & 25.6 & 667 & 2.17 & 7.64 & 8.3 & 102.0 & 1.4 \\
\hline & & $15: 25: 52$ & 25.6 & 667 & 2.16 & 7.67 & 8.4 & 102.7 & 1.4 \\
\hline & & $15: 30: 52$ & 25.6 & 667 & 2.16 & 7.69 & 8.4 & 103.3 & 1.4 \\
\hline & & $15: 35: 52$ & 25.5 & 668 & 2.16 & 7.66 & 8.2 & 100.8 & 1.4 \\
\hline & & $15: 40: 52$ & 25.5 & 668 & 2.15 & 7.65 & 8.2 & 100.5 & 1.2 \\
\hline
\end{tabular}


Table 1-2. Chemical and physical properties measured by water-quality monitors during the period of dye tracing in Tacony/ Frankford Creek, Philadelphia, Pa. on August 18, September 1, and September 3, 2009.-Continued

$\left[{ }^{\circ} \mathrm{C}\right.$, degrees Celsius; $\mu \mathrm{S} / \mathrm{cm}$, microsiemens per centimter; mg/L, milligrams per liter; FNU, Formazin Nephelometric units; USGS, U.S. Geological Survey; ,-- no data]

\begin{tabular}{|c|c|c|c|c|c|c|c|c|c|}
\hline Site & Date & Time & $\begin{array}{c}\text { Temper- } \\
\text { ature } \\
\left({ }^{\circ} \mathrm{C}\right)\end{array}$ & $\begin{array}{c}\text { Specific } \\
\text { conduc- } \\
\text { tance } \\
(\mu \mathrm{S} / \mathrm{cm})\end{array}$ & $\begin{array}{c}\text { Sonde depth } \\
\text { or gage } \\
\text { height }^{1} \\
\text { (feet) }\end{array}$ & $\mathbf{p H}$ & $\begin{array}{l}\text { Dissolved } \\
\text { oxygen } \\
\text { (DO) } \\
\text { concen- } \\
\text { tration } \\
\text { (mg/L) }\end{array}$ & $\begin{array}{c}\text { DO } \\
\text { saturation } \\
\text { (percent) }\end{array}$ & $\begin{array}{c}\text { Turbidity } \\
\text { (FNU) }\end{array}$ \\
\hline & & $15: 45: 52$ & 25.6 & 667 & 2.15 & 7.68 & 8.4 & 103.2 & 1.2 \\
\hline & & $15: 50: 52$ & 25.6 & 667 & 2.15 & 7.69 & 8.5 & 103.8 & 1.2 \\
\hline & & $15: 55: 52$ & 25.7 & 668 & 2.15 & 7.70 & 8.5 & 104.6 & 1.2 \\
\hline & & $16: 00: 52$ & 25.7 & 668 & 2.15 & 7.72 & 8.6 & 105.5 & 1.2 \\
\hline & & $16: 05: 52$ & 25.7 & 668 & 2.15 & 7.72 & 8.6 & 106.1 & 1.4 \\
\hline & & $16: 10: 52$ & 25.7 & 668 & 2.15 & 7.70 & 8.5 & 103.7 & 1.2 \\
\hline & & $16: 15: 52$ & 25.7 & 668 & 2.15 & 7.70 & 8.4 & 103.3 & 1.2 \\
\hline & & $16: 20: 52$ & 25.6 & 668 & 2.14 & 7.69 & 8.4 & 102.7 & 1.1 \\
\hline & & $16: 25: 52$ & 25.6 & 668 & 2.14 & 7.69 & 8.4 & 102.3 & 1.2 \\
\hline & & $16: 30: 52$ & 25.6 & 668 & 2.14 & 7.71 & 8.5 & 104.6 & 1.3 \\
\hline & & $16: 35: 52$ & 25.6 & 668 & 2.14 & 7.71 & 8.5 & 104.0 & 1.0 \\
\hline & & $16: 40: 52$ & 25.7 & 668 & 2.14 & 7.71 & 8.5 & 104.7 & 1.3 \\
\hline & & $16: 45: 52$ & 25.6 & 668 & 2.14 & 7.72 & 8.5 & 103.7 & 1.2 \\
\hline & & $16: 50: 52$ & 25.6 & 668 & 2.14 & 7.70 & 8.3 & 102.2 & 1.1 \\
\hline & & $16: 55: 52$ & 25.5 & 669 & 2.14 & 7.67 & 8.2 & 100.6 & 1.1 \\
\hline & & $17: 00: 52$ & 25.5 & 669 & 2.13 & 7.66 & 8.2 & 99.8 & 1.2 \\
\hline & & $17: 05: 52$ & 25.5 & 669 & 2.14 & 7.65 & 8.1 & 98.5 & 1.6 \\
\hline & & $17: 10: 52$ & 25.4 & 669 & 2.13 & 7.63 & 8.0 & 98.1 & 1.0 \\
\hline & & $17: 15: 52$ & 25.4 & 669 & 2.13 & 7.64 & 8.1 & 98.3 & 1.4 \\
\hline & & $17: 20: 52$ & 25.4 & 669 & 2.12 & 7.64 & 8.1 & 98.8 & 1.5 \\
\hline & & $17: 25: 52$ & 25.4 & 669 & 2.13 & 7.63 & 8.1 & 98.3 & 1.1 \\
\hline & & $17: 30: 52$ & 25.4 & 669 & 2.13 & 7.64 & 8.1 & 98.5 & 1.3 \\
\hline & & $17: 35: 52$ & 25.4 & 669 & 2.13 & 7.63 & 8.1 & 98.3 & 1.2 \\
\hline & & $17: 40: 52$ & 25.4 & 669 & 2.13 & 7.62 & 8.1 & 98.5 & 1.2 \\
\hline & & $17: 45: 52$ & 25.4 & 669 & 2.13 & 7.63 & 8.1 & 98.7 & 1.2 \\
\hline & & $17: 50: 52$ & 25.4 & 670 & 2.13 & 7.62 & 8.0 & 98.0 & 1.1 \\
\hline & & $17: 55: 52$ & 25.4 & 670 & 2.13 & 7.62 & 8.0 & 98.0 & 1.4 \\
\hline & & 18:00:52 & 25.4 & 670 & 2.13 & 7.61 & 8.0 & 97.6 & 1.4 \\
\hline & & $18: 05: 52$ & 25.4 & 670 & 2.13 & 7.60 & 8.0 & 97.3 & 1.1 \\
\hline & & $18: 10: 52$ & 25.4 & 670 & 2.13 & 7.61 & 8.0 & 97.3 & 1.2 \\
\hline & & $18: 15: 52$ & 25.4 & 670 & 2.13 & 7.59 & 8.0 & 97.1 & 1.0 \\
\hline & & $18: 20: 52$ & 25.4 & 670 & 2.13 & 7.58 & 7.9 & 96.7 & 1.7 \\
\hline & & $18: 25: 52$ & 25.4 & 670 & 2.13 & 7.58 & 7.9 & 96.1 & 1.0 \\
\hline & & $18: 30: 52$ & 25.4 & 670 & 2.13 & 7.59 & 7.9 & 95.9 & 1.2 \\
\hline & & $18: 35: 52$ & 25.4 & 670 & 2.13 & 7.58 & 7.8 & 95.4 & 1.0 \\
\hline & & $18: 40: 52$ & 25.3 & 670 & 2.13 & 7.59 & 7.8 & 95.0 & 1.0 \\
\hline & & $18: 45: 52$ & 25.3 & 670 & 2.13 & 7.60 & 7.8 & 94.6 & 1.5 \\
\hline & & $18: 50: 52$ & 25.4 & 670 & 2.13 & 7.58 & 7.8 & 94.7 & 1.2 \\
\hline & & $18: 55: 52$ & 25.4 & 670 & 2.13 & 7.58 & 7.8 & 94.8 & 1.1 \\
\hline & & $19: 00: 52$ & 25.4 & 670 & 2.13 & 7.58 & 7.8 & 94.6 & 1.3 \\
\hline & & $19: 05: 52$ & 25.4 & 671 & 2.14 & 7.57 & 7.7 & 94.2 & 1.2 \\
\hline & & $19: 10: 52$ & 25.4 & 671 & 2.14 & 7.56 & 7.7 & 94.2 & 1.4 \\
\hline & & $19: 15: 52$ & 25.3 & 671 & 2.14 & 7.56 & 7.7 & 93.4 & 1.4 \\
\hline & & $19: 20: 52$ & 25.4 & 671 & 2.13 & 7.55 & 7.6 & 93.3 & 1.2 \\
\hline
\end{tabular}


Table 1-2. Chemical and physical properties measured by water-quality monitors during the period of dye tracing in Tacony/ Frankford Creek, Philadelphia, Pa. on August 18, September 1, and September 3, 2009.-Continued

$\left[{ }^{\circ} \mathrm{C}\right.$, degrees Celsius; $\mu \mathrm{S} / \mathrm{cm}$, microsiemens per centimter; mg/L, milligrams per liter; FNU, Formazin Nephelometric units; USGS, U.S. Geological Survey; --, no data]

\begin{tabular}{|c|c|c|c|c|c|c|c|c|c|}
\hline Site & Date & Time & $\begin{array}{c}\text { Temper- } \\
\text { ature } \\
\left({ }^{\circ} \mathrm{C}\right)\end{array}$ & $\begin{array}{c}\text { Specific } \\
\text { conduc- } \\
\text { tance } \\
(\mu \mathrm{S} / \mathrm{cm})\end{array}$ & $\begin{array}{l}\text { Sonde depth } \\
\text { or gage } \\
\text { height }^{1} \\
\text { (feet) }\end{array}$ & pH & $\begin{array}{c}\text { Dissolved } \\
\text { oxygen } \\
\text { (DO) } \\
\text { concen- } \\
\text { tration } \\
\text { (mg/L) }\end{array}$ & $\begin{array}{c}\text { DO } \\
\text { saturation } \\
\text { (percent) }\end{array}$ & $\begin{array}{c}\text { Turbidity } \\
\text { (FNU) }\end{array}$ \\
\hline & & $19: 25: 52$ & 25.3 & 671 & 2.14 & 7.55 & 7.6 & 92.7 & 1.3 \\
\hline & & $19: 40: 52$ & 25.3 & 671 & 2.14 & 7.54 & 7.5 & 91.6 & 1.1 \\
\hline & & $19: 45: 52$ & 25.3 & 671 & 2.15 & 7.53 & 7.5 & 91.3 & 1.4 \\
\hline & & $19: 50: 52$ & 25.3 & 671 & 2.16 & 7.52 & 7.5 & 91.0 & 1.3 \\
\hline & & $19: 55: 52$ & 25.3 & 671 & 2.17 & 7.52 & 7.4 & 90.6 & 1.3 \\
\hline \multicolumn{10}{|c|}{ USGS station number 014670869} \\
\hline \multirow{26}{*}{ TACO260 } & & $8: 45: 59$ & 24.2 & 647 & 1.51 & 7.38 & 6.7 & 79.9 & 3.1 \\
\hline & & $8: 50: 59$ & 24.2 & 647 & 1.41 & 7.38 & 6.7 & 79.9 & 3.1 \\
\hline & & $8: 55: 59$ & 24.2 & 648 & 1.40 & 7.38 & 6.7 & 80.5 & 2.6 \\
\hline & & $9: 00: 59$ & 24.2 & 648 & 1.43 & 7.38 & 6.7 & 80.1 & 2.2 \\
\hline & & 9:05:59 & 24.2 & 647 & 1.38 & 7.38 & 6.8 & 80.7 & 2.5 \\
\hline & & $9: 10: 59$ & 24.2 & 637 & 1.43 & 7.39 & 6.8 & 80.7 & 2.4 \\
\hline & & $9: 15: 59$ & 24.2 & 650 & 1.49 & 7.38 & 6.8 & 80.6 & 2.3 \\
\hline & & $9: 20: 59$ & 24.3 & 651 & 1.44 & 7.38 & 6.7 & 80.6 & 2.4 \\
\hline & & $9: 25: 59$ & 24.3 & 623 & 1.44 & 7.38 & 6.7 & 80.3 & 2.5 \\
\hline & & $9: 30: 59$ & 24.3 & 651 & 1.50 & 7.38 & 6.8 & 80.8 & 2.3 \\
\hline & & $10: 10: 59$ & 24.4 & 649 & 1.47 & 7.39 & 6.9 & 82.1 & 2.1 \\
\hline & & $10: 15: 59$ & 24.4 & 649 & 1.41 & 7.39 & 6.9 & 82.3 & 2.0 \\
\hline & & $10: 20: 59$ & 24.5 & 637 & 1.41 & 7.40 & 6.9 & 82.9 & 2.1 \\
\hline & & $10: 25: 59$ & 24.4 & 648 & 1.41 & 7.39 & 6.9 & 82.3 & 2.0 \\
\hline & & $10: 31: 04$ & 24.5 & 647 & 1.50 & 7.40 & 7.0 & 83.4 & 4.0 \\
\hline & & $10: 35: 59$ & 24.6 & 647 & 1.48 & 7.40 & 6.9 & 83.3 & 2.6 \\
\hline & & $10: 40: 59$ & 24.7 & 649 & 1.45 & 7.42 & 7.0 & 84.0 & 1.9 \\
\hline & & $10: 45: 59$ & 24.6 & 647 & 1.44 & 7.40 & 6.9 & 83.1 & 1.9 \\
\hline & & $10: 50: 59$ & 24.6 & 647 & 1.34 & 7.40 & 7.0 & 83.7 & 2.1 \\
\hline & & $10: 55: 59$ & 24.7 & 651 & 1.49 & 7.42 & 7.0 & 84.4 & 1.9 \\
\hline & & 11:00:59 & 24.7 & 650 & 1.49 & 7.41 & 7.0 & 84.2 & 2.3 \\
\hline & & $11: 05: 59$ & 24.8 & 647 & 1.42 & 7.42 & 7.0 & 84.9 & 1.8 \\
\hline & & $11: 10: 59$ & 24.8 & 646 & 1.46 & 7.41 & 7.0 & 84.0 & 2.0 \\
\hline & & $11: 15: 59$ & 24.8 & 650 & 1.49 & 7.42 & 7.1 & 85.2 & 3.1 \\
\hline & & $11: 20: 59$ & 24.8 & 650 & 1.43 & 7.41 & 7.0 & 84.3 & 2.5 \\
\hline & & $11: 25: 59$ & 24.9 & 649 & 1.38 & 7.42 & 7.0 & 84.8 & 2.0 \\
\hline
\end{tabular}


Table 1-2. Chemical and physical properties measured by water-quality monitors during the period of dye tracing in Tacony/ Frankford Creek, Philadelphia, Pa. on August 18, September 1, and September 3, 2009.-Continued

$\left[{ }^{\circ} \mathrm{C}\right.$, degrees Celsius; $\mu \mathrm{S} / \mathrm{cm}$, microsiemens per centimter; mg/L, milligrams per liter; FNU, Formazin Nephelometric units; USGS, U.S. Geological Survey; ,-- no data]

\begin{tabular}{|c|c|c|c|c|c|c|c|c|c|}
\hline Site & Date & Time & $\begin{array}{c}\text { Temper- } \\
\text { ature } \\
\left({ }^{\circ} \mathrm{C}\right)\end{array}$ & $\begin{array}{c}\text { Specific } \\
\text { conduc- } \\
\text { tance } \\
(\mu \mathrm{S} / \mathrm{cm})\end{array}$ & $\begin{array}{c}\text { Sonde depth } \\
\text { or gage } \\
\text { height }^{1} \\
\text { (feet) }\end{array}$ & pH & $\begin{array}{l}\text { Dissolved } \\
\text { oxygen } \\
\text { (DO) } \\
\text { concen- } \\
\text { tration } \\
\text { (mg/L) }\end{array}$ & $\begin{array}{c}\text { DO } \\
\text { saturation } \\
\text { (percent) }\end{array}$ & $\begin{array}{c}\text { Turbidity } \\
\text { (FNU) }\end{array}$ \\
\hline & & $11: 30: 59$ & 24.9 & 605 & 1.37 & 7.42 & 7.0 & 85.1 & 2.9 \\
\hline & & $11: 45: 59$ & 25.0 & 650 & 1.33 & 7.43 & 7.1 & 85.6 & 1.7 \\
\hline & & $11: 50: 59$ & 25.0 & 648 & 1.44 & 7.44 & 7.1 & 86.5 & 2.7 \\
\hline & & $11: 55: 59$ & 25.0 & 644 & 1.42 & 7.44 & 7.2 & 87.0 & 2.2 \\
\hline & & $12: 00: 59$ & 25.1 & 639 & 1.41 & 7.45 & 7.2 & 87.0 & 2.6 \\
\hline & & $12: 05: 59$ & 25.2 & 647 & 1.42 & 7.45 & 7.2 & 87.7 & 2.0 \\
\hline & & $12: 25: 59$ & 25.4 & 592 & 1.46 & 7.47 & 7.3 & 89.2 & 2.4 \\
\hline & & $12: 30: 59$ & 25.3 & 645 & 1.37 & 7.47 & 7.3 & 88.7 & 2.3 \\
\hline & & $12: 35: 59$ & 25.4 & 649 & 1.40 & 7.49 & 7.3 & 89.7 & 2.0 \\
\hline & & $12: 40: 59$ & 25.5 & 627 & 1.45 & 7.49 & 7.4 & 90.4 & 2.3 \\
\hline & & $12: 45: 59$ & 25.6 & 652 & 1.43 & 7.50 & 7.4 & 90.6 & 2.1 \\
\hline & & $12: 50: 59$ & 25.6 & 651 & 1.43 & 7.51 & 7.4 & 91.2 & 2.0 \\
\hline & & $12: 55: 59$ & 25.5 & 649 & 1.34 & 7.50 & 7.4 & 90.4 & 2.0 \\
\hline & & 13:00:59 & 25.5 & 650 & 1.45 & 7.52 & 7.5 & 92.0 & 2.3 \\
\hline & & $13: 05: 59$ & 25.4 & 641 & 1.41 & 7.51 & 7.4 & 90.8 & 2.1 \\
\hline & & $13: 10: 59$ & 25.5 & 651 & 1.44 & 7.53 & 7.6 & 92.7 & 2.1 \\
\hline & & $13: 15: 59$ & 25.5 & 647 & 1.40 & 7.53 & 7.6 & 92.5 & 1.8 \\
\hline & & $13: 50: 59$ & 25.8 & 650 & 1.37 & 7.56 & 7.7 & 94.0 & 1.7 \\
\hline & & $13: 55: 59$ & 25.8 & 637 & 1.37 & 7.56 & 7.7 & 94.4 & 2.0 \\
\hline & & 14:00:59 & 25.7 & 650 & 1.38 & 7.55 & 7.6 & 93.1 & 2.2 \\
\hline & & $14: 05: 59$ & 25.7 & 651 & 1.40 & 7.56 & 7.7 & 94.5 & 1.7 \\
\hline & & $14: 10: 59$ & 25.8 & 620 & 1.35 & 7.58 & 7.8 & 95.6 & 1.9 \\
\hline & & $14: 15: 59$ & 25.7 & 610 & 1.42 & 7.56 & 7.7 & 94.2 & 2.0 \\
\hline & & $14: 20: 59$ & 25.7 & 651 & 1.36 & 7.58 & 7.8 & 95.7 & 2.2 \\
\hline & & $14: 25: 59$ & 25.8 & 651 & 1.32 & 7.58 & 7.8 & 95.9 & 1.6 \\
\hline & & $14: 30: 59$ & 25.8 & 650 & 1.38 & 7.59 & 7.9 & 96.7 & 2.5 \\
\hline & & $14: 35: 59$ & 25.9 & 644 & 1.25 & 7.59 & 7.9 & 96.7 & 1.6 \\
\hline & & $14: 40: 59$ & 26.1 & 649 & 1.38 & 7.63 & 8.0 & 98.4 & 2.1 \\
\hline & & $14: 45: 59$ & 26.0 & 615 & 1.34 & 7.60 & 7.8 & 95.6 & 2.0 \\
\hline & & $14: 50: 59$ & 26.0 & 652 & 1.31 & 7.61 & 7.9 & 97.1 & 3.2 \\
\hline & & $14: 55: 59$ & 26.0 & 651 & 1.40 & 7.61 & 7.9 & 97.5 & 1.8 \\
\hline & & $15: 00: 59$ & 26.0 & 650 & 1.38 & 7.62 & 7.9 & 98.0 & 2.5 \\
\hline & & $15: 05: 59$ & 26.0 & 622 & 1.31 & 7.63 & 7.9 & 97.9 & 2.1 \\
\hline
\end{tabular}


Table 1-2. Chemical and physical properties measured by water-quality monitors during the period of dye tracing in Tacony/ Frankford Creek, Philadelphia, Pa. on August 18, September 1, and September 3, 2009.-Continued

$\left[{ }^{\circ} \mathrm{C}\right.$, degrees Celsius; $\mu \mathrm{S} / \mathrm{cm}$, microsiemens per centimter; mg/L, milligrams per liter; FNU, Formazin Nephelometric units; USGS, U.S. Geological Survey; --, no data]

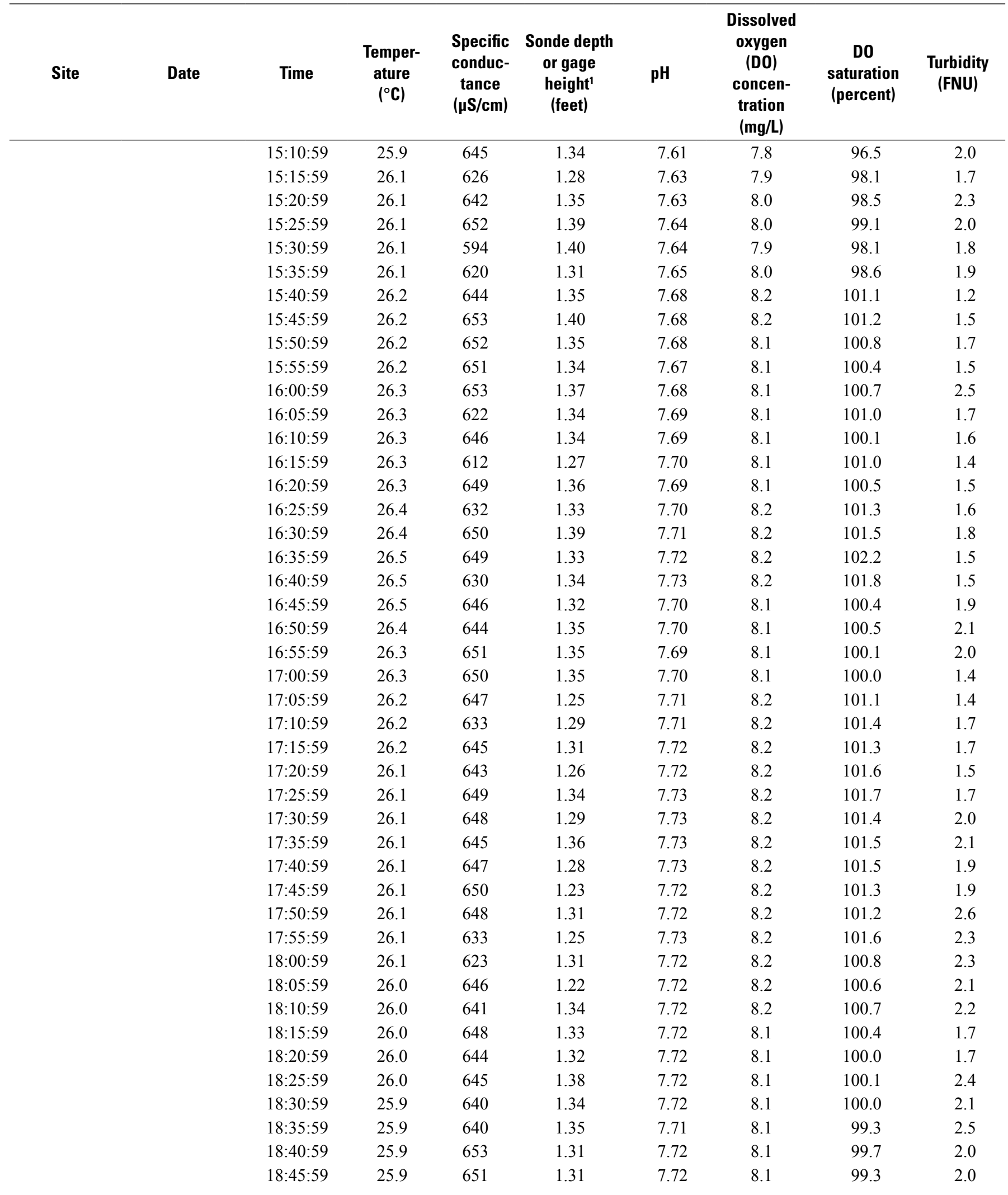


Table 1-2. Chemical and physical properties measured by water-quality monitors during the period of dye tracing in Tacony/ Frankford Creek, Philadelphia, Pa. on August 18, September 1, and September 3, 2009.-Continued

$\left[{ }^{\circ} \mathrm{C}\right.$, degrees Celsius; $\mu \mathrm{S} / \mathrm{cm}$, microsiemens per centimter; mg/L, milligrams per liter; FNU, Formazin Nephelometric units; USGS, U.S. Geological Survey; ,-- no data]

\begin{tabular}{|c|c|c|c|c|c|c|c|c|c|}
\hline Site & Date & Time & $\begin{array}{l}\text { Temper- } \\
\text { ature } \\
\left({ }^{\circ} \mathrm{C}\right)\end{array}$ & $\begin{array}{c}\text { Specific } \\
\text { conduc- } \\
\text { tance } \\
(\mu \mathrm{S} / \mathrm{cm})\end{array}$ & $\begin{array}{c}\text { Sonde depth } \\
\text { or gage } \\
\text { height }^{1} \\
\text { (feet) }\end{array}$ & pH & $\begin{array}{l}\text { Dissolved } \\
\text { oxygen } \\
\text { (DO) } \\
\text { concen- } \\
\text { tration } \\
\text { (mg/L) }\end{array}$ & $\begin{array}{c}\text { DO } \\
\text { saturation } \\
\text { (percent) }\end{array}$ & $\begin{array}{c}\text { Turbidity } \\
\text { (FNU) }\end{array}$ \\
\hline & & 18:50:59 & 25.9 & 647 & 1.30 & 7.71 & 8.1 & 99.7 & 1.7 \\
\hline & & $19: 05: 59$ & 25.9 & 647 & 1.30 & 7.71 & 8.0 & 99.0 & 1.7 \\
\hline & & 19:10:59 & 25.9 & 651 & 1.33 & 7.70 & 8.0 & 98.8 & 2.0 \\
\hline & & $19: 15: 59$ & 25.8 & 649 & 1.32 & 7.71 & 8.0 & 98.9 & 2.0 \\
\hline & & $19: 20: 59$ & 25.8 & 650 & 1.36 & 7.71 & 8.0 & 98.4 & 1.9 \\
\hline & & $19: 25: 59$ & 25.8 & 651 & 1.29 & 7.71 & 8.0 & 98.4 & 1.5 \\
\hline & & $19: 45: 59$ & 25.7 & 629 & 1.34 & 7.70 & 8.0 & 97.6 & 1.7 \\
\hline & & $19: 50: 59$ & 25.7 & 648 & 1.32 & 7.71 & 8.0 & 98.2 & 1.7 \\
\hline & & $19: 55: 59$ & 25.7 & 629 & 1.39 & 7.70 & 8.0 & 97.6 & 1.4 \\
\hline \multicolumn{10}{|c|}{ USGS station number 01467087} \\
\hline \multirow[t]{22}{*}{ TACO 250} & $8 / 18 / 2009$ & 0:00:00 & 24.9 & 616 & 1.59 & -- & 4.7 & -- & -- \\
\hline & & 0:30:00 & 24.9 & 616 & 1.59 & -- & 4.3 & -- & -- \\
\hline & & 1:00:00 & 24.8 & 616 & 1.59 & -- & 4.7 & -- & -- \\
\hline & & $1: 30: 00$ & 24.7 & 616 & 1.59 & -- & 4.8 & -- & -- \\
\hline & & $2: 00: 00$ & 24.7 & 617 & 1.59 & -- & 5.1 & -- & -- \\
\hline & & $2: 30: 00$ & 24.6 & 617 & 1.59 & -- & 4.8 & -- & -- \\
\hline & & $6: 30: 00$ & 24.2 & 620 & 1.58 & -- & 2.8 & -- & -- \\
\hline & & 7:00:00 & 24.2 & 620 & 1.58 & -- & 3.1 & -- & -- \\
\hline & & $7: 30: 00$ & 24.1 & 620 & 1.58 & -- & 3.9 & -- & -- \\
\hline & & 8:00:00 & 24.1 & 620 & 1.58 & -- & 4.4 & -- & -- \\
\hline & & $8: 30: 00$ & 24.2 & 620 & 1.58 & -- & 4.7 & -- & -- \\
\hline & & 9:00:00 & 24.3 & 621 & 1.57 & -- & 5.3 & -- & -- \\
\hline & & 9:30:00 & 24.4 & 621 & 1.58 & -- & 5.6 & -- & -- \\
\hline & & 10:00:00 & 24.6 & 622 & 1.58 & 6.9 & 6.1 & -- & -- \\
\hline & & $11: 30: 00$ & 25.2 & 614 & 1.58 & 7.2 & -- & -- & -- \\
\hline & & $12: 00: 00$ & 25.3 & 614 & 1.58 & 7.3 & -- & -- & -- \\
\hline & & $12: 30: 00$ & 25.5 & 614 & 1.58 & 7.4 & -- & -- & -- \\
\hline & & 13:00:00 & 25.8 & 614 & 1.58 & 7.4 & 8.3 & -- & -- \\
\hline & & $13: 30: 00$ & 25.9 & 614 & 1.58 & 7.4 & 8.4 & -- & -- \\
\hline & & 14:00:00 & 26.1 & 615 & 1.58 & 7.4 & 8.5 & -- & -- \\
\hline & & $14: 30: 00$ & 26.2 & 615 & 1.58 & 7.5 & 8.6 & -- & -- \\
\hline & & $15: 00: 00$ & 26.3 & 615 & 1.58 & 7.5 & 8.7 & -- & -- \\
\hline
\end{tabular}


Table 1-2. Chemical and physical properties measured by water-quality monitors during the period of dye tracing in Tacony/ Frankford Creek, Philadelphia, Pa. on August 18, September 1, and September 3, 2009.-Continued

$\left[{ }^{\circ} \mathrm{C}\right.$, degrees Celsius; $\mu \mathrm{S} / \mathrm{cm}$, microsiemens per centimter; mg/L, milligrams per liter; FNU, Formazin Nephelometric units; USGS, U.S. Geological Survey; ,-- no data]

\begin{tabular}{|c|c|c|c|c|c|c|c|c|c|}
\hline \multirow[t]{10}{*}{ Site } & Date & Time & $\begin{array}{c}\text { Temper- } \\
\text { ature } \\
\left({ }^{\circ} \mathrm{C}\right)\end{array}$ & $\begin{array}{c}\text { Specific } \\
\text { conduc- } \\
\text { tance } \\
(\mu \mathrm{S} / \mathrm{cm})\end{array}$ & $\begin{array}{c}\text { Sonde depth } \\
\text { or gage } \\
\text { height }^{1} \\
\text { (feet) }\end{array}$ & $\mathrm{pH}$ & $\begin{array}{c}\text { Dissolved } \\
\text { oxygen } \\
\text { (DO) } \\
\text { concen- } \\
\text { tration } \\
\text { (mg/L) }\end{array}$ & $\begin{array}{c}\text { DO } \\
\text { saturation } \\
\text { (percent) }\end{array}$ & $\begin{array}{c}\text { Turbidity } \\
\text { (FNU) }\end{array}$ \\
\hline & & $15: 30: 00$ & 26.4 & 616 & 1.58 & 7.5 & 8.8 & -- & -- \\
\hline & & $17: 00: 00$ & 26.6 & 615 & 1.58 & 7.5 & 8.6 & -- & -- \\
\hline & & $17: 30: 00$ & 26.5 & 616 & 1.58 & 7.5 & 8.1 & -- & -- \\
\hline & & 18:00:00 & 26.3 & 616 & 1.58 & 7.5 & 8.1 & -- & -- \\
\hline & & 18:30:00 & 26.2 & 616 & 1.58 & 7.4 & 7.9 & -- & -- \\
\hline & & 19:00:00 & 26.1 & 616 & 1.58 & 7.4 & 7.7 & -- & -- \\
\hline & & 21:00:00 & 25.6 & 614 & 1.58 & 7.4 & 7.3 & -- & -- \\
\hline & & $21: 30: 00$ & 25.5 & 615 & 1.58 & 7.3 & 7.1 & -- & -- \\
\hline & & 22:00:00 & 25.4 & 614 & 1.58 & 7.3 & 7.2 & -- & -- \\
\hline \multicolumn{10}{|c|}{ USGS station number 014670868} \\
\hline \multirow[t]{22}{*}{ TACO263 } & $9 / 1 / 2009$ & $6: 45: 52$ & 19.1 & 533 & 1.55 & 7.48 & 7.4 & 80.0 & 0.6 \\
\hline & & $6: 50: 52$ & 19.1 & 533 & 1.56 & 7.44 & 7.4 & 80.0 & 0.4 \\
\hline & & $6: 55: 52$ & 19.1 & 534 & 1.56 & 7.43 & 7.4 & 80.0 & 0.5 \\
\hline & & $7: 00: 52$ & 19.1 & 534 & 1.56 & 7.43 & 7.4 & 80.1 & 0.6 \\
\hline & & $7: 05: 52$ & 19.1 & 534 & 1.56 & 7.44 & 7.4 & 80.1 & 0.4 \\
\hline & & $7: 10: 52$ & 19.1 & 535 & 1.56 & 7.43 & 7.4 & 80.2 & 0.4 \\
\hline & & $7: 50: 51$ & 19.0 & 540 & 1.57 & 7.45 & 7.5 & 81.3 & 2.9 \\
\hline & & $7: 55: 52$ & 19.0 & 539 & 1.57 & 7.46 & 7.6 & 81.8 & 0.9 \\
\hline & & $8: 00: 52$ & 19.0 & 540 & 1.57 & 7.47 & 7.6 & 82.0 & 1.7 \\
\hline & & $8: 05: 52$ & 19.0 & 541 & 1.58 & 7.47 & 7.6 & 82.1 & 1.2 \\
\hline & & $8: 10: 52$ & 19.0 & 541 & 1.57 & 7.47 & 7.6 & 82.3 & 1.2 \\
\hline & & $8: 15: 52$ & 18.9 & 542 & 1.57 & 7.47 & 7.6 & 82.3 & 1.8 \\
\hline & & $8: 20: 52$ & 18.9 & 543 & 1.58 & 7.47 & 7.6 & 82.2 & 1.0 \\
\hline & & $8: 25: 52$ & 18.9 & 543 & 1.58 & 7.47 & 7.7 & 82.5 & 1.0 \\
\hline & & $8: 30: 52$ & 18.9 & 543 & 1.58 & 7.48 & 7.7 & 82.9 & .8 \\
\hline & & $8: 35: 52$ & 19.0 & 543 & 1.58 & 7.48 & 7.7 & 83.1 & .6 \\
\hline & & $8: 40: 52$ & 18.9 & 545 & 1.58 & 7.47 & 7.7 & 83.1 & 1.4 \\
\hline & & $8: 45: 52$ & 19.0 & 544 & 1.59 & 7.49 & 7.8 & 83.8 & .5 \\
\hline & & $8: 50: 52$ & 19.0 & 546 & 1.59 & 7.47 & 7.7 & 83.5 & 1.5 \\
\hline & & $8: 55: 52$ & 19.0 & 545 & 1.59 & 7.49 & 7.8 & 84.5 & .6 \\
\hline & & $9: 00: 52$ & 19.0 & 547 & 1.59 & 7.49 & 7.8 & 84.5 & 1.0 \\
\hline & & $9: 05: 52$ & 19.0 & 546 & 1.59 & 7.49 & 7.9 & 85.1 & .5 \\
\hline
\end{tabular}


Table 1-2. Chemical and physical properties measured by water-quality monitors during the period of dye tracing in Tacony/ Frankford Creek, Philadelphia, Pa. on August 18, September 1, and September 3, 2009.-Continued

$\left[{ }^{\circ} \mathrm{C}\right.$, degrees Celsius; $\mu \mathrm{S} / \mathrm{cm}$, microsiemens per centimter; mg/L, milligrams per liter; FNU, Formazin Nephelometric units; USGS, U.S. Geological Survey; ,-- no data]

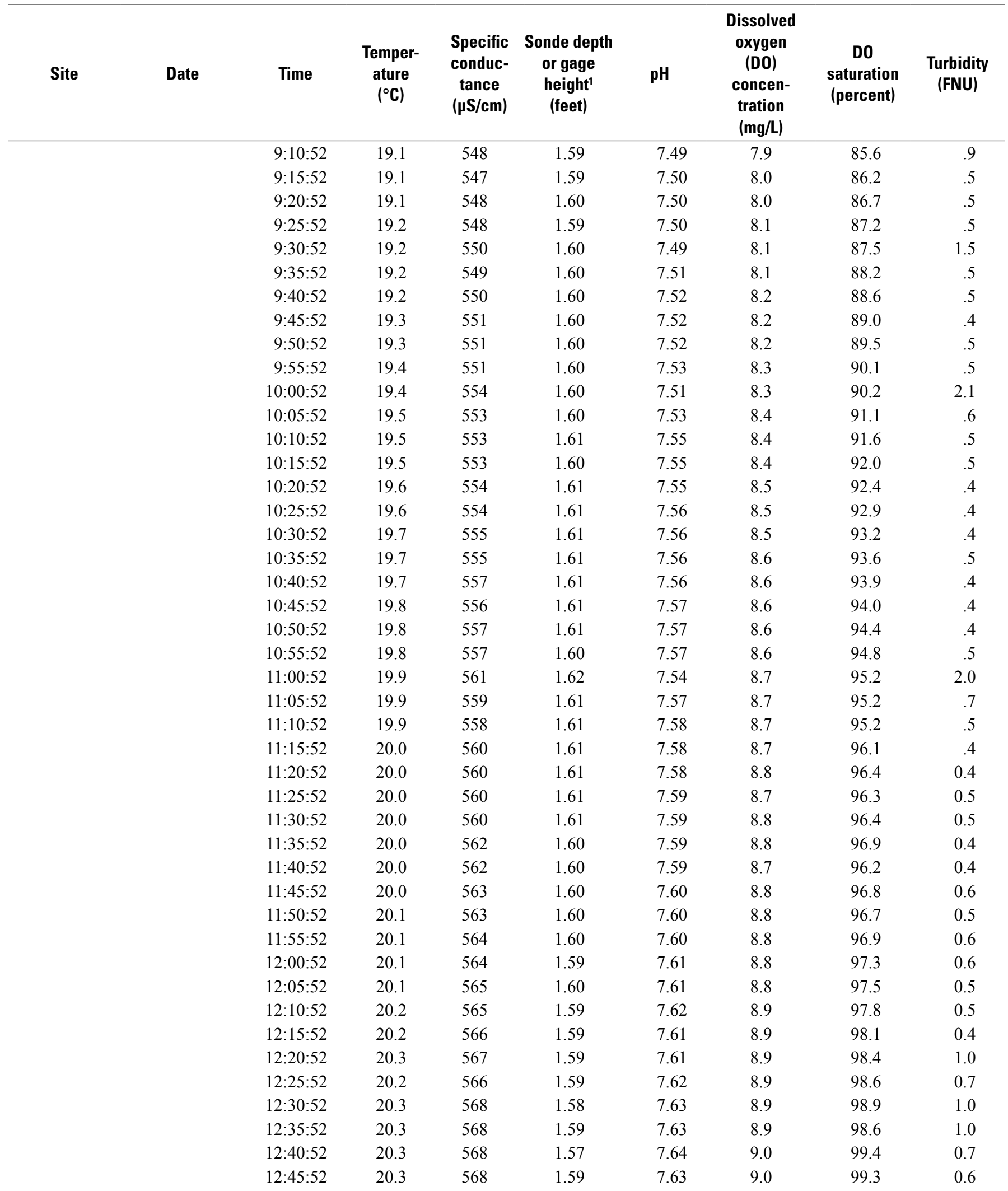


Table 1-2. Chemical and physical properties measured by water-quality monitors during the period of dye tracing in Tacony/ Frankford Creek, Philadelphia, Pa. on August 18, September 1, and September 3, 2009.-Continued

$\left[{ }^{\circ} \mathrm{C}\right.$, degrees Celsius; $\mu \mathrm{S} / \mathrm{cm}$, microsiemens per centimter; mg/L, milligrams per liter; FNU, Formazin Nephelometric units; USGS, U.S. Geological Survey; ,-- no data]

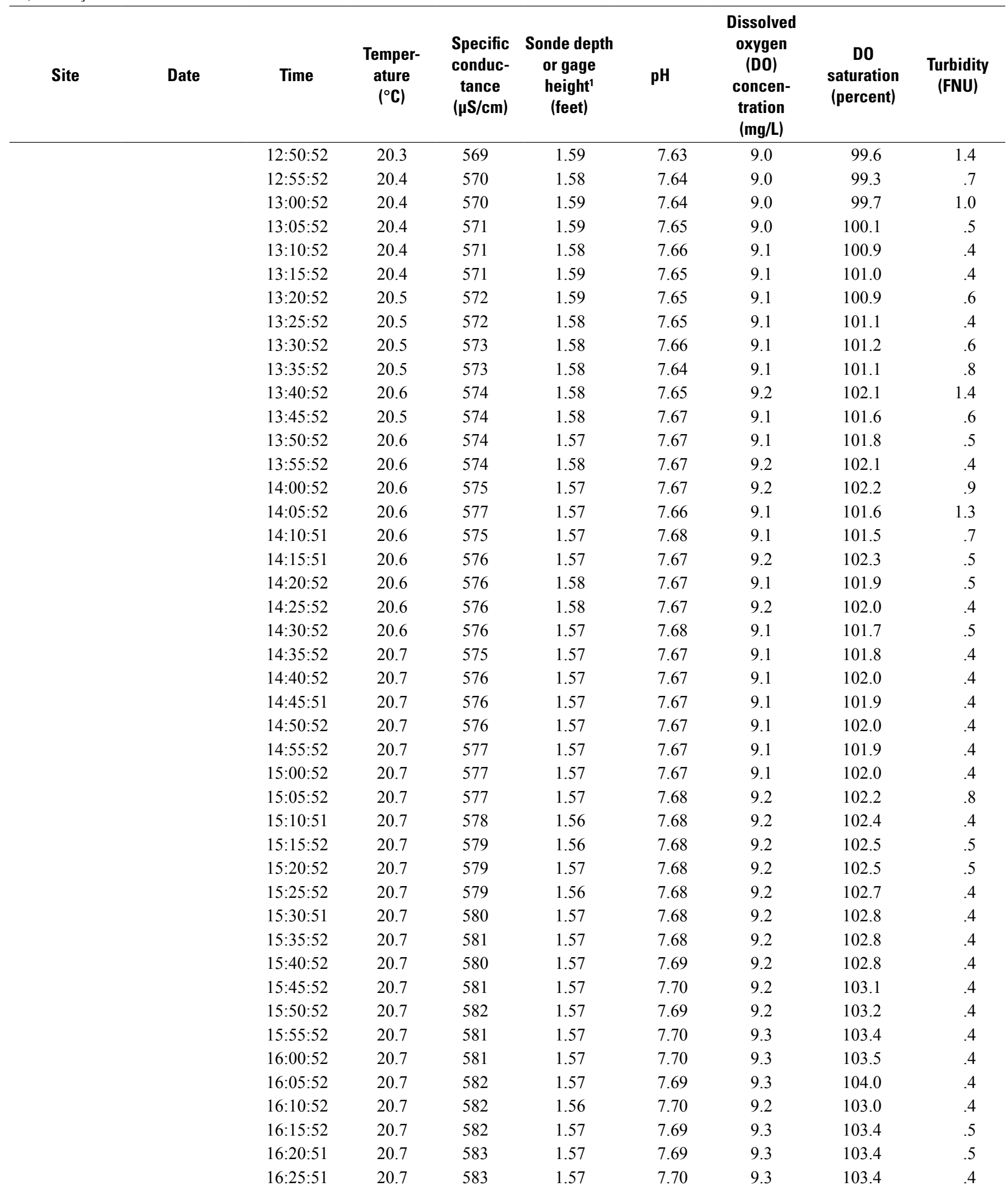


Table 1-2. Chemical and physical properties measured by water-quality monitors during the period of dye tracing in Tacony/ Frankford Creek, Philadelphia, Pa. on August 18, September 1, and September 3, 2009.-Continued

$\left[{ }^{\circ} \mathrm{C}\right.$, degrees Celsius; $\mu \mathrm{S} / \mathrm{cm}$, microsiemens per centimter; mg/L, milligrams per liter; FNU, Formazin Nephelometric units; USGS, U.S. Geological Survey; ,-- no data]

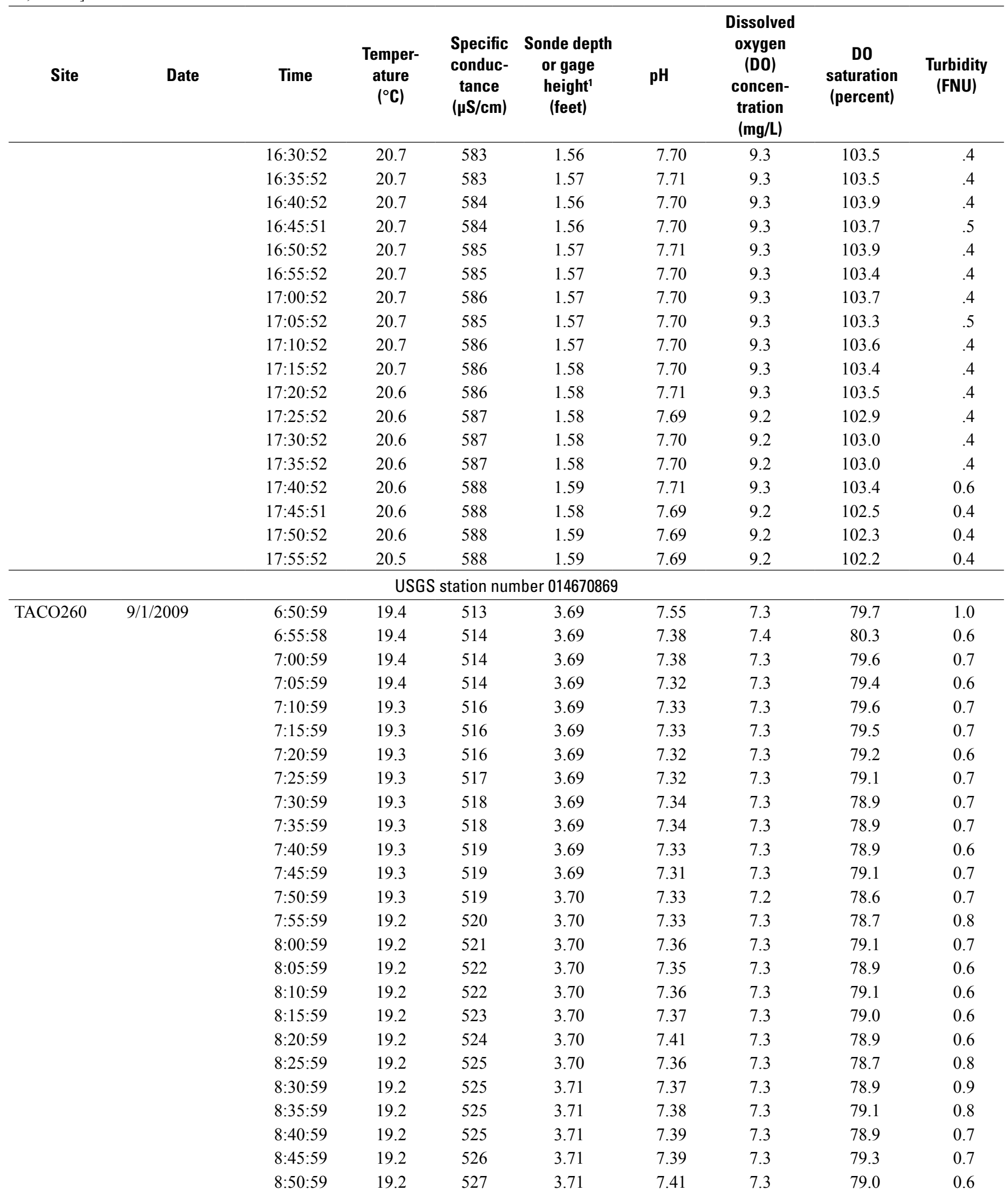


Table 1-2. Chemical and physical properties measured by water-quality monitors during the period of dye tracing in Tacony/ Frankford Creek, Philadelphia, Pa. on August 18, September 1, and September 3, 2009.-Continued

$\left[{ }^{\circ} \mathrm{C}\right.$, degrees Celsius; $\mu \mathrm{S} / \mathrm{cm}$, microsiemens per centimter; mg/L, milligrams per liter; FNU, Formazin Nephelometric units; USGS, U.S. Geological Survey; ,-- no data]

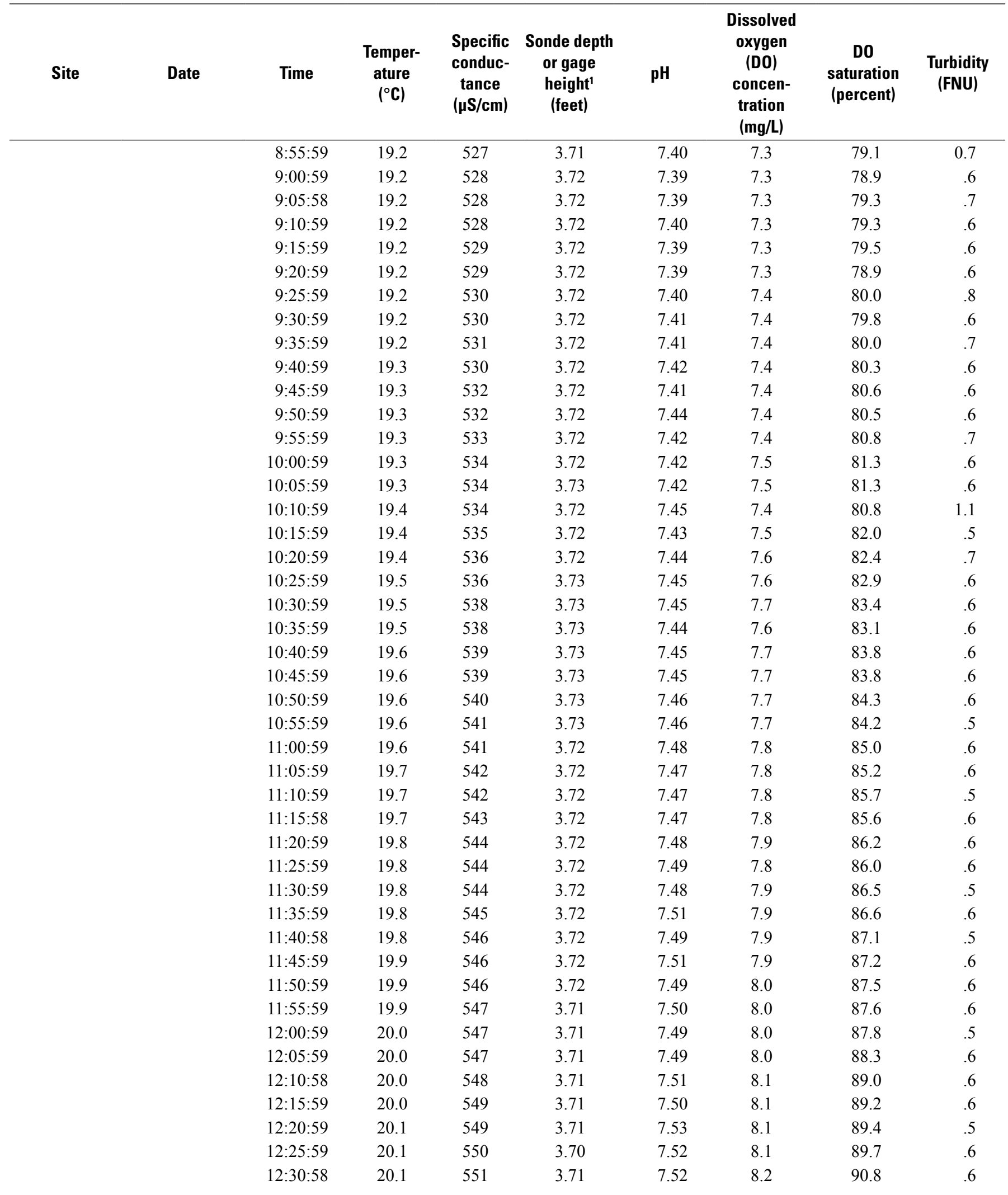


Table 1-2. Chemical and physical properties measured by water-quality monitors during the period of dye tracing in Tacony/ Frankford Creek, Philadelphia, Pa. on August 18, September 1, and September 3, 2009.-Continued

$\left[{ }^{\circ} \mathrm{C}\right.$, degrees Celsius; $\mu \mathrm{S} / \mathrm{cm}$, microsiemens per centimter; mg/L, milligrams per liter; FNU, Formazin Nephelometric units; USGS, U.S. Geological Survey; ,-- no data]

\begin{tabular}{|c|c|c|c|c|c|c|c|c|c|}
\hline Site & Date & Time & $\begin{array}{c}\text { Temper- } \\
\text { ature } \\
\left({ }^{\circ} \mathrm{C}\right)\end{array}$ & $\begin{array}{c}\text { Specific } \\
\text { conduc- } \\
\text { tance } \\
(\mu \mathrm{S} / \mathrm{cm})\end{array}$ & $\begin{array}{c}\text { Sonde depth } \\
\text { or gage } \\
\text { height }^{1} \\
\text { (feet) }\end{array}$ & $\mathrm{pH}$ & $\begin{array}{l}\text { Dissolved } \\
\text { oxygen } \\
\text { (DO) } \\
\text { concen- } \\
\text { tration } \\
\text { (mg/L) }\end{array}$ & $\begin{array}{c}\text { DO } \\
\text { saturation } \\
\text { (percent) }\end{array}$ & $\begin{array}{c}\text { Turbidity } \\
\text { (FNU) }\end{array}$ \\
\hline & & $12: 35: 59$ & 20.1 & 552 & 3.71 & 7.52 & 8.2 & 90.5 & 0.6 \\
\hline & & $12: 40: 58$ & 20.2 & 553 & 3.70 & 7.53 & 8.3 & 91.3 & .6 \\
\hline & & $12: 45: 59$ & 20.2 & 553 & 3.71 & 7.53 & 8.2 & 91.0 & .6 \\
\hline & & $12: 50: 58$ & 20.2 & 554 & 3.70 & 7.54 & 8.3 & 91.3 & .4 \\
\hline & & $12: 55: 59$ & 20.2 & 555 & 3.70 & 7.54 & 8.3 & 92.0 & .6 \\
\hline & & 13:00:59 & 20.3 & 555 & 3.70 & 7.56 & 8.4 & 93.0 & .6 \\
\hline & & $13: 05: 58$ & 20.3 & 556 & 3.70 & 7.55 & 8.4 & 92.8 & .4 \\
\hline & & $13: 10: 59$ & 20.4 & 556 & 3.70 & 7.55 & 8.4 & 93.2 & .6 \\
\hline & & $13: 15: 59$ & 20.4 & 557 & 3.70 & 7.55 & 8.4 & 93.7 & .6 \\
\hline & & $13: 20: 59$ & 20.4 & 557 & 3.70 & 7.55 & 8.5 & 93.9 & .6 \\
\hline & & $13: 25: 59$ & 20.5 & 558 & 3.70 & 7.55 & 8.5 & 94.1 & .6 \\
\hline & & $13: 30: 59$ & 20.5 & 558 & 3.70 & 7.56 & 8.5 & 94.3 & .6 \\
\hline & & $13: 35: 58$ & 20.6 & 559 & 3.70 & 7.56 & 8.5 & 94.7 & .7 \\
\hline & & $13: 40: 59$ & 20.6 & 560 & 3.69 & 7.58 & 8.6 & 95.3 & .6 \\
\hline & & $13: 45: 59$ & 20.6 & 560 & 3.69 & 7.57 & 8.5 & 95.2 & .6 \\
\hline & & $13: 50: 59$ & 20.6 & 560 & 3.69 & 7.57 & 8.5 & 95.1 & .7 \\
\hline & & $13: 55: 59$ & 20.7 & 561 & 3.69 & 7.57 & 8.5 & 95.1 & .6 \\
\hline & & $14: 00: 59$ & 20.7 & 561 & 3.69 & 7.59 & 8.6 & 95.9 & .6 \\
\hline & & $14: 05: 59$ & 20.7 & 562 & 3.68 & 7.58 & 8.6 & 96.0 & .6 \\
\hline & & $14: 10: 59$ & 20.7 & 562 & 3.69 & 7.59 & 8.6 & 96.2 & .6 \\
\hline & & $14: 15: 59$ & 20.8 & 563 & 3.68 & 7.57 & 8.6 & 96.5 & .6 \\
\hline & & $14: 20: 59$ & 20.8 & 563 & 3.69 & 7.59 & 8.6 & 96.6 & .7 \\
\hline & & $14: 25: 58$ & 20.8 & 563 & 3.68 & 7.61 & 8.7 & 97.4 & .5 \\
\hline & & $14: 30: 59$ & 20.8 & 564 & 3.69 & 7.59 & 8.7 & 97.5 & .7 \\
\hline & & $14: 35: 59$ & 20.8 & 565 & 3.68 & 7.59 & 8.7 & 97.4 & .6 \\
\hline & & $14: 40: 59$ & 20.9 & 565 & 3.68 & 7.60 & 8.7 & 97.9 & .8 \\
\hline & & $14: 45: 58$ & 20.9 & 566 & 3.69 & 7.60 & 8.7 & 98.0 & .8 \\
\hline & & $14: 50: 59$ & 20.9 & 566 & 3.69 & 7.59 & 8.7 & 97.7 & .6 \\
\hline & & $14: 55: 58$ & 20.9 & 567 & 3.69 & 7.60 & 8.8 & 98.3 & .7 \\
\hline & & $15: 00: 59$ & 20.8 & 568 & 3.69 & 7.61 & 8.7 & 97.8 & .7 \\
\hline & & $15: 05: 59$ & 20.9 & 569 & 3.69 & 7.61 & 8.8 & 98.5 & .7 \\
\hline & & $15: 10: 58$ & 20.9 & 570 & 3.68 & 7.62 & 8.8 & 98.7 & .6 \\
\hline & & $15: 15: 58$ & 20.9 & 570 & 3.68 & 7.61 & 8.8 & 98.8 & .7 \\
\hline & & $15: 20: 58$ & 20.9 & 570 & 3.68 & 7.60 & 8.8 & 98.7 & .7 \\
\hline & & $15: 25: 59$ & 20.9 & 571 & 3.68 & 7.61 & 8.9 & 99.1 & .6 \\
\hline & & $15: 30: 59$ & 20.9 & 572 & 3.68 & 7.63 & 8.9 & 99.4 & .6 \\
\hline & & $15: 35: 59$ & 20.9 & 572 & 3.68 & 7.62 & 8.9 & 99.2 & .4 \\
\hline & & $15: 40: 59$ & 20.9 & 572 & 3.68 & 7.62 & 8.9 & 99.5 & .6 \\
\hline & & $15: 45: 59$ & 20.9 & 573 & 3.68 & 7.62 & 8.9 & 99.9 & .6 \\
\hline & & $15: 50: 58$ & 20.9 & 574 & 3.69 & 7.63 & 8.9 & 100.2 & .5 \\
\hline & & $15: 55: 59$ & 20.9 & 574 & 3.69 & 7.63 & 9.0 & 100.4 & .6 \\
\hline & & $16: 00: 58$ & 20.9 & 574 & 3.69 & 7.64 & 8.9 & 100.3 & .6 \\
\hline & & $16: 05: 58$ & 20.9 & 575 & 3.68 & 7.64 & 8.9 & 99.7 & .8 \\
\hline & & $16: 10: 59$ & 20.9 & 575 & 3.69 & 7.65 & 9.0 & 100.5 & .5 \\
\hline
\end{tabular}


Table 1-2. Chemical and physical properties measured by water-quality monitors during the period of dye tracing in Tacony/ Frankford Creek, Philadelphia, Pa. on August 18, September 1, and September 3, 2009.-Continued

$\left[{ }^{\circ} \mathrm{C}\right.$, degrees Celsius; $\mu \mathrm{S} / \mathrm{cm}$, microsiemens per centimter; mg/L, milligrams per liter; FNU, Formazin Nephelometric units; USGS, U.S. Geological Survey; ,-- no data]

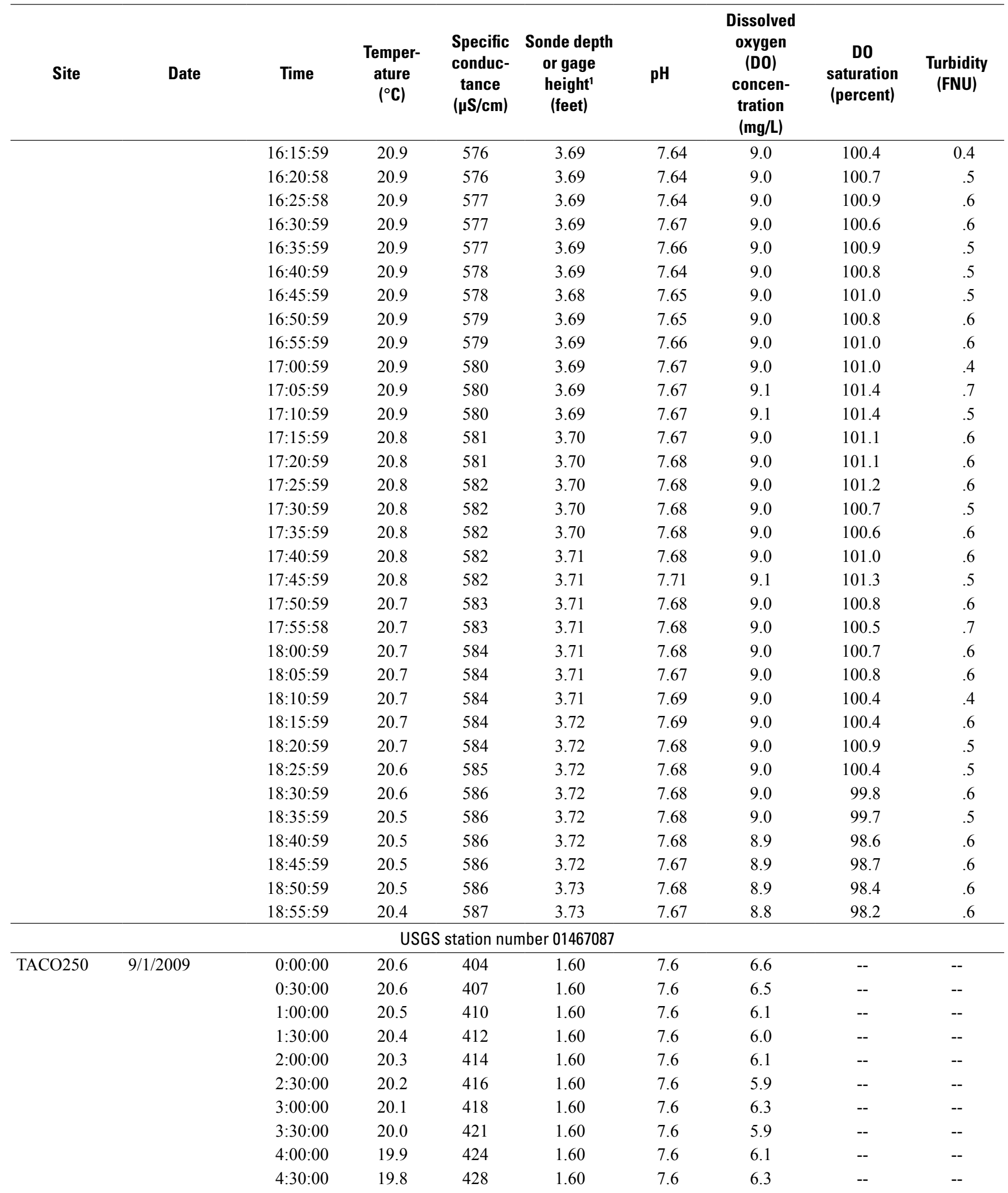


Table 1-2. Chemical and physical properties measured by water-quality monitors during the period of dye tracing in Tacony/ Frankford Creek, Philadelphia, Pa. on August 18, September 1, and September 3, 2009.-Continued

$\left[{ }^{\circ} \mathrm{C}\right.$, degrees Celsius; $\mu \mathrm{S} / \mathrm{cm}$, microsiemens per centimter; mg/L, milligrams per liter; FNU, Formazin Nephelometric units; USGS, U.S. Geological Survey; ,-- no data]

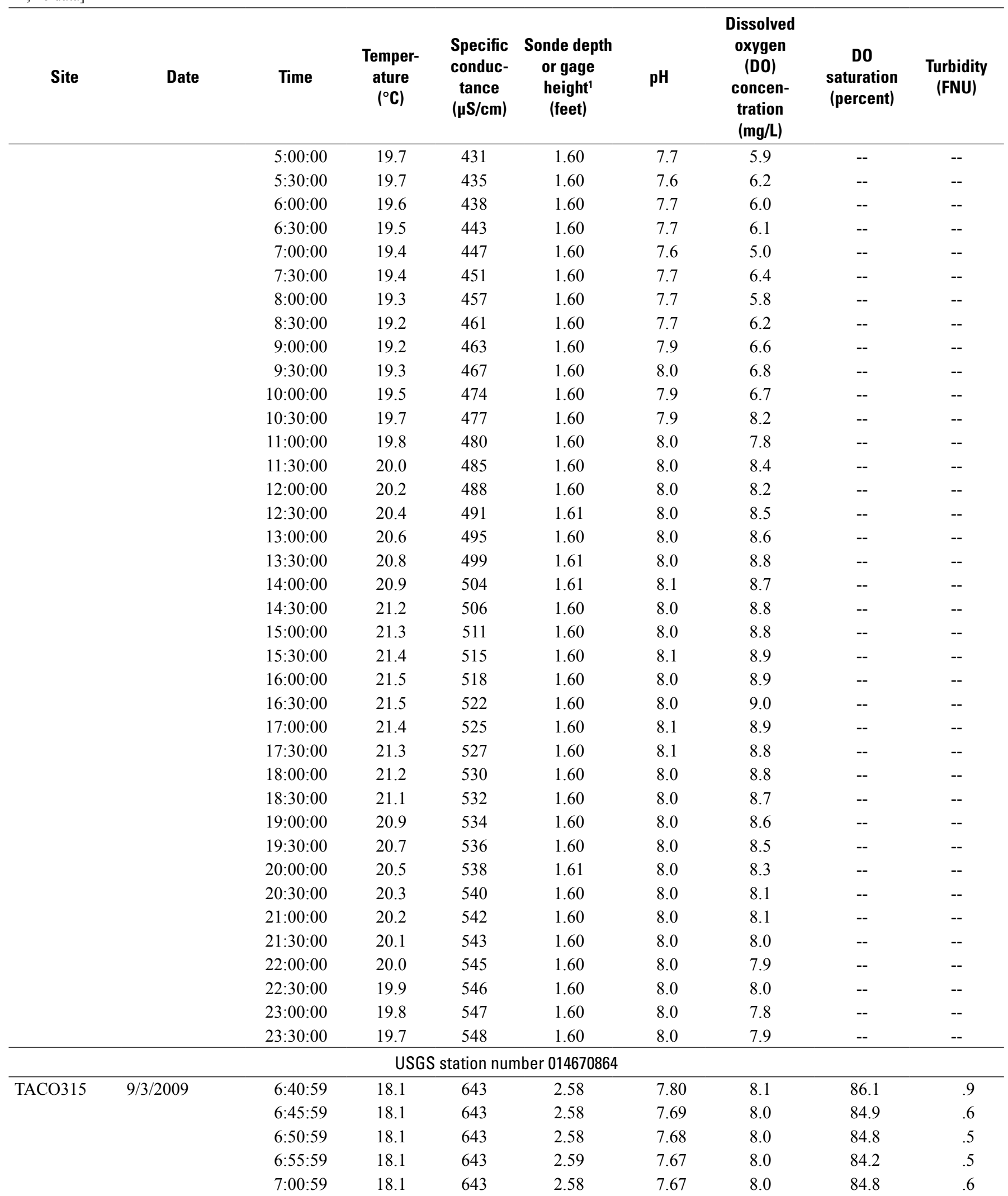


Table 1-2. Chemical and physical properties measured by water-quality monitors during the period of dye tracing in Tacony/ Frankford Creek, Philadelphia, Pa. on August 18, September 1, and September 3, 2009.-Continued

$\left[{ }^{\circ} \mathrm{C}\right.$, degrees Celsius; $\mu \mathrm{S} / \mathrm{cm}$, microsiemens per centimter; mg/L, milligrams per liter; FNU, Formazin Nephelometric units; USGS, U.S. Geological Survey; ,-- no data]

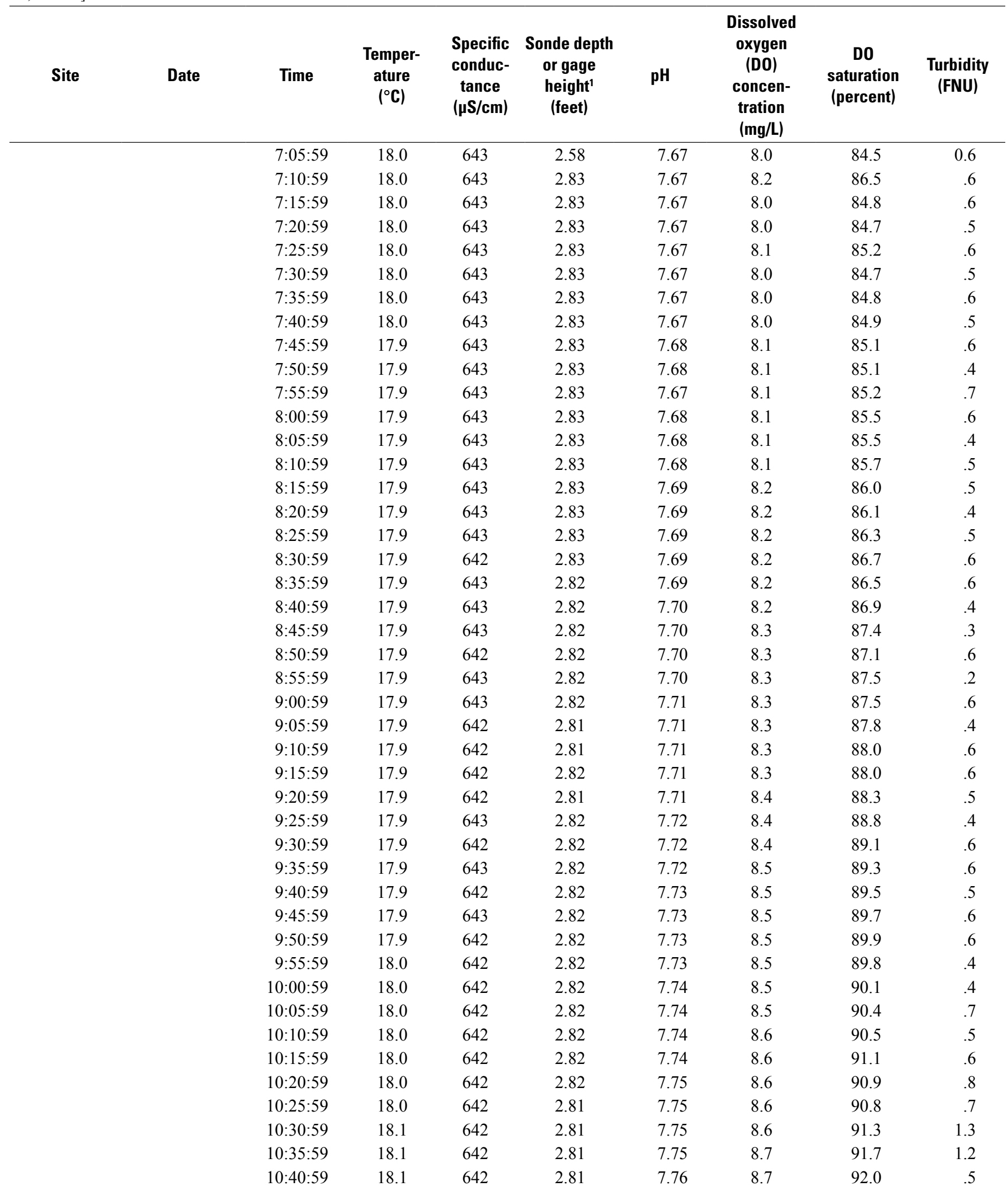


Table 1-2. Chemical and physical properties measured by water-quality monitors during the period of dye tracing in Tacony/ Frankford Creek, Philadelphia, Pa. on August 18, September 1, and September 3, 2009.-Continued

$\left[{ }^{\circ} \mathrm{C}\right.$, degrees Celsius; $\mu \mathrm{S} / \mathrm{cm}$, microsiemens per centimter; mg/L, milligrams per liter; FNU, Formazin Nephelometric units; USGS, U.S. Geological Survey; ,-- no data]

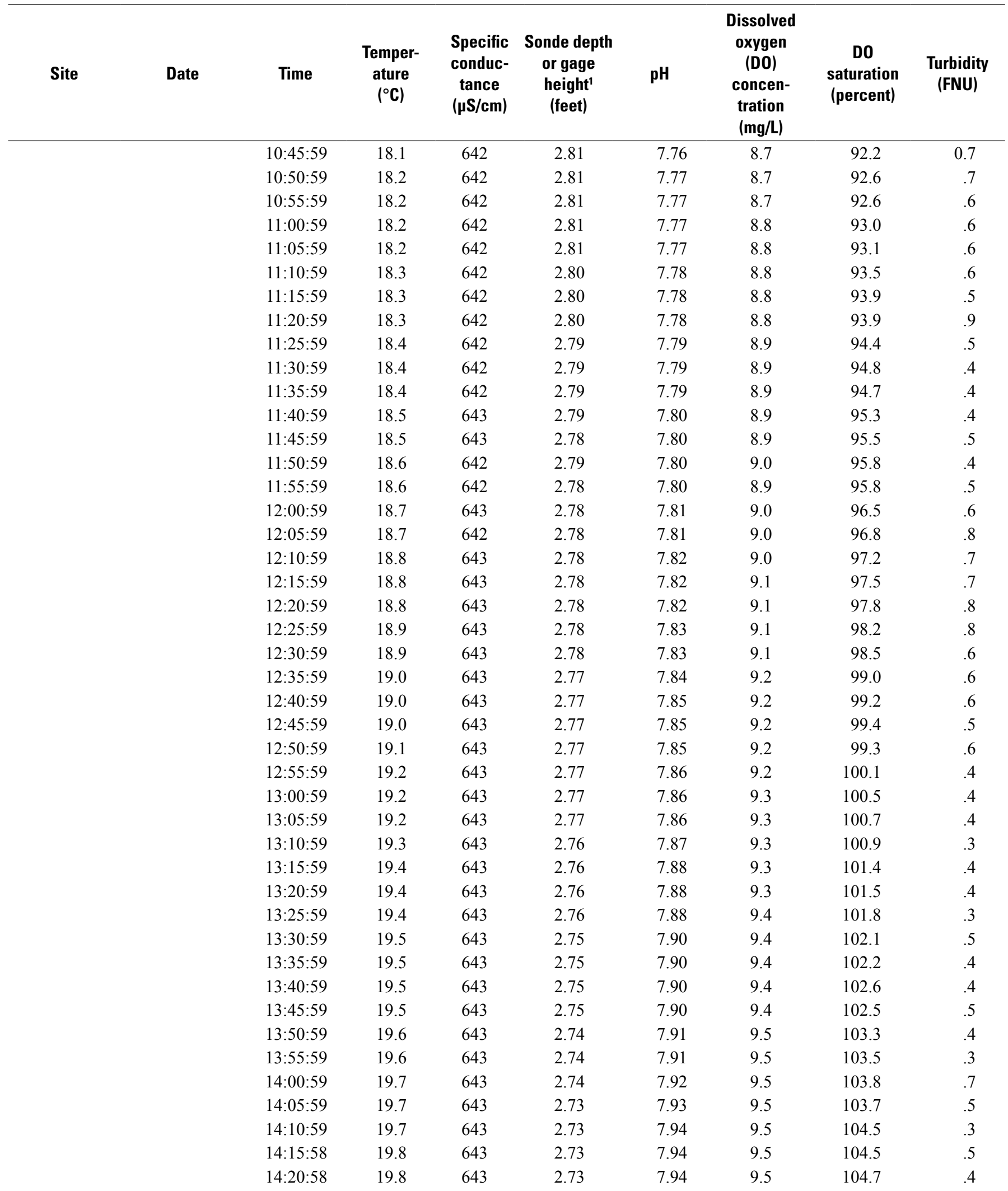


Table 1-2. Chemical and physical properties measured by water-quality monitors during the period of dye tracing in Tacony/ Frankford Creek, Philadelphia, Pa. on August 18, September 1, and September 3, 2009.-Continued

$\left[{ }^{\circ} \mathrm{C}\right.$, degrees Celsius; $\mu \mathrm{S} / \mathrm{cm}$, microsiemens per centimter; mg/L, milligrams per liter; FNU, Formazin Nephelometric units; USGS, U.S. Geological Survey; ,-- no data]

\begin{tabular}{|c|c|c|c|c|c|c|c|c|c|}
\hline Site & Date & Time & $\begin{array}{c}\text { Temper- } \\
\text { ature } \\
\left({ }^{\circ} \mathrm{C}\right)\end{array}$ & $\begin{array}{c}\text { Specific } \\
\text { conduc- } \\
\text { tance } \\
(\mu \mathrm{S} / \mathrm{cm})\end{array}$ & $\begin{array}{c}\text { Sonde depth } \\
\text { or gage } \\
\text { height }^{1} \\
\text { (feet) }\end{array}$ & pH & $\begin{array}{l}\text { Dissolved } \\
\text { oxygen } \\
\text { (DO) } \\
\text { concen- } \\
\text { tration } \\
\text { (mg/L) }\end{array}$ & $\begin{array}{c}\text { DO } \\
\text { saturation } \\
\text { (percent) }\end{array}$ & $\begin{array}{c}\text { Turbidity } \\
\text { (FNU) }\end{array}$ \\
\hline & & $14: 25: 59$ & 19.8 & 643 & 2.72 & 7.94 & 9.6 & 104.8 & 0.4 \\
\hline & & $14: 30: 59$ & 19.9 & 643 & 2.72 & 7.95 & 9.6 & 105.1 & .5 \\
\hline & & $14: 40: 58$ & 19.9 & 643 & 2.72 & 7.95 & 9.6 & 105.1 & .4 \\
\hline & & $14: 45: 58$ & 20.0 & 643 & 2.71 & 7.96 & 9.6 & 105.3 & .5 \\
\hline & & $14: 50: 59$ & 20.0 & 643 & 2.71 & 7.96 & 9.6 & 105.6 & .6 \\
\hline & & $14: 55: 59$ & 20.0 & 643 & 2.71 & 7.97 & 9.6 & 105.5 & .4 \\
\hline & & $15: 00: 59$ & 20.1 & 643 & 2.71 & 7.97 & 9.6 & 106.0 & .5 \\
\hline & & $15: 20: 59$ & 20.1 & 643 & 2.71 & 7.99 & 9.6 & 106.5 & .4 \\
\hline & & $15: 25: 59$ & 20.2 & 643 & 2.71 & 8.01 & 9.6 & 106.3 & .6 \\
\hline & & $15: 30: 59$ & 20.2 & 643 & 2.71 & 8.01 & 9.6 & 106.6 & .3 \\
\hline & & $15: 35: 58$ & 20.2 & 643 & 2.71 & 8.01 & 9.7 & 106.9 & .4 \\
\hline & & $15: 40: 59$ & 20.3 & 643 & 2.70 & 8.02 & 9.7 & 107.0 & .5 \\
\hline & & $15: 45: 59$ & 20.3 & 643 & 2.70 & 8.03 & 9.7 & 107.0 & .4 \\
\hline & & $15: 50: 59$ & 20.3 & 643 & 2.70 & 8.03 & 9.7 & 107.3 & .4 \\
\hline & & $15: 55: 59$ & 20.3 & 643 & 2.69 & 8.04 & 9.7 & 107.7 & .5 \\
\hline & & $16: 00: 58$ & 20.4 & 643 & 2.69 & 8.04 & 9.7 & 107.6 & .4 \\
\hline & & $16: 05: 58$ & 20.4 & 644 & 2.69 & 8.04 & 9.7 & 107.4 & .4 \\
\hline & & $16: 10: 58$ & 20.4 & 643 & 2.70 & 8.05 & 9.7 & 107.4 & .3 \\
\hline & & $16: 45: 59$ & 20.5 & 644 & 2.69 & 8.08 & 9.7 & 108.2 & .4 \\
\hline & & $16: 50: 59$ & 20.5 & 644 & 2.69 & 8.10 & 9.7 & 107.9 & .6 \\
\hline & & $16: 55: 59$ & 20.5 & 644 & 2.69 & 8.10 & 9.7 & 107.7 & .3 \\
\hline & & $17: 00: 59$ & 20.5 & 644 & 2.69 & 8.10 & 9.7 & 108.0 & .5 \\
\hline & & $17: 05: 59$ & 20.5 & 644 & 2.69 & 8.11 & 9.7 & 108.1 & .4 \\
\hline & & $17: 10: 59$ & 20.5 & 644 & 2.69 & 8.11 & 9.7 & 107.8 & .4 \\
\hline & & $17: 15: 59$ & 20.5 & 644 & 2.69 & 8.12 & 9.7 & 107.9 & .5 \\
\hline & & $17: 20: 58$ & 20.6 & 644 & 2.69 & 8.12 & 9.7 & 107.7 & .5 \\
\hline & & $17: 25: 59$ & 20.6 & 644 & 2.69 & 8.13 & 9.7 & 107.9 & .5 \\
\hline & & $17: 30: 59$ & 20.6 & 644 & 2.69 & 8.13 & 9.7 & 107.5 & .3 \\
\hline \multicolumn{10}{|c|}{ USGS station number 014670865} \\
\hline \multirow[t]{5}{*}{ TACO285 } & $9 / 3 / 2009$ & $9: 20: 52$ & 18.2 & 648 & 2.12 & 7.71 & 8.7 & 92.2 & .5 \\
\hline & & $9: 25: 52$ & 18.2 & 649 & 2.12 & 7.71 & 8.7 & 92.4 & .6 \\
\hline & & $9: 30: 52$ & 18.2 & 649 & 2.13 & 7.70 & 8.7 & 92.8 & .4 \\
\hline & & $9: 35: 52$ & 18.2 & 649 & 2.13 & 7.69 & 8.7 & 92.9 & .5 \\
\hline & & $9: 40: 52$ & 18.2 & 650 & 2.13 & 7.71 & 8.8 & 93.2 & .4 \\
\hline
\end{tabular}


Table 1-2. Chemical and physical properties measured by water-quality monitors during the period of dye tracing in Tacony/ Frankford Creek, Philadelphia, Pa. on August 18, September 1, and September 3, 2009.-Continued

$\left[{ }^{\circ} \mathrm{C}\right.$, degrees Celsius; $\mu \mathrm{S} / \mathrm{cm}$, microsiemens per centimter; mg/L, milligrams per liter; FNU, Formazin Nephelometric units; USGS, U.S. Geological Survey; ,-- no data]

\begin{tabular}{|c|c|c|c|c|c|c|c|c|c|}
\hline Site & Date & Time & $\begin{array}{c}\text { Temper- } \\
\text { ature } \\
\left({ }^{\circ} \mathrm{C}\right)\end{array}$ & $\begin{array}{c}\text { Specific } \\
\text { conduc- } \\
\text { tance } \\
(\mu \mathrm{S} / \mathrm{cm})\end{array}$ & $\begin{array}{c}\text { Sonde depth } \\
\text { or gage } \\
\text { height }^{1} \\
\text { (feet) }\end{array}$ & $\mathbf{p H}$ & $\begin{array}{l}\text { Dissolved } \\
\text { oxygen } \\
\text { (DO) } \\
\text { concen- } \\
\text { tration } \\
\text { (mg/L) }\end{array}$ & $\begin{array}{c}\text { DO } \\
\text { saturation } \\
\text { (percent) }\end{array}$ & $\begin{array}{c}\text { Turbidity } \\
\text { (FNU) }\end{array}$ \\
\hline & & $9: 45: 52$ & 18.3 & 650 & 2.13 & 7.71 & 8.8 & 93.6 & 0.4 \\
\hline & & $9: 50: 52$ & 18.2 & 650 & 2.13 & 7.71 & 8.8 & 93.8 & .6 \\
\hline & & $9: 55: 52$ & 18.2 & 650 & 2.13 & 7.71 & 8.8 & 93.9 & .4 \\
\hline & & 10:00:52 & 18.2 & 650 & 2.13 & 7.72 & 8.9 & 94.1 & .4 \\
\hline & & $10: 05: 52$ & 18.3 & 650 & 2.13 & 7.72 & 8.9 & 94.7 & .4 \\
\hline & & $10: 10: 52$ & 18.3 & 650 & 2.13 & 7.72 & 8.9 & 94.8 & .4 \\
\hline & & $10: 15: 52$ & 18.3 & 651 & 2.12 & 7.72 & 8.9 & 95.2 & .4 \\
\hline & & $10: 20: 52$ & 18.3 & 651 & 2.12 & 7.73 & 9.0 & 95.5 & .4 \\
\hline & & $10: 25: 52$ & 18.3 & 651 & 2.12 & 7.72 & 9.0 & 95.7 & .4 \\
\hline & & $10: 30: 52$ & 18.3 & 651 & 2.12 & 7.73 & 9.0 & 96.0 & .4 \\
\hline & & $10: 35: 52$ & 18.3 & 651 & 2.11 & 7.74 & 9.1 & 96.4 & .4 \\
\hline & & $10: 40: 52$ & 18.4 & 652 & 2.11 & 7.74 & 9.1 & 96.8 & .4 \\
\hline & & $10: 45: 53$ & 18.4 & 652 & 2.11 & 7.74 & 9.1 & 96.9 & .4 \\
\hline & & $10: 50: 52$ & 18.4 & 652 & 2.11 & 7.74 & 9.1 & 97.1 & .4 \\
\hline & & $10: 55: 52$ & 18.4 & 652 & 2.11 & 7.74 & 9.1 & 97.1 & .4 \\
\hline & & $11: 00: 52$ & 18.5 & 652 & 2.11 & 7.74 & 9.1 & 97.5 & .4 \\
\hline & & $11: 05: 52$ & 18.5 & 651 & 2.11 & 7.74 & 9.2 & 97.7 & .3 \\
\hline & & $11: 10: 52$ & 18.5 & 652 & 2.11 & 7.75 & 9.2 & 98.1 & .4 \\
\hline & & $11: 15: 52$ & 18.6 & 652 & 2.11 & 7.75 & 9.2 & 98.4 & .4 \\
\hline & & $11: 20: 52$ & 18.5 & 652 & 2.10 & 7.76 & 9.2 & 98.5 & .4 \\
\hline & & $11: 25: 52$ & 18.6 & 652 & 2.10 & 7.77 & 9.3 & 99.4 & .4 \\
\hline & & $11: 30: 52$ & 18.7 & 653 & 2.10 & 7.77 & 9.3 & 99.3 & .4 \\
\hline & & $11: 35: 52$ & 18.7 & 653 & 2.09 & 7.77 & 9.3 & 99.9 & .3 \\
\hline & & $11: 40: 52$ & 18.7 & 652 & 2.09 & 7.78 & 9.3 & 100.2 & .3 \\
\hline & & $11: 45: 52$ & 18.8 & 653 & 2.09 & 7.78 & 9.3 & 100.4 & .4 \\
\hline & & $11: 50: 52$ & 18.8 & 653 & 2.09 & 7.79 & 9.4 & 100.7 & .3 \\
\hline & & $11: 55: 52$ & 18.9 & 653 & 2.09 & 7.79 & 9.4 & 101.3 & .4 \\
\hline & & $12: 00: 52$ & 18.9 & 653 & 2.09 & 7.80 & 9.4 & 101.5 & .4 \\
\hline & & $12: 05: 52$ & 19.0 & 653 & 2.09 & 7.81 & 9.5 & 102.0 & .4 \\
\hline & & $12: 10: 52$ & 19.0 & 653 & 2.08 & 7.80 & 9.5 & 102.2 & .4 \\
\hline & & $12: 15: 52$ & 19.1 & 653 & 2.08 & 7.81 & 9.5 & 102.8 & .3 \\
\hline & & $12: 20: 52$ & 19.1 & 653 & 2.08 & 7.81 & 9.5 & 102.7 & .4 \\
\hline & & $12: 25: 52$ & 19.1 & 653 & 2.08 & 7.82 & 9.6 & 103.4 & .4 \\
\hline & & $12: 30: 52$ & 19.2 & 653 & 2.07 & 7.82 & 9.6 & 103.7 & .3 \\
\hline & & $12: 35: 52$ & 19.2 & 653 & 2.07 & 7.83 & 9.6 & 103.8 & .3 \\
\hline & & $12: 40: 52$ & 19.3 & 653 & 2.07 & 7.83 & 9.6 & 104.4 & .4 \\
\hline & & $12: 45: 53$ & 19.3 & 653 & 2.07 & 7.84 & 9.6 & 104.5 & .3 \\
\hline & & $12: 50: 52$ & 19.4 & 653 & 2.07 & 7.84 & 9.7 & 105.0 & .4 \\
\hline & & $12: 55: 52$ & 19.5 & 653 & 2.07 & 7.84 & 9.7 & 105.4 & .4 \\
\hline & & $13: 00: 52$ & 19.5 & 653 & 2.07 & 7.85 & 9.7 & 105.6 & .3 \\
\hline & & $13: 05: 52$ & 19.5 & 653 & 2.06 & 7.86 & 9.7 & 105.9 & .4 \\
\hline & & $13: 10: 52$ & 19.5 & 653 & 2.06 & 7.86 & 9.7 & 106.3 & .4 \\
\hline & & $13: 15: 52$ & 19.6 & 653 & 2.06 & 7.86 & 9.7 & 106.4 & .4 \\
\hline & & $13: 20: 52$ & 19.6 & 653 & 2.06 & 7.87 & 9.8 & 106.8 & .4 \\
\hline
\end{tabular}


Table 1-2. Chemical and physical properties measured by water-quality monitors during the period of dye tracing in Tacony/ Frankford Creek, Philadelphia, Pa. on August 18, September 1, and September 3, 2009.-Continued

$\left[{ }^{\circ} \mathrm{C}\right.$, degrees Celsius; $\mu \mathrm{S} / \mathrm{cm}$, microsiemens per centimter; mg/L, milligrams per liter; FNU, Formazin Nephelometric units; USGS, U.S. Geological Survey; ,-- no data]

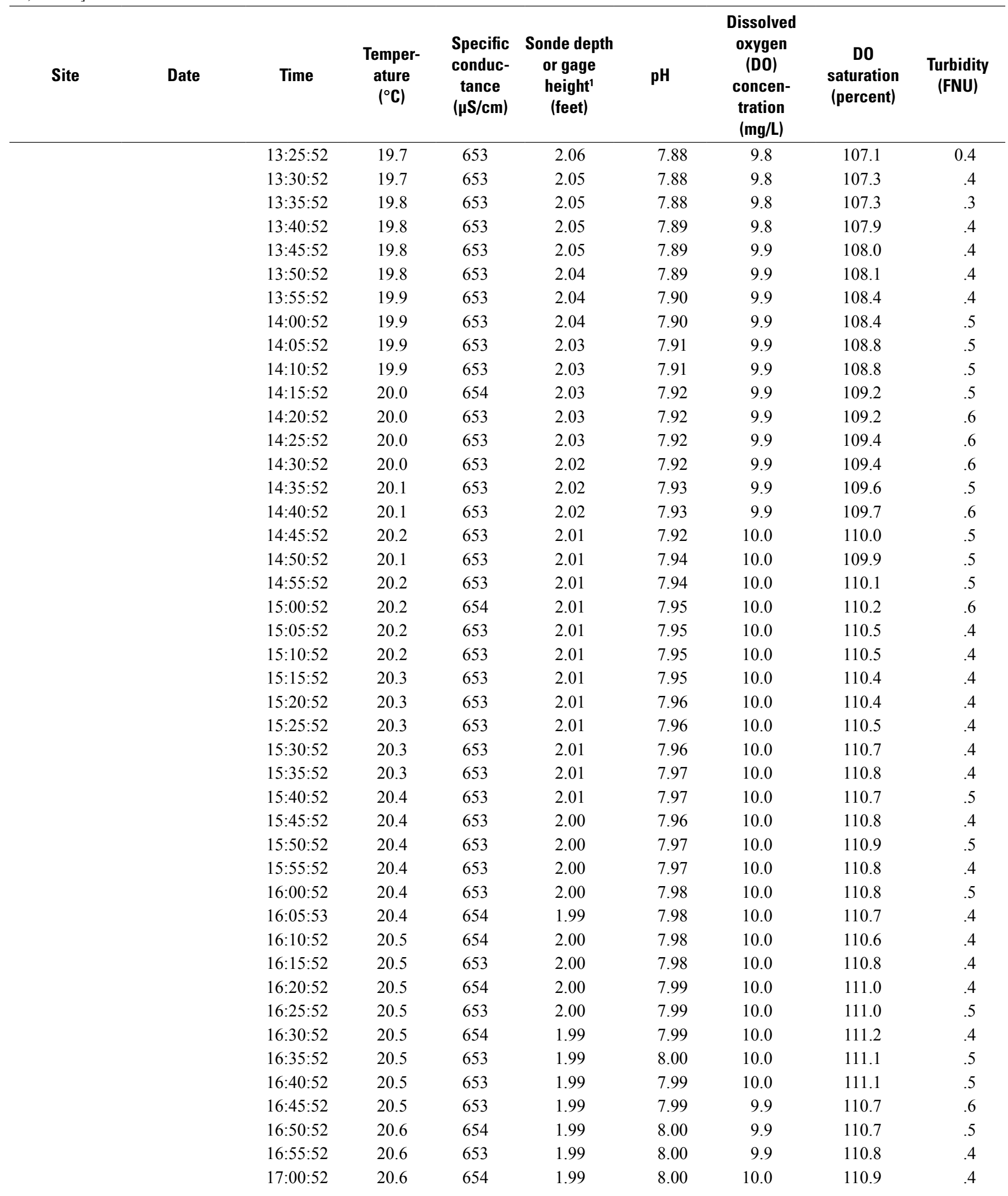


Table 1-2. Chemical and physical properties measured by water-quality monitors during the period of dye tracing in Tacony/ Frankford Creek, Philadelphia, Pa. on August 18, September 1, and September 3, 2009.-Continued

$\left[{ }^{\circ} \mathrm{C}\right.$, degrees Celsius; $\mu \mathrm{S} / \mathrm{cm}$, microsiemens per centimter; mg/L, milligrams per liter; FNU, Formazin Nephelometric units; USGS, U.S. Geological Survey; ,-- no data]

\begin{tabular}{|c|c|c|c|c|c|c|c|c|c|}
\hline Site & Date & Time & $\begin{array}{c}\text { Temper- } \\
\text { ature } \\
\left({ }^{\circ} \mathrm{C}\right)\end{array}$ & $\begin{array}{c}\text { Specific } \\
\text { conduc- } \\
\text { tance } \\
(\mu \mathrm{S} / \mathrm{cm})\end{array}$ & $\begin{array}{c}\text { Sonde depth } \\
\text { or gage } \\
\text { height }^{1} \\
\text { (feet) }\end{array}$ & pH & $\begin{array}{c}\text { Dissolved } \\
\text { oxygen } \\
\text { (DO) } \\
\text { concen- } \\
\text { tration } \\
\text { (mg/L) }\end{array}$ & $\begin{array}{c}\text { DO } \\
\text { saturation } \\
\text { (percent) }\end{array}$ & $\begin{array}{c}\text { Turbidity } \\
\text { (FNU) }\end{array}$ \\
\hline & & 17:05:52 & 20.6 & 654 & 1.99 & 8.00 & 9.9 & 110.7 & 0.5 \\
\hline & & $17: 20: 52$ & 20.6 & 654 & 1.99 & 8.01 & 9.9 & 110.4 & .6 \\
\hline & & $17: 25: 52$ & 20.6 & 653 & 1.99 & 8.01 & 9.9 & 110.3 & .5 \\
\hline & & $17: 30: 52$ & 20.6 & 654 & 1.99 & 8.01 & 9.9 & 110.3 & .6 \\
\hline & & $17: 35: 52$ & 20.6 & 654 & 1.99 & 8.00 & 9.9 & 109.9 & .5 \\
\hline & & $17: 40: 52$ & 20.6 & 654 & 1.99 & 8.00 & 9.9 & 109.8 & .5 \\
\hline & & 18:00:52 & 20.6 & 654 & 1.99 & 7.99 & 9.8 & 108.7 & .6 \\
\hline & & 18:05:52 & 20.5 & 653 & 1.99 & 7.99 & 9.8 & 108.6 & .6 \\
\hline \multicolumn{10}{|c|}{ USGS station number 014670866} \\
\hline \multirow[t]{23}{*}{ TACO275 } & $9 / 3 / 2009$ & $8: 40: 52$ & 18.4 & 628 & 2.42 & 7.56 & 7.9 & 84.5 & 2.4 \\
\hline & & $8: 45: 52$ & 18.4 & 630 & 2.32 & 7.55 & 7.9 & 84.1 & .7 \\
\hline & & $8: 50: 52$ & 18.4 & 630 & 2.32 & 7.55 & 7.9 & 84.1 & .7 \\
\hline & & $8: 55: 52$ & 18.4 & 630 & 2.32 & 7.55 & 7.9 & 84.0 & .6 \\
\hline & & $9: 00: 52$ & 18.4 & 630 & 2.32 & 7.55 & 7.9 & 84.0 & .6 \\
\hline & & $9: 05: 52$ & 18.4 & 630 & 2.32 & 7.55 & 7.9 & 84.1 & .6 \\
\hline & & $9: 10: 52$ & 18.4 & 630 & 2.32 & 7.56 & 7.9 & 84.2 & .6 \\
\hline & & $9: 50: 52$ & 18.4 & 630 & 2.32 & 7.57 & 8.0 & 85.7 & .6 \\
\hline & & $9: 55: 52$ & 18.4 & 630 & 2.32 & 7.57 & 8.0 & 85.4 & .6 \\
\hline & & 10:00:52 & 18.4 & 630 & 2.32 & 7.57 & 8.0 & 85.8 & .6 \\
\hline & & $10: 05: 52$ & 18.4 & 630 & 2.32 & 7.58 & 8.1 & 86.0 & .6 \\
\hline & & $10: 10: 52$ & 18.4 & 630 & 2.32 & 7.57 & 8.1 & 85.9 & .6 \\
\hline & & $10: 15: 52$ & 18.4 & 630 & 2.32 & 7.57 & 8.1 & 86.0 & .7 \\
\hline & & $10: 20: 52$ & 18.4 & 630 & 2.32 & 7.58 & 8.1 & 86.6 & .5 \\
\hline & & $10: 25: 52$ & 18.4 & 630 & 2.31 & 7.58 & 8.1 & 86.5 & .6 \\
\hline & & $10: 30: 52$ & 18.4 & 630 & 2.31 & 7.58 & 8.1 & 86.7 & .7 \\
\hline & & $10: 35: 52$ & 18.4 & 630 & 2.31 & 7.58 & 8.2 & 87.0 & .7 \\
\hline & & $10: 40: 52$ & 18.4 & 630 & 2.31 & 7.58 & 8.2 & 87.0 & .6 \\
\hline & & $10: 45: 52$ & 18.4 & 630 & 2.31 & 7.59 & 8.2 & 87.3 & .6 \\
\hline & & $10: 50: 52$ & 18.5 & 630 & 2.31 & 7.58 & 8.2 & 87.5 & 2.5 \\
\hline & & $10: 55: 52$ & 18.5 & 630 & 2.31 & 7.59 & 8.2 & 87.5 & .7 \\
\hline & & 11:00:52 & 18.5 & 630 & 2.31 & 7.59 & 8.2 & 88.0 & .6 \\
\hline & & $11: 05: 52$ & 18.5 & 630 & 2.30 & 7.60 & 8.3 & 88.4 & .5 \\
\hline
\end{tabular}


Table 1-2. Chemical and physical properties measured by water-quality monitors during the period of dye tracing in Tacony/ Frankford Creek, Philadelphia, Pa. on August 18, September 1, and September 3, 2009.-Continued

$\left[{ }^{\circ} \mathrm{C}\right.$, degrees Celsius; $\mu \mathrm{S} / \mathrm{cm}$, microsiemens per centimter; mg/L, milligrams per liter; FNU, Formazin Nephelometric units; USGS, U.S. Geological Survey; ,-- no data]

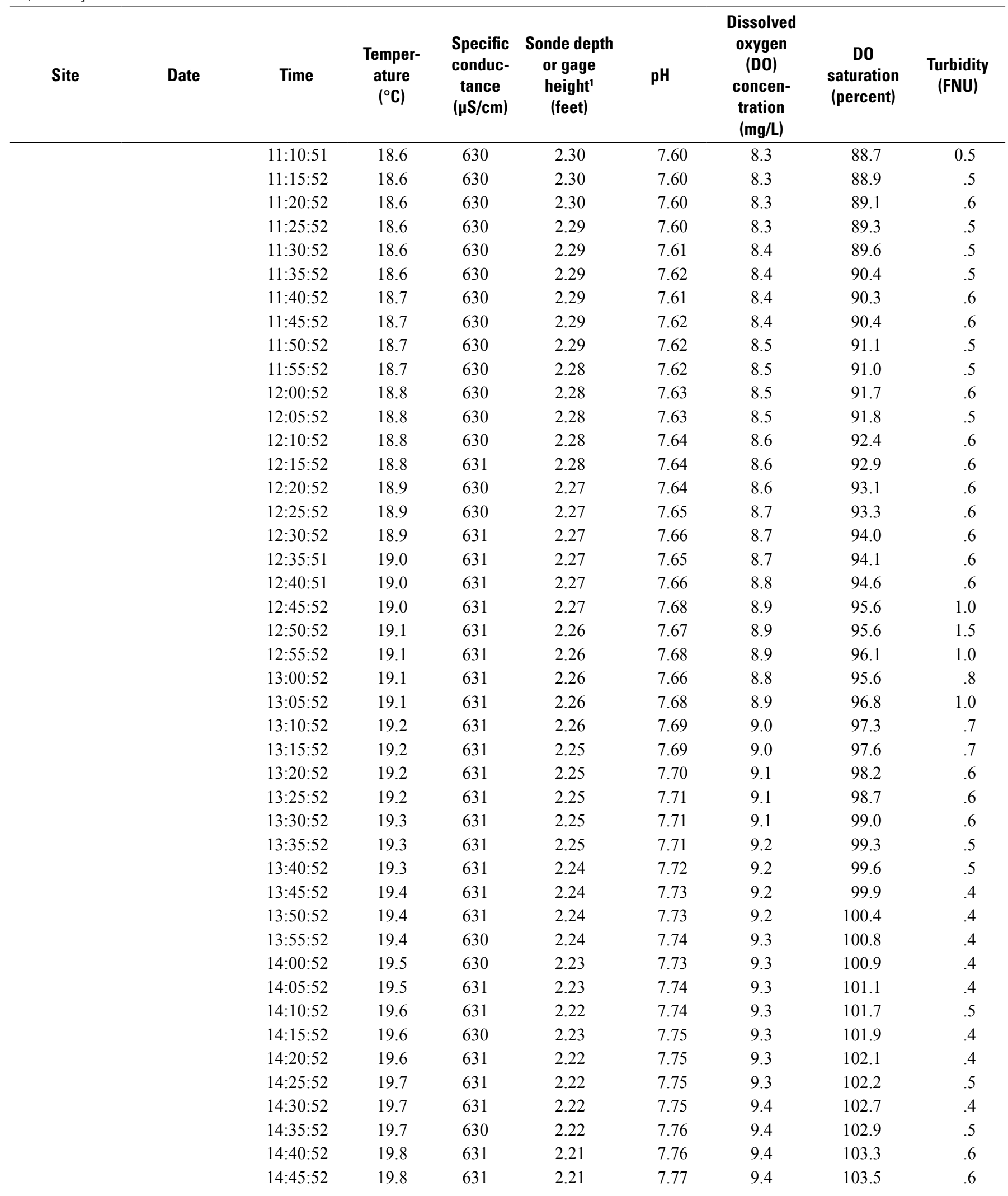


Table 1-2. Chemical and physical properties measured by water-quality monitors during the period of dye tracing in Tacony/ Frankford Creek, Philadelphia, Pa. on August 18, September 1, and September 3, 2009.-Continued

$\left[{ }^{\circ} \mathrm{C}\right.$, degrees Celsius; $\mu \mathrm{S} / \mathrm{cm}$, microsiemens per centimter; mg/L, milligrams per liter; FNU, Formazin Nephelometric units; USGS, U.S. Geological Survey; ,-- no data]

\begin{tabular}{|c|c|c|c|c|c|c|c|c|c|}
\hline Site & Date & Time & $\begin{array}{c}\text { Temper- } \\
\text { ature } \\
\left({ }^{\circ} \mathrm{C}\right)\end{array}$ & $\begin{array}{c}\text { Specific } \\
\text { conduc- } \\
\text { tance } \\
(\mu \mathrm{S} / \mathrm{cm})\end{array}$ & $\begin{array}{c}\text { Sonde depth } \\
\text { or gage } \\
\text { height }^{1} \\
\text { (feet) }\end{array}$ & $\mathbf{p H}$ & $\begin{array}{l}\text { Dissolved } \\
\text { oxygen } \\
\text { (DO) } \\
\text { concen- } \\
\text { tration } \\
\text { (mg/L) }\end{array}$ & $\begin{array}{c}\text { DO } \\
\text { saturation } \\
\text { (percent) }\end{array}$ & $\begin{array}{c}\text { Turbidity } \\
\text { (FNU) }\end{array}$ \\
\hline & & $14: 50: 52$ & 19.8 & 630 & 2.21 & 7.77 & 9.4 & 103.7 & 0.6 \\
\hline & & $14: 55: 52$ & 19.9 & 631 & 2.21 & 7.77 & 9.5 & 104.0 & .5 \\
\hline & & $15: 00: 52$ & 19.9 & 631 & 2.21 & 7.78 & 9.5 & 104.2 & .6 \\
\hline & & $15: 05: 52$ & 19.9 & 630 & 2.21 & 7.78 & 9.5 & 104.5 & .4 \\
\hline & & $15: 10: 52$ & 20.0 & 631 & 2.21 & 7.78 & 9.5 & 104.7 & .8 \\
\hline & & $15: 15: 52$ & 20.0 & 630 & 2.21 & 7.79 & 9.5 & 104.9 & .4 \\
\hline & & $15: 20: 52$ & 20.0 & 630 & 2.20 & 7.79 & 9.5 & 105.1 & .6 \\
\hline & & $15: 25: 52$ & 20.1 & 631 & 2.21 & 7.79 & 9.6 & 105.5 & .6 \\
\hline & & $15: 30: 52$ & 20.1 & 631 & 2.20 & 7.80 & 9.6 & 105.7 & .6 \\
\hline & & $15: 35: 52$ & 20.1 & 630 & 2.20 & 7.81 & 9.6 & 106.1 & .5 \\
\hline & & $15: 40: 52$ & 20.2 & 631 & 2.20 & 7.81 & 9.6 & 106.3 & .6 \\
\hline & & $15: 45: 52$ & 20.2 & 631 & 2.19 & 7.81 & 9.6 & 106.4 & .6 \\
\hline & & $15: 50: 52$ & 20.2 & 631 & 2.19 & 7.82 & 9.6 & 106.6 & .5 \\
\hline & & $15: 55: 52$ & 20.3 & 631 & 2.19 & 7.82 & 9.6 & 106.7 & .6 \\
\hline & & $16: 00: 52$ & 20.3 & 630 & 2.19 & 7.82 & 9.7 & 107.1 & .6 \\
\hline & & $16: 05: 52$ & 20.3 & 630 & 2.19 & 7.83 & 9.7 & 107.2 & .5 \\
\hline & & $16: 10: 52$ & 20.3 & 630 & 2.19 & 7.83 & 9.7 & 107.4 & .6 \\
\hline & & $16: 15: 52$ & 20.4 & 631 & 2.19 & 7.83 & 9.7 & 107.3 & .6 \\
\hline & & $16: 20: 52$ & 20.4 & 630 & 2.19 & 7.83 & 9.7 & 107.5 & .6 \\
\hline & & $16: 25: 51$ & 20.4 & 631 & 2.19 & 7.83 & 9.7 & 107.6 & .6 \\
\hline & & $16: 30: 52$ & 20.4 & 631 & 2.18 & 7.84 & 9.7 & 108.1 & .7 \\
\hline & & $16: 35: 52$ & 20.5 & 630 & 2.18 & 7.84 & 9.7 & 108.0 & .7 \\
\hline & & $16: 40: 52$ & 20.4 & 630 & 2.19 & 7.84 & 9.7 & 108.1 & .7 \\
\hline & & $16: 45: 52$ & 20.5 & 631 & 2.19 & 7.84 & 9.7 & 108.2 & .6 \\
\hline & & $16: 50: 52$ & 20.5 & 630 & 2.19 & 7.85 & 9.7 & 108.2 & .7 \\
\hline & & $16: 55: 52$ & 20.5 & 630 & 2.19 & 7.85 & 9.7 & 108.2 & .7 \\
\hline & & $17: 00: 52$ & 20.5 & 630 & 2.19 & 7.86 & 9.8 & 108.6 & .7 \\
\hline & & $17: 05: 52$ & 20.5 & 631 & 2.18 & 7.86 & 9.8 & 108.5 & .7 \\
\hline & & $17: 10: 52$ & 20.5 & 630 & 2.18 & 7.86 & 9.8 & 108.4 & .6 \\
\hline & & $17: 15: 52$ & 20.5 & 630 & 2.18 & 7.86 & 9.8 & 108.6 & .7 \\
\hline & & $17: 20: 52$ & 20.5 & 630 & 2.18 & 7.86 & 9.7 & 108.3 & .6 \\
\hline & & $17: 25: 52$ & 20.5 & 630 & 2.18 & 7.87 & 9.8 & 108.6 & .6 \\
\hline & & $17: 30: 52$ & 20.5 & 630 & 2.18 & 7.86 & 9.7 & 108.2 & .6 \\
\hline & & $17: 35: 52$ & 20.5 & 630 & 2.18 & 7.87 & 9.7 & 108.3 & .6 \\
\hline & & $17: 40: 52$ & 20.5 & 630 & 2.18 & 7.87 & 9.7 & 108.1 & .6 \\
\hline & & $17: 45: 52$ & 20.5 & 631 & 2.18 & 7.87 & 9.7 & 108.1 & .7 \\
\hline & & $17: 50: 52$ & 20.5 & 630 & 2.18 & 7.87 & 9.7 & 108.2 & .7 \\
\hline & & $17: 55: 52$ & 20.5 & 631 & 2.18 & 7.88 & 9.7 & 108.1 & .7 \\
\hline & & 18:00:52 & 20.5 & 630 & 2.18 & 7.87 & 9.7 & 107.7 & .6 \\
\hline & & $18: 05: 52$ & 20.5 & 630 & 2.18 & 7.87 & 9.7 & 107.7 & .6 \\
\hline & & $18: 10: 52$ & 20.5 & 630 & 2.18 & 7.87 & 9.7 & 107.5 & .8 \\
\hline & & $18: 15: 52$ & 20.5 & 631 & 2.18 & 7.87 & 9.7 & 107.4 & .8 \\
\hline & & $18: 20: 51$ & 20.5 & 630 & 2.18 & 7.87 & 9.6 & 107.3 & .6 \\
\hline & & $18: 25: 52$ & 20.5 & 630 & 2.18 & 7.87 & 9.6 & 107.1 & .6 \\
\hline
\end{tabular}


72 Determination of Time-of-Travel Characteristics and Reaeration Coefficients: Lower Tacony/Frankford Creek

Table 1-2. Chemical and physical properties measured by water-quality monitors during the period of dye tracing in Tacony/ Frankford Creek, Philadelphia, Pa. on August 18, September 1, and September 3, 2009.-Continued

$\left[{ }^{\circ} \mathrm{C}\right.$, degrees Celsius; $\mu \mathrm{S} / \mathrm{cm}$, microsiemens per centimter; mg/L, milligrams per liter; FNU, Formazin Nephelometric units; USGS, U.S. Geological Survey; --, no data]

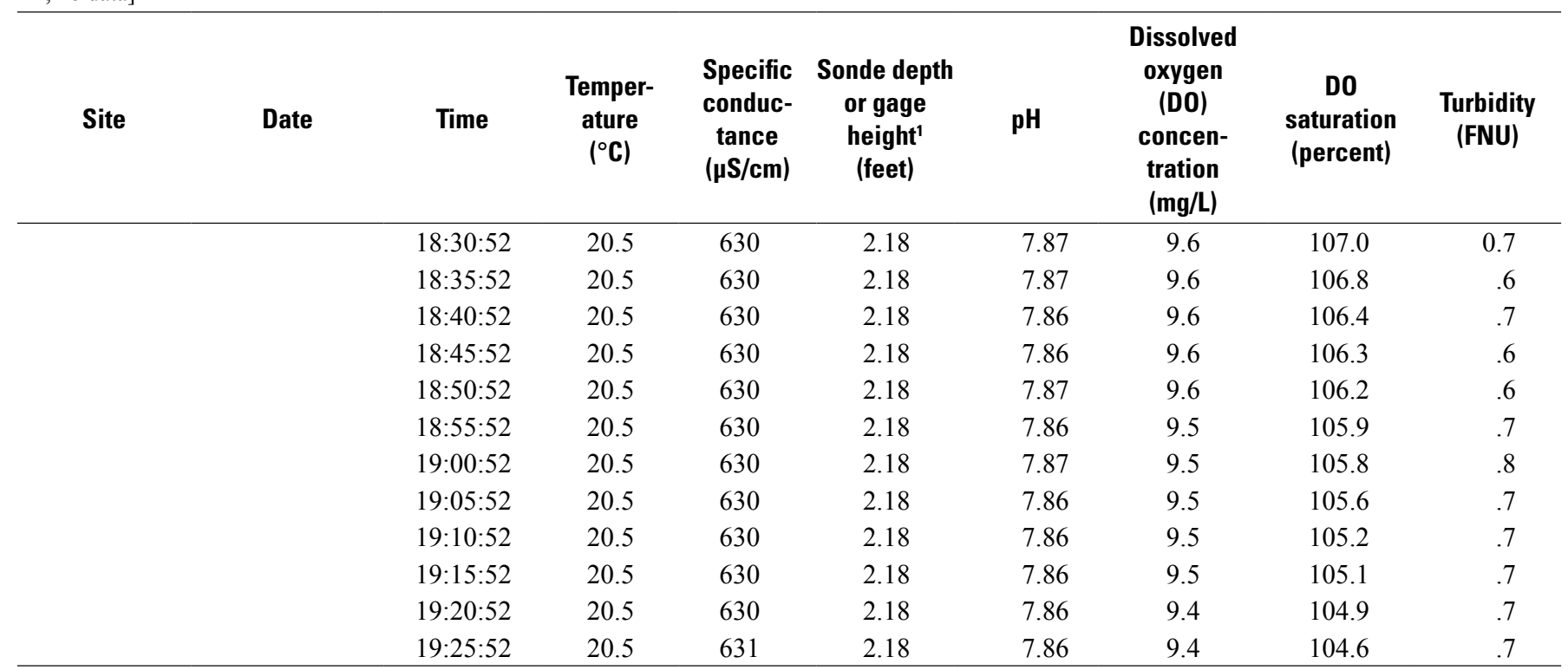

\footnotetext{
${ }^{1}$ Sonde depth was depth of water over water-quality sonde placed in stream at each site except for TACO250, where gage height is recorded as USGS streamgage 01467087.
} 


\section{Appendix 2.-Concentrations in Stream Samples}

Table 2-1. Dye concentrations measured in the laboratory for stream samples collected on August 18, September 1, and September 3, 2009, in Tacony/Frankford Creek, Philadelphia, Pa.

Table 2-2. Results of analyses for propane and methane gas in water samples collected on August 18, September 1, and September 3, 2009, Tacony/Frankford Creek, Philadelphia, 
Table 2-1. Dye concentrations measured in the laboratory for stream samples collected on August 18, September 1, and September 3, 2009, in Tacony/Frankford Creek, Philadelphia, Pa.

[USGS, U.S. Geological Survey; <, less than; --, no data]

\begin{tabular}{|c|c|c|c|c|c|c|}
\hline \multirow[t]{2}{*}{ Site } & \multirow{2}{*}{$\begin{array}{c}\text { USGS } \\
\text { site number }\end{array}$} & \multirow[t]{2}{*}{ Date } & \multirow[t]{2}{*}{ Time } & \multicolumn{3}{|c|}{$\begin{array}{c}\text { Dye concentration } \\
\text { (micrograms per liter) }\end{array}$} \\
\hline & & & & Right & Middle & Left \\
\hline \multirow[t]{33}{*}{ TACO275 } & 014670866 & $8 / 18 / 2009$ & $8: 05$ & $<0.01$ & $<0.01$ & $<0.01$ \\
\hline & & & $8: 55$ & $<.01$ & $<.01$ & $<.01$ \\
\hline & & & $9: 00$ & $<.01$ & $<.01$ & $<.01$ \\
\hline & & & $9: 05$ & $<.01$ & $<.01$ & $<.01$ \\
\hline & & & $9: 10$ & .10 & .06 & .01 \\
\hline & & & $9: 15$ & .65 & .30 & .30 \\
\hline & & & $9: 20$ & 1.97 & 1.61 & 1.09 \\
\hline & & & $9: 25$ & 4.76 & 4.21 & 2.07 \\
\hline & & & $9: 30$ & 7.24 & 6.47 & 4.71 \\
\hline & & & $9: 35$ & 11.7 & 10.4 & 5.29 \\
\hline & & & $9: 40$ & 13.3 & 12.9 & 10.7 \\
\hline & & & $9: 45$ & 13.9 & 14.0 & 9.54 \\
\hline & & & $9: 50$ & 14.9 & 15.0 & 14.6 \\
\hline & & & $9: 55$ & 14.2 & 14.7 & 11.3 \\
\hline & & & $10: 00$ & 14.2 & 14.1 & 13.0 \\
\hline & & & $10: 05$ & 12.7 & 13.7 & 12.5 \\
\hline & & & $10: 10$ & 12.4 & 12.6 & 12.9 \\
\hline & & & $10: 15$ & 11.7 & 11.8 & 11.3 \\
\hline & & & $10: 20$ & 11.0 & 11.1 & 11.2 \\
\hline & & & $10: 25$ & 10.9 & 10.0 & 10.1 \\
\hline & & & $10: 30$ & 8.93 & 9.33 & 9.77 \\
\hline & & & $10: 35$ & 9.41 & 8.34 & 8.84 \\
\hline & & & $10: 40$ & 7.28 & 7.72 & 8.43 \\
\hline & & & $10: 50$ & 7.74 & 6.41 & 6.41 \\
\hline & & & $11: 00$ & 5.31 & 5.35 & 5.84 \\
\hline & & & $11: 10$ & 5.43 & 4.39 & 4.66 \\
\hline & & & $11: 20$ & 3.63 & 3.86 & 3.98 \\
\hline & & & $11: 30$ & 3.08 & 2.98 & 3.44 \\
\hline & & & $11: 40$ & 2.31 & 2.56 & 3.11 \\
\hline & & & $12: 00$ & 1.54 & 2.09 & 1.77 \\
\hline & & & $12: 20$ & 1.14 & 1.11 & 1.26 \\
\hline & & & $12: 50$ & 1.03 & .62 & .69 \\
\hline & & & $13: 20$ & .38 & .34 & .37 \\
\hline
\end{tabular}


Table 2-1. Dye concentrations measured in the laboratory for stream samples collected on August 18, September 1, and September 3, 2009, in Tacony/Frankford Creek, Philadelphia, Pa.-Continued [USGS, U.S. Geological Survey; <, less than; --, no data]

\begin{tabular}{|c|c|c|c|c|c|c|}
\hline \multirow[t]{2}{*}{ Site } & \multirow{2}{*}{$\begin{array}{l}\text { USGS } \\
\text { site number }\end{array}$} & \multirow[t]{2}{*}{ Date } & \multirow[t]{2}{*}{ Time } & \multicolumn{3}{|c|}{$\begin{array}{c}\text { Dye concentration } \\
\text { (micrograms per liter) }\end{array}$} \\
\hline & & & & Right & Middle & Left \\
\hline \multirow[t]{40}{*}{ TACO269 } & 014670867 & $8 / 18 / 2009$ & $9: 30$ & $<0.01$ & $<0.01$ & $<0.01$ \\
\hline & & & $10: 00$ & $<.01$ & $<.01$ & $<.01$ \\
\hline & & & $10: 10$ & .15 & $<.01$ & $<.01$ \\
\hline & & & $10: 20$ & 1.24 & .03 & .04 \\
\hline & & & $10: 30$ & 2.13 & .04 & .48 \\
\hline & & & $10: 40$ & 2.27 & 1.77 & 2.11 \\
\hline & & & $10: 50$ & 5.24 & 1.90 & 3.55 \\
\hline & & & $11: 00$ & 4.90 & 4.50 & 4.72 \\
\hline & & & $11: 10$ & 5.70 & 4.25 & 3.80 \\
\hline & & & $11: 20$ & 4.44 & 3.50 & 4.75 \\
\hline & & & $11: 30$ & 5.62 & 4.96 & 3.00 \\
\hline & & & $11: 40$ & 1.84 & 2.91 & 4.2 \\
\hline & & & $11: 50$ & 1.55 & 3.83 & 4.97 \\
\hline & & & $12: 00$ & 5.40 & 3.27 & 4.16 \\
\hline & & & $12: 10$ & 4.36 & 3.07 & 3.90 \\
\hline & & & $12: 20$ & 3.58 & 3.46 & 4.00 \\
\hline & & & $12: 30$ & 2.31 & 3.58 & 3.77 \\
\hline & & & $12: 40$ & -- & 3.78 & 3.66 \\
\hline & & & $12: 50$ & 3.61 & 3.25 & 3.43 \\
\hline & & & $13: 00$ & -- & 3.50 & 3.3 \\
\hline & & & $13: 10$ & 3.73 & 3.37 & 3.21 \\
\hline & & & $13: 30$ & -- & 3.36 & 3.30 \\
\hline & & & $13: 31$ & 3.2 & 3.33 & 2.99 \\
\hline & & & $13: 50$ & -- & 3.14 & 2.99 \\
\hline & & & $14: 00$ & 2.15 & 2.57 & 2.35 \\
\hline & & & $14: 10$ & -- & 2.71 & 2.62 \\
\hline & & & $14: 30$ & 1.69 & 1.96 & 1.87 \\
\hline & & & $14: 31$ & -- & 1.18 & 1.15 \\
\hline & & & $14: 50$ & -- & 2.11 & 2.04 \\
\hline & & & $15: 00$ & 1.43 & 2.18 & 1.75 \\
\hline & & & $15: 10$ & -- & 1.90 & 1.81 \\
\hline & & & $15: 30$ & 1.03 & 1.49 & 1.31 \\
\hline & & & $16: 00$ & .98 & 1.38 & 1.06 \\
\hline & & & $16: 30$ & .82 & .97 & .94 \\
\hline & & & $17: 00$ & -- & 1.02 & 1.00 \\
\hline & & & $17: 28$ & .54 & .60 & .73 \\
\hline & & & $17: 30$ & -- & .81 & .80 \\
\hline & & & $18: 00$ & .39 & .68 & .67 \\
\hline & & & $18: 25$ & -- & .55 & .5 \\
\hline & & & $18: 30$ & -- & .52 & .53 \\
\hline
\end{tabular}


Table 2-1. Dye concentrations measured in the laboratory for stream samples collected on August 18, September 1, and September 3, 2009, in Tacony/Frankford Creek, Philadelphia, Pa.-Continued [USGS, U.S. Geological Survey; <, less than; --, no data]

\begin{tabular}{|c|c|c|c|c|c|c|}
\hline \multirow[t]{2}{*}{ Site } & \multirow{2}{*}{$\begin{array}{c}\text { USGS } \\
\text { site number }\end{array}$} & \multirow[t]{2}{*}{ Date } & \multirow[t]{2}{*}{ Time } & \multicolumn{3}{|c|}{$\begin{array}{c}\text { Dye concentration } \\
\text { (micrograms per liter) }\end{array}$} \\
\hline & & & & Right & Middle & Left \\
\hline \multirow[t]{34}{*}{ TACO263 } & 014670868 & $8 / 18 / 2009$ & $10: 10$ & $<0.01$ & $<0.01$ & $<0.01$ \\
\hline & & & $10: 20$ & $<.01$ & $<.01$ & $<.01$ \\
\hline & & & $10: 30$ & $<.01$ & $<.01$ & $<.01$ \\
\hline & & & $10: 40$ & .04 & .04 & .05 \\
\hline & & & $10: 50$ & .30 & .35 & .38 \\
\hline & & & $11: 00$ & .76 & .90 & 1.08 \\
\hline & & & $11: 10$ & 1.64 & 1.83 & 2.10 \\
\hline & & & $11: 20$ & 2.81 & 2.93 & 3.35 \\
\hline & & & $11: 30$ & 3.40 & 3.61 & 3.80 \\
\hline & & & $11: 40$ & 3.84 & 3.96 & 4.12 \\
\hline & & & $11: 50$ & 4.00 & 4.07 & 4.32 \\
\hline & & & $12: 00$ & 4.10 & 4.10 & 4.32 \\
\hline & & & $12: 10$ & 4.05 & 4.17 & 4.05 \\
\hline & & & $12: 20$ & 3.95 & 3.96 & 4.01 \\
\hline & & & $12: 30$ & 3.8 & 3.73 & 3.68 \\
\hline & & & $12: 40$ & 3.84 & 3.78 & 3.66 \\
\hline & & & $12: 50$ & 3.67 & 3.68 & 3.55 \\
\hline & & & $13: 00$ & 3.61 & 3.50 & 3.30 \\
\hline & & & $13: 10$ & 3.42 & 3.45 & 3.34 \\
\hline & & & $13: 30$ & 3.47 & 3.36 & 3.30 \\
\hline & & & $13: 50$ & 3.24 & 3.14 & 2.99 \\
\hline & & & $14: 10$ & 2.84 & 2.71 & 2.62 \\
\hline & & & $14: 30$ & 2.53 & 2.45 & 2.34 \\
\hline & & & $14: 31$ & 1.21 & 1.18 & 1.15 \\
\hline & & & $14: 50$ & 2.08 & 2.11 & 2.04 \\
\hline & & & $15: 10$ & 1.90 & 1.90 & 1.81 \\
\hline & & & $15: 30$ & 1.72 & 1.71 & 1.64 \\
\hline & & & $16: 00$ & 1.40 & 1.37 & 1.36 \\
\hline & & & $16: 30$ & 1.20 & 2.58 & 1.20 \\
\hline & & & $16: 50$ & 1.10 & 2.08 & 1.10 \\
\hline & & & $17: 00$ & 1.03 & 1.02 & 1.00 \\
\hline & & & $17: 30$ & .82 & .81 & .80 \\
\hline & & & $18: 00$ & .68 & .68 & .67 \\
\hline & & & $18: 30$ & .55 & .52 & .53 \\
\hline
\end{tabular}


Table 2-1. Dye concentrations measured in the laboratory for stream samples collected on August 18, September 1, and September 3, 2009, in Tacony/Frankford Creek, Philadelphia, Pa.-Continued [USGS, U.S. Geological Survey; <, less than; --, no data]

\begin{tabular}{|c|c|c|c|c|c|c|}
\hline \multirow[t]{2}{*}{ Site } & \multirow{2}{*}{$\begin{array}{c}\text { USGS } \\
\text { site number }\end{array}$} & \multirow[t]{2}{*}{ Date } & \multirow[t]{2}{*}{ Time } & \multicolumn{3}{|c|}{$\begin{array}{c}\text { Dye concentration } \\
\text { (micrograms per liter) }\end{array}$} \\
\hline & & & & Right & Middle & Left \\
\hline \multirow{32}{*}{ TACO260 } & 014670869 & $8 / 18 / 2009$ & $8: 43$ & -- & $<0.01$ & -- \\
\hline & & & $11: 50$ & -- & $<.01$ & -- \\
\hline & & & $12: 00$ & -- & $<.01$ & -- \\
\hline & & & $12: 10$ & -- & $<.01$ & -- \\
\hline & & & $12: 20$ & -- & $<.01$ & -- \\
\hline & & & $12: 30$ & -- & $<.01$ & -- \\
\hline & & & $12: 40$ & -- & $<.01$ & -- \\
\hline & & & $12: 50$ & -- & $<.01$ & -- \\
\hline & & & $13: 00$ & -- & .02 & -- \\
\hline & & & $13: 10$ & -- & .01 & -- \\
\hline & & & $13: 20$ & -- & .04 & -- \\
\hline & & & $13: 30$ & -- & .01 & -- \\
\hline & & & $13: 40$ & -- & .19 & -- \\
\hline & & & $13: 50$ & -- & .12 & -- \\
\hline & & & $14: 00$ & -- & .61 & -- \\
\hline & & & $14: 10$ & -- & .23 & -- \\
\hline & & & $14: 20$ & -- & .31 & -- \\
\hline & & & $14: 30$ & -- & .46 & -- \\
\hline & & & $14: 40$ & -- & .90 & -- \\
\hline & & & $14: 50$ & -- & .86 & -- \\
\hline & & & $15: 00$ & -- & .48 & -- \\
\hline & & & $15: 10$ & -- & 2.12 & -- \\
\hline & & & $15: 30$ & -- & 1.78 & -- \\
\hline & & & $15: 50$ & -- & 2.19 & -- \\
\hline & & & $16: 10$ & -- & 2.31 & -- \\
\hline & & & $17: 10$ & -- & 2.65 & -- \\
\hline & & & $17: 30$ & -- & 2.28 & -- \\
\hline & & & $17: 50$ & -- & 2.34 & -- \\
\hline & & & $18: 10$ & -- & 2.17 & -- \\
\hline & & & $18: 30$ & -- & 2.02 & -- \\
\hline & & & $18: 50$ & -- & 1.93 & -- \\
\hline & & & $19: 30$ & -- & 1.69 & -- \\
\hline
\end{tabular}


Table 2-1. Dye concentrations measured in the laboratory for stream samples collected on August 18, September 1, and September 3, 2009, in Tacony/Frankford Creek, Philadelphia, Pa._Continued [USGS, U.S. Geological Survey; <, less than; --, no data]

\begin{tabular}{|c|c|c|c|c|c|c|}
\hline \multirow[t]{2}{*}{ Site } & \multirow{2}{*}{$\begin{array}{c}\text { USGS } \\
\text { site number }\end{array}$} & \multirow[t]{2}{*}{ Date } & \multirow[t]{2}{*}{ Time } & \multicolumn{3}{|c|}{$\begin{array}{c}\text { Dye concentration } \\
\text { (micrograms per liter) }\end{array}$} \\
\hline & & & & Right & Middle & Left \\
\hline \multirow[t]{23}{*}{ TACO250 } & 01467087 & $8 / 18 / 2009$ & $8: 00$ & -- & $<0.01$ & -- \\
\hline & & & 9:00 & -- & $<.01$ & -- \\
\hline & & & $9: 22$ & -- & $<.01$ & -- \\
\hline & & & $12: 50$ & -- & $<.01$ & -- \\
\hline & & & $13: 00$ & -- & $<.01$ & -- \\
\hline & & & $13: 20$ & -- & $<.01$ & -- \\
\hline & & & $13: 40$ & -- & .02 & -- \\
\hline & & & $14: 00$ & -- & .07 & -- \\
\hline & & & $14: 20$ & -- & .23 & -- \\
\hline & & & $14: 40$ & -- & .37 & -- \\
\hline & & & $15: 00$ & -- & .60 & -- \\
\hline & & & $15: 20$ & -- & .87 & -- \\
\hline & & & $15: 40$ & -- & 1.16 & -- \\
\hline & & & $16: 00$ & -- & 1.57 & -- \\
\hline & & & $16: 20$ & -- & 1.77 & -- \\
\hline & & & $16: 40$ & -- & 2.03 & -- \\
\hline & & & $17: 00$ & -- & 2.00 & -- \\
\hline & & & $17: 30$ & -- & 2.05 & -- \\
\hline & & & $18: 00$ & -- & 2.10 & -- \\
\hline & & & $18: 38$ & -- & 2.08 & -- \\
\hline & & & 19:00 & -- & 2.02 & -- \\
\hline & & & $19: 30$ & -- & 1.94 & -- \\
\hline & & & $20: 00$ & -- & 1.83 & -- \\
\hline
\end{tabular}


Table 2-1. Dye concentrations measured in the laboratory for stream samples collected on August 18, September 1, and September 3, 2009, in Tacony/Frankford Creek, Philadelphia, Pa.-Continued

[USGS, U.S. Geological Survey; <, less than; --, no data]

\begin{tabular}{|c|c|c|c|c|c|c|}
\hline \multirow[t]{2}{*}{ Site } & \multirow{2}{*}{$\begin{array}{c}\text { USGS } \\
\text { site number }\end{array}$} & \multirow[t]{2}{*}{ Date } & \multirow[t]{2}{*}{ Time } & \multicolumn{3}{|c|}{$\begin{array}{c}\text { Dye concentration } \\
\text { (micrograms per liter) }\end{array}$} \\
\hline & & & & Right & Middle & Left \\
\hline \multirow[t]{30}{*}{ TACO263 } & 014670868 & $9 / 1 / 2009$ & $7: 30$ & $<0.01$ & $<0.01$ & $<0.01$ \\
\hline & & & $7: 40$ & $<.01$ & $<.01$ & $<.01$ \\
\hline & & & $7: 42$ & .01 & .02 & .03 \\
\hline & & & $7: 44$ & .01 & .01 & .01 \\
\hline & & & $7: 46$ & .01 & .01 & .02 \\
\hline & & & $7: 48$ & .01 & $<.01$ & .01 \\
\hline & & & $7: 50$ & .01 & .01 & .01 \\
\hline & & & $7: 52$ & .14 & .15 & .10 \\
\hline & & & $7: 54$ & 4.12 & 11.5 & 11.5 \\
\hline & & & $7: 56$ & 15.4 & 38.4 & 47.0 \\
\hline & & & $7: 58$ & 48.1 & 51.8 & 69.5 \\
\hline & & & $8: 00$ & 38.8 & 44.9 & 57.5 \\
\hline & & & 8:02 & 30.5 & 31.3 & 41.5 \\
\hline & & & 8:04 & 23.0 & 21.0 & 25.5 \\
\hline & & & $8: 06$ & 17.9 & 16.5 & 16.6 \\
\hline & & & 8:08 & 17.1 & 13.9 & 13.0 \\
\hline & & & $8: 10$ & 14.6 & 11.5 & 9.70 \\
\hline & & & $8: 12$ & 12.2 & 9.39 & 7.94 \\
\hline & & & $8: 15$ & 10.8 & 6.91 & 7.45 \\
\hline & & & $8: 20$ & 9.93 & 5.53 & 5.93 \\
\hline & & & $8: 25$ & 7.48 & 4.53 & 2.92 \\
\hline & & & $8: 30$ & 5.34 & 3.44 & 2.65 \\
\hline & & & $8: 40$ & 3.00 & 2.26 & 1.59 \\
\hline & & & $8: 50$ & 2.35 & 1.35 & .84 \\
\hline & & & 9:00 & 1.27 & .84 & .48 \\
\hline & & & $9: 10$ & .85 & .56 & .38 \\
\hline & & & $9: 30$ & .37 & .21 & .16 \\
\hline & & & 10:00 & .17 & .13 & .06 \\
\hline & & & $11: 00$ & .04 & .02 & .03 \\
\hline & & & $12: 00$ & -- & .01 & .04 \\
\hline
\end{tabular}


Table 2-1. Dye concentrations measured in the laboratory for stream samples collected on August 18, September 1, and September 3, 2009, in Tacony/Frankford Creek, Philadelphia, Pa._Continued [USGS, U.S. Geological Survey; <, less than; --, no data]

\begin{tabular}{|c|c|c|c|c|c|c|}
\hline \multirow[t]{2}{*}{ Site } & \multirow{2}{*}{$\begin{array}{c}\text { USGS } \\
\text { site number }\end{array}$} & \multirow[t]{2}{*}{ Date } & \multirow[t]{2}{*}{ Time } & \multicolumn{3}{|c|}{$\begin{array}{c}\text { Dye concentration } \\
\text { (micrograms per liter) }\end{array}$} \\
\hline & & & & Right & Middle & Left \\
\hline \multirow[t]{37}{*}{ TACO260 } & 014670869 & $9 / 1 / 2009$ & $8: 16$ & -- & $<0.01$ & -- \\
\hline & & & $8: 20$ & -- & $<.01$ & -- \\
\hline & & & $8: 30$ & -- & $<.01$ & -- \\
\hline & & & $8: 40$ & -- & $<.01$ & -- \\
\hline & & & $8: 50$ & -- & $<.01$ & -- \\
\hline & & & 9:00 & -- & $<.01$ & -- \\
\hline & & & $9: 10$ & -- & $<.01$ & -- \\
\hline & & & $9: 20$ & -- & $<.01$ & -- \\
\hline & & & $9: 30$ & -- & $<.01$ & -- \\
\hline & & & $9: 40$ & -- & $<.01$ & -- \\
\hline & & & $9: 50$ & -- & $<.01$ & -- \\
\hline & & & $10: 00$ & -- & $<.01$ & -- \\
\hline & & & $10: 10$ & -- & .03 & -- \\
\hline & & & $10: 20$ & -- & .08 & -- \\
\hline & & & $10: 30$ & -- & .69 & -- \\
\hline & & & $10: 40$ & -- & 1.41 & -- \\
\hline & & & $10: 50$ & -- & 3.21 & -- \\
\hline & & & $11: 00$ & -- & 4.16 & -- \\
\hline & & & $11: 10$ & -- & 4.89 & -- \\
\hline & & & $11: 20$ & -- & 4.89 & -- \\
\hline & & & $11: 30$ & -- & 5.23 & -- \\
\hline & & & $11: 40$ & -- & 5.23 & -- \\
\hline & & & $11: 50$ & -- & 5.12 & -- \\
\hline & & & $12: 00$ & -- & 4.80 & -- \\
\hline & & & $12: 10$ & -- & 3.98 & -- \\
\hline & & & $12: 20$ & -- & 3.20 & -- \\
\hline & & & $12: 30$ & -- & 3.26 & -- \\
\hline & & & $12: 40$ & -- & 2.92 & -- \\
\hline & & & $13: 00$ & -- & 1.83 & -- \\
\hline & & & $13: 20$ & -- & 1.23 & -- \\
\hline & & & $13: 40$ & -- & 1.24 & -- \\
\hline & & & $14: 00$ & -- & .90 & -- \\
\hline & & & $14: 20$ & -- & .79 & -- \\
\hline & & & $14: 40$ & -- & .65 & -- \\
\hline & & & $15: 30$ & -- & .41 & -- \\
\hline & & & $16: 00$ & -- & .21 & -- \\
\hline & & & $17: 00$ & -- & .12 & -- \\
\hline
\end{tabular}


Table 2-1. Dye concentrations measured in the laboratory for stream samples collected on August 18, September 1, and September 3, 2009, in Tacony/Frankford Creek, Philadelphia, Pa.-Continued

[USGS, U.S. Geological Survey; <, less than; --, no data]

\begin{tabular}{|c|c|c|c|c|c|c|}
\hline \multirow[t]{2}{*}{ Site } & \multirow{2}{*}{$\begin{array}{c}\text { USGS } \\
\text { site number }\end{array}$} & \multirow[t]{2}{*}{ Date } & \multirow[t]{2}{*}{ Time } & \multicolumn{3}{|c|}{$\begin{array}{c}\text { Dye concentration } \\
\text { (micrograms per liter) }\end{array}$} \\
\hline & & & & Right & Middle & Left \\
\hline \multirow[t]{41}{*}{ TACO 250} & 01467087 & $9 / 1 / 2009$ & $8: 05$ & -- & $<0.01$ & -- \\
\hline & & & $10: 30$ & -- & $<.01$ & -- \\
\hline & & & $10: 40$ & -- & $<.01$ & -- \\
\hline & & & $10: 50$ & -- & $<.01$ & -- \\
\hline & & & $11: 00$ & -- & .01 & -- \\
\hline & & & $11: 10$ & -- & .23 & -- \\
\hline & & & $11: 20$ & -- & .59 & -- \\
\hline & & & $11: 30$ & -- & 1.62 & -- \\
\hline & & & $11: 40$ & -- & 2.28 & -- \\
\hline & & & $11: 50$ & -- & 2.99 & -- \\
\hline & & & $12: 00$ & -- & 3.51 & -- \\
\hline & & & $12: 10$ & -- & 4.07 & -- \\
\hline & & & $12: 20$ & -- & 4.35 & -- \\
\hline & & & $12: 30$ & -- & 4.17 & -- \\
\hline & & & $12: 40$ & -- & 4.21 & -- \\
\hline & & & $12: 50$ & -- & 4.02 & -- \\
\hline & & & $13: 00$ & -- & 3.78 & -- \\
\hline & & & $13: 10$ & -- & 3.37 & -- \\
\hline & & & $13: 20$ & -- & 3.21 & -- \\
\hline & & & $13: 30$ & -- & 2.84 & -- \\
\hline & & & $13: 40$ & -- & 2.66 & -- \\
\hline & & & $13: 50$ & -- & 2.47 & -- \\
\hline & & & $14: 00$ & -- & 2.18 & -- \\
\hline & & & $14: 10$ & -- & 1.96 & -- \\
\hline & & & $14: 20$ & -- & 1.67 & -- \\
\hline & & & $14: 30$ & -- & 1.58 & -- \\
\hline & & & $14: 40$ & -- & 1.33 & -- \\
\hline & & & $14: 50$ & -- & 1.24 & -- \\
\hline & & & $15: 00$ & -- & 1.15 & -- \\
\hline & & & $15: 10$ & -- & .38 & -- \\
\hline & & & $15: 20$ & -- & .92 & -- \\
\hline & & & $15: 40$ & -- & .65 & -- \\
\hline & & & $16: 00$ & -- & .53 & -- \\
\hline & & & $16: 20$ & -- & .42 & -- \\
\hline & & & $16: 40$ & -- & .39 & -- \\
\hline & & & $17: 00$ & -- & .25 & -- \\
\hline & & & $17: 20$ & -- & .21 & -- \\
\hline & & & $17: 40$ & -- & .15 & -- \\
\hline & & & $18: 00$ & -- & .13 & -- \\
\hline & & & $18: 20$ & -- & .11 & -- \\
\hline & & & $18: 40$ & -- & .11 & -- \\
\hline
\end{tabular}


Table 2-1. Dye concentrations measured in the laboratory for stream samples collected on August 18, September 1, and September 3, 2009, in Tacony/Frankford Creek, Philadelphia, Pa._Continued [USGS, U.S. Geological Survey; <, less than; --, no data]

\begin{tabular}{|c|c|c|c|c|c|c|}
\hline \multirow[t]{2}{*}{ Site } & \multirow{2}{*}{$\begin{array}{c}\text { USGS } \\
\text { site number }\end{array}$} & \multirow[t]{2}{*}{ Date } & \multirow[t]{2}{*}{ Time } & \multicolumn{3}{|c|}{$\begin{array}{c}\text { Dye concentration } \\
\text { (micrograms per liter) }\end{array}$} \\
\hline & & & & Right & Middle & Left \\
\hline \multirow[t]{26}{*}{ TACO315 } & 014670864 & $9 / 3 / 2009$ & $7: 15$ & $<0.01$ & $<0.01$ & $<0.01$ \\
\hline & & & $7: 20$ & $<.01$ & $<.01$ & $<.01$ \\
\hline & & & $7: 25$ & $<.01$ & $<.01$ & $<.01$ \\
\hline & & & $7: 30$ & 7.90 & 7.15 & 2.69 \\
\hline & & & $7: 35$ & 46.2 & 41.9 & 26.5 \\
\hline & & & $7: 40$ & 62.9 & 56.6 & 47.3 \\
\hline & & & $7: 45$ & 51.6 & 52.0 & 51.7 \\
\hline & & & $7: 50$ & 40.6 & 39.9 & 41.7 \\
\hline & & & $7: 55$ & 30.9 & 31.6 & 35.9 \\
\hline & & & $8: 00$ & 24.2 & 25.4 & 27.4 \\
\hline & & & $8: 05$ & 19.0 & 19.6 & 21.2 \\
\hline & & & $8: 10$ & 14.6 & 15.4 & 16.8 \\
\hline & & & $8: 15$ & 12.1 & 12.1 & 12.9 \\
\hline & & & $8: 20$ & 8.77 & 9.45 & 11.0 \\
\hline & & & $8: 25$ & 7.29 & 7.45 & 8.77 \\
\hline & & & $8: 30$ & 5.88 & 5.90 & 7.06 \\
\hline & & & $8: 40$ & 4.20 & 4.54 & 5.74 \\
\hline & & & $8: 50$ & 3.05 & 3.65 & 4.38 \\
\hline & & & 9:00 & 2.27 & 2.47 & 2.99 \\
\hline & & & $9: 20$ & 1.21 & 1.47 & 2.08 \\
\hline & & & $9: 40$ & .78 & .96 & 1.32 \\
\hline & & & $10: 00$ & .54 & .64 & .94 \\
\hline & & & $10: 30$ & .35 & .40 & .42 \\
\hline & & & $11: 00$ & .15 & .21 & .42 \\
\hline & & & $11: 30$ & .13 & .15 & .22 \\
\hline & & & $12: 00$ & .10 & .13 & .14 \\
\hline
\end{tabular}


Table 2-1. Dye concentrations measured in the laboratory for stream samples collected on August 18, September 1, and September 3, 2009, in Tacony/Frankford Creek, Philadelphia, Pa.-Continued

[USGS, U.S. Geological Survey; <, less than; --, no data]

\begin{tabular}{|c|c|c|c|c|c|c|}
\hline \multirow[t]{2}{*}{ Site } & \multirow{2}{*}{$\begin{array}{c}\text { USGS } \\
\text { site number }\end{array}$} & \multirow[t]{2}{*}{ Date } & \multirow[t]{2}{*}{ Time } & \multicolumn{3}{|c|}{$\begin{array}{c}\text { Dye concentration } \\
\text { (micrograms per liter) }\end{array}$} \\
\hline & & & & Right & Middle & Left \\
\hline \multirow[t]{40}{*}{ TACO285 } & 014670865 & $9 / 3 / 2009$ & $9: 40$ & $<0.01$ & $<0.01$ & $<0.01$ \\
\hline & & & $9: 50$ & $<.01$ & $<.01$ & $<.01$ \\
\hline & & & $10: 00$ & $<.01$ & $<.01$ & $<.01$ \\
\hline & & & $10: 10$ & .02 & .01 & $<.01$ \\
\hline & & & $10: 20$ & -- & .11 & -- \\
\hline & & & $10: 30$ & .59 & .68 & .57 \\
\hline & & & $10: 40$ & -- & 1.86 & -- \\
\hline & & & $10: 50$ & 3.80 & 3.57 & 3.46 \\
\hline & & & $11: 00$ & -- & 5.08 & -- \\
\hline & & & $11: 10$ & 8.20 & 7.30 & 6.52 \\
\hline & & & $11: 20$ & -- & 8.07 & -- \\
\hline & & & $11: 30$ & 10.8 & 9.83 & 9.21 \\
\hline & & & $11: 40$ & -- & 10.5 & -- \\
\hline & & & $11: 50$ & 11.3 & 10.1 & 10.5 \\
\hline & & & $12: 00$ & -- & 10.2 & -- \\
\hline & & & $12: 10$ & 11.2 & 9.76 & 9.49 \\
\hline & & & $12: 20$ & -- & 9.54 & -- \\
\hline & & & $12: 30$ & 9.50 & 8.43 & 9.08 \\
\hline & & & $12: 40$ & -- & 7.90 & -- \\
\hline & & & $12: 50$ & 7.64 & 7.05 & 7.44 \\
\hline & & & $13: 00$ & -- & 6.69 & -- \\
\hline & & & $13: 10$ & 6.27 & 6.07 & 6.00 \\
\hline & & & $13: 20$ & -- & 4.98 & -- \\
\hline & & & $13: 30$ & 4.64 & 4.30 & 4.41 \\
\hline & & & $13: 40$ & -- & 3.76 & -- \\
\hline & & & $13: 50$ & 3.72 & 3.33 & 3.50 \\
\hline & & & $14: 00$ & -- & 3.08 & -- \\
\hline & & & $14: 10$ & 2.79 & 2.52 & 2.48 \\
\hline & & & $14: 20$ & -- & 2.39 & -- \\
\hline & & & $14: 30$ & 2.10 & 2.02 & 2.08 \\
\hline & & & $14: 50$ & 1.66 & 1.65 & 1.62 \\
\hline & & & $15: 10$ & 1.34 & 1.14 & 1.14 \\
\hline & & & $15: 30$ & 1.09 & .93 & .92 \\
\hline & & & $15: 50$ & .87 & .80 & .88 \\
\hline & & & $16: 10$ & -- & .67 & -- \\
\hline & & & $16: 30$ & -- & .64 & -- \\
\hline & & & $16: 50$ & -- & .48 & -- \\
\hline & & & $17: 10$ & -- & .38 & -- \\
\hline & & & $17: 30$ & -- & .37 & -- \\
\hline & & & $17: 50$ & -- & .33 & -- \\
\hline
\end{tabular}


Table 2-1. Dye concentrations measured in the laboratory for stream samples collected on August 18, September 1, and September 3, 2009, in Tacony/Frankford Creek, Philadelphia, Pa._Continued [USGS, U.S. Geological Survey; <, less than; --, no data]

\begin{tabular}{|c|c|c|c|c|c|c|}
\hline \multirow[t]{2}{*}{ Site } & \multirow{2}{*}{$\begin{array}{c}\text { USGS } \\
\text { site number }\end{array}$} & \multirow[t]{2}{*}{ Date } & \multirow[t]{2}{*}{ Time } & \multicolumn{3}{|c|}{$\begin{array}{c}\text { Dye concentration } \\
\text { (micrograms per liter) }\end{array}$} \\
\hline & & & & Right & Middle & Left \\
\hline \multirow[t]{44}{*}{ TACO 275} & 014670866 & $9 / 3 / 2009$ & $10: 30$ & -- & $<0.01$ & -- \\
\hline & & & $10: 40$ & -- & $<.01$ & -- \\
\hline & & & $10: 50$ & -- & $<.01$ & -- \\
\hline & & & $11: 00$ & -- & $<.01$ & -- \\
\hline & & & $11: 10$ & -- & $<.01$ & -- \\
\hline & & & $11: 20$ & -- & $<.01$ & -- \\
\hline & & & $11: 30$ & -- & $<.01$ & -- \\
\hline & & & $11: 40$ & -- & $<.01$ & -- \\
\hline & & & $11: 50$ & -- & $<.01$ & -- \\
\hline & & & $12: 00$ & -- & $<.01$ & -- \\
\hline & & & $12: 10$ & -- & .01 & -- \\
\hline & & & $12: 20$ & -- & .01 & -- \\
\hline & & & $12: 30$ & -- & .03 & -- \\
\hline & & & $12: 40$ & -- & .10 & -- \\
\hline & & & $12: 50$ & -- & .21 & -- \\
\hline & & & $13: 00$ & -- & .42 & -- \\
\hline & & & $13: 10$ & -- & 1.08 & -- \\
\hline & & & $13: 20$ & -- & 1.65 & -- \\
\hline & & & $13: 30$ & -- & 2.79 & -- \\
\hline & & & $13: 40$ & -- & 3.79 & -- \\
\hline & & & $13: 50$ & -- & 4.83 & -- \\
\hline & & & $14: 00$ & -- & 6.03 & -- \\
\hline & & & $14: 10$ & -- & 6.66 & -- \\
\hline & & & $14: 20$ & -- & 7.54 & -- \\
\hline & & & $14: 30$ & -- & 7.36 & -- \\
\hline & & & $14: 40$ & -- & 8.01 & -- \\
\hline & & & $14: 51$ & -- & 7.89 & -- \\
\hline & & & $15: 00$ & -- & 8.07 & -- \\
\hline & & & $15: 10$ & -- & 7.89 & -- \\
\hline & & & $15: 20$ & -- & 7.67 & -- \\
\hline & & & $15: 30$ & -- & 7.35 & -- \\
\hline & & & $15: 40$ & -- & 6.75 & -- \\
\hline & & & $15: 50$ & -- & 6.32 & -- \\
\hline & & & $16: 10$ & -- & 5.25 & -- \\
\hline & & & $16: 30$ & -- & 4.36 & -- \\
\hline & & & $16: 50$ & -- & 3.39 & -- \\
\hline & & & $17: 10$ & -- & 2.73 & -- \\
\hline & & & $17: 30$ & -- & 2.25 & -- \\
\hline & & & $17: 50$ & -- & 1.69 & -- \\
\hline & & & $18: 14$ & -- & 1.38 & -- \\
\hline & & & $18: 29$ & -- & 1.15 & -- \\
\hline & & & $18: 59$ & -- & .91 & -- \\
\hline & & & $19: 14$ & -- & .81 & -- \\
\hline & & & $19: 29$ & -- & .69 & -- \\
\hline
\end{tabular}


Table 2-2. Results of analyses for propane and methane gas in water samples collected on August 18, September 1, and September 3, 2009, Tacony/Frankford Creek, Philadelphia, Pa.

$[\mu \mathrm{g} / \mathrm{L}$, micrograms per liter; ND, not detected]

\begin{tabular}{|c|c|c|c|c|c|}
\hline Site and sample location & $\begin{array}{c}\text { Date and time } \\
\text { sample collected }\end{array}$ & $\begin{array}{c}\text { Laboratory } \\
\text { sample } \\
\text { dilution }\end{array}$ & $\begin{array}{l}\text { Propane } \\
\text { ( } \mu \mathrm{g} / \mathrm{L})\end{array}$ & $\begin{array}{c}\text { Methane } \\
(\mu \mathrm{g} / \mathrm{L})\end{array}$ & $\begin{array}{l}\text { Sample } \\
\text { remarks }\end{array}$ \\
\hline 014670866 TAC0275L & 8/18/09 18:04 & 3 & 80.7 & 29.0 & \\
\hline 014670866 TAC0275L & 8/18/09 18:48 & 3 & 86.4 & 31.7 & \\
\hline 014670866 TAC0275L & $8 / 18 / 09$ 19:31 & 3 & 85.8 & 32.5 & \\
\hline 014670866 TAC0275M & $8 / 18 / 09$ 17:54 & 3 & 84.2 & 28.6 & \\
\hline 014670866 TAC0275M & 8/18/09 19:10 & 3 & 84.2 & 29.8 & \\
\hline 014670866 TAC0275M & 8/18/09 19:30 & 3 & 85.2 & 29.2 & \\
\hline 014670866 TAC0275M & 8/18/09 19:45 & 3 & 81.4 & 27.4 & \\
\hline 014670866 TAC0275R & 8/18/09 18:12 & 3 & 85.2 & 25.2 & \\
\hline 014670866 TAC0275R & $8 / 18 / 0918: 58$ & 3 & 85.6 & 24.9 & \\
\hline 014670867 TAC0269L & 8/18/09 19:18 & 3 & 80.4 & 53.3 & \\
\hline 014670867 TAC0269L & $8 / 18 / 09$ 19:35 & 3 & 79.2 & 49.4 & \\
\hline 014670867 TAC0269L & 8/18/09 19:53 & 3 & 78.6 & 47.9 & \\
\hline 014670867 TAC0269M & $8 / 18 / 0918: 38$ & 3 & 75.0 & 38.4 & \\
\hline 014670867 TAC0269M & 8/18/09 19:12 & 3 & 78.4 & 46.0 & \\
\hline 014670867 TAC0269M & 8/18/09 19:50 & 3 & 81.4 & 44.1 & \\
\hline 014670867 TAC0269R & 8/18/09 18:30 & 3 & 69.7 & 41.0 & \\
\hline 014670867 TAC0269R & 8/18/09 18:52 & 3 & 80.8 & 48.1 & \\
\hline 014670867 TAC0269R & 8/18/09 19:08 & 3 & 81.0 & 49.5 & \\
\hline 014670867 TAC0269R & $8 / 18 / 0919: 25$ & 3 & 81.6 & 49.2 & \\
\hline 014670868 TACO263M & 8/18/09 19:24 & 1 & 43.3 & 22.5 & air bubble in 2 of 3 vials \\
\hline 014670868 TACO263M & 8/18/09 19:34 & 3 & 46.1 & 23.6 & \\
\hline 014670868 TACO263R & 8/18/09 19:15 & 3 & 47.7 & 23.4 & \\
\hline 014670868 TACO263R & 8/18/09 19:49 & 1 & 35.4 & 19.4 & \\
\hline 014670869 TACO260M & $8 / 18 / 0911: 30$ & 1 & ND & 78.7 & \\
\hline 014670869 TACO260M & 8/18/09 19:00 & 1 & 27.6 & 49.5 & \\
\hline 014670869 TACO260M & 8/18/09 19:20 & 1 & 31.5 & 40.2 & \\
\hline 014670869 TACO260M & $8 / 18 / 09$ 19:40 & 1 & 29.3 & 38.1 & \\
\hline
\end{tabular}


Table 2-2. Results of analyses for propane and methane gas in water samples collected on August 18, September 1, and September 3, 2009, Tacony/Frankford Creek, Philadelphia, Pa.-Continued

$[\mu \mathrm{g} / \mathrm{L}$, micrograms per liter; $\mathrm{ND}$, not detected]

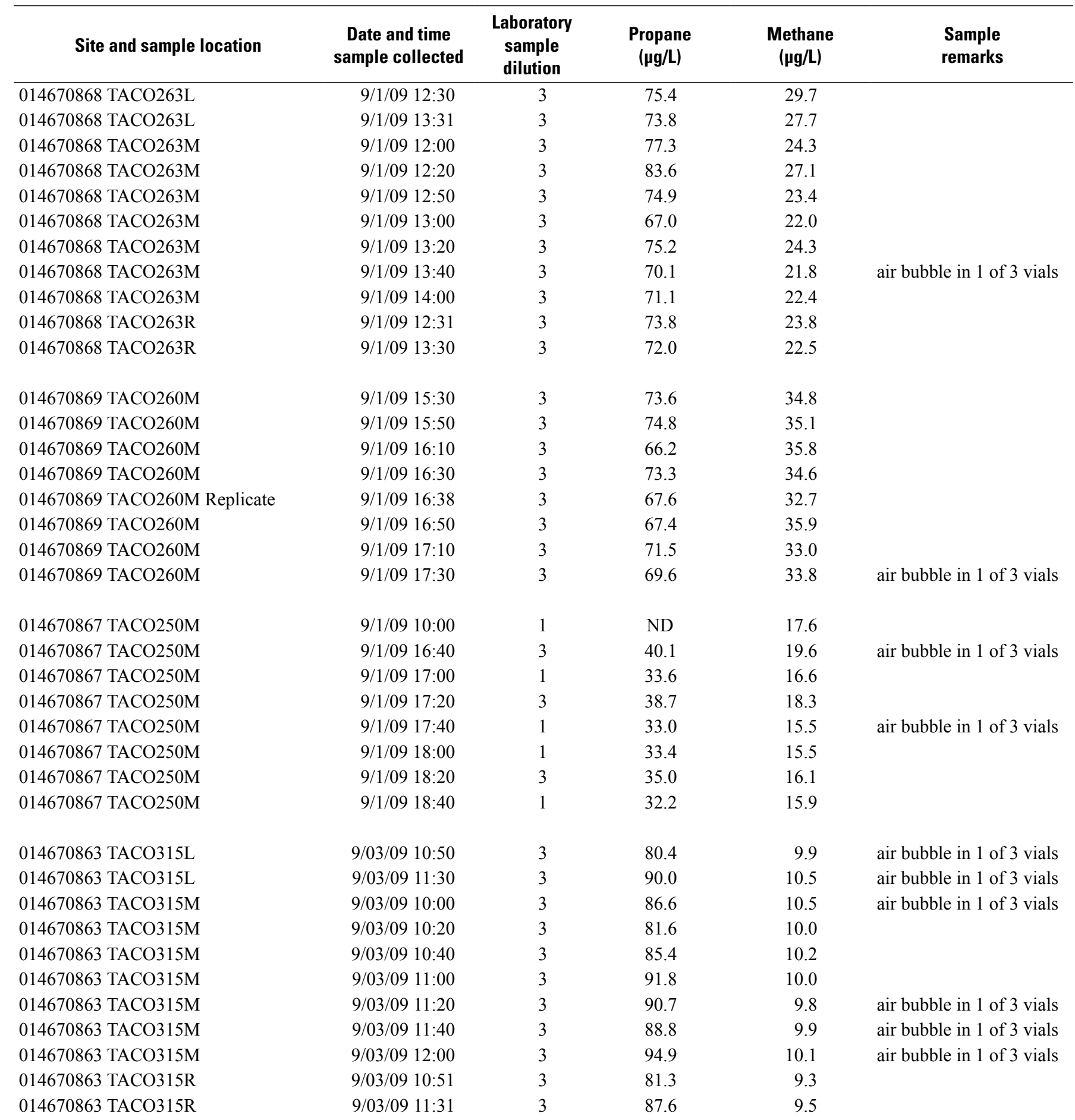


Table 2-2. Results of analyses for propane and methane gas in water samples collected on August 18, September 1, and September 3, 2009, Tacony/Frankford Creek, Philadelphia, Pa.—Continued

$[\mu \mathrm{g} / \mathrm{L}$, micrograms per liter; ND, not detected]

\begin{tabular}{lccccc}
\hline \multicolumn{1}{c}{ Site and sample location } & $\begin{array}{c}\text { Date and time } \\
\text { sample collected }\end{array}$ & $\begin{array}{c}\text { Laboratory } \\
\text { sample } \\
\text { dilution }\end{array}$ & $\begin{array}{c}\text { Propane } \\
\text { ( } \mathbf{\mu g} / \mathbf{L})\end{array}$ & $\begin{array}{c}\text { Methane } \\
\text { ( } \mathbf{g} / \mathbf{L})\end{array}$ & $\begin{array}{c}\text { Sample } \\
\text { remarks }\end{array}$ \\
\hline 014670864 TACO285M & $9 / 03 / 0916: 00$ & 1 & 28.9 & 6.6 & air bubble in 1 of 3 vials \\
014670864 TACO285M & $9 / 03 / 0916: 20$ & 1 & 29.2 & 6.9 & \\
014670864 TACO285M & $9 / 03 / 0916: 40$ & 3 & 33.2 & 8.3 & \\
014670864 TACO285M & $9 / 03 / 0917: 00$ & 3 & 30.9 & 7.7 & \\
014670864 TACO285M Replicate & $9 / 03 / 0917: 08$ & 1 & 29.1 & 8.1 & \\
014670864 TACO285M & $9 / 03 / 0917: 20$ & 3 & 33.7 & 8.3 & \\
014670864 TACO285M & $9 / 03 / 0917: 40$ & 1 & 30.0 & 7.6 & \\
014670864 TACO285M & $9 / 03 / 0918: 00$ & 1 & 29.5 & 7.3 & \\
& & & & & \\
014670866 TACO275M & $9 / 03 / 0909: 10$ & 1 & ND & 15.6 & \\
014670866 TACO275M & $9 / 03 / 0918: 15$ & 1 & 23.9 & 13.8 & \\
014670866 TACO275M & $9 / 03 / 0918: 30$ & 1 & 24.3 & 14.5 & \\
014670866 TACO275M & $9 / 03 / 0918: 45$ & 1 & 19.6 & 12.5 & \\
014670866 TACO275M & $9 / 03 / 0919: 00$ & 1 & 24.1 & 15.0 & \\
014670866 TACO275M & $9 / 03 / 0919: 15$ & 1 & 24.9 & 14.3 & \\
014670866 TACO275M & $9 / 03 / 0919: 30$ & 3 & 28.5 & 15.6 & \\
\hline
\end{tabular}




\section{Appendix 3.-Gas Injection Rates}

Table 3-1. Injection rates of propane gas on August 18, September 1, and September 3, 2009, in Tacony/Frankford Creek, Philadelphia, $\mathrm{Pa}$. 
Table 3-1. Injection rates of propane gas on August 18, September 1, and September 3, 2009 in Tacony/Frankford Creek, Philadelphia, $\mathrm{Pa}$.

[psi, pounds per square inch]

\begin{tabular}{|c|c|c|c|c|c|}
\hline Date & Time & $\begin{array}{c}\text { Tank pressure } \\
\text { (psi) }\end{array}$ & $\begin{array}{l}\text { Valve pressure } \\
\text { (psi) }\end{array}$ & $\begin{array}{l}\text { Flowrate or } \\
\text { feed pressure } \\
\text { (psi) }\end{array}$ & $\begin{array}{c}\text { Remarks on } \\
\text { flow rate }\end{array}$ \\
\hline \multicolumn{6}{|c|}{ August 18, 2009 - gas diffusers set at 06:30, dye injected 07:12 } \\
\hline $8 / 18 / 2009$ & $9: 25$ & 120 & 44 & 30 & \\
\hline $8 / 18 / 2009$ & $10: 25$ & 120 & 44 & 30 & \\
\hline $8 / 18 / 2009$ & $11: 30$ & 120 & 44 & 30 & \\
\hline $8 / 18 / 2009$ & $12: 30$ & 120 & 44 & 30 & \\
\hline $8 / 18 / 2009$ & $13: 15$ & 130 & 44 & 30 & \\
\hline $8 / 18 / 2009$ & $14: 36$ & 130 & 44 & 30 & \\
\hline $8 / 18 / 2009$ & $16: 44$ & 110 & 44 & 30 & \\
\hline $8 / 18 / 2009$ & $17: 26$ & 105 & 43 & 30 & \\
\hline \multicolumn{6}{|c|}{ September 1, 2009 - gas diffusers set at 06:45, dye injected 07:40 } \\
\hline $9 / 1 / 2009$ & $8: 35$ & 58 & 40 & 25 & ok \\
\hline $9 / 1 / 2009$ & $10: 00$ & 52 & 40 & 25 & ok \\
\hline $9 / 1 / 2009$ & $10: 51$ & 51 & 40 & 25 & ok \\
\hline $9 / 1 / 2009$ & $11: 25$ & 50 & 40 & 25 & ok \\
\hline $9 / 1 / 2009$ & $12: 11$ & 49 & 38 & 24 & ok \\
\hline $9 / 1 / 2009$ & $12: 55$ & 49 & 37 & 24 & ok \\
\hline $9 / 1 / 2009$ & $14: 00$ & 45 & 36 & 23 & ok \\
\hline $9 / 1 / 2009$ & $14: 45$ & 40 & 34 & 21 & ok \\
\hline $9 / 1 / 2009$ & $16: 06$ & 35 & 28 & 18 & ok \\
\hline $9 / 1 / 2009$ & $16: 38$ & 33 & 28 & 17 & slowing \\
\hline $9 / 1 / 2009$ & $17: 50$ & 20 & 22 & 15 & slowing \\
\hline \multicolumn{6}{|c|}{ September 3, 2009 - gas diffusers set at 06:15, dye injected 06:55 } \\
\hline $9 / 3 / 2009$ & $6: 50$ & 95 & 90 & 23 & \\
\hline $9 / 3 / 2009$ & $7: 30$ & 90 & 40 & 23 & \\
\hline $9 / 3 / 2009$ & $8: 00$ & 85 & 40 & 23 & \\
\hline $9 / 3 / 2009$ & $8: 30$ & 83 & 40 & 20 & \\
\hline $9 / 3 / 2009$ & $9: 30$ & 81 & 40 & 20 & \\
\hline $9 / 3 / 2009$ & 9:00 & 80 & 40 & 20 & \\
\hline $9 / 3 / 2009$ & $10: 00$ & 80 & 40 & 20 & \\
\hline $9 / 3 / 2009$ & $10: 30$ & 80 & 40 & 20 & \\
\hline $9 / 3 / 2009$ & $11: 00$ & 80 & 40 & 20 & \\
\hline $9 / 3 / 2009$ & $11: 29$ & 80 & 40 & 20 & \\
\hline $9 / 3 / 2009$ & $11: 59$ & 80 & 40 & 20 & \\
\hline $9 / 3 / 2009$ & $12: 29$ & 80 & 40 & 20 & \\
\hline $9 / 3 / 2009$ & $12: 59$ & 82 & 40 & 20 & \\
\hline $9 / 3 / 2009$ & $13: 29$ & 85 & 40 & 20 & \\
\hline $9 / 3 / 2009$ & $13: 59$ & 88 & 40 & 20 & \\
\hline $9 / 3 / 2009$ & $14: 29$ & 90 & 40 & 20 & \\
\hline $9 / 3 / 2009$ & $14: 59$ & 90 & 40 & 20 & \\
\hline $9 / 3 / 2009$ & $15: 29$ & 92 & 40 & 20 & \\
\hline $9 / 3 / 2009$ & $15: 59$ & 95 & 40 & 20 & \\
\hline $9 / 3 / 2009$ & $16: 29$ & 95 & 40 & 20 & \\
\hline $9 / 3 / 2009$ & $16: 59$ & 92 & 40 & 20 & \\
\hline $9 / 3 / 2009$ & $17: 29$ & 90 & 40 & 20 & \\
\hline
\end{tabular}


Prepared by the West Trenton Publishing Service Center.

For more information concerning this report, contact:

Director

U.S. Geological Survey

Pennsylvania Water Science Center

215 Limekiln Road

New Cumberland, PA 07070

dc_pa@usgs.gov

or visit our Web site at:

http://pa.water.usgs.gov 


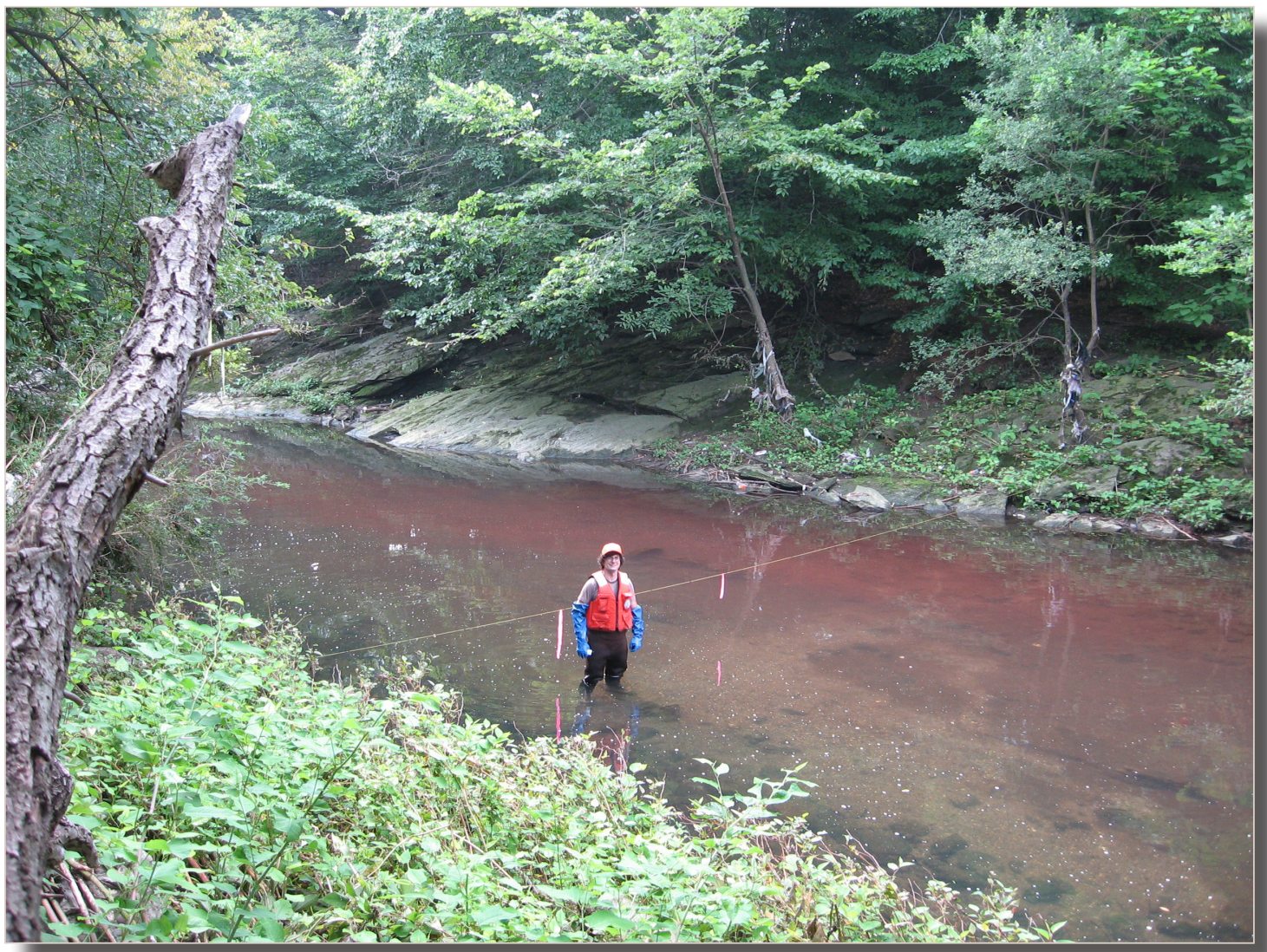

